\title{
Divergent Access to (1,1) and (1,2)-Azidolactones from Alkenes using Hypervalent Iodine Reagents
}

\author{
Sébastien Alazet, Franck Le Vaillant, Stefano Nicolai, Thibaut Courant and Jerome Waser ${ }^{[*]}$ \\ Dedication
}

\begin{abstract}
A versatile synthesis of azidolactones through azidation and cyclization of carboxylic acids onto alkenes has been developed. Based on either photoredox or palladium catalysis, $(1,1)$ and $(1,2)$ azido lactones can be selectively synthesized. The choice of catalyst and benziodoxol(on)e reagent serving as azide source was essential to initiate either a radical or Lewis Acid mediated process with divergent outcome. These transformations were carried out under mild conditions using a low catalyst loading and gave access to a large scope of azido lactones.
\end{abstract}

Amino lactones have found widespread applications in natural product synthesis and in medicinal chemistry. ${ }^{[1]}$ Furthermore, they serve as versatile starting materials for accessing other important building blocks, such as amino alcohols. ${ }^{[2]}$ As non-basic precursors of amines, azides are highly useful synthetic intermediates on the way to nitrogen-rich compounds. They can also be transformed easily into various other nitrogen-containing functional groups. ${ }^{[3]}$ Therefore, azidolactones are versatile and convenient precursors of both amino lactones and alcohols. Nevertheless, the preparation of azidolactones is usually based on multi-step protocols and lacks efficiency. The installation of the azido group commonly proceeds through substitution reactions on pre-functionalized substrates, such as halides. ${ }^{[4]}$ Very recently, a copper catalyzed enantioselective radical azidocarboxylation of alkenes was developed by Buchwald and co-workers using phenyliodine diacetate (PIDA) and $\mathrm{TMSN}_{3}$ as azide source, giving access to $(1,2)$-azidolactones 2 (Scheme $1, \mathbf{A}){ }^{[5]}$ However, this method is based on the in situ formation of highly reactive and potentially explosive hypervalent iodine reagents for the generation of the needed azide radical. Furthermore, this approach is limited to the synthesis of $(1,2)$-azidolactones: access to the $(1,1)$ regioisomers, if possible from the same starting materials, would be highly attractive to extend the range of accessible azidolactones. $(1,1)$ Azidolactones are a largely unexplored class of compounds, which have been reported only rarely in the literature. ${ }^{[6]}$

In recent years, benziodoxol(on)es, a class of stable cyclic hypervalent iodine reagents, have emerged as privileged reagents

$\left[{ }^{\star}\right] \quad$ Dr. S. Alazet, F. Le Vaillant, Dr. S. Nicolai, Dr. T. Courant[ $\left.{ }^{+}\right]$and Prof. Dr. J. Waser

Laboratory of Catalysis and Organic Synthesis

Ecole Polytechnique Fédérale de Lausanne

EPFL SB ISIC LCSO, BCH 4306, 1015 Lausanne (CH) Fax: (+)4121 6939700

E-mail: ierome.waser@epfl.ch

[+] Current address: Laboratoire COBRA - Bâtiment IRCOF UMR 6014 CNRS-INSA- Université de Rouen 1 ,

Rue Tesnière, 76281 Mont-Saint-Aignan Cedex (France)

Supporting information for this article is given via a link at the end of the document. for the transfer of functional groups via non-conventional reactivity. ${ }^{[7]}$ AzidoBenziodoXolone (ABX, 3a) and AzidoDimethyl-BenziodoXole (ADBX, 3b) (Scheme 1) have been first described by Zhdankin and co-workers ${ }^{[8]}$ and are stable solids decomposing at temperature higher than $100{ }^{\circ} \mathrm{C} .{ }^{[9]}$ They have been used as azide transfer reagents in presence of metal catalysts, relying either on radical-based ${ }^{[8,10]}$ or Lewis-acid mediated pathways. ${ }^{[1]}$ In particular, the azidation of styrene-type double bonds has recently attracted much interest and $\mathrm{ABX}$ (3a) and ADBX (3b) have emerged as good sources of azide radicals under reductive conditions. ${ }^{[10 a, h, j, 1]}$ In 2015, Greaney and co-workers reported the photoredox-catalyzed nucleoazidation of styrenes using the Sauvage/McMillin catalyst $\mathrm{Cu}(\mathrm{dap})_{2} \mathrm{Cl}^{[12]}$ and $\mathrm{ABX}$ reagent $3 \mathbf{a}$, resulting in particularly mild reaction conditions. ${ }^{[10 \mathrm{~h}]}$ On the other hand, the azidation of ketoesters and silyl enol ethers has been successful in the presence of Lewis acids. ${ }^{[1]}$ Nevertheless, to the best of our knowledge, azidobenziodoxol(on)es have never been used in the synthesis of azidolactones.

A) Buchwald Synthesis of (1,2)-Azidolactones

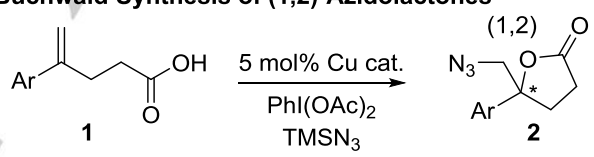

- Generation of an unstable reagent in situ

- Only 1,2-azidolactones

B) Our work: Divergent Synthesis of $(1,1)$ - and $(1,2)$-Azidolactones

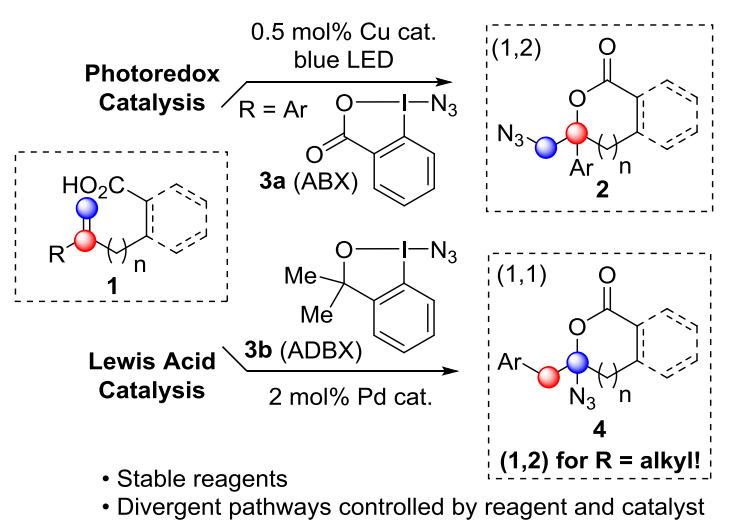

Scheme 1. Synthesis of Azidolactones from Alkenes.

Herein, we report the first synthesis of azidolactones based on the use of azidobenziodoxol(on)es (Scheme 1, B). The diverging behavior of $\mathrm{ABX}(\mathbf{3 a})$ and $\mathrm{ADBX}(\mathbf{3 b})$ in presence of metal catalysts led to either a radical-based or Lewis Acid mediated pathway, allowing the selective formation of $(1,2)$ - or $(1,1)-$ azidolactones $\mathbf{2}$ and $\mathbf{4}$ starting from styrene derivatives. The former was achieved under mild photoredox conditions using visible light irradiation and only $0.5 \mathrm{~mol} \% \mathrm{Cu}(\text { dap })_{2} \mathrm{Cl}$ as catalyst, 
whereas the later was realized by Lewis acid activation of the hypervalent iodine reagent, involving an aryl migration step. Furthermore, the synthesis of $(1,2)$-azidolactones starting from olefins without arene substituent was possible using Lewis acid activation.

Based on the impressive work of Greaney and co-workers, ${ }^{[10 \mathrm{~h}]}$ we started our investigations with the photoredox catalysis strategy for the formation of $(1,2)$-azidolactone $\mathbf{2}$ from unsaturated carboxylic acid 1 (Scheme 2). Only ABX (3a) was successful in this transformation. Upon a fine adjustment of the reaction conditions, ${ }^{[13]}$ the desired azidolactone 2 a could be isolated in $81 \%$ yield with $0.5 \mathrm{~mol} \%$ of the photoredox catalyst under blue LED irradiation. Interestingly, while the reaction also worked in the absence of light, conversion to product 2 a dropped to $20 \%$. This indicated that a radical chain process was possible, but less efficient. Using the combination of PIDA and $\mathrm{TMSN}_{3}$ for azide radical formation, ${ }^{[5]}$ only traces of $\mathbf{2 a}$ were detected.

With this simple protocol for azidation in hands, we investigated the scope of the reaction (Scheme 2). A broad series of unsaturated carboxylic acids $\mathbf{1}$ containing substituted aryl groups was converted into the corresponding azidolactones $\mathbf{2}$ in good to excellent yields. Electron rich $(\mathbf{2 b}, \mathbf{2 c})$ as well as halogensubstituted arenes (2d-f) were well tolerated. A more rigid benzene backbone led to excellent yields of $(1,2)$-azido-phthalide

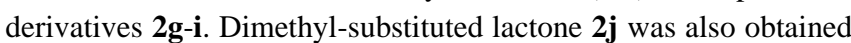
in $90 \%$ yield. A thiophene heterocycle was compatible with the reaction conditions $(\mathbf{2} \mathbf{k}, 87 \%)$. An aromatic ring bearing a group in the ortho position was also tolerated (2l, 71\%). Tricyclic $(1,2)$ azido- $\gamma$-butyrolactone $\mathbf{2 m}$ was obtained in $65 \%$ yield. When enoic acid 1 n containing a 1,3-enyne motif was used, azidation product 2n was formed in $47 \%$ yield. Importantly, $(1,2)$-azido- $\delta$-lactones could be also obtained under the same reaction conditions, although lower yields were observed (product 2o-q). Scale up of the reaction demonstrated that even lower catalyst loadings were possible: $1.0 \mathrm{~g}$ of $2 \mathrm{e}$ was isolated in $82 \%$ yield using only 0.05 mol\% catalyst.

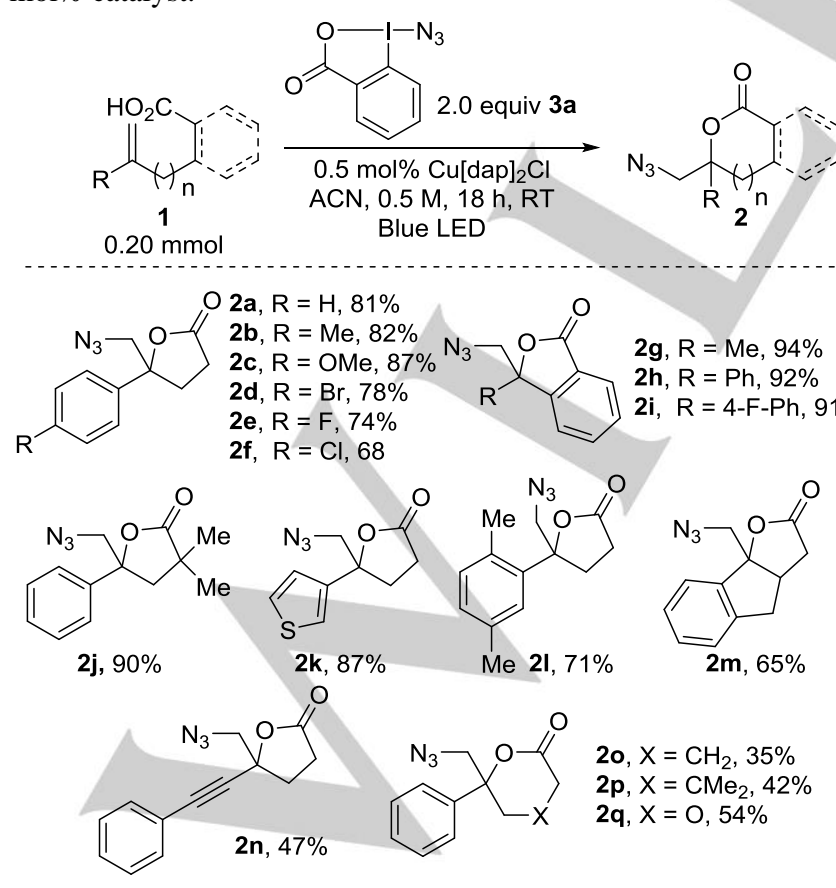

Scheme 2. Scope of the (1,2)-azidolactonization.
In contrast, when ADBX (3b) was used instead of ABX (3a) under the optimized photoredox conditions, only traces of $(1,2)$-azido- $\gamma$ butyrolactones 2a were observed. The major product was 4-oxo-5phenylpentanoic acid (5), which was isolated in $40 \%$ yield. (Equation 1) We speculated that $\mathbf{5}$ could originate from the hydrolysis of a $(1,1)$-azidolactone $\mathbf{4 a}$ formed from reaction of the hypervalent iodine reagent with the double bond followed by 1,2phenyl migration. In fact, such rearrangements have been observed for oxygenation or fluorination, ${ }^{[14]}$ but are unprecedented for azidation with benziodoxole reagents. In this case, the copper catalyst probably acted as a Lewis acid to activate ADBX (3b) and not as a redox active catalyst able to generate the azide radical after a SET event.

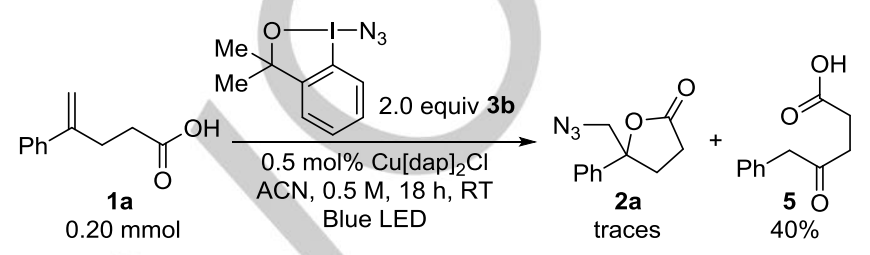

Equation 1. Reaction of $1 \mathbf{a}$ with $\mathrm{ADBX}(\mathbf{3 b})$.

In fact, in presence of several Lewis acid catalysts such as $\mathrm{Zn}(\mathrm{OTf})_{2}, \operatorname{In}(\mathrm{OTf})_{3}$ and $\mathrm{Sn}(\mathrm{OTf})_{2},(1,1)$-azidolactone $4 \mathbf{a}$ could be isolated as the major product. ${ }^{[13]} \mathrm{Pd}(\mathrm{hfacac})_{2} \quad(2 \mathrm{~mol} \%)$ was identified as the best catalyst for this transformation leading to 4 in $75 \%$ yield by NMR. Sn(OTf $)_{2}$ provided similar results, but with lower reproducibility. The low catalyst loading is noteworthy, as most reported oxidative rearrangements required stoichiometric amounts of Lewis or Brønsted acids. ${ }^{[14]}$ Although $4 \mathbf{a}$ was sensitive to hydrolysis, it was still possible to purify it by column chromatography (52\% pure $\mathbf{4 a}$ isolated).
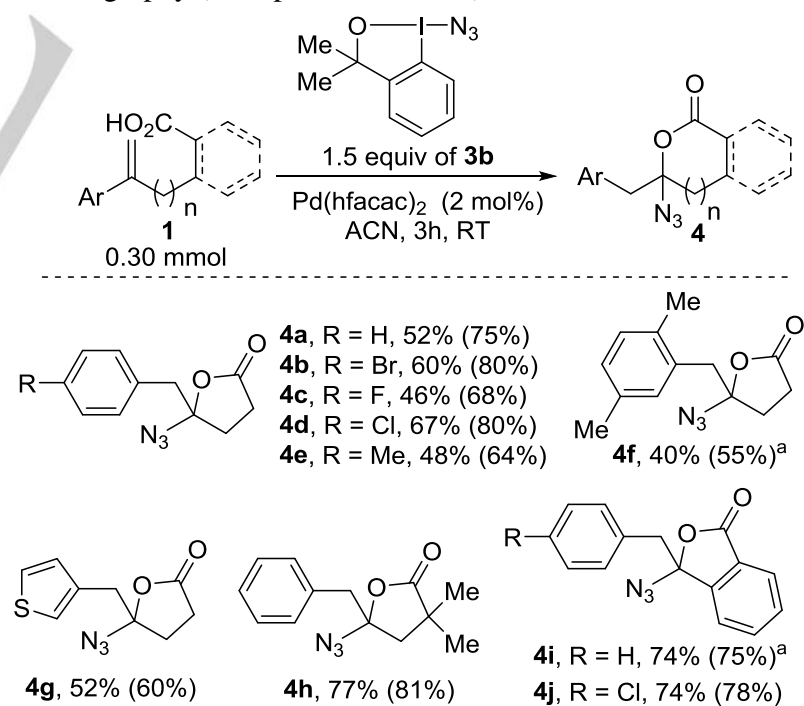

$4 \mathrm{j}, \mathrm{R}=\mathrm{Cl}, 74 \%(78 \%)$

4k, $R=F, 60 \%(75 \%)^{a}$

Scheme 3. Scope of $(1,1)$-azidolactonization of 1. (isolated yield given, NMR yield in brackets). a) Isolated as a mixture with 2-(2iodophenyl)propan-2-ol.

The reaction worked efficiently in the presence of halogen and methyl substituents on the aromatic ring, affording products $\mathbf{4 b - f}$ in $55-80 \%$ yield. A thiophenyl group was also able to migrate, affording $\mathbf{4 g}$ in $52 \%$ isolated yield. A geminal dimethyl substituted substrate $\mathbf{1 h}$ gave the more stable azido lactone $\mathbf{4 h}$ in $77 \%$ isolated 
yield. Finally, (1,1)-azido-phthalide derivatives $\mathbf{4 i}, \mathbf{4 j}, \mathbf{4 k}$ were also generated in high yields.

Due to the high sensitivity of the obtained $(1,1)$-azidolactones, the direct modification of the crude products was then investigated (Scheme 4). Copper catalyzed cycloaddition starting from $\mathbf{4 k}$ and phenylacetylene gave triazole $\mathbf{6}$ as a stable crystalline solid in $65 \%$ yield over two steps starting from the olefin. Hydrogenation of the crude reaction mixture containing $\mathbf{4 a}$ in EtOAc, using $5 \mathrm{~mol} \%$ of $\mathrm{Pd} / \mathrm{C}$, afforded ketone $\mathbf{5}$ in $75 \%$ yield over two steps. ${ }^{[15]}$ The $\gamma$ ketoester could be selectively generated through the hydrogenation of the crude material of $\mathbf{4 a}$ in methanol in $70 \%$ yield over two steps. When using $10 \mathrm{~mol} \%$ of Pt black as catalyst with $(1,1)$ azido- $\gamma$-butyrolactone $4 \mathbf{d}$ in the presence of $\mathrm{Boc}_{2} \mathrm{O}$, the N-Boc protected Gamma AminoButyric Acid (GABA) derivative 8 was isolated in $48 \%$ yield. The GABA motif is commonly found in many bioactive compounds and is an important target in synthetic chemistry. ${ }^{[16]}$ In the case of $(1,1)$-azido-phthalide derivative $\mathbf{4 k}$, only azide reduction was observed under $\mathrm{Pt} / \mathrm{C}$ catalysis and the $(1,1)$-amino-phthalide 9 was isolated in $80 \%$ yield. These successful transformations demonstrated the potential of $(1,1)$ azidolactones as useful building blocks.

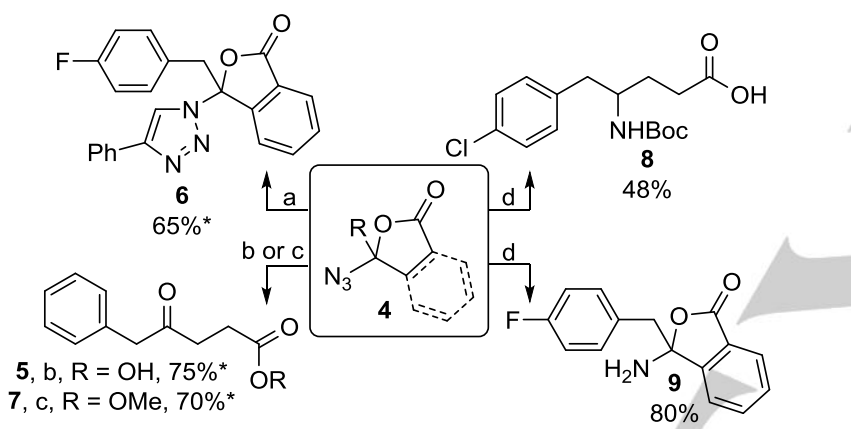

Scheme 4. Product modifications. *Isolated yields over two steps from 1. Reaction conditions: a) $\mathrm{Cul}(10 \mathrm{~mol} \%), \mathrm{Et}_{3} \mathrm{~N}$ (3.0 equiv.), phenylacetylene (2.0 equiv.), THF, $25^{\circ} \mathrm{C}$; b) $\mathrm{H}_{2}, \mathrm{Pd} / \mathrm{C}(5 \mathrm{~mol} \%)$, EtOAc, $25^{\circ} \mathrm{C}$; c) $\mathrm{H}_{2}, \mathrm{Pd} / \mathrm{C}(2.5 \mathrm{~mol} \%), \mathrm{MeOH}, 25^{\circ} \mathrm{C}$; d) $\mathrm{H}_{2}$, Pt black (10 mol\%), $\mathrm{Boc}_{2} \mathrm{O}\left(2.0\right.$ equiv.), THF, $25^{\circ} \mathrm{C}$

In order to investigate the generality of the 1,2-shift, we then replaced the aryl substituent by a simple alkyl group (Scheme 5). No $(1,1)$-azidolactone was obtained with a benzyl group: only traces of (1,2)-azidolactonization product $\mathbf{2} \mathbf{r}$ could be observed. 1,2-Azidolactone 2 s could be obtained in $40 \%$ with a phenyl group in $\gamma$ position to the alkene. Interestingly, compounds $2 \mathrm{~s}$ is not formed under photoredox conditions, as an aryl group on the alkene is required for oxidation of the carbon centered radical intermediate. Better yields were obtained with more rigid substrates derived from benzoic acid (products $2 \mathbf{g}$ and $\mathbf{2 t}-\mathbf{v}$ ). $\gamma$ lactone $\mathbf{2 g}$ can be synthesized in better yield under photoredox conditions, but $\delta$-lactone $2 \mathrm{t}-\mathbf{v}$ can be accessed only with Lewis acid catalysis, showing that the two methods are highly complementary. Based on the precedence in literature on radical and Lewis acid pathways with hypervalent iodine reagents, ${ }^{[10,14]}$ a speculative mechanism can be proposed for the developed transformations (Scheme 6). The better results obtained with $\mathrm{ABX}$ (3a) under photoredox conditions could be due to its expected stronger oxidant character when compared to $\operatorname{ADBX}(\mathbf{3 b}) .{ }^{[17]}$ In contrast, the Lewis acid catalytic cycle would be initiated by the activation of ADBX (1b) ${ }^{[18]}$ The resulting more electrophilic complex I will react with alkene $\mathbf{1}$ to give iodocyclopropylium cation II.
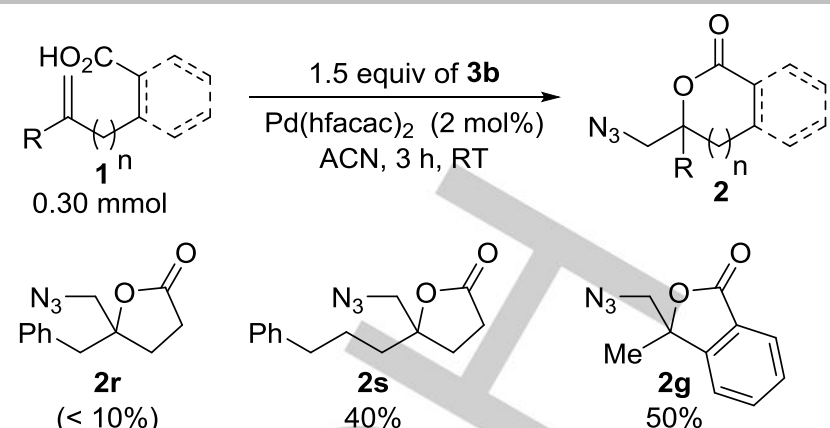<smiles>NCC1Cc2ccccc2C(=O)O1</smiles>

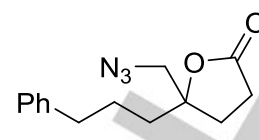

$2 s$ $40 \%$

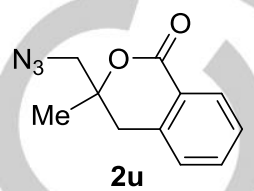

$72 \%$ a
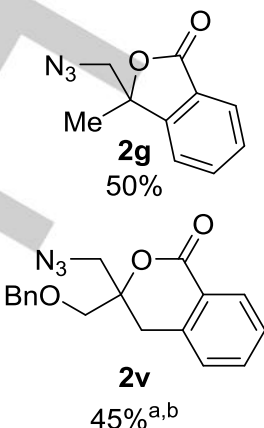

Scheme 5. Lewis acid catalyzed synthesis of $(1,2)$-azidolactones. a) $20 \mathrm{~h}$ of reaction. b) $10 \mathrm{~mol} \%$ of $\mathrm{Pd}(\text { hfacac })_{2}$ were used.

A proton transfer can also be expected from the carboxylic acid to the more basic alkoxide, a key step to promote catalyst turnover only possible with $\mathbf{3 b}$. Ring opening through the attack of the carboxylic acid delivers then the highly electrophilic intermediate III. In case of aliphatic substituents, direct substitution with the azide would occur, leading to $(1,2)$-azidolactones $\mathbf{2}$. In case of aryl substituents, 1,2-migration via a phenonium ion or a non-classical carbocation IV is faster and gives product 4a. Further works will be needed to support this speculative mechanism.

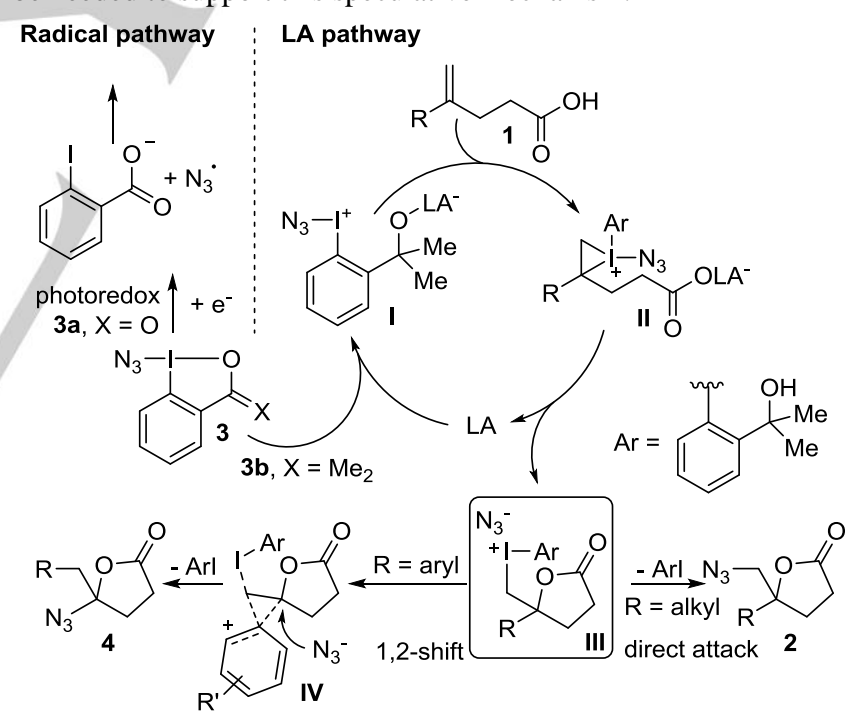

Scheme 6. Speculative reaction mechanism.

In conclusion, we have reported a general and versatile synthesis of azidolactones starting from alkene-containing carboxylic acids. A large range of $(1,1)$ and $(1,2)$-azidolactones were obtained selectively in high yields and with broad functional group tolerance. The fine modulation of the reactivity possible for benziodoxolone reagents was key to enable either a photoredox or a Lewis acid pathway to access $(1,1)$ - and $(1,2)$-azidolactones respectively. These results further establish the exceptional potential of cyclic hypervalent iodine reagents for group transfer reactions and will allow a broader use of azidolactones as useful building blocks in synthetic and medicinal chemistry. 


\section{Acknowledgements}

We thank ERC (European Research Council, Starting Grant iTools4MC, number 334840) and EPFL for financial support.

Keywords: Azides, lactones, hypervalent iodine, photoredox, 1,2 shift.

[1] a) G. Blaskó, D. J. Gula, M. Shamma, J. Nat. Prod. 1982, 45, 105; b) M. Bös, H. Stadler, J. Wichmann, F. Jenck, J. R. Martin, J.-L. Moreau, A. J. Sleight, Helv. Chim. Acta 1998, 81,525 ; c) C. Kaiser, C. J. Spagnuolo, T. C. Adams, V. H. Audia, A. C. Dupont, H. Hatoum, V. C. Lowe, J. C. Prosser, B. L. Sturm, L. Noronha-Blob, J. Med. Chem. 1992, 35 , 4415; d) Y. Shimojima, H. Hayashi, J. Med. Chem. 1983, 26 , 1370 .

[2] a) S. C. Bergmeier, Tetrahedron 2000, 56, 2561; b) T. J. Donohoe, C. K. A. Callens, A. Flores, A. R. Lacy, A. H. Rathi, Chem. Eur. J. 2011, 17, 58.

[3] S. Bräse, C. Gil, K. Knepper, V. Zimmermann, Angew. Chem. Int. Ed. 2005, 44, 5188 .

[4] a) Z. Ding, R. B. Silverman, J. Med. Chem. 1992, 35, 885; b) A. Gross, D. R. Borcherding, D. Friedrich, J. S. Sabol, Tetrahedron Lett. 2001, 42, 1631; c) D. Scarpi, L. Bartali, A. Casini, E. G. Occhiato, Eur. J. Org. Chem. 2013, 2013, 1306; d) R. Surmont, G. Verniest, J. W. Thuring, P. ten Holte, F. Deroose, N. De Kimpe, Org. Biomol. Chem. 2010, 8, 4514; e) C. K. Tan, C. Le, Y.-Y. Yeung, Chem. Commun. 2012, 48, 5793.

[5] R. Zhu, S. L. Buchwald, J. Am. Chem. Soc. 2015, 137, 8069.

[6] a) M. V. Bhatt, K. S. Rao, G. V. Rao, J. Org. Chem 1977, 42, 2697; b) R. Guilhemat, M. Pereyre, M. Petraud, Bull. Soc. Chim. Fr. 1980, 2, 334; c) H. Takeuchi, S. Eguchi, J. Chem. Soc., Perkin Trans. 1 1988, 2149.

[7] a) Y. Li, D. P. Hari, M. V. Vita, J. Waser, Angew. Chem. Int. Ed. 2016, 55, 4436; b) A. Yoshimura, V. V. Zhdankin, Chem Rev. 2016, 116, 3328 .

[8] a) V. V. Zhdankin, A. P. Krasutsky, C. J. Kuehl, A. J. Simonsen, J. K. Woodward, B. Mismash, J. T. Bolz, J. Am. Chem. Soc. 1996, 118, 5192; b) V. V. Zhdankin, M. McSherry, B. Mismash, J. T. Bolz, J. K. Woodward, R. M. Arbit, S. Erickson, Tetrahedron Lett. 1997, 38, 21; c) S. Akai, T. Okuno, M. Egi, T. Takada, H. Tohma, Y. Kita, Heterocycles 1996, 42, 47.

[9] M. V. Vita, J. Waser, Angew. Chem., Int. Ed. 2015, 54, 5290. Caution: Reagent 3a displays an explosive decomposition behaviour.

[10] a) B. Zhang, A. Studer, Org. Lett. 2013, 15, 4548; b) H. Yin, T. Wang, N. Jiao, Org. Lett. 2014, 16, 2302; c) Y. Fan, W. Wan, G. Ma, W. Gao, H. Jiang, S. Zhu, J. Hao, Chem. Comm 2014, 50, 5733; d) A. Sharma, J. F. Hartwig, Nature 2015, 517, 600; e) R. R. Karimov, A. Sharma, J. F. Hartwig, ACS Central Sci. 2016, 2, 715; f) N. Fuentes, W. Kong, L. Fernández-Sánchez, E. Merino, C. Nevado, J. Am. Chem. Soc. 2015, 137, 964; g) W. Kong, N. Fuentes, A. GarcíaDomínguez, E. Merino, C. Nevado, Angew. Chem. Int. Ed. 2015, 54, 2487; h) G. Fumagalli, P. T. G. Rabet, S. Boyd, M. F. Greaney, Angew. Chem. Int. Ed. 2015, 54, 11481; i) P. T. G. Rabet, G. Fumagalli, S. Boyd, M. F. Greaney, Org. Lett. 2016, 18, 1646; j) M.-Z. Lu, C.-Q. Wang, T.-P. Loh, Org. Lett. 2015, 17, 6110; k) Y. Shinomoto, A. Yoshimura, H. Shimizu, M. Yamazaki, V. V. Zhdankin, A. Saito, Org. Lett. 2015, 17, 5212; 1) Y.-A. Yuan, D.-F. Lu, Y.-R. Chen, H. Xu, Angew. Chem., Int. Ed. 2016, 55, 534; m) Y. Wang, G.-X. Li, G. Yang, G. He, G. Chen, Chem. Sci. 2016, 7, 2679; n) T. Yang, H. Zhu, W. Yu, Org. Biomol. Chem. 2016, 14, 3376; o) L. Li, Z. L. Li, F. L. Wang, Z. Guo, Y. F. Cheng, N. Wang,
X. W. Dong, C. Fang, J. J. Liu, C. H. Hou, B. Tan, X. Y. Liu, Nat. Commun. 2016, 7, 13852 .

[11] a) Q.-H. Deng, T. Bleith, H. Wadepohl, L. H. Gade, J. Am. Chem. Soc. 2013, 135, 5356; b) M. V. Vita, J. Waser, Org. Lett. 2013, 15, 3246; c) M. V. Vita, P. Caramenti, J. Waser, Org. Lett. 2015, 17, 5832;

[12] a) B. T. Ahn, D. R. McMillin, Inorg. Chem. 1978, 17, 2253 b) C. O. Dietrichbuchecker, P. A. Marnot, J. P. Sauvage, J. R. Kirchhoff, D. R. McMillin, J. Chem. Soc., Chem. Commun. 1983, 513 .

[13] See Supporting Information for a complete list of tested reaction conditions.

[14] Selected examples: a) A. C. Boye, D. Meyer, C. K. Ingison, A. N. French, T. Wirth, Org. Lett. 2003, 5, 2157; b) U. Farid, F. Malmedy, R. Claveau, L. Albers, T. Wirth, Angew. Chem., Int. Ed. 2013, 52, 7018; c) M. Brown, R. Kumar, J. Rehbein, T. Wirth, Chem. Eur. J. 2016, 22, 4030; d) N. O. Ilchenko, B O. A. Tasch, K. J. Szabó, Angew. Chem. Int. Ed. 2014, 53, 12897; e) J. Zhang, K. J. Szabó, F. Himo, ACS Catal. 2017, 7, 1093; f) G. C. Geary, E. G. Hope, A. M. Stuart, Angew. Chem., Int. Ed. 2015, 54, 14911; g) L. Liu, T. Zhang, Y.-F. Yang, D. Zhang-Negrerie, X. Zhang, Y. Du, Y.-D. Wu, K. Zhao, J. Org. Chem. 2016, 81, 4058; h) A. Ulmer, C. Brunner, A. M. Arnold, A. Pöthig, T. Gulder, Chem. Eur. J. 2016, 22, 3660; i) B. Zhou, T. Yan, X.-S. Xue, J.-P. Cheng, Org. Lett. 2016, 18, 6128; For a review, see: j) F. V. Singh, T. Wirth, Synthesis 2013, 45, 2499.

[15] In principle, a simple hydrolysis would also lead to the same compound. Nevertheless, better yields were obtained under hydrogenation conditions, probably because prior reduction of the azide facilitates hydrolysis under mild conditions.

[16] a) M. Ordonez, C. Cativiela, Tetrahedron-Asymmetry 2007 , 18, 3; b) P. G. Vasudev, S. Chatterjee, N. Shamala, P. Balaram, Chem. Rev. 2011, 111, 657.

[17] The oxidation potential of azidobenziodoxol(on)e is not yet known, but a similar trend as observed with Togni reagents can be expected: Y. Yasu, T. Koike, M. Akita, Angew. Chem., Int. Ed. 2012, 51, 9567.

[18] At this stage, a redox catalytic cycle involving different oxidation states of palladium cannot be excluded, but it appears less probable as several Lewis acids were able to catalyze the reactions. 


\section{Entry for the Table of Contents}

\section{COMMUNICATION}

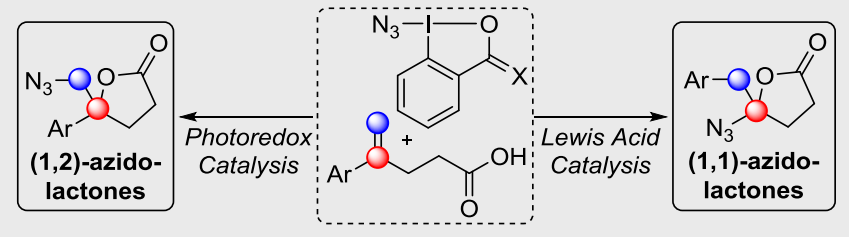

Sébastien Alazet, Franck Le Vaillant, Stéfano Nicolai, Thibaut Courant and Jerome Waser ${ }^{*}$

From one to both: A versatile synthesis of azidolactones from alkenes and carboxylic acids has been developed based on photoredox and palladium catalysis. $(1,1)$ and $(1,2)$-azido lactones can be selectively synthesized through the choice of benziodoxole reagent and catalyst. These transformations have been carried out under mild conditions using low catalyst loading and give access to a large scope of azidolactones.

\section{Page No. - Page No.}




\title{
Supporting Information
}

\author{
107 pages
}

\section{Table of Content}

1. General Methods $\quad$ S2

2. Synthesis of Hypervalent Iodine Reagents S3

3. Synthesis of Starting Materials

4. Photoredox Catalysis $\quad$ S24

5. Optimization for the Lewis-acid catalyzed cascade functionalization of alkenes S31

6. Lewis Acid Catalyzed Azidolactonization $\quad$ S33

7. Pd-Catalyzed Synthesis of (1,2)-Azidolactones $\quad$ S38

$\begin{array}{ll}\text { 8. Derivatizations } & \text { S41 }\end{array}$

9. Spectra of Compounds $\quad$ S44

$\begin{array}{ll}\text { 10. References } & \text { S107 }\end{array}$ 


\section{General Methods}

All reactions were carried out in oven dried glassware under an atmosphere of nitrogen, unless stated otherwise. For quantitative flash chromatography technical grade solvents were used. For flash chromatography for analysis, HPLC grade solvents from Sigma-Aldrich were used. THF, $\mathrm{Et}_{2} \mathrm{O}, \mathrm{CH}_{3} \mathrm{CN}$, toluene, hexane and $\mathrm{CH}_{2} \mathrm{Cl}_{2}$ were dried by passage over activated alumina under nitrogen atmosphere $\left(\mathrm{H}_{2} \mathrm{O}\right.$ content $<10 \mathrm{ppm}$, Karl-Fischer titration). $\mathrm{NEt}_{3}$ and pyridine were distilled under nitrogen from $\mathrm{KOH}$. The solvents were degassed by Freeze-Pump-Thaw method when mentioned. All chemicals were purchased from Acros, Aldrich, Fluka, VWR, Aplichem or Merck and used as such unless stated otherwise. Chromatographic purification was performed as flash chromatography using Macherey-Nagel silica 40-63, $60 \AA$, using the solvents indicated as eluent with 0.1-0.5 bar pressure. TLC was performed on Merck silica gel $60 \mathrm{~F}_{254}$ TLC glass plates or aluminium plates and visualized with UV light, permanganate stain, CAN stain or Anisaldehyde stain or Seebach stain (Phosphomolybdid acid, $\mathrm{Ce}\left(\mathrm{SO}_{4}\right)_{2}, \mathrm{H}_{2} \mathrm{SO}_{4}$, water). Melting points were measured on a Büchi B-540 melting point apparatus using open glass capillaries, the data is uncorrected. ${ }^{1} \mathrm{H}-\mathrm{NMR}$ spectra were recorded on a Brucker DPX-400 $400 \mathrm{MHz}$ spectrometer in chloroform-d, DMSO- $\mathrm{d}_{6}$ or $\mathrm{CD}_{3} \mathrm{OD}$, all signals are reported in ppm with the internal chloroform signal at $7.26 \mathrm{ppm}$, the internal DMSO signal at $2.50 \mathrm{ppm}$ or the internal methanol signal at $3.30 \mathrm{ppm}$ as standard. The data is being reported as $(\mathrm{s}=$ singlet, $\mathrm{d}=$ doublet, $\mathrm{t}=$ triplet, $\mathrm{q}=$ quadruplet, $\mathrm{qi}=$ quintet, $\mathrm{m}=$ multiplet or unresolved, $\mathrm{br}=$ broad signal, $\mathrm{app}=$ apparent, coupling constant(s) in $\mathrm{Hz}$, integration, interpretation) ${ }^{13} \mathrm{C}-\mathrm{NMR}$ spectra were recorded with ${ }^{1} \mathrm{H}$-decoupling on a Brucker DPX-400 $100 \mathrm{MHz}$ spectrometer in chloroform-d, DMSO- $\mathrm{d}_{6}$ or $\mathrm{CD}_{3} \mathrm{OD}$, all signals are reported in ppm with the internal chloroform signal at $77.0 \mathrm{ppm}$, the internal DMSO signal at $39.5 \mathrm{ppm}$ or the internal methanol signal at $49.0 \mathrm{ppm}$ as standard. Infrared spectra were recorded on a JASCO FT-IR B4100 spectrophotometer with an ATR PRO410-S and a ZnSe prisma and are reported as $\mathrm{cm}^{-1}(\mathrm{w}=$ weak, $\mathrm{m}=$ medium, $\mathrm{s}=$ strong, $\mathrm{br}$ $=$ broad). High resolution mass spectrometric measurements were performed by the mass spectrometry service of ISIC at the EPFL on a MICROMASS (ESI) Q-TOF Ultima API. High resolution mass spectrometric measurements were performed by the mass spectrometry service of ISIC at the EPFL on a MICROMASS (ESI) Q-TOF Ultima API. Reactions were performed in test tubes $(1.0$ to $10 \mathrm{~mL})$ which were hold using a rack for test tubes placed at the center of a crystallization flask, the latter was continuously flushed with air in order to keep the temperature as constant as possible. On this flask were attached the blue LEDs (RUBAN LED 5MÈTRES 60LED/M - 3528 BLEU - IP65 with Transformateur pour Ruban LED 24W/2A/12V, bought directly on RubanLED.com). The distance between the LEDs and the test tubes was approximatively $3 \mathrm{~cm}$. Temperature ranged between 25 and $30{ }^{\circ} \mathrm{C}$, and long irradiation resulted in temperature increasing up to $34{ }^{\circ} \mathrm{C}$ during overnight reactions. $\mathrm{Cu}[\mathrm{dap}]_{2} \mathrm{Cl}$ complex was purchased from Sigma-Aldrich and used as received. 


\section{Synthesis of Hypervalent Iodine Reagents}

\section{a. Synthesis of 1-azido-1,2-benziodoxole-3-(1H)-one (3a)}

\section{1-Hydroxy-1,2-benziodoxol-3-(1H)-one (11)}<smiles>O=C(O)c1ccccc1I</smiles>

10

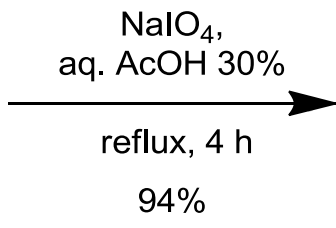

$94 \%$<smiles>O=C1OI(O)c2ccccc21</smiles>

11

$\mathrm{NaIO}_{4}$ (7.24 g, $33.8 \mathrm{mmol}, 1.00$ equiv) and 2-iodo benzoic acid (10) (8.00 g, $32.2 \mathrm{mmol}, 1.00$ equiv) were suspended in $30 \%(\mathrm{v}: \mathrm{v})$ aq $\mathrm{AcOH}(48 \mathrm{~mL})$ under air. The mixture was vigorously stirred and refluxed for $4 \mathrm{~h}$. the reaction mixture was then diluted with cold water $(180 \mathrm{~mL})$ and allowed to cool to room temperature, protecting it from light. The mixture is then filtered and further washed with ice water and cold acetone, air dried in the dark overnight to give the pure compound 11 (8.14 g, $30.4 \mathrm{mmol}, 94 \%)$ as a colorless solid. ${ }^{\mathbf{1}} \mathbf{H}$ NMR $\left(400 \mathrm{MHz},\left(\mathrm{CD}_{3}\right)_{2} \mathrm{SO}\right)$ $8.02(\mathrm{dd}, J=7.7,1.4 \mathrm{~Hz}, 1 \mathrm{H}, \mathrm{ArH}), 7.97(\mathrm{~m}, 1 \mathrm{H}, \mathrm{ArH}), 7.85(\mathrm{dd}, J=8.2,0.7 \mathrm{~Hz}, 1 \mathrm{H}, \mathrm{ArH}), 7.71$ $(\mathrm{td}, J=7.6,1.2 \mathrm{~Hz}, 1 \mathrm{H}, \mathrm{ArH}) .{ }^{13} \mathrm{C}$ NMR (100 MHz, $\left.\left(\mathrm{CD}_{3}\right)_{2} \mathrm{SO}\right) 167.7,134.5,131.5,131.1$, 130.4, 126.3, 120.4. IR $3083(\mathrm{w}), 3060$ (w), 2867 (w), 2402 (w), 1601 (m), 1585 (m), $1564(\mathrm{~m})$, 1440 (m), 1338 (s), 1302 (m), 1148 (m), 1018 (w), 834 (m), 798 (w), 740 (s), 694 (s), 674 (m), $649(\mathrm{~m})$. NMR data correspond to the reported values. ${ }^{[1]}$

\section{1-Acetoxy-1,2-benziodoxol-3-(1H)-one (12)}<smiles>O=C1OI(O)c2ccccc21</smiles>

11

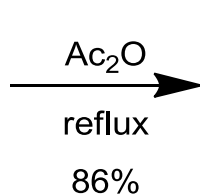

$86 \%$<smiles>CC(=O)OI1C(=O)OC1=O</smiles>

12

Following a reported procedure, ${ }^{[2]}$ compound 11 (3.00 g, $11.3 \mathrm{mmol}, 1.00$ equiv) was heated in $\mathrm{Ac}_{2} \mathrm{O}(10 \mathrm{~mL})$ to reflux until the solution turned clear (without suspension). The mixture was then left to cool down and white crystals started to form. The crystallization was continued at -18 ${ }^{\circ} \mathrm{C}$. The crystal were then collected and dried overnight under high vacuum to give compound 12 (3.06 g, $10.0 \mathrm{mmol}, 86 \%) .{ }^{1} \mathbf{H}$ NMR (400 MHz, $\left.\mathrm{CDCl}_{3}\right) \delta 8.25(\mathrm{dd}, J=7.6,1.4 \mathrm{~Hz}, 1 \mathrm{H}, \mathrm{Ar} H)$, $8.00(\mathrm{dd}, J=8.3,0.5 \mathrm{~Hz}, 1 \mathrm{H}, \operatorname{Ar} H), 7.92(\mathrm{dt}, J=7.0,1.7 \mathrm{~Hz}, 1 \mathrm{H}, \mathrm{Ar} H), 7.71(\mathrm{td}, J=7.6,0.9 \mathrm{~Hz}$, $1 \mathrm{H}, \mathrm{ArH}), 2.25\left(\mathrm{~s}, 3 \mathrm{H}, \mathrm{COCH}_{3}\right)$. NMR data correspond to the reported values. ${ }^{[2]}$

\section{1-Azido-1,2-benziodoxole-3-(1H)-one (3a)}<smiles>CC(=O)OI1OC(=O)c2ccccc21</smiles>

12

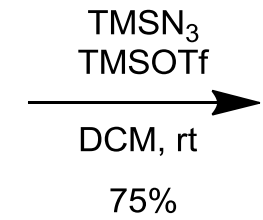

$75 \%$<smiles></smiles>

3a

Caution: reaction carried out behind a safety shield! Following a reported procedure, ${ }^{[3]}$ compound 12 (1.00 g, 3.28 mmol, 1.00 equiv) was stirred in dry DCM (3 m) then TMSN $_{3}(0.66$ 
$\mathrm{mL}, 4.9$ mmol, 1.5 equiv) was cautiously added. A catalytic amount of TMSOTf (3 $\mu \mathrm{L}, 0.02$ mmol, 0.005 equiv) was added last to the mixture which was then stirred for 30 minutes. The reaction mixture was then died in vacuo to give a yellow precipitate, which was washed a few times with hexanes to give compound $\mathbf{3 a}(0.70 \mathrm{~g}, 2.4 \mathrm{mmol}, 74 \%)$ as a pure pale yellow crystal. ${ }^{1}$ H NMR (400 MHz, $\left.\mathrm{CDCl}_{3}: \mathrm{CH}_{3} \mathrm{CN} ; 10: 1\right) \delta 8.17(\mathrm{dd}, J=7.5,1.3 \mathrm{~Hz}, 1 \mathrm{H}, \mathrm{ArH}), 7.93(\mathrm{~m}, 2 \mathrm{H}$, $\mathrm{ArH}), 7.70(\mathrm{~m}, 1 \mathrm{H}, \mathrm{ArH}) .{ }^{13} \mathrm{C}$ NMR (101 MHz, $\left.\mathrm{CDCl}_{3}: \mathrm{CH}_{3} \mathrm{CN} ; 10: 1\right) \delta 166.2,134.8,131.8$, 130.4, 125.4, 116.6, 115.4. IR 2049 (s), 1639 (s), 1565 (m), 1440 (w), 1347 (w), 1295 (m).The analysis data for the characterization of $\mathbf{3 a}$ correspond to the ones reported in the literature. ${ }^{[3]}$ Caution: Although compound 3a is relatively stable, in our lab laboratory, it detonated in two instances. Diffrential scanning calorimetry analysis confirmed its explosive character. ${ }^{[4]}$

\section{b. Synthesis of 1-azido-3,3-dimethyl-3-(1H)-1,2-benziodoxole (3b)}

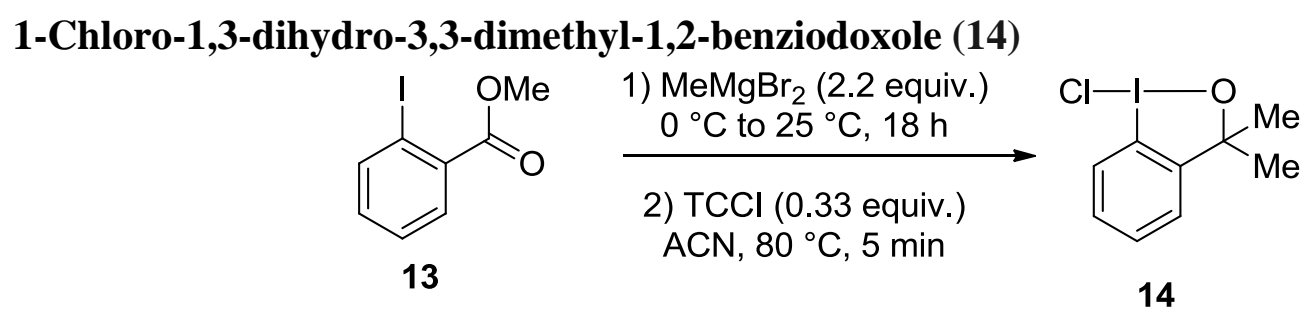

Following a reported procedure, ${ }^{[5]}$ methyl 2-iodobenzoate $13(12 \mathrm{~mL}, 76 \mathrm{mmol})$ was dissolved under $\mathrm{N}_{2}$ atmosphere in dry diethyl ether $(400 \mathrm{~mL})$ and then the solution was cooled down at 0 ${ }^{\circ} \mathrm{C}$ with an ice bath. Methylmagnesium bromide $(56.0 \mathrm{~mL}, 168 \mathrm{mmol}, 2.20$ equiv) was added dropwise and the reaction was stirred for $30 \mathrm{~min}$ at $0{ }^{\circ} \mathrm{C}$. The reaction mixture was then allowed to warm to room temperature and it was further stirred for $16 \mathrm{~h}$. The reaction was quenched with $\mathrm{NH}_{4} \mathrm{Cl}$ in an iced bath. The organic layer was separated and extracted with $\mathrm{Et}_{2} \mathrm{O}(3 \times 100 \mathrm{~mL})$, water $(2 \times 200 \mathrm{~mL})$, brine $(1 \times 100 \mathrm{~mL})$ and the combined organic layers were dried over $\mathrm{MgSO}_{4}$. The solvent was removed in vacuum. The crude mixture $(9.1 \mathrm{~g}, 33.0 \mathrm{mmol}, 1.0$ equiv.) was dissolved in anhydrous ACN $(65 \mathrm{~mL})$ and the mixture as stirred and heated at $75{ }^{\circ} \mathrm{C}$. In an additional funnel was dissolved the 1,3,5-trichloro-1,3,5-triazinane-2,4,6-trione (2.56 g, 11.0 mmol, 0.33 equiv.) in anhydrous ACN $(50 \mathrm{~mL})$. The resulting solution was added to the stirred solution of 2-(2-iodophenyl)propan-2-ol within $5 \mathrm{~min}$. The reaction was refluxed 5 min and filtered on a pad of Celite and the cake was washed with hot $\mathrm{ACN}$ ( 3 x $15 \mathrm{~mL}$ ). The resulting filtrate was concentrated un vacuum and the solid was washed with pentane $(2 \times 20 \mathrm{~mL})$ and with a minimum of cold acetone to give the compound $\mathbf{1 4}$ (7.11 g, $23.9 \mathrm{mmol}, 73 \%$ yield). ${ }^{1} \mathbf{H}$ NMR $\left(400 \mathrm{MHz}, \mathrm{CDCl}_{3}\right) \delta 8.03(\mathrm{dd}, J=8.1,1.1 \mathrm{~Hz}, 1 \mathrm{H}, \mathrm{ArH}), 7.55(\mathrm{~m}, 2 \mathrm{H}, \mathrm{ArH}), 7.17(\mathrm{dd}, J=7.3$, $1.7 \mathrm{~Hz}, 1 \mathrm{H}, \mathrm{ArH}), 1.55\left(\mathrm{~s}, 6 \mathrm{H},\left(\mathrm{CH}_{3}\right)_{2}\right) .{ }^{13} \mathbf{C ~ N M R}\left(101 \mathrm{MHz}, \mathrm{CDCl}_{3}\right) \delta 149.5,131.0,130.5$, 128.4, 126.1, 114.7, 85.2, 29.2. IR 3729 (w), 3626 (w), $2972(w), 2924(w), 2362(w), 2055(w)$, $2018(w), 1742(w), 1564(w), 1464(w), 1439(w), 1379(w), 1378(w), 1366(w), 1277(w)$, $1276(\mathrm{w}), 1256(\mathrm{w}), 1181(\mathrm{w}), 1154(\mathrm{~m}), 1112(\mathrm{w}), 1048$ (w), 1003 (w), 982 (w), 943 (m), 866 (m), $808(w), 790(w), 789(w), 762(s), 745(w), 724(w), 718(w)$. NMR data correspond to the reported values. ${ }^{[5]}$

\section{1-Acetoxy-1,3-dihydro-3,3-dimethyl-1,2-benziodoxole (15)}

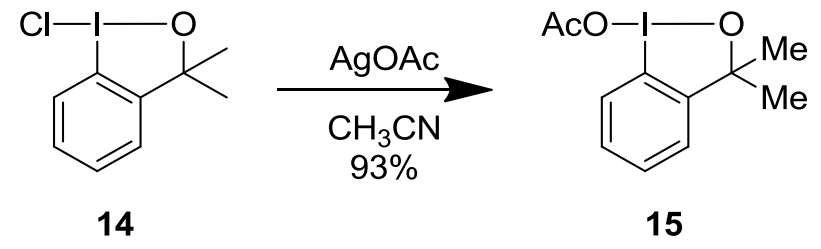


Following a reported procedure ${ }^{[5]}$ 1-Chloro-1,3-dihydro-3,3-dimethyl-1,2-benziodoxole 14 (2.60 $\mathrm{g}, 8.77 \mathrm{mmol})$ was dissolved in dry acetonitrile $(25 \mathrm{~mL})$ under $\mathrm{N}_{2}$ atmosphere. The reaction flask was covered with aluminum foils and protected from light. Silver acetate (1.46 g, $8.77 \mathrm{mmol}$, 1.00 equiv) was then added in one portion. The reaction mixture was stirred in the dark at room temperature for $16 \mathrm{~h}$. Filtration over a Celite plug and evaporation of the solvent yielded compound 15 (2.6 g, $8.8 \mathrm{mmol}, 93 \%)$ as a light brownish solid. ${ }^{1} \mathbf{H}$ NMR $\left(400 \mathrm{MHz}, \mathrm{CDCl}_{3}\right) \delta$ $7.79(\mathrm{dd}, J=8.0,1.3 \mathrm{~Hz}, 1 \mathrm{H}, \operatorname{Ar} H), 7.47$ (m, 2H, ArH), $7.18(\mathrm{dd}, J=7.2,1.7 \mathrm{~Hz}, 1 \mathrm{H}, \operatorname{Ar} H), 2.11$ $\left(\mathrm{s}, 3 \mathrm{H}, \mathrm{COCH}_{3}\right), 1.52\left(\mathrm{~s}, 6 \mathrm{H},\left(\mathrm{CH}_{3}\right)_{2}\right) .{ }^{13} \mathbf{C ~ N M R}\left(101 \mathrm{MHz}, \mathrm{CDCl}_{3}\right) \delta 177.4,149.4,130.4,130.0$, 129.9, 126.2, 115.7, 84.6, 29.2, 21.5. IR 3099 (w), 3057 (w), 2975 (w), 2930 (w), 2930 (w), 2865 (w), $1740(\mathrm{w}), 1640(\mathrm{~s}), 1588(\mathrm{w}), 1566(\mathrm{w}), 1462(\mathrm{w}), 1438(\mathrm{~m}), 1363(\mathrm{~s}), 1294(\mathrm{~s}), 1259(\mathrm{~m})$, $1158(\mathrm{~m}), 1114(\mathrm{w}), 1047(\mathrm{w}), 1033(\mathrm{w}), 1009(\mathrm{w}), 949(\mathrm{~m}), 926(\mathrm{w}), 866(\mathrm{w}), 761(\mathrm{~s}), 723(\mathrm{w})$. NMR data correspond to the reported values. ${ }^{[5]}$

\section{1-Azido-3,3-dimethyl-3-(1H)-1,2-benziodoxole (3b)}

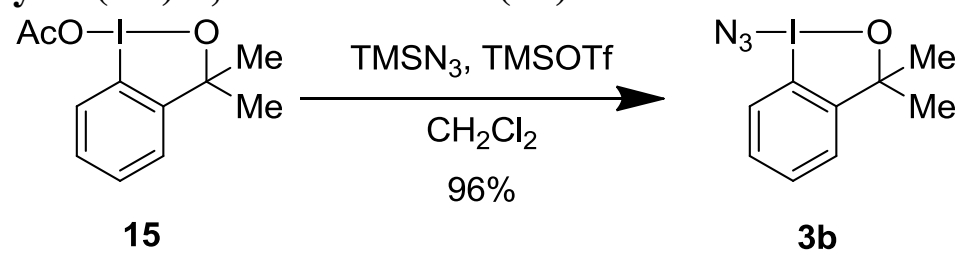

Caution: This reaction should be carried out behind a safety shield! Following a reported procedure $^{2}$ 1-Acetoxy-1,3-dihydro-3,3-dimethyl-1,2-benziodoxole 15 (2.30 g, $7.18 \mathrm{mmol}$ ) was dissolved in dry $\mathrm{CH}_{2} \mathrm{Cl}_{2}(36 \mathrm{~mL})$ under $\mathrm{N}_{2}$ atmosphere. The reaction was placed in an iced bath and trimethylsilylazide $(0.954 \mathrm{~mL}, 7.18 \mathrm{mmol}, 1.00$ equiv) was added via syringe, followed by TMSOTf $(0.065 \mathrm{~mL}, 0.36 \mathrm{mmol}, 0.050$ equiv). The reaction was stirred for $15 \mathrm{~min}$ then the ice bath was removed and the stirring was continued for $1 \mathrm{~h}$. The solvent was evaporated and the solid obtained was washed with $n$-hexane ( 2 x $30 \mathrm{~mL}$, HLPC purity) to afford $\mathbf{3 b}$ as a yellow crystalline solid (2.10 g, $7.18 \mathrm{mmol}, 96 \%) .{ }^{1} \mathbf{H} \mathbf{~ N M R}\left(400 \mathrm{MHz}, \mathrm{CDCl}_{3}\right) \delta 7.77(\mathrm{~d}, J=8.0 \mathrm{~Hz}$, $1 \mathrm{H}, \mathrm{ArH}), 7.55(\mathrm{~m}, 2 \mathrm{H}, \mathrm{ArH}), 7.23(\mathrm{~d}, J=7.2 \mathrm{~Hz}, 1 \mathrm{H}, \mathrm{ArH}), 1.53\left(\mathrm{~s}, 6 \mathrm{H},\left(\mathrm{CH}_{3}\right)_{2}\right) .{ }^{13} \mathbf{C}$ NMR $(101$ $\left.\mathrm{MHz}, \mathrm{CDCl}_{3}\right) \delta 149.2,130.9,130.4,127.8,126.8,114.0,83.2,29.6$. IR $3254(\mathrm{w}), 3085(\mathrm{w}), 3051$ (w), $2976(\mathrm{w}), 2928(\mathrm{w}), 2860(\mathrm{w}), 2486(\mathrm{w}), 2026(\mathrm{~s}), 1918(\mathrm{w}), 1764(\mathrm{w}), 1697(\mathrm{w}), 1651(\mathrm{w})$, $1589(\mathrm{w}), 1562$ (w), 1462 (m), $1428(\mathrm{~m}), 1380(\mathrm{w}), 1364$ (w), $1312(\mathrm{w}), 1273$ (w), 1248 (s), 1182 (w), $1151(\mathrm{~m}), 1111(\mathrm{~m}), 1031(\mathrm{w}), 1004$ (w), 943 (m), 910 (m), 880 (w), 863 (m). NMR data correspond to the reported values. ${ }^{[5]}$ 


\section{Synthesis of starting materials}

\section{a. General procedure for synthesis of ketone precursors using Friedel- Craft reaction}
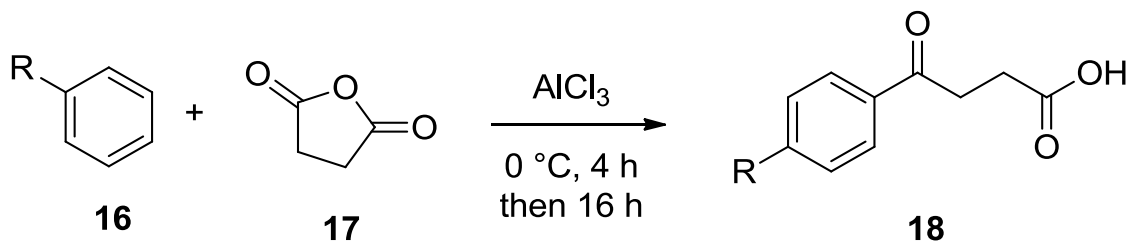

A $100-\mathrm{mL}$, three-necked, round-bottomed flask is charged with powdered dihydrofuran-2,5-dione 17 (1.0 equiv.) and arene 16 (1.0 equiv.) under dry nitrogen. The resulting white mixture was cooled to $0{ }^{\circ} \mathrm{C}$ before anhydrous aluminum trichloride (1.2 equiv.) was added in one portion. The reaction mixture was stirred over a period of $4 \mathrm{~h}$ before allowing it to warm to room temperature for $16 \mathrm{~h}$. The reaction was poured in ice and $10 \mathrm{~mL}$ of concentrated hydrochloric acid was added under stirring at $0{ }^{\circ} \mathrm{C}$. The organic layer was separated and the aqueous layer was extracted with DCM twice. The combined organic layers were washed with water, dried over $\mathrm{MgSO}_{4}$ and concentrated. Product was engaged in the next step without further purification.

\section{4-(4-Methoxyphenyl)-4-oxobutanoic acid (18a)}<smiles>COc1ccc(C(=O)CCC(=O)O)cc1</smiles>

According to the general procedure, starting from dihydrofuran-2,5-dione $17(2.75 \mathrm{~g}, 27.5 \mathrm{mmol}$, 1.0 equiv.), aluminum trichloride ( $4.41 \mathrm{~g}, 33.0 \mathrm{mmol}, 1.2$ equiv.) and anisole $16 \mathbf{a}(3.00 \mathrm{~mL}, 27.5$ $\mathrm{mmol})$, the product was obtained as a white solid $\left(4.67 \mathrm{~g}, 22.4 \mathrm{mmol}, 82 \%\right.$ yield). ${ }^{1} \mathbf{H}$ NMR (400 $\left.\mathrm{MHz}, \mathrm{CDCl}_{3}\right) \delta 7.96(\mathrm{~d}, J=8.8 \mathrm{~Hz}, 2 \mathrm{H}, \mathrm{Ar} H), 6.94(\mathrm{~d}, J=8.8 \mathrm{~Hz}, 2 \mathrm{H}, \operatorname{Ar} H), 3.87(\mathrm{~s}, 3 \mathrm{H}, M e)$, $3.27\left(\mathrm{t}, J=6.6 \mathrm{~Hz}, 2 \mathrm{H}, \mathrm{CH}_{2} \mathrm{CH}_{2} \mathrm{CO}_{2} \mathrm{H}\right), 2.80\left(\mathrm{t}, J=6.6 \mathrm{~Hz}, 2 \mathrm{H}, \mathrm{CH}_{2} \mathrm{CH}_{2} \mathrm{CO}_{2} \mathrm{H}\right)$. NMR data correspond to the reported values. ${ }^{[6]}$

\section{4-(4-Fluorophenyl)-4-oxobutanoic acid (18b)}<smiles>O=C(O)CCC(=O)c1ccc(F)cc1</smiles>

According to the general procedure, starting from dihydrofuran-2,5-dione 17 (2.75 g, $27.5 \mathrm{mmol}$, 1.0 equiv.), aluminum trichloride ( $4.41 \mathrm{~g}, 33.0 \mathrm{mmol}, 1.2$ equiv.) and fluorobenzene $\mathbf{1 6 b}$ (3.89 $\mathrm{mL}, 41.2 \mathrm{mmol} 1.0$ equiv.), the product was obtained as a white solid $(4.12 \mathrm{~g}, 20.9 \mathrm{mmol}, 76 \%$ yield). ${ }^{1} \mathbf{H}$ NMR $\left(400 \mathrm{MHz}, \mathrm{CDCl}_{3}\right) \delta 8.01(\mathrm{dd}, J=8.6,5.4 \mathrm{~Hz}, 2 \mathrm{H}, \mathrm{Ar} H), 7.14(\mathrm{t}, J=8.5 \mathrm{~Hz}$, $2 \mathrm{H}, \mathrm{ArH}$ ), 3.28 (t, $\left.J=6.5 \mathrm{~Hz}, 2 \mathrm{H}, \mathrm{CH}_{2} \mathrm{CH}_{2} \mathrm{CO}_{2} \mathrm{H}\right), 2.81$ (t, $J=6.5 \mathrm{~Hz}, 2 \mathrm{H}, \mathrm{CH}_{2} \mathrm{CH}_{2} \mathrm{CO}_{2} \mathrm{H}$ ). NMR data correspond to the reported values. ${ }^{[6]}$ 


\section{4-(4-Bromophenyl)-4-oxobutanoic acid (18c)}<smiles>O=C(O)CCC(=O)c1ccc(Br)cc1</smiles>

According to the general procedure, starting from dihydrofuran-2,5-dione 17 ( $2.85 \mathrm{~g}, 28.5 \mathrm{mmol}$, 1.0 equiv.), aluminum trichloride (4.56 g, $34.2 \mathrm{mmol}, 1.2$ equiv.) and bromobenzene 16c (3.05 $\mathrm{mL}, 28.5 \mathrm{mmol}, 1.0$ equiv.), the product was obtained as a white solid (4.80 g, $18.7 \mathrm{mmol}, 65 \%$ yield). ${ }^{1} \mathbf{H}$ NMR $\left(400 \mathrm{MHz}, \mathrm{CDCl}_{3}\right) \delta 7.84(\mathrm{~d}, J=8.3 \mathrm{~Hz}, 2 \mathrm{H}, \operatorname{Ar} H), 7.61(\mathrm{~d}, J=8.6 \mathrm{~Hz}, 2 \mathrm{H}$, $\mathrm{ArH}), 3.27\left(\mathrm{t}, J=6.5 \mathrm{~Hz}, 2 \mathrm{H}, \mathrm{CH}_{2} \mathrm{CH}_{2} \mathrm{CO}_{2} \mathrm{H}\right), 2.81\left(\mathrm{t}, J=6.5 \mathrm{~Hz}, 2 \mathrm{H}, \mathrm{CH}_{2} \mathrm{CH}_{2} \mathrm{CO}_{2} \mathrm{H}\right)$. NMR data correspond to the reported values. ${ }^{[6]}$

\section{4-(4-Chlorophenyl)-4-oxobutanoic acid (18d)}<smiles>O=C(O)CCC(=O)c1ccc(Cl)cc1</smiles>

According to the general procedure, starting from dihydrofuran-2,5-dione 17 (2.93 g, $29.3 \mathrm{mmol}$, 1.0 equiv.), aluminum trichloride (4.69 g, $35.2 \mathrm{mmol}, 1.2$ equiv.) and chlorobenzene $16 \mathbf{d}$ (3.00 $\mathrm{mL}, 29.3 \mathrm{mmol}, 1.0$ equiv.), the product was obtained as a white solid (4.75 g, $22.3 \mathrm{mmol}, 76 \%$ yield). ${ }^{1} \mathbf{H}$ NMR $\left(400 \mathrm{MHz}, \mathrm{CDCl}_{3}\right) \delta 7.92(\mathrm{~d}, J=8.3 \mathrm{~Hz}, 2 \mathrm{H}, \mathrm{ArH}), 7.44(\mathrm{~d}, J=8.3 \mathrm{~Hz}, 2 \mathrm{H}$, $\mathrm{ArH}), 3.28\left(\mathrm{t}, J=6.5 \mathrm{~Hz}, 2 \mathrm{H}, \mathrm{CH}_{2} \mathrm{CH}_{2} \mathrm{CO}_{2} \mathrm{H}\right), 2.81\left(\mathrm{t}, J=6.5 \mathrm{~Hz}, 2 \mathrm{H}, \mathrm{CH}_{2} \mathrm{CH}_{2} \mathrm{CO}_{2} \mathrm{H}\right)$. NMR data correspond to the reported values. ${ }^{[6]}$

\section{4-(2,5-Dimethylphenyl)-4-oxobutanoic acid (18e)}<smiles>Cc1ccc(C)c(C(=O)CCC(=O)O)c1</smiles>

According to the general procedure, starting from dihydrofuran-2,5-dione 17 (2.45 g, $24.5 \mathrm{mmol}$, 1.0 equiv.), aluminum trichloride (3.92 g, $29.4 \mathrm{mmol}, 1.2$ equiv.) and p-xylene 16e $(3.00 \mathrm{~mL}$, $24.5 \mathrm{mmol}, 1.0$ equiv.), the product was obtained as a beige solid (2.7 g, $13 \mathrm{mmol}, 53 \%$ yield). ${ }^{1} \mathbf{H}$ NMR $\left(400 \mathrm{MHz}, \mathrm{CDCl}_{3}\right) \delta 7.50(\mathrm{~d}, J=1.8 \mathrm{~Hz}, 1 \mathrm{H}, \mathrm{ArH}), 7.19(\mathrm{dd}, J=7.9,1.7 \mathrm{~Hz}, 1 \mathrm{H}$, $\mathrm{ArH}), 7.13(\mathrm{~d}, J=7.8 \mathrm{~Hz}, 1 \mathrm{H}, \mathrm{ArH}), 3.22\left(\mathrm{t}, J=6.5 \mathrm{~Hz}, 2 \mathrm{H}, \mathrm{CH}_{2} \mathrm{CH}_{2} \mathrm{CO}_{2} \mathrm{H}\right), 2.79$ (t, $J=6.5 \mathrm{~Hz}$, $\left.2 \mathrm{H}, \mathrm{CH}_{2} \mathrm{CH}_{2} \mathrm{CO}_{2} \mathrm{H}\right), 2.45(\mathrm{~s}, 3 \mathrm{H}, M e), 2.36(\mathrm{~s}, 3 \mathrm{H}, M e)$. NMR data correspond to the reported values. ${ }^{[6]}$

\section{3,3-Dimethyl-5-oxo-5-phenylpentanoic acid (20)}<smiles>CC1(C)CC(=O)OC(=O)C1</smiles>

$16 f$

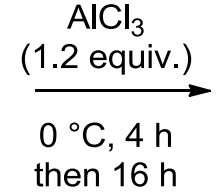

19<smiles>CC(C)(CC(=O)O)CC(=O)c1ccccc1</smiles>

20 
A 100-mL, three-necked, round-bottomed flask was charged with powdered 3,3-Dimethylglutaric anhydride 19 ( $1.50 \mathrm{~g}, 10.5 \mathrm{mmol}, 1.0$ equiv.) and benzene $\mathbf{1 6 f}$ ( $3.00 \mathrm{~mL}, 33.4 \mathrm{mmol}, 3.0$ equiv.) under dry argon. The resulting white mixture was cooled to $0{ }^{\circ} \mathrm{C}$ before anhydrous aluminum trichloride (1.688 g, $12.66 \mathrm{mmol}, 1.2$ equiv.) is added in one portion. The reaction mixture is stirred over a period of $4 \mathrm{~h}$ before allowing it to warm to room temperature for $16 \mathrm{~h}$. The reaction was poured in ice and $10 \mathrm{~mL}$ of concentrated hydrochloric acid was added under stirring at $0{ }^{\circ} \mathrm{C}$. The organic layer was separated and the aqueous layer was extracted with DCM twice $(2 \times 30$ $\mathrm{mL}$ ). The combined organic layers were washed with water, dried over $\mathrm{MgSO}_{4}$ and concentrated to give the expected compound 20 (1.70 g, $7.72 \mathrm{mmol}, 73 \%$ yield). ${ }^{1} \mathbf{H}$ NMR (400 MHz, $\left.\mathrm{CDCl}_{3}\right) \delta 7.96(\mathrm{~d}, J=8.3 \mathrm{~Hz}, 2 \mathrm{H}, \mathrm{ArH}), 7.60-7.54(\mathrm{~m}, 1 \mathrm{H}, \mathrm{ArH}), 7.46(\mathrm{t}, J=7.6 \mathrm{~Hz}, 2 \mathrm{H}, \operatorname{Ar} H)$, $3.12\left(\mathrm{~s}, 2 \mathrm{H}, \mathrm{CH}_{2} \mathrm{CO}_{2} \mathrm{H}\right), 2.59\left(\mathrm{~s}, 2 \mathrm{H}, \mathrm{C}=\mathrm{CCH}_{2} \mathrm{CMe}_{2}\right), 1.18$ (s, 6H, 2Me). NMR data correspond to the reported values. ${ }^{[7]}$

\section{4-Oxo-6-phenylhex-5-ynoic acid (22)}

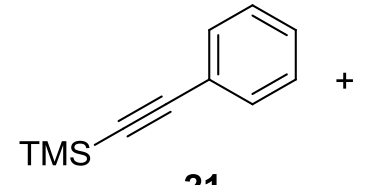

21<smiles>O=C1CCC(=O)O1</smiles>

17

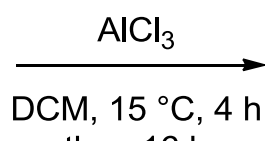

then $16 \mathrm{~h}$

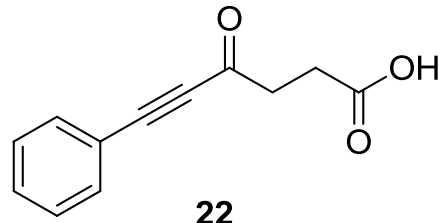

22

To a solution of succinic anhydride 17 (1.2 g, $12 \mathrm{mmol}, 1.2$ equiv.) in DCM (125 $\mathrm{mL})$ in a $250 \mathrm{~mL}$ round-bottom flask fitted with a thermometer, and solvent addition funnel was added aluminum trichloride $(2.3 \mathrm{~g}, 17 \mathrm{mmol})$. The reaction mass was cooled under stirring to $15^{\circ} \mathrm{C}$ and a solution of trimethyl(phenylethynyl)silane $21(2.0 \mathrm{~mL}, 10 \mathrm{mmol})$ in $10 \mathrm{~mL}$ of DCM was added dropwise and the reaction mixture was stirred for $16 \mathrm{~h}$ at $\mathrm{rt}$. The reaction was poured in ice and $10 \mathrm{~mL}$ of concentrated hydrochloric acid was added under stirring at $0{ }^{\circ} \mathrm{C}$. The organic layer was separated and the aqueous layer was extracted with DCM twice $(2 \times 50 \mathrm{~mL})$. The combined organic layers were washed with water, dried over $\mathrm{MgSO}_{4}$ and concentrated to give the expected compound 22 (1.00 g, $4.95 \mathrm{mmol}, 49 \%$ yield). ${ }^{1} \mathbf{H}$ NMR (400 $\left.\mathrm{MHz}, \mathrm{CDCl}_{3}\right) \delta 7.58(\mathrm{~d}, J=7.5$ $\mathrm{Hz}, 2 \mathrm{H}, \operatorname{ArH}), 7.47(\mathrm{t}, J=7.4 \mathrm{~Hz}, 1 \mathrm{H}, \operatorname{ArH}), 7.39(\mathrm{t}, J=7.5 \mathrm{~Hz}, 2 \mathrm{H}$. ArH), 3.02 (t, $J=6.6 \mathrm{~Hz}$, $\left.2 \mathrm{H}, \mathrm{CH}_{2}\right), 2.77\left(\mathrm{t}, J=6.6 \mathrm{~Hz}, 2 \mathrm{H}, \mathrm{CH}_{2}\right)$. NMR data correspond to the reported values. ${ }^{[8]}$

\section{2-(4-Fluorobenzoyl)benzoic acid (24)}

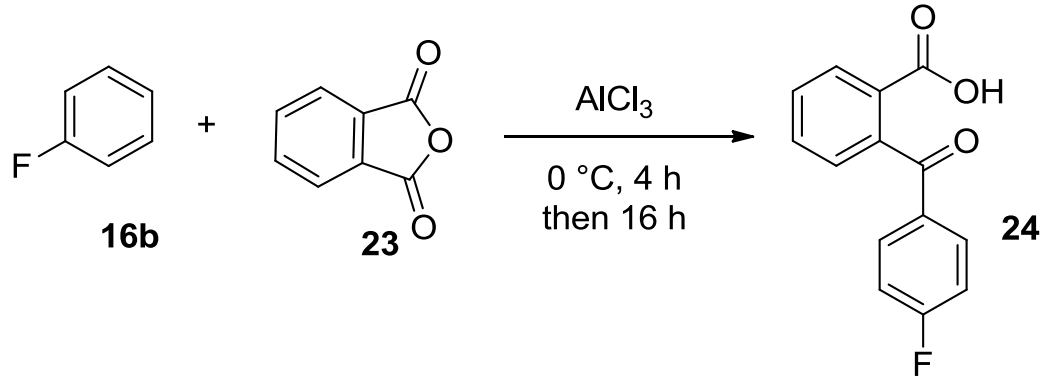

A $100-\mathrm{mL}$, three-necked, round-bottomed flask is charged with powdered phthalic anhydride $\mathbf{2 3}$ (3.26 g, $22.0 \mathrm{mmol}, 1.0$ equiv.) and fluorobenzene $\mathbf{1 6 b}(6.00 \mathrm{~mL}, 66.0 \mathrm{mmol}, 3.0$ equiv.) under dry nitrogen. The resulting white mixture was cooled to $0{ }^{\circ} \mathrm{C}$ before anhydrous aluminum trichloride ( $4.40 \mathrm{~g}, 33.0 \mathrm{mmol}, 1.5$ equiv.) was added in one portion. The reaction mixture was stirred over a period of $1 \mathrm{hr}$ before the reaction mixture is allowed to warm to room temperature for $16 \mathrm{~h}$. The reaction was poured in ice and $10 \mathrm{~mL}$ of concentrated hydrochloric acid was added 
under stirring at $0{ }^{\circ} \mathrm{C}$. The organic layer was separated and the aqueous layer was extracted with DCM twice $(2 \times 30 \mathrm{~mL})$. The combined organic layers were washed with water, dried over $\mathrm{MgSO}_{4}$ and concentrated to give the expected compound 254 (2.35 g, $9.42 \mathrm{mmol}, 42 \%$ yield). ${ }^{\mathbf{1}} \mathbf{H}$ NMR $\left(400 \mathrm{MHz}, \mathrm{CDCl}_{3}\right) \delta 8.09(\mathrm{~d}, J=7.8 \mathrm{~Hz}, 1 \mathrm{H}, \mathrm{Ar} H), 7.74(\mathrm{dd}, J=8.4,5.5 \mathrm{~Hz}, 2 \mathrm{H}, \operatorname{Ar} H)$, $7.68(\mathrm{t}, J=7.5 \mathrm{~Hz}, 1 \mathrm{H}, \operatorname{Ar} H), 7.58(\mathrm{t}, J=7.7 \mathrm{~Hz}, 1 \mathrm{H}, \operatorname{Ar} H), 7.36(\mathrm{~d}, J=7.5 \mathrm{~Hz}, 1 \mathrm{H}, \operatorname{Ar} H), 7.08$ $(\mathrm{t}, J=8.5 \mathrm{~Hz}, 2 \mathrm{H}, \mathrm{ArH})$. NMR data correspond to the reported values. ${ }^{[9]}$

\section{b. General procedure for synthesis of enoic acid using Wittig reaction}

Under nitrogen, to a solution of $t \mathrm{BuOK}$ (2.6 equiv.) in dry THF $(0.5 \mathrm{M})$ was added bromo(methyl)triphenylphosphorane (1.3 equiv.) in portions at $0{ }^{\circ} \mathrm{C}$. The mixture was stirred at 0 ${ }^{\circ} \mathrm{C}$ for $30 \mathrm{~min}$ and a solution of ketone (1.0 equiv.) in dry THF $(1 \mathrm{M})$ was added dropwise and the reaction was stirred at $0{ }^{\circ} \mathrm{C}$ for $1 \mathrm{~h}$ and at $\mathrm{rt}$ overnight. The solvent was removed in vacuo and the residue diluted with DCM and aqueous $\mathrm{NaOH}(1 \mathrm{M})$. The aqueous layer was separated, washed with dichloromethane, and acidified to $\mathrm{pH} 1$ with concentrated $\mathrm{HCl}$. DCM was added and the organic compound was extracted twice with DCM. The organic layer was washed with water, dried over $\mathrm{MgSO}_{4}$ and concentrated. The crude product was purified by $\mathrm{SiO}_{2}$ column chromatography (DCM/MeOH: 100/0 to 95/5 to 9/1) to give pure enoic acid.

\section{4-Phenylpent-4-enoic acid (1a)}<smiles>C=C(CCC(=O)O)c1ccccc1</smiles>

According to the general procedure, starting from 4-oxo-4-phenylbutanoic acid (3.00 g, 16.8 mmol, 1.0 equiv.), tBuOK (4.91 g, $43.8 \mathrm{mmol}, 2.6 \mathrm{equiv}$.$) and$ bromo(methyl)triphenylphosphorane (7.82 g, $21.9 \mathrm{mmol}, 1.3$ equiv.), the product was obtained as a white solid (2.75 g, $15.6 \mathrm{mmol}, 93 \%$ yield). ${ }^{1} \mathbf{H}$ NMR (400 $\left.\mathrm{MHz}, \mathrm{CDCl}_{3}\right) \delta 11.60(\mathrm{bs}, 1 \mathrm{H})$, $7.46-7.27(\mathrm{~m}, 5 \mathrm{H}, \mathrm{ArH}), 5.35\left(\mathrm{~s}, 2 \mathrm{H}, \mathrm{C}=\mathrm{CH}_{2}\right), 2.87\left(\mathrm{t}, J=7.8 \mathrm{~Hz}, 2 \mathrm{H}, \mathrm{CH}_{2} \mathrm{CH}_{2} \mathrm{CO}_{2} \mathrm{H}\right), 2.56$ $\left(\mathrm{dd}, J=8.9,6.7 \mathrm{~Hz}, 2 \mathrm{H}, \mathrm{CH}_{2} \mathrm{CH}_{2} \mathrm{CO}_{2} \mathrm{H}\right) .{ }^{13} \mathbf{C} \mathbf{N M R}\left(101 \mathrm{MHz}, \mathrm{CDCl}_{3}\right) \delta 179.9,146.6,140.5$, 128.6, 127.8, 126.2, 113.1, 33.1, 30.2. NMR data correspond to the reported values. ${ }^{[10]}$

\section{4-(p-Tolyl)pent-4-enoic acid (1b)}<smiles>C=C(CCC(=O)O)c1ccc(C)cc1</smiles>

According to the general procedure, starting from 4-oxo-4-(p-tolyl)butanoic acid (2.00 g, 10.2 mmol, $\quad 1.0$ equiv.), tBuOK $(3.00 \mathrm{~g}, \quad 26.7 \mathrm{mmol}, 2.6$ equiv.) and bromo(methyl)triphenylphosphorane ( $4.78 \mathrm{~g}, 13.4 \mathrm{mmol}, 1.3$ equiv.), the product was obtained as a white solid (1.70 g, $8.94 \mathrm{mmol}, 87 \%$ yield). ${ }^{1} \mathbf{H}$ NMR $\left(400 \mathrm{MHz}, \mathrm{CDCl}_{3}\right) \delta 7.33(\mathrm{~d}, J=8.2 \mathrm{~Hz}$, $2 \mathrm{H}, \operatorname{Ar} H), 7.17(\mathrm{~d}, J=8.0 \mathrm{~Hz}, 2 \mathrm{H}, \mathrm{ArH}), 5.33\left(\mathrm{~d}, J=1.0 \mathrm{~Hz}, 1 \mathrm{H}, \mathrm{C}=\mathrm{CH}_{2}\right), 5.09$ (q, $J=1.2 \mathrm{~Hz}$, $\left.1 \mathrm{H}, \mathrm{C}=\mathrm{CH}_{2}\right), 2.90-2.83\left(\mathrm{~m}, 2 \mathrm{H}, \mathrm{CH}_{2} \mathrm{CH}_{2} \mathrm{CO}_{2} \mathrm{H}\right), 2.61-2.52\left(\mathrm{~m}, 2 \mathrm{H}, \mathrm{CH}_{2} \mathrm{CH}_{2} \mathrm{CO}_{2} \mathrm{H}\right), 2.38(\mathrm{~s}$, $3 \mathrm{H}, \mathrm{Me}) .{ }^{13} \mathrm{C}$ NMR $\left(101 \mathrm{MHz}, \mathrm{CDCl}_{3}\right) \delta 179.8,146.4,137.6,137.5,129.2,126.0,112.3,33.2$, 30.2, 21.2. NMR data correspond to the reported values. ${ }^{[11]}$ 
4-(4-Methoxyphenyl)pent-4-enoic acid (1c)<smiles>C=C(CCC(=O)O)c1ccc(OC)cc1</smiles>

According to the general procedure, starting from 4-(4-methoxyphenyl)-4-oxobutanoic acid 18a $(1.10 \mathrm{~g}, \quad 5.28 \mathrm{mmol}, 1.0$ equiv.), tBuOK (1.54 g, $13.7 \mathrm{mmol}, 2.6$ equiv.) and bromo(methyl)triphenylphosphorane ( $2.45 \mathrm{~g}, 6.87 \mathrm{mmol}, 1.3$ equiv.), the product was obtained as a white solid $\left(0.71 \mathrm{~g}, 3.44 \mathrm{mmol}, 65 \%\right.$ yield). ${ }^{1} \mathbf{H}$ NMR $\left(400 \mathrm{MHz}, \mathrm{CDCl}_{3}\right) \delta 7.39-7.30(\mathrm{~m}, 2 \mathrm{H}$, $\mathrm{ArH}), 6.91-6.83(\mathrm{~m}, 2 \mathrm{H}, \mathrm{ArH}), 5.25\left(\mathrm{~d}, J=1.0 \mathrm{~Hz}, 1 \mathrm{H}, \mathrm{C}=\mathrm{CH}_{2}\right), 5.03(\mathrm{~d}, J=1.2 \mathrm{~Hz}, 1 \mathrm{H}$, $\left.\mathrm{C}=\mathrm{CH}_{2}\right), 3.82(\mathrm{~s}, 3 \mathrm{H}, \mathrm{Me}), 2.88-2.75\left(\mathrm{~m}, 2 \mathrm{H}, \mathrm{CH}_{2} \mathrm{CH}_{2} \mathrm{CO}_{2} \mathrm{H}\right), 2.64-2.43(\mathrm{~m}, 2 \mathrm{H}$, $\left.\mathrm{CH}_{2} \mathrm{CH}_{2} \mathrm{CO}_{2} \mathrm{H}\right) .{ }^{13} \mathrm{C}$ NMR $\left(101 \mathrm{MHz}, \mathrm{CDCl}_{3}\right) \delta 178.9,159.4,146.0,133.0,127.3,113.9,111.6$, $55.4,33.1,30.3$. NMR data correspond to the reported values. ${ }^{[11]}$

\section{4-(4-Bromophenyl)pent-4-enoic acid (1d)}<smiles>C=C(CCC(=O)O)c1ccc(Br)cc1</smiles>

According to the general procedure, starting from 4-(4-bromophenyl)-4-oxobutanoic acid 18c (2.00 g, 7.78 mmol, 1.0 equiv.), tBuOK (2.27 g, $20.2 \mathrm{mmol}, 2.6$ equiv.) and bromo(methyl)triphenylphosphorane ( $3.61 \mathrm{~g}, 10.1 \mathrm{mmol}, 1.3$ equiv.), the product was obtained as a white solid $\left(1.50 \mathrm{~g}, 5.88 \mathrm{mmol}, 76 \%\right.$ yield. ${ }^{1} \mathbf{H}$ NMR $\left(400 \mathrm{MHz},\left(\mathrm{CD}_{3}\right)_{2} \mathrm{SO}\right) \delta 12.18(\mathrm{~s}, 1 \mathrm{H}$, $\left.\mathrm{CO}_{2} \mathrm{H}\right), 7.59-7.50(\mathrm{~m}, 2 \mathrm{H}, \mathrm{ArH}), 7.45-7.38(\mathrm{~m}, 2 \mathrm{H}, \mathrm{ArH}), 5.39\left(\mathrm{~s}, 1 \mathrm{H}, \mathrm{C}=\mathrm{CH}_{2}\right), 5.13(\mathrm{~d}, J=$ $\left.1.4 \mathrm{~Hz}, 1 \mathrm{H}, \mathrm{C}=\mathrm{CH}_{2}\right), 2.70\left(\mathrm{t}, J=7.6 \mathrm{~Hz}, 2 \mathrm{H}, \mathrm{CH}_{2} \mathrm{CH}_{2} \mathrm{CO}_{2} \mathrm{H}\right), 2.36(\mathrm{dd}, J=8.4,6.7 \mathrm{~Hz}, 2 \mathrm{H}$, $\left.\mathrm{CH}_{2} \mathrm{CH}_{2} \mathrm{CO}_{2} \mathrm{H}\right) .{ }^{13} \mathrm{C}$ NMR $\left(101 \mathrm{MHz},\left(\mathrm{CD}_{3}\right)_{2} \mathrm{SO}\right) \delta 173.8,145.4,139.3,131.4,128.0,120.8$, $113.3,32.5,29.4$. NMR data correspond to the reported values. ${ }^{[12]}$

\section{4-(4-Fluorophenyl)pent-4-enoic acid (1e)}<smiles>C=C(CCC(=O)O)c1ccc(F)cc1</smiles>

According to the general procedure, starting from 4-(4-fluorophenyl)-4-oxobutanoic acid $\mathbf{1 8 b}$ (2.00 g, $10.2 \mathrm{mmol}), 1.0$ equiv.), tBuOK (2.97 g, $26.5 \mathrm{mmol}, 2.6$ equiv.) and bromo(methyl)triphenylphosphorane (4.73 g, $13.2 \mathrm{mmol}, 1.3$ equiv.), the product was obtained as a white solid $(1.70 \mathrm{~g}, 8.75 \mathrm{mmol}, 86 \%$ yield $) .{ }^{1} \mathbf{H} \mathbf{~ N M R}\left(400 \mathrm{MHz}, \mathrm{CDCl}_{3}\right) \delta 7.41-7.32(\mathrm{~m}, 2 \mathrm{H}$, $\mathrm{ArH}), 7.02(\mathrm{t}, J=8.7 \mathrm{~Hz}, 2 \mathrm{H}, \mathrm{ArH}), 5.27\left(\mathrm{~s}, 1 \mathrm{H}, \mathrm{C}=\mathrm{CH}_{2}\right), 5.09\left(\mathrm{~s}, 1 \mathrm{H}, \mathrm{C}=\mathrm{CH}_{2}\right), 2.81(\mathrm{t}, J=7.7$ $\left.\mathrm{Hz}, 2 \mathrm{H}, \mathrm{CH}_{2} \mathrm{CH}_{2} \mathrm{CO}_{2} \mathrm{H}\right), 2.51\left(\mathrm{t}, J=7.9 \mathrm{~Hz}, 2 \mathrm{H}, \mathrm{CH}_{2} \mathrm{CH}_{2} \mathrm{CO}_{2} \mathrm{H}\right) .{ }^{13} \mathbf{C ~ N M R}\left(101 \mathrm{MHz}, \mathrm{CDCl}_{3}\right) \delta$ $179.7,162.5(\mathrm{~d}, J=246.6 \mathrm{~Hz}), 145.6,136.6(\mathrm{~d}, J=3.3 \mathrm{~Hz}), 127.8(\mathrm{~d}, J=8.0 \mathrm{~Hz}), 115.4(\mathrm{~d}, J=$ $21.3 \mathrm{~Hz}), 113.1,33.0,30.3$. NMR data correspond to the reported values. ${ }^{[11]}$

\section{4-(4-Chlorophenyl)pent-4-enoic acid (1f)}<smiles>C=C(CCC(=O)O)c1ccc(Cl)cc1</smiles> 
According to the general procedure, starting from 4-(4-chlorophenyl)-4-oxobutanoic acid 18d $(1.65 \mathrm{~g}, \quad 7.78 \mathrm{mmol}, \quad 1.0$ equiv.), tBuOK (2.27 g, $20.2 \mathrm{mmol}, 2.6$ equiv.) and bromo(methyl)triphenylphosphorane (3.61 g, $10.1 \mathrm{mmol}, 1.3$ equiv.), the product was obtained as a white solid (1.0 g, $4.8 \mathrm{mmol}, 61 \%$ yield). ${ }^{1} \mathbf{H}$ NMR $\left(400 \mathrm{MHz}, \mathrm{CDCl}_{3}\right) \delta 7.35-7.28(\mathrm{~m}, 4 \mathrm{H}$, $\operatorname{ArH}), 5.31\left(\mathrm{~s}, 1 \mathrm{H}, \mathrm{C}=\mathrm{CH}_{2}\right), 5.12\left(\mathrm{~d}, J=1.3 \mathrm{~Hz}, 1 \mathrm{H}, \mathrm{C}=\mathrm{CH}_{2}\right), 2.81(\mathrm{t}, J=7.4 \mathrm{~Hz}, 2 \mathrm{H}$, $\left.\mathrm{CH}_{2} \mathrm{CH}_{2} \mathrm{CO}_{2} \mathrm{H}\right), 2.52\left(\mathrm{~m}, 2 \mathrm{H}, \mathrm{CH}_{2} \mathrm{CH}_{2} \mathrm{CO}_{2} \mathrm{H}\right) .{ }^{13} \mathbf{C} \mathbf{N M R}\left(101 \mathrm{MHz}, \mathrm{CDCl}_{3}\right) \delta$ 178.8, 145.6, $139.0,133.7,128.7,127.5,113.7,32.9,30.1$. NMR data correspond to the reported values. ${ }^{[1]]}$

\section{2-(Prop-1-en-2-yl)benzoic acid (1g)}<smiles>C=C(C)c1ccccc1C(=O)O</smiles>

According to the general procedure, starting from 2-acetylbenzoic acid $(1.70 \mathrm{~g}, 10.3 \mathrm{mmol}, 1.0$ equiv.), tBuOK (3.02 g, 26.9 mmol, 2.6 equiv.) and bromo(methyl)triphenylphosphorane (4.81 g, $13.5 \mathrm{mmol}, 1.3$ equiv.), the product was obtained as a white solid (1.5 g, $9.3 \mathrm{mmol}, 89 \%$ yield). ${ }^{1} \mathbf{H}$ NMR $\left(400 \mathrm{MHz}, \mathrm{CDCl}_{3}\right) \delta 7.96(\mathrm{~d}, J=7.6 \mathrm{~Hz}, 1 \mathrm{H}, \mathrm{Ar} H), 7.51(\mathrm{t}, J=7.5 \mathrm{~Hz}, 1 \mathrm{H}, \operatorname{Ar} H), 7.36$ $(\mathrm{t}, J=7.6 \mathrm{~Hz}, 1 \mathrm{H}, \operatorname{Ar} H), 7.27(\mathrm{~d}, J=7.5 \mathrm{~Hz}, 1 \mathrm{H}, \operatorname{Ar} H), 5.13\left(\mathrm{~s}, 1 \mathrm{H}, \mathrm{C}=\mathrm{CH}_{2}\right), 4.90(\mathrm{~s}, 1 \mathrm{H}$, $\left.\mathrm{C}=\mathrm{CH}_{2}\right), 2.13(\mathrm{~s}, 3 \mathrm{H}, \mathrm{Me}) .{ }^{13} \mathrm{C}$ NMR $\left(101 \mathrm{MHz}, \mathrm{CDCl}_{3}\right) \delta 173.7,146.8,146.5,132.8,130.9$, $129.9,128.2,127.2,114.1,24.5$. NMR data correspond to the reported values. ${ }^{[10]}$

\section{2-(1-Phenylvinyl)benzoic acid (1h)}<smiles>C=C(c1ccccc1)c1ccccc1C(=O)O</smiles>

According to the general procedure, starting from 2-benzoylbenzoic acid $(1.50 \mathrm{~g}, 6.63 \mathrm{mmol}, 1.0$ equiv.), tBuOK (1.93 g, $17.2 \mathrm{mmol}, 2.6$ equiv.) and bromo(methyl)triphenylphosphorane (3.08 g, $8.62 \mathrm{mmol}, 1.3$ equiv.), the product was obtained as a white solid $(0.60 \mathrm{~g}, 2.7 \mathrm{mmol}, 40 \%$ yield). ${ }^{1} \mathbf{H}$ NMR $\left(400 \mathrm{MHz}, \mathrm{CDCl}_{3}\right) \delta 7.93(\mathrm{dd}, J=7.8,1.4 \mathrm{~Hz}, 1 \mathrm{H}, \mathrm{Ar} H), 7.57(\mathrm{td}, J=7.5,1.5 \mathrm{~Hz}, 1 \mathrm{H}$, $\operatorname{Ar} H$ ), $7.43(\mathrm{td}, J=7.6,1.4 \mathrm{~Hz}, 1 \mathrm{H}, \operatorname{Ar} H), 7.38(\mathrm{dd}, J=7.6,1.3 \mathrm{~Hz}, 1 \mathrm{H}, \operatorname{Ar} H), 7.28-7.18(\mathrm{~m}$, $5 \mathrm{H}, \operatorname{Ar} H), 5.67\left(\mathrm{~d}, J=1.0 \mathrm{~Hz}, 1 \mathrm{H}, \mathrm{C}=\mathrm{CH}_{2}\right), 5.23\left(\mathrm{~d}, J=1.0 \mathrm{~Hz}, 1 \mathrm{H}, \mathrm{C}=\mathrm{CH}_{2}\right) .{ }^{13} \mathbf{C}$ NMR $(101$ $\left.\mathrm{MHz}, \mathrm{CDCl}_{3}\right) \delta 172.4,149.6,143.7,141.0,132.5,131.7,130.8,129.6,128.20,127.8,127.6$, 127.0, 114.5. NMR data correspond to the reported values. ${ }^{[10]}$ 


\section{2-(1-(4-Fluorophenyl)vinyl)benzoic acid (1i)}<smiles>C=C(c1ccc(F)cc1)c1ccccc1C(=O)O</smiles>

According to the general procedure, starting from 2-(4-fluorobenzoyl)benzoic acid 24 (1.50 g, 6.14 mmol, 1.0 equiv.), tBuOK (1.79 g, 15.9 mmol, 2.6 equiv.) and bromo(methyl)triphenylphosphorane ( $2.85 \mathrm{~g}, 7.98 \mathrm{mmol}, 1.3$ equiv.), the product was obtained as a white solid (0.25 g, $1.0 \mathrm{mmol}, 17 \%$ yield). ${ }^{1} \mathbf{H}$ NMR $\left(400 \mathrm{MHz}, \mathrm{CDCl}_{3}\right) \delta 7.93(\mathrm{dd}, J=7.8,1.5$ $\mathrm{Hz}, 1 \mathrm{H}, \operatorname{Ar} H), 7.57(\mathrm{td}, J=7.5,1.4 \mathrm{~Hz}, 1 \mathrm{H}, \operatorname{Ar} H), 7.44(\mathrm{td}, J=7.6,1.4 \mathrm{~Hz}, 1 \mathrm{H}, \operatorname{Ar} H), 7.36(\mathrm{dd}, J$ $=7.6,1.3 \mathrm{~Hz}, 1 \mathrm{H}, \operatorname{Ar} H), 7.21-7.12(\mathrm{~m}, 2 \mathrm{H}, \operatorname{Ar} H), 6.97-6.85(\mathrm{~m}, 2 \mathrm{H}, \operatorname{Ar} H), 5.60(\mathrm{~d}, J=0.9$ $\left.\mathrm{Hz}, 1 \mathrm{H}, \mathrm{C}=\mathrm{CH}_{2}\right), 5.20\left(\mathrm{~s}, 1 \mathrm{H}, \mathrm{C}=\mathrm{CH}_{2}\right) .{ }^{13} \mathbf{C} \mathbf{~ N M R}\left(101 \mathrm{MHz}, \mathrm{CDCl}_{3}\right) \delta 172.7,162.4(\mathrm{~d}, J=246.6$ $\mathrm{Hz}), 148.7,143.6,137.3(\mathrm{~d}, J=3.3 \mathrm{~Hz}), 132.7,131.6,130.9,129.5,128.5(\mathrm{~d}, J=8.0 \mathrm{~Hz}), 128.0$ $115.0(\mathrm{~d}, J=21.5 \mathrm{~Hz}), 114.3$. NMR data correspond to the reported values. ${ }^{[13]}$

\section{2,2-Dimethyl-4-phenylpent-4-enoic acid (1j)}

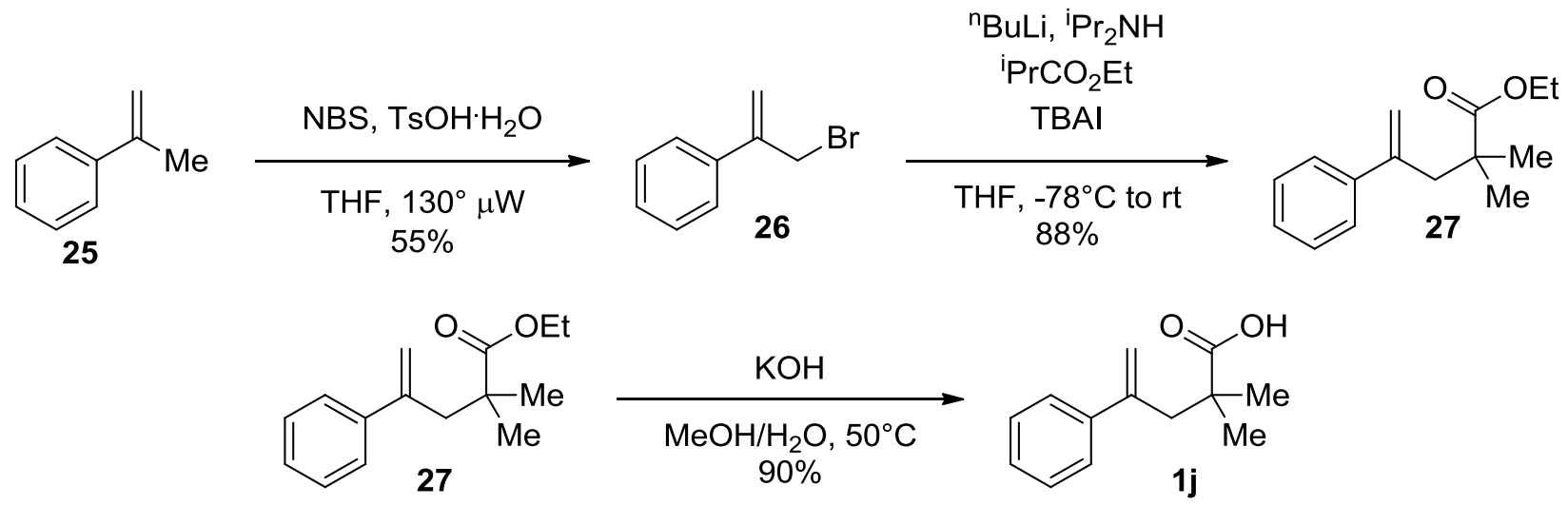

Following a modified version of a reported procedure, ${ }^{[14]} \mathrm{N}$-Bromosuccinimide $(2.46 \mathrm{~g}, 13.8$ mmol, 2.0 equiv.) and $p$-toluenesulfonic acid hydrate $(0.263 \mathrm{~g}, 1.38 \mathrm{mmol}, 0.2$ equiv.) were dissolved in dry THF $(20 \mathrm{~mL})$, giving a yellow solution. Alpha methyl styrene 25 (0.90 mL, 6.9 mmol, 1.0 equiv) was added via syringe: the reaction mixture became colorless. The latter was then submitted to irradiation in a microwave reactor at $130{ }^{\circ} \mathrm{C}$ for $3 \mathrm{~h}$. The mixture was then allowed to cool down to room temperature and poured into pentane. A solid immediately precipitated. The organic layer was washed with water $(4 \times 20 \mathrm{~mL})$ and brine (once), finally becoming a clear solution. The latter was dried over $\mathrm{MgSO}_{4}$, filtered and concentrated in vacuo to provide a yellow oil. The latter was submitted to column chromatography $\left(\mathrm{SiO}_{2}\right.$, pentane, $(\mathrm{Rf}=$ $0.95)$ ) to provide pure (3-bromoprop-1-en-2-yl)benzene 26 ( $0.750 \mathrm{~g}, 3.81 \mathrm{mmol}, 55 \%$ yield) as a colorless oil. ${ }^{1} \mathbf{H}$ NMR $\left(400 \mathrm{MHz}, \mathrm{CDCl}_{3}\right) \delta 7.52-7.48(\mathrm{~m}, 2 \mathrm{H}, \mathrm{ArH}), 7.41-7.33(\mathrm{~m}, 3 \mathrm{H}, \mathrm{ArH})$, $5.56\left(\mathrm{~s}, 1 \mathrm{H}, \mathrm{C}=\mathrm{CH}_{2}\right), 5.50\left(\mathrm{~s}, 1 \mathrm{H}, \mathrm{C}=\mathrm{CH}_{2}\right), 4.39\left(\mathrm{~s}, 2 \mathrm{H}, \mathrm{CH}_{2}\right)$. NMR data correspond to the reported values. ${ }^{[14]}$ Following a standard procedure, diisopropylamine (freshly distilled over $\mathrm{CaH}_{2} ; 0.50 \mathrm{~mL}, 3.5 \mathrm{mmol}, 1.1$ equiv.) was dissolved in dry THF $(3.2 \mathrm{~mL})$ and the resulting 
solution was cooled to $-78{ }^{\circ} \mathrm{C}$ (dry ice-acetone bath). $n \mathrm{BuLi}(2.5 \mathrm{M}$ in hexane; $1.3 \mathrm{~mL}, 3.3 \mathrm{mmol}$, 1.05 equiv.) was added dropwise at the same temperature. The mixture was then stirred at $0{ }^{\circ} \mathrm{C}$ for $40 \mathrm{~min}$, before being cooled back to $-78{ }^{\circ} \mathrm{C}$. Ethyl isobutyrate $(0.44 \mathrm{~mL}, 3.2 \mathrm{mmol}, 1.0$ equiv.) was added dropwise to the so-obtained LDA solution and the resulting mixture was stirred at $-78{ }^{\circ} \mathrm{C}$ for $1 \mathrm{~h}$ and then treated with tetrabutylammonium iodide $(0.234 \mathrm{~g}, 0.634 \mathrm{mmol}$, 0.20 equiv.) and (3-bromoprop-1-en-2-yl)benzene 26 ( $0.750 \mathrm{~g}, 3.81 \mathrm{mmol}, 1.2$ equiv.). After 30 min, the mixture was warmed to room temperature and stirred for another $15 \mathrm{~h}$. After this time, the mixture was diluted with $\mathrm{Et}_{2} \mathrm{O}$ and the reaction was quenched by addition of water. The aqueous layer was extracted with $\mathrm{Et}_{2} \mathrm{O}(3 \mathrm{x} 10 \mathrm{~mL})$ and the combined organic extracts were washed with brine (once), dried over $\mathrm{MgSO}_{4}$, filtered and concentrated in vacuo. The resulting crude oil was submitted to column chromatography $\left(\mathrm{SiO}_{2}\right.$; pentane/EtOAc 24/1) to provide pure ethyl 2,2-dimethyl-4-phenylpent-4-enoate $27(0.650 \mathrm{~g}, 2.80 \mathrm{mmol}, 88 \%$ yield $)$ ( $\mathrm{R}_{\mathrm{f}} 0.80$ Pentane/EtOAc 5/1) as a colorless oil. ${ }^{1} \mathbf{H}$ NMR $\left(400 \mathrm{MHz}, \mathrm{CDCl}_{3}\right) \delta 7.35-7.20(\mathrm{~m}, 5 \mathrm{H}, \mathrm{ArH})$, $5.22\left(\mathrm{~d}, J=1.7 \mathrm{~Hz}, 1 \mathrm{H}, \mathrm{C}=\mathrm{CH}_{2}\right), 5.04\left(\mathrm{~m}, 1 \mathrm{H}, \mathrm{C}=\mathrm{CH}_{2}\right), 3.73\left(\mathrm{q}, J=7.1 \mathrm{~Hz}, 2 \mathrm{H}, \mathrm{CH}_{2} \mathrm{CH}_{3}\right), 2.79$ $\left(\mathrm{s}, 2 \mathrm{H}, \mathrm{CH}_{2}\right), 1.16-1.07\left(\mathrm{~m}, 9 \mathrm{H}, \mathrm{CH}_{2} \mathrm{CH}_{3}+\mathrm{CMe}_{2}\right)$. NMR data correspond to the reported values. $^{[15]}$ Following a standard procedure, ethyl 2,2-dimethyl-4-phenylpent-4-enoate 27 (0.466 $\mathrm{g}, 2.01 \mathrm{mmol}, 1.0$ equiv.) was dissolved in $\mathrm{MeOH}(4.0 \mathrm{~mL})$. The solution was cooled to $0{ }^{\circ} \mathrm{C}$ (ice/water bath) and a solution of $\mathrm{KOH}(0.56 \mathrm{~g}, 10 \mathrm{mmol}, 5.0$ equiv.) in water $(0.80 \mathrm{~mL})$ was slowly added. The cooling bath was removed and stirring was continued while heating the mixture at $50{ }^{\circ} \mathrm{C}$ for $3 \mathrm{~h}$. During this time, the initial suspension converted into a pale yellow clear solution. The latter was then diluted with water and extracted with ether $(2 \mathrm{x} 20 \mathrm{~mL})$. It was then acidified with concentrated aq. $\mathrm{HCl}$ until acidic $\mathrm{pH}$ and extracted with $\mathrm{DCM}(3 \times 20 \mathrm{~mL})$. The combined organic extracts were washed with brine, dried $\mathrm{MgSO}_{4}$, and concentrated in vacuo to provide pure 2,2-dimethyl-4-phenylpent-4-enoic acid $\mathbf{1 j}(0.370,1.81 \mathrm{mmol}, 90 \%$ yield) as an off-white oil, which became a pale pink crystalline solid on standing. ${ }^{1} \mathbf{H}$ NMR (400 MHz, $\left.\mathrm{CDCl}_{3}\right) \delta 11.10\left(\mathrm{~s}, 1 \mathrm{H}, \mathrm{CO}_{2} \mathrm{H}\right), 7.35(\mathrm{~m}, 2 \mathrm{H}, \mathrm{ArH}), 7.32$ - $7.22(\mathrm{~m}, 3 \mathrm{H}, \mathrm{ArH}), 5.27(\mathrm{~d}, J=1.4 \mathrm{~Hz}$, $\left.1 \mathrm{H}, \mathrm{C}=\mathrm{CH}_{2}\right), 5.10\left(\mathrm{~s}, 1 \mathrm{H}, \mathrm{C}=\mathrm{CH}_{2}\right), 2.82\left(\mathrm{~s}, 2 \mathrm{H}, \mathrm{CH}_{2}\right), 1.10\left(\mathrm{~s}, 6 \mathrm{H}, \mathrm{CMe}_{2}\right) .{ }^{13} \mathrm{C} \mathbf{N M R}(101 \mathrm{MHz}$, $\left.\mathrm{CDCl}_{3}\right) \delta 184.5,145.9,142.4,128.2,127.5,126.8,117.3,45.3,42.8,25.2$. NMR data correspond to the reported values. ${ }^{[10]}$

\section{4-(Thiophen-3-yl)pent-4-enoic acid (1k)}

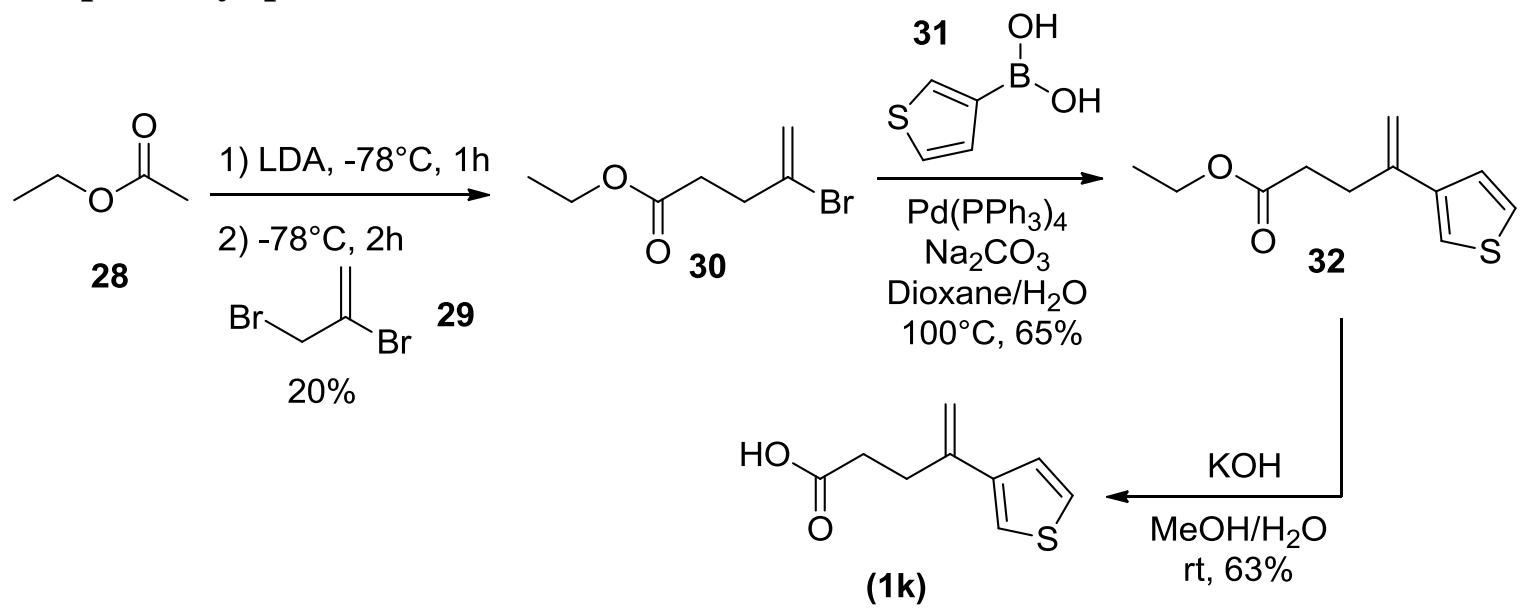

Under nitrogen, to a solution of ethyl acetate $28(1.9 \mathrm{~mL}, 20 \mathrm{mmol}, 1.1$ equiv.) in $50 \mathrm{~mL}$ of dry THF was added lithium diisopropylamide (2 M solution in THF, $10.0 \mathrm{~mL}, 20.0 \mathrm{mmol}, 1.1$ equiv.) 
dropwise and the reaction was stirred at $-78{ }^{\circ} \mathrm{C}$ for $1 \mathrm{~h}$. To the reaction was added 2,3dibromoprop-1-ene 29 ( $2.10 \mathrm{~mL}, 18.2 \mathrm{mmol}, 1.0$ equiv.) and the reaction was stirred for an additional $2 \mathrm{~h}$ at $-78{ }^{\circ} \mathrm{C}$. The reaction was warmed at $\mathrm{rt}$ and water $(20 \mathrm{~mL})$ was added slowly. The crude product was extracted with EtOAc three times $(3 \times 20 \mathrm{~mL})$. The combined organic extracts were washed with brine, dried over $\mathrm{MgSO}_{4}$, filtered, and concentrated under reduced pressure. The resulting oil was purified by $\mathrm{SiO}_{2}$ column chromatography (Pentane/AcOEt : 100/0 to 95/5 to 9/1) to give ethyl 4-bromopent-4-enoate 30 (0.770 g, $3.72 \mathrm{mmol}, 20 \%$ yield). 1 H NMR (400 $\left.\mathrm{MHz}, \mathrm{CDCl}_{3}\right) \delta 5.63\left(\mathrm{~s}, 1 \mathrm{H}, \mathrm{C}=\mathrm{CH}_{2}\right), 5.43\left(\mathrm{~s}, 1 \mathrm{H}, \mathrm{C}=\mathrm{CH}_{2}\right), 4.13\left(\mathrm{t}, J=7.2 \mathrm{~Hz}, 2 \mathrm{H}, \mathrm{CH}_{2} \mathrm{CH}_{3}\right)$, $2.75\left(\mathrm{t}, J=7.5 \mathrm{~Hz}, 2 \mathrm{H}, \mathrm{CH}_{2} \mathrm{CO}_{2} \mathrm{Et}\right), 2.57\left(\mathrm{t}, J=7.5 \mathrm{~Hz}, 2 \mathrm{H}, C_{2}\right), 1.26(\mathrm{t}, J=7.2 \mathrm{~Hz}, 3 \mathrm{H}$, $\mathrm{CH}_{2} \mathrm{CH}_{3}$ ). NMR data correspond to the reported values. ${ }^{[16]}$ Following a reported procedure, ${ }^{[1]]}$ tetrakis palladium $(0.127 \mathrm{~g}, 0.110 \mathrm{mmol}, 5 \mathrm{~mol} \%)$, sodium carbonate (anhydrous; $0.513 \mathrm{~g}, 4.84$ mmol. 2.2 equiv.), and thiophen-3-ylboronic acid 31 (0.338 g, $2.64 \mathrm{mmol}, 1.2$ equiv.) were suspended in a 7/1 mixture of dioxane $(15.4 \mathrm{~mL})$ and water $(2.2 \mathrm{~mL})$. Ethyl 4-bromopent-4enoate 30 ( $0.456 \mathrm{~g}, 2.20 \mathrm{mmol}, 1.0$ equiv.) was then added by syringe and the resulting yellowbrown mixture was stirred under heating at $100{ }^{\circ} \mathrm{C}$ overnight. After $16 \mathrm{~h}$, the reaction mixture was allowed to cool down to room temperature. The solvents were removed under reduced pressure and the residue was dissolved in EtOAc $(30 \mathrm{~mL})$. The organic solution was washed with water. The aqueous layer was then extracted with EtOAc $(3 \times 25 \mathrm{~mL})$ and the combined extracts were washed with brine, dried over $\mathrm{MgSO}_{4}$, filtered and concentrated in vacuo. The resulting crude product was submitted to column chromatography $\left(\mathrm{SiO}_{2}\right.$, pentane/EtOAc 24.6/0.4 to 24/1) to afford ethyl 4-(thiophen-3-yl)pent-4-enoate $32(90 \%$ pure, $0.327 \mathrm{~g}, 1.40 \mathrm{mmol}, 65 \%$ yield) as a pale yellow oil. ${ }^{1} \mathbf{H}$ NMR $\left(400 \mathrm{MHz}, \mathrm{CDCl}_{3}\right) \delta 7.31-7.29(\mathrm{~m}, 2 \mathrm{H}, \mathrm{ArH}), 7.26(\mathrm{~d}, J=3.9 \mathrm{~Hz}, 1 \mathrm{H}$, $\mathrm{ArH}), 5.40\left(\mathrm{~s}, 1 \mathrm{H}, \mathrm{C}=\mathrm{CH}_{2}\right), 5.06\left(\mathrm{~s}, 1 \mathrm{H}, \mathrm{C}=\mathrm{CH}_{2}\right), 4.16\left(\mathrm{q}, \mathrm{J}=7.1 \mathrm{~Hz}, 2 \mathrm{H}, \mathrm{OCH}_{2} \mathrm{CH}_{3}\right), 2.81(\mathrm{~m}$, $\left.2 \mathrm{H}, \mathrm{CH}_{2}\right), 2.58\left(\mathrm{~m}, 2 \mathrm{H}, \mathrm{CH}_{2}\right), 1.28\left(\mathrm{t}, \mathrm{J}=7.1 \mathrm{~Hz}, 3 \mathrm{H}, \mathrm{OCH}_{2} \mathrm{CH}_{3}\right)$. NMR data correspond to the reported values. ${ }^{[11]}$ Following a standard procedure, ethyl 4-(thiophen-3-yl)pent-4-enoate 32 (0.327 g, $1.55 \mathrm{mmol}, 1.0$ equiv.) was dissolved in $\mathrm{MeOH}(3.1 \mathrm{~mL})$. The solution was cooled to 0 ${ }^{\circ} \mathrm{C}$ and a solution of $\mathrm{KOH}(0.44 \mathrm{~g}, 7.8 \mathrm{mmol}, 5.0$ equiv. $)$ in water $(0.6 \mathrm{~mL})$ was slowly added. The cooling bath was removed and stirring was continued at room temperature for 2 hours. The latter was then diluted with water and extracted with ether $(3 \times 20 \mathrm{~mL})$. It was then acidified with concentrated aq. $\mathrm{HCl}$ until acidic $\mathrm{pH}$ and extracted with DCM $(3 \times 20 \mathrm{~mL})$. The combined organic extracts were washed with brine, dried $\mathrm{MgSO}_{4}$, and concentrated in vacuo to provide a crude solid. The latter was submitted to recrystallization from hexane/chloroform $(10 / 1,5 \mathrm{~mL})$ to afford 4-(Thiophen-3-yl)pent-4-enoic acid (1k) (90\% pure, $0.200 \mathrm{~g}, 0.988 \mathrm{mmol}, 63 \%$ yield) as an off-white solid. ${ }^{1} \mathbf{H}$ NMR $\left(400 \mathrm{MHz} \mathrm{CDCl}_{3}\right) \delta 11.00$ (br s, $\left.1 \mathrm{H}, \mathrm{COOH}\right), 7.29$ (m, 1H, ArH), $7.23(\mathrm{~d}, J=4.1 \mathrm{~Hz}, 2 \mathrm{H}, \mathrm{ArH}), 5.40\left(\mathrm{~s}, 1 \mathrm{H}, \mathrm{C}=\mathrm{CH}_{2}\right), 5.06\left(\mathrm{~s}, 1 \mathrm{H}, \mathrm{C}=\mathrm{CH}_{2}\right), 2.81\left(\mathrm{~m}, 2 \mathrm{H}, \mathrm{CH}_{2}\right)$, $2.62\left(\mathrm{~m}, 2 \mathrm{H}, \mathrm{CH}_{2}\right) .{ }^{13} \mathbf{C} \mathbf{N M R}\left(101 \mathrm{MHz}, \mathrm{CDCl}_{3}\right) \delta 179.9,141.9,141.0,125.9,125.8,120.6$, 111.6, 33.1, 30.1. NMR data correspond to the reported values. ${ }^{[11]}$

\section{4-(2,5-Dimethylphenyl)pent-4-enoic acid (11)}

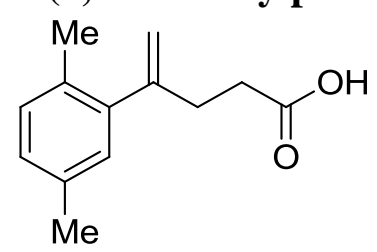

According to the general procedure, starting from 4-(2,5-dimethylphenyl)-4-oxobutanoic acid 18e (1.55 g, 7.54 mmol, 1.0 equiv.), tBuOK (2.20 g, $19.6 \mathrm{mmol}, 2.6$ equiv.) and 
bromo(methyl)triphenylphosphorane ( $3.50 \mathrm{~g}, 9.80 \mathrm{mmol}, 1.3$ equiv.), the product was obtained as a beige solid (1.25 g, $5.87 \mathrm{mmol}, 78 \%$ yield). Two rotamers are observed in NMR analysis. Only the major rotamer is described ${ }^{1} \mathbf{H}$ NMR $\left(400 \mathrm{MHz}, \mathrm{CDCl}_{3}\right) \delta 7.06(\mathrm{~d}, J=7.7 \mathrm{~Hz}, 1 \mathrm{H}, \operatorname{Ar} H)$, $7.01-6.95(\mathrm{~m}, 1 \mathrm{H}, \mathrm{ArH}), 6.89(\mathrm{~d}, J=1.8 \mathrm{~Hz}, 1 \mathrm{H}, \mathrm{ArH}), 5.21\left(\mathrm{~d}, J=1.7 \mathrm{~Hz}, 1 \mathrm{H}, \mathrm{C}=\mathrm{CH}_{2}\right), 4.91$ $\left(\mathrm{d}, J=1.7 \mathrm{~Hz}, 1 \mathrm{H} \mathrm{C}=\mathrm{CH}_{2}\right), 2.66\left(\mathrm{t}, J=7.7 \mathrm{~Hz}, 2 \mathrm{H}, \mathrm{CH}_{2} \mathrm{CH}_{2} \mathrm{CO}_{2} \mathrm{H}\right), 2.47(\mathrm{t}, J=7.8 \mathrm{~Hz}, 2 \mathrm{H}$, $\left.\mathrm{CH}_{2} \mathrm{CH}_{2} \mathrm{CO}_{2} \mathrm{H}\right), 2.30\left(\mathrm{~s}, 3 \mathrm{H}, \mathrm{CH}_{3}\right), 2.24\left(\mathrm{~s}, 3 \mathrm{H}, \mathrm{CH}_{3}\right) .{ }^{13} \mathbf{C}$ NMR $\left(101 \mathrm{MHz}, \mathrm{CDCl}_{3}\right) \delta 179.8$, 148.1, 141.9, 135.0, 131.8, 130.2, 129.1, 127.9, 114.5, 32.6, 32.6, 21.0, 19.4. IR 3079 (w), 2979 (w), 2922 (w), 1708 (s), 1639 (w), 1499 (w), 1436 (w), 1295 (w), 1214 (w), 1159 (w), 916 (w). HRMS (ESI) calcd for $\mathrm{C}_{13} \mathrm{H}_{17} \mathrm{O}_{2}{ }^{+}[\mathrm{M}+\mathrm{H}]^{+}$205.1223; found 205.1228. Melting point : $82{ }^{\circ} \mathrm{C}$.

\section{2-(1-Methylene-2,3-dihydro-1H-inden-2-yl)acetic acid (1m)}

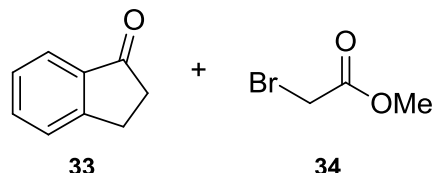

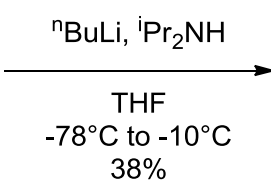

$38 \%$

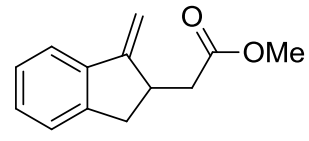

36
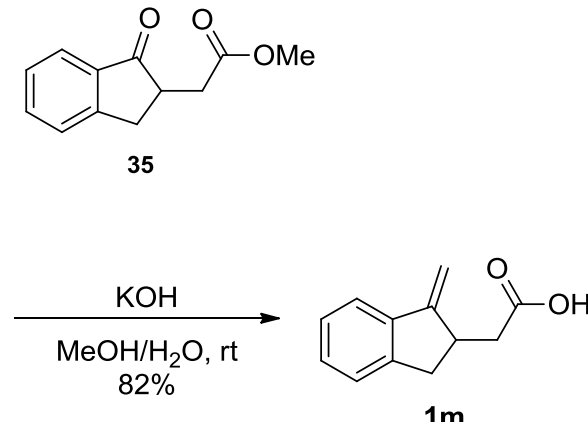

Under nitrogen, diisopropylamine (freshly distilled from $\mathrm{CaH}_{2} ; 1.12 \mathrm{~mL}, 7.94$ mmol, 1.05 equiv.) was dissolved in dry THF $(5.0 \mathrm{~mL})$. The solution was cooled down to $-70{ }^{\circ} \mathrm{C}$ and $n \mathrm{BuLi}(2.5 \mathrm{M}$ in hexanes; $3.0 \mathrm{~mL}, 7.6 \mathrm{mmol}, 1.0$ equiv.) was added dropwise at the same temperature. Upon completing the addition, the resulting pale yellow solution was allowed to warm to $0{ }^{\circ} \mathrm{C}$ for 15 min. It was then cooled back to $-78{ }^{\circ} \mathrm{C}$ and added dropwise to a solution of 1-indanone $\mathbf{3 3}$ (1.00 $\mathrm{g}, 7.57 \mathrm{mmol}, 1.0$ equiv.) in dry THF $(24 \mathrm{~mL})$. The mixture was stirred at $-78{ }^{\circ} \mathrm{C}$ for $40 \mathrm{~min}$. A solution of methyl bromoacetate $34(0.76 \mathrm{~mL}, 7.9 \mathrm{mmol}, 1.05$ equiv.) in dry THF (6.0 mL) was then added dropwise. The resulting pale yellow solution was stirred overnight while allowing it to warm to room temperature. After $20 \mathrm{~h}$, the mixture looked like a yellow clear solution. The reaction was quenched by addition of water, followed by sat. aq. $\mathrm{NH}_{4} \mathrm{Cl}$. The aqueous layer was extracted with ether $(3 \times 30 \mathrm{~mL})$ and the combined extracts were washed with water and brine, dried over $\mathrm{MgSO}_{4}$, filtered and concentrated in vacuo. The obtained crude oil was submitted to column chromatography $\left(\mathrm{SiO}_{2}\right.$, pentane/EtOAc 24/1) to afford the pure methyl 2-(1-oxo-2,3dihydro- $1 H$-inden-2-yl)acetate $35(0.593 \mathrm{~g}, 2.90 \mathrm{mmol}, 38 \%$ yield $)$ as a pale yellow oil. $\mathrm{R}_{\mathrm{f}} 0.85$ (Pentane/EtOAc 5/1) ${ }^{1} \mathbf{H}$ NMR $\left(400 \mathrm{MHz} \mathrm{CDCl}_{3}\right) \delta 7.77(\mathrm{~d}, J=7.7 \mathrm{~Hz}, 1 \mathrm{H}, \mathrm{ArH}), 7.60(\mathrm{t}, J=$ $7.4 \mathrm{~Hz}, 1 \mathrm{H}, \operatorname{Ar} H), 7.46(\mathrm{~d}, J=7.7 \mathrm{~Hz}, 1 \mathrm{H}, \operatorname{ArH}), 7.38(\mathrm{t}, J=7.4 \mathrm{~Hz}, 1 \mathrm{H}, \operatorname{ArH}), 3.69$ (s, 3H, $\left.\mathrm{OCH}_{3}\right), 3.47\left(\mathrm{dd}, J=17.1,8.0 \mathrm{~Hz}, 1 \mathrm{H}, \mathrm{CH}_{2}\right), 3.08-2.95\left(\mathrm{~m}, 2 \mathrm{H}, \mathrm{CH}_{2}\right.$ and $\left.C H C O\right), 2.89(\mathrm{dd}, J=$ 17.1, $\left.4.4 \mathrm{~Hz}, 1 \mathrm{H}, \mathrm{CH}_{2}\right), 2.62\left(\mathrm{dd}, \mathrm{J}=9.1,17.1 \mathrm{~Hz}, 1 \mathrm{H}, \mathrm{CH}_{2}\right)$. NMR data correspond to the reported values. ${ }^{[17]}$ Following a standard procedure, potassium tert-butoxide $(0.652 \mathrm{~g}, 5.81 \mathrm{mmol}$, 2.0 equiv.) was suspended in dry THF $(14.5 \mathrm{~mL})$. The suspension was cooled to $0{ }^{\circ} \mathrm{C}$ and methyltriphenylphosphonium bromide $(2.18 \mathrm{~g}, 6.10 \mathrm{mmol}, 2.1$ equiv.) was added, leading to the formation of a bright yellow suspension. The latter was stirred at $0{ }^{\circ} \mathrm{C}$ for $30 \mathrm{~min}$. A solution of methyl 2-(1-oxo-2,3-dihydro-1H-inden-2-yl)acetate 35 (0.593 g, $2.90 \mathrm{mmol}, 1.0$ equiv.) in dry THF $(1.0 \mathrm{~mL})$ was then added at the same temperature. The reaction mixture was allowed to warm to room temperature and stirred overnight. The reaction was quenched by addition of sat. aq. $\mathrm{NH}_{4} \mathrm{Cl}$ at $0{ }^{\circ} \mathrm{C}$. The aqueous layer was extracted with $\mathrm{Et}_{2} \mathrm{O}(3 \times 15 \mathrm{~mL})$ and the combined 
organic extracts were washed with brine, dried over $\mathrm{MgSO}_{4}$, filtered and concentrated in vacuo to give a yellow crude solid. The latter was submitted to column chromatography $\left(\mathrm{SiO}_{2}\right.$, pentane/EtOAc 24/1 to 23/2) $(\mathrm{Rf}=0.35$ Pentane/EtOAc : $9 / 1)$ to afford pure compound $36(0.257$ g, $1.27 \mathrm{mmol}, 44 \%$ yield) as a pale yellow oil. ${ }^{1} \mathbf{H}$ NMR $\left(400 \mathrm{MHz}, \mathrm{CDCl}_{3}\right) \delta 7.48(\mathrm{~d}, J=6.8 \mathrm{~Hz}$, $1 \mathrm{H}, \mathrm{ArH}), 7.23-7.19(\mathrm{~m}, 3 \mathrm{H}, \mathrm{ArH}), 5.51\left(\mathrm{~d}, \mathrm{~J}=1.4 \mathrm{~Hz}, 1 \mathrm{H}, \mathrm{C}=\mathrm{CH}_{2}\right), 5.00\left(\mathrm{~s}, 1 \mathrm{H}, \mathrm{C}=\mathrm{CH}_{2}\right), 3.71$ $\left(\mathrm{s}, 3 \mathrm{H}, \mathrm{OCH}_{3}\right), 3.43(\mathrm{~m}, 1 \mathrm{H}, \mathrm{CH}), 3.28\left(\mathrm{dd}, J=8.4,16.4 \mathrm{~Hz}, 1 \mathrm{H}, \mathrm{CH}_{2}\right), 2.73\left(\mathrm{~m}, 1 \mathrm{H}, \mathrm{CH}_{2}\right), 2.69$ (m, $\left.1 \mathrm{H}, \mathrm{CH}_{2}\right), 2.46\left(\mathrm{dd}, \mathrm{J}=9.6,15.7 \mathrm{~Hz}, 1 \mathrm{H}, \mathrm{CH}_{2}\right)$. Following a standard procedure, methyl 2(1-methylene-2,3-dihydro- $1 H$-inden-2-yl)acetate $36(0.257 \mathrm{~g}, 1.27 \mathrm{mmol}, 1.0$ equiv.) was dissolved in $\mathrm{MeOH}(2.6 \mathrm{~mL})$. The solution was cooled to $0{ }^{\circ} \mathrm{C}$ and a solution of $\mathrm{KOH}(0.36 \mathrm{~g}, 6.3$ mmol, 5.0 equiv. $)$ in water $(0.5 \mathrm{~mL})$ was slowly added. The cooling bath was removed and stirring was continued at room temperature for 2 hours. During this time, the initial suspension converted into a pale yellow clear solution. The latter was then diluted with water and extracted with ether $(3 \times 10 \mathrm{~mL})$. It was then acidified with concentrated aq. $\mathrm{HCl}$ until acidic $\mathrm{pH}$ and extracted with DCM $(3 \times 10 \mathrm{~mL})$. The combined organic extracts were washed with brine, dried $\mathrm{MgSO}_{4}$, concentrated in vacuo to provide pure 2-(1-methylene-2,3-dihydro- $1 H$-inden-2-yl)acetic

acid (1m) (90\% pure, $0.195 \mathrm{~g}, 1.04 \mathrm{mmol}, 82 \%$ yield) as a colorless oil. ${ }^{1} \mathbf{H}$ NMR (400 MHz, $\left.\mathrm{CDCl}_{3}\right) \delta 9.88\left(\right.$ br s, $\left.1 \mathrm{H}, \mathrm{CO}_{2} H\right), 7.51(\mathrm{~d}, J=6.8 \mathrm{~Hz}, 1 \mathrm{H}, \mathrm{ArH}), 7.35-7.17(\mathrm{~m}, 3 \mathrm{H}, \mathrm{ArH}), 5.56$ $\left(\mathrm{s}, 1 \mathrm{H}, \mathrm{C}=\mathrm{CH}_{2}\right), 5.06\left(\mathrm{~s}, 1 \mathrm{H}, \mathrm{C}=\mathrm{CH}_{2}\right), 3.42\left(\mathrm{~d}, J=9.7 \mathrm{~Hz}, 1 \mathrm{H}, \mathrm{CH}\right.$ or $\left.\mathrm{ArCH}_{2}\right), 3.34(\mathrm{dd}, J=16.3$, $\left.8.5 \mathrm{~Hz}, 1 \mathrm{H}, \mathrm{CH}_{2} \mathrm{CO}\right), 2.80\left(\mathrm{~d}, J=5.4 \mathrm{~Hz}, 1 \mathrm{H}, \mathrm{CH}\right.$ or $\left.\mathrm{ArCH}_{2}\right), 2.78(\mathrm{~d}, J=6.0 \mathrm{~Hz}, 1 \mathrm{H}, \mathrm{CH}$ or $\left.\mathrm{ArCH}_{2}\right), 2.53\left(\mathrm{dd}, J=16.1,9.6 \mathrm{~Hz}, 1 \mathrm{H}, \mathrm{CH}_{2} \mathrm{CO}\right) .{ }^{13} \mathbf{C} \mathbf{N M R}\left(101 \mathrm{MHz}, \mathrm{CDCl}_{3}\right) \delta 178.9,152.8$, 144.3, 140.2, 128.9, 126.9, 125.5, 121.0, 103.4, 40.2, 39.3, 37.4. IR 3519 (w), 2923 (s), 2852 (m), $2851(\mathrm{~m}), 2360(\mathrm{w}), 2360(\mathrm{w}), 2343$ (w), 2342 (w), 1741 (s), $1639(\mathrm{w}), 1439(\mathrm{~m}), 1411(\mathrm{~m})$, $1303(\mathrm{~m}), 1280(\mathrm{~m}), 1257(\mathrm{~m}), 1211(\mathrm{~m}), 1210(\mathrm{~m}), 957(\mathrm{w}), 875(\mathrm{~m})$. HRMS (ESI) calcd for $\mathrm{C}_{12} \mathrm{H}_{11} \mathrm{O}_{2}^{+}[\mathrm{M}+]$ 187.0759; found 187.0760.

\section{4-Methylene-6-phenylhex-5-ynoic acid (1n)}

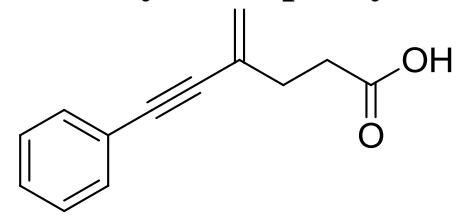

According to the general procedure, starting from 4-oxo-6-phenylhex-5-ynoic acid $22(0.50 \mathrm{~g}, 2.4$ mmol, 1.0 equiv.), tBuOK $(0.721 \mathrm{~g}, \quad 6.43 \mathrm{mmol}, 2.6$ equiv.) and bromo(methyl)triphenylphosphorane (1.15 g, $3.21 \mathrm{mmol}, 1.3$ equiv.), the product was obtained as a brown solid $(0.35 \mathrm{~g}, 1.8 \mathrm{mmol}, 71 \%$ yield $) .{ }^{1} \mathbf{H} \mathbf{~ N M R}\left(400 \mathrm{MHz}, \mathrm{CDCl}_{3}\right) \delta 7.48-7.41(\mathrm{~m}, 2 \mathrm{H}$, $\mathrm{ArH}), 7.35-7.29(\mathrm{~m}, 3 \mathrm{H}, \mathrm{ArH}), 5.47\left(\mathrm{~d}, J=1.5 \mathrm{~Hz}, 1 \mathrm{H}, \mathrm{C}=\mathrm{CH}_{2}\right), 5.38(\mathrm{~d}, J=1.4 \mathrm{~Hz}, 1 \mathrm{H}$, $\mathrm{C}=\mathrm{CH}_{2}$ ), 2.68 (ddd, $\left.J=8.4,7.0,1.7 \mathrm{~Hz}, 2 \mathrm{H}, \mathrm{CH}_{2} \mathrm{CH}_{2} \mathrm{CO}_{2} \mathrm{H}\right), 2.63-2.54(\mathrm{~m}, 2 \mathrm{H}$, $\left.\mathrm{CH}_{2} \mathrm{CH}_{2} \mathrm{CO}_{2} \mathrm{H}\right) .{ }^{13} \mathrm{C}$ NMR $\left(101 \mathrm{MHz}, \mathrm{CDCl}_{3}\right) \delta 179.2,131.7,129.6,128.4,128.5,123.0,122.3$, $90.2,88.7,33.0,32.1$. NMR data correspond to the reported values. ${ }^{[18]}$

\section{5-Phenylhex-5-enoic acid (10)}<smiles>C=C(CCCC(=O)O)c1ccccc1</smiles>

According to the general procedure, starting from 5-oxo-5-phenylpentanoic acid (1.50 g, 7.80 mmol, 1.0 equiv.), tBuOK (2.28 g, $20.3 \quad \mathrm{mmol}, 2.6 \quad$ equiv.) and 
bromo(methyl)triphenylphosphorane (3.62 g, $10.1 \mathrm{mmol}, 1.3$ equiv.), the product was obtained as a white solid (0.40 g, $2.1 \mathrm{mmol}, 27 \%$ yield). ${ }^{1} \mathbf{H}$ NMR $\left(400 \mathrm{MHz}, \mathrm{CDCl}_{3}\right) \delta 7.45-7.41(\mathrm{~m}, 2 \mathrm{H}$, $\mathrm{ArH}), 7.38-7.33(\mathrm{~m}, 2 \mathrm{H}, \mathrm{ArH}), 7.32-7.27(\mathrm{~m}, 1 \mathrm{H}, \mathrm{ArH}), 5.35\left(\mathrm{~d}, J=1.3 \mathrm{~Hz}, 1 \mathrm{H}, \mathrm{C}=\mathrm{CH}_{2}\right)$, $5.12\left(\mathrm{~d}, J=1.4 \mathrm{~Hz}, 1 \mathrm{H}, \mathrm{C}=\mathrm{CH}_{2}\right), 2.61\left(\mathrm{td}, J=7.5,1.2 \mathrm{~Hz}, 2 \mathrm{H}, \mathrm{CH}_{2} \mathrm{CH}_{2} \mathrm{CH}_{2} \mathrm{CO}_{2} \mathrm{H}\right), 2.41(\mathrm{t}, J=$ $\left.7.4 \mathrm{~Hz}, 2 \mathrm{H}, \mathrm{CH}_{2} \mathrm{CH}_{2} \mathrm{CH}_{2} \mathrm{CO}_{2} \mathrm{H}\right), 1.83\left(\mathrm{p}, \mathrm{J}=7.5 \mathrm{~Hz}, 2 \mathrm{H}, \mathrm{CH}_{2} \mathrm{CH}_{2} \mathrm{CH}_{2} \mathrm{CO}_{2} \mathrm{H}\right) .{ }^{13} \mathrm{C}$ NMR $(101$ $\left.\mathrm{MHz}, \mathrm{CDCl}_{3}\right) \delta 180.3,147.4,140.8,128.5,127.6,126.2,113.2,34.5,33.4,23.1$. NMR data correspond to the reported values. ${ }^{[19]}$

\section{3,3-Dimethyl-5-phenylhex-5-enoic acid (1p)}<smiles>C=C(CC(C)(C)CC(=O)O)c1ccccc1</smiles>

According to the general procedure, starting from 3,3-dimethyl-5-oxo-5-phenylpentanoic acid 20 $(1.70 \mathrm{~g}, 7.72 \mathrm{mmol}, \quad 1.0$ equiv. $)$ tBuOK $(2.25 \mathrm{~g}, 20.1 \mathrm{mmol}, 2.6$ equiv.) and bromo(methyl)triphenylphosphorane ( $3.58 \mathrm{~g}, 10.0 \mathrm{mmol}, 1.3$ equiv.), the product was obtained as a white solid $(0.35 \mathrm{~g}, 1.6 \mathrm{mmol}, 21 \%$ yield $) .{ }^{1} \mathbf{H} \mathbf{~ N M R}\left(400 \mathrm{MHz}, \mathrm{CDCl}_{3}\right) \delta 7.38-7.33(\mathrm{~m}, 2 \mathrm{H}$, $\mathrm{ArH}), 7.30-7.26(\mathrm{~m}, 2 \mathrm{H}, \mathrm{ArH}), 7.25-7.20(\mathrm{~m}, 1 \mathrm{H}, \mathrm{ArH}), 5.29\left(\mathrm{~d}, J=2.0 \mathrm{~Hz}, 1 \mathrm{H}, \mathrm{C}=\mathrm{CH}_{2}\right)$, $5.09\left(\mathrm{~d}, J=1.9 \mathrm{~Hz}, 1 \mathrm{H}, \mathrm{C}=\mathrm{CH}_{2}\right), 2.65\left(\mathrm{~s}, 2 \mathrm{H}, \mathrm{CH}_{2} \mathrm{CO}_{2} \mathrm{H}\right), 2.18\left(\mathrm{~s}, 2 \mathrm{H}, \mathrm{H}_{2} \mathrm{C}=\mathrm{CCH}_{2}\right), 0.92(\mathrm{~s}, 6 \mathrm{H}$, $\left.\mathrm{Me}_{2}\right) .{ }^{13} \mathrm{C}$ NMR $\left(101 \mathrm{MHz}, \mathrm{CDCl}_{3}\right) \delta 179.3,146.6,143.3,128.3,127.3,126.6,117.6,46.9,45.9$, 34.2, 27.8. NMR data correspond to the reported values. ${ }^{[19]}$

\section{2-((2-Phenylallyl)oxy)acetic acid (1q)}

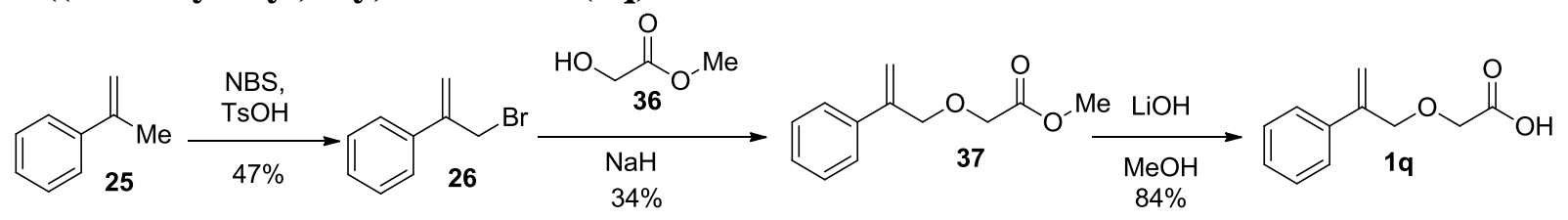

In an oven dried flask, prop-1-en-2-ylbenzene 25 (2.00 mL, $15.4 \mathrm{mmol}, 1.0$ equiv.) was diluted in dry THF (5 mL) and NBS (2.88 g, $16.2 \mathrm{mmol}, 1.05$ equiv.) and 4-methylbenzenesulfonic acid ( $2.65 \mathrm{~g}, 15.4 \mathrm{mmol}, 1.0$ equiv.) were added and the solution was refluxed at $100{ }^{\circ} \mathrm{C}$ for $4 \mathrm{~h}$. The reaction mixture was cooled to $\mathrm{rt}$ and then diluted with Pentane/Et2O (1/1: $20 \mathrm{~mL})$, washed with $\mathrm{H}_{2} \mathrm{O}$. The organic layer was dried over $\mathrm{MgSO}_{4}$ and concentrated under reduced pressure to obtain a yellow oil. Purification by column chromatography over silica gel using Pentane $(\mathrm{Rf}=0.95)$ as eluent afforded (3-bromoprop-1-en-2-yl)benzene $\mathbf{2 6}$ (1.43 g, $7.26 \mathrm{mmol}, 47 \%$ yield). ${ }^{\mathbf{1}} \mathbf{H}$ NMR $\left(400 \mathrm{MHz} \mathrm{CDCl}_{3}\right) \delta 7.53-7.47(\mathrm{~m}, 2 \mathrm{H}, \mathrm{ArH}), 7.42-7.30(\mathrm{~m}, 3 \mathrm{H}, \mathrm{ArH}), 5.56\left(\mathrm{~s}, 1 \mathrm{H}, \mathrm{C}=\mathrm{CH}_{2}\right)$, $5.50\left(\mathrm{~s}, 1 \mathrm{H}, \mathrm{C}=\mathrm{CH}_{2}\right), 4.39\left(\mathrm{~s}, 2 \mathrm{H}, \mathrm{CH}_{2}\right)$. NMR data correspond to the reported values. ${ }^{[14]}$ To the suspension of sodium hydride (104 mg, $2.60 \mathrm{mmol}, 1.3$ equiv.) in dry THF (4 mL) was added methyl 2-hydroxyacetate $36\left(200 \mu \mathrm{l}, 2.60 \mathrm{mmol}, 1.3\right.$ equiv.) at $0{ }^{\circ} \mathrm{C}$ under nitrogen. The resulting mixture was stirred for $30 \mathrm{~min}$ at the same temperature. (3-bromoprop-1-en-2-yl)benzene 27 (394 $\mathrm{mg}, 2.00 \mathrm{mmol}, 1.0$ equiv.) was then added to the reaction mixture. The mixture was allowed to warm to $\mathrm{rt}$ and stirred for $10 \mathrm{~h}$. The reaction was quenched with saturated $\mathrm{NH}_{4} \mathrm{Cl}$ aqueous solution. The organic layer was extracted with AcOEt twice $(2 \times 10 \mathrm{~mL})$, washed with brine, dried over with $\mathrm{Na}_{2} \mathrm{SO}_{4}$ and concentrated in vacuo. The residue was purified by $\mathrm{SiO}_{2}$ column chromatography (Pentane/AcOEt : 2/1) to give methyl 2-((2-phenylallyl)oxy)acetate $370.14 \mathrm{~g}$, $0.68 \mathrm{mmol}, 34 \%$ yield). ${ }^{1} \mathbf{H}$ NMR $\left(400 \mathrm{MHz}, \mathrm{CDCl}_{3}\right) \delta 7.51(\mathrm{~d}, J=7.4 \mathrm{~Hz}, 2 \mathrm{H}, \mathrm{ArH}), 7.35(\mathrm{t}, J$ $=7.3 \mathrm{~Hz}, 2 \mathrm{H}, \mathrm{ArH}), 7.32-7.28(\mathrm{~m}, 1 \mathrm{H}, \mathrm{ArH}), 5.59\left(\mathrm{~s}, 1 \mathrm{H}, \mathrm{C}=\mathrm{CH}_{2}\right), 5.36\left(\mathrm{~s}, 1 \mathrm{H}, \mathrm{C}=\mathrm{CH}_{2}\right), 4.52$ 
(s, $\left.2 \mathrm{H}, \mathrm{OCH}_{2} \mathrm{CO}_{2} \mathrm{Me}\right), 4.13\left(\mathrm{~s}, 2 \mathrm{H}, \mathrm{OCH}_{2}\right), 3.76$ (s, 3H, $\mathrm{CO}_{2} \mathrm{Me}$ ). NMR data correspond to the reported values. ${ }^{[20]}$ A mixture of methyl 2-((2-phenylallyl)oxy)acetate 37 (140 mg, $0.679 \mathrm{mmol}$, 1.0 equiv.) and lithium hydroxide $(81.0 \mathrm{mg}, 3.39 \mathrm{mmol}, 5.0$ equiv.) in $\mathrm{MeOH}(7 \mathrm{~mL})$ was stirred for $1 \mathrm{~h}$ at $50{ }^{\circ} \mathrm{C}$. The reaction mixture was cooled to $\mathrm{rt}$ and acidified with $10 \% \mathrm{HCl}$ aqueous solution. The product was then extracted with DCM $(3 \times 10 \mathrm{~mL})$ and dried over with $\mathrm{MgSO}_{4}$ and concentrated in vacuo. The residue was purified by $\mathrm{SiO}_{2}$ column chromatography (Pentane/AcOEt : 1/1) to give 2-((2-phenylallyl)oxy)acetic acid 1q (110 mg, $0.572 \mathrm{mmol}, 84 \%$ yield) as yellow oil. ${ }^{1} \mathbf{H}$ NMR $\left(400 \mathrm{MHz} \mathrm{CDCl}_{3}\right) \delta 7.48(\mathrm{dd}, J=8.2,1.8 \mathrm{~Hz}, 2 \mathrm{H}, \mathrm{ArH}), 7.41-$ $7.29(\mathrm{~m}, 3 \mathrm{H}, \mathrm{ArH}), 5.60\left(\mathrm{~s}, 1 \mathrm{H}, \mathrm{C}=\mathrm{CH}_{2}\right), 5.36\left(\mathrm{~s}, 1 \mathrm{H}, \mathrm{C}=\mathrm{CH}_{2}\right), 4.54\left(\mathrm{~s}, 2 \mathrm{H}, \mathrm{OCH}_{2} \mathrm{CO}_{2} \mathrm{Me}\right), 4.15$ $\left(\mathrm{s}, 2 \mathrm{H}, \mathrm{OCH}_{2}\right) .{ }^{13} \mathrm{C}$ NMR $\left(101 \mathrm{MHz}, \mathrm{CDCl}_{3}\right) \delta 175.4,143.1,138.1,128.6,128.2,126.2,115.9$, 73.5, 66.5. NMR data correspond to the reported values. ${ }^{[20]}$

\section{4-Benzylpent-4-enoic acid (1r)}

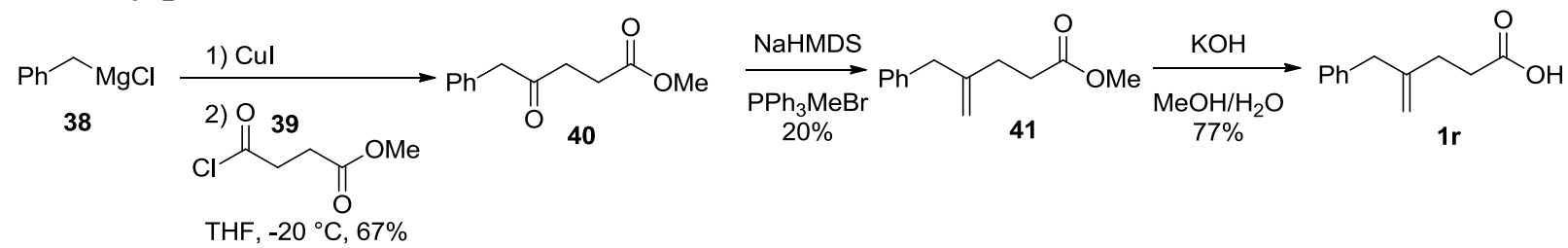

To a suspension of copper iodide $(2.00 \mathrm{~g}, 10.5 \mathrm{mmol}, 1.2$ equiv.) in dry THF (17 mL) was added a solution of benzylmagnesium chloride 38 (2M in THF) $(5.25 \mathrm{~mL}, 10.5 \mathrm{mmol}, 1.2$ equiv.) was added dropwise between $0{ }^{\circ} \mathrm{C}$ and $-20{ }^{\circ} \mathrm{C}$. The mixture was stirred between $0{ }^{\circ} \mathrm{C}$ and $-20{ }^{\circ} \mathrm{C}$ for $0.5 \mathrm{~h}$. After cooled at $-78{ }^{\circ} \mathrm{C}$, a solution of methyl 4-chloro-4-oxobutanoate $39(1.00 \mathrm{~mL}, 8.12$ mmol, 1.0 equiv.) in THF (10 mL) was added and the reaction was stirred at $-78{ }^{\circ} \mathrm{C}$ for $2 \mathrm{~h}$ and at room temperature for $30 \mathrm{~min}$. $\mathrm{NH}_{4} \mathrm{Cl}$ aq. solution was added to quench the reaction. EtOAc (30 $\mathrm{mL})$ was added and the organic layer was extracted twice with EtOAc ( $2 \mathrm{x} 20 \mathrm{~mL})$. The combined organic layers were washed with water, dried over $\mathrm{MgSO}_{4}$ and concentrated. The crude product was purified by flash $\mathrm{SiO}_{2}$ column (Pentane/EtOAc : 95/5 to 9/1) to give methyl 4-oxo-5phenylpentanoate 40 (1.20 g, $5.82 \mathrm{mmol}, 67 \%$ yield). ${ }^{1} \mathbf{H}$ NMR $\left(400 \mathrm{MHz}, \mathrm{CDCl}_{3}\right) \delta 7.37-7.30$ $(\mathrm{m}, 2 \mathrm{H}, \mathrm{ArH}), 7.30-7.16(\mathrm{~m}, 3 \mathrm{H}, \mathrm{ArH}), 3.74\left(\mathrm{~s}, 2 \mathrm{H}, \mathrm{CH}_{2} \mathrm{Ar}\right), 3.65(\mathrm{~s}, 3 \mathrm{H}, M e), 2.76(\mathrm{t}, \mathrm{J}=6.6$ $\left.\mathrm{Hz}, 2 \mathrm{H}, \mathrm{CH}_{2} \mathrm{CH}_{2} \mathrm{COOMe}\right), 2.56\left(\mathrm{t}, \mathrm{J}=6.6 \mathrm{~Hz}, 2 \mathrm{H}, \mathrm{CH}_{2} \mathrm{CH}_{2} \mathrm{COOMe}\right) .{ }^{13} \mathrm{C}$ NMR $(101 \mathrm{MHz}$, $\left.\mathrm{CDCl}_{3}\right) \delta 206.4,173.1,134.0,129.4,128.7,127.0,51.7,50.0,36.4,27.7$. NMR data correspond to the reported values. ${ }^{[21]}$ Under nitrogen, to a suspension of bromo(methyl)triphenylphosphorane (1.82 g, $5.09 \mathrm{mmol}, 1.5$ equiv.) in dry THF ( $8 \mathrm{~mL})$ was added dropwise a solution of sodium bis(trimethylsilyl)amide (2M in THF) $\left(2.04 \mathrm{~mL}, 4.07 \mathrm{mmol}, 1.2\right.$ equiv.) at $0{ }^{\circ} \mathrm{C}$. The mixture was stirred at $0{ }^{\circ} \mathrm{C}$ for $0.5 \mathrm{~h}$. Than a solution of methyl 4-oxo-5-phenylpentanoate $40(0.700 \mathrm{~g}, 3.39$ mmol, 1.0 equiv.) in dry THF $(8 \mathrm{~mL})$ was added at $0{ }^{\circ} \mathrm{C}$. The reaction was stirred at room temperature overnight. Solvent was removed in vacuo and the residue diluted with dichloromethane. The organic layer was washed with an aqueous $0.5 \mathrm{M} \mathrm{NaOH}$ solution, aqueous $\mathrm{NH}_{4} \mathrm{Cl}$ solution, brine, dried over $\mathrm{MgSO}_{4}$ and concentrated in vacuo. The crude product was purified by flash $\mathrm{SiO}_{2}$ column (Pentane/EtOAc : 95/5 to 9/1) to give methyl 4-benzylpent-4enoate $41(0.140 \mathrm{~g}, 0.685 \mathrm{mmol}, 20 \%$ yield $)$ as a colorless liquid. ${ }^{1} \mathbf{H}$ NMR $\left(400 \mathrm{MHz}, \mathrm{CDCl}_{3}\right) \delta$ $7.32-7.27(\mathrm{~m}, 2 \mathrm{H}, \mathrm{ArH}), 7.24-7.15(\mathrm{~m}, 3 \mathrm{H}, \mathrm{ArH}), 4.83\left(\mathrm{~m}, 1 \mathrm{H}, \mathrm{C}=\mathrm{CH}_{2}\right), 4.81(\mathrm{~m}, 1 \mathrm{H}$, $\left.\mathrm{C}=\mathrm{CH}_{2}\right), 3.65(\mathrm{~s}, 3 \mathrm{H}, \mathrm{Me}), 3.36\left(\mathrm{~s}, 2 \mathrm{H}, \mathrm{CH}_{2} \mathrm{Ar}\right), 2.49-2.42\left(\mathrm{~m}, 2 \mathrm{H}, \mathrm{CH}_{2} \mathrm{CH}_{2} \mathrm{COOMe}\right), 2.34-$ $2.26\left(\mathrm{~m}, 2 \mathrm{H}, \mathrm{CH}_{2} \mathrm{CH}_{2} \mathrm{COOMe}\right) .{ }^{13} \mathrm{C}$ NMR $\left(101 \mathrm{MHz}, \mathrm{CDCl}_{3}\right) \delta 173.7,147.3,139.4,129.1$, 128.5, 126.3, 111.7, 51.7, 43.4, 32.5, 30.4. IR 3085 (w), 3063 (w), 3028 (w), 2987 (w), 2980 (w), $2953(w), 2911(w), 2910(w), 2904(w), 2903(w), 2871(w), 2871(w), 2870(w), 2870(w)$, 
$2853(\mathrm{w}), 2844(\mathrm{w}), 2843(\mathrm{w}), 2362(\mathrm{w}), 2342(\mathrm{w}), 2333(\mathrm{w}), 1741(\mathrm{~s}), 1649(\mathrm{w}), 1456(\mathrm{w}), 1438$ (m), 1199 (w), 1198 (w), 1170 (w), 1042 (w), 912 (s). HRMS (ESI) calcd for $\mathrm{C}_{13} \mathrm{H}_{16} \mathrm{NaO}_{2}+[\mathrm{M}+\mathrm{Na}]^{+}$227.1042; found 227.1047. To a solution of methyl 4-benzylpent-4enoate $41(0.140 \mathrm{~g}, 0.685 \mathrm{mmol}, 1.0$ equiv. $)$ in $\mathrm{MeOH}(1.5 \mathrm{~mL})$ was added a solution of potassium hydroxide $(0.173 \mathrm{~g}, 3.08 \mathrm{mmol}, 4.5$ equiv. $)$ in water $(0.5 \mathrm{~mL})$ at $0{ }^{\circ} \mathrm{C}$. After stirring for $2 \mathrm{~h}$ at ambient temperature, the reaction was quenched with concentrated aqueous $\mathrm{HCl}$. The mixture was extracted with AcOEt. The organic layers were dried over anhydrous $\mathrm{Na}_{2} \mathrm{SO}_{4}$, filtered and concentrated in vacuo. The residue was purified by flash $\mathrm{SiO}_{2}$ column (DCM/MeOH : 100 to $95 / 5)$ to give 4-benzylpent-4-enoic acid $1 \mathbf{r}(0.100 \mathrm{~g}, 0.526 \mathrm{mmol}, 77 \%$ yield $)$ as a white oil. ${ }^{1} \mathbf{H}$ NMR $\left(400 \mathrm{MHz}, \mathrm{CDCl}_{3}\right) \delta 7.32-7.25(\mathrm{~m}, 2 \mathrm{H}, \mathrm{ArH}), 7.25-7.14(\mathrm{~m}, 3 \mathrm{H}, \mathrm{ArH}), 4.85(\mathrm{~d}$, $\left.J=1.6 \mathrm{~Hz}, 1 \mathrm{H}, \mathrm{C}=\mathrm{CH}_{2}\right), 4.83\left(\mathrm{q}, J=1.2 \mathrm{~Hz}, 1 \mathrm{H}, \mathrm{C}=\mathrm{CH}_{2}\right), 3.37\left(\mathrm{~s}, 2 \mathrm{H}, \mathrm{ArCH}_{2}\right), 2.50(\mathrm{~m}, 2 \mathrm{H}$, $\left.\mathrm{CH}_{2} \mathrm{CH}_{2} \mathrm{CO}_{2} \mathrm{H}\right), 2.30\left(\mathrm{t}, J=7.7 \mathrm{~Hz}, 2 \mathrm{H}, \mathrm{CH}_{2} \mathrm{CH}_{2} \mathrm{CO}_{2} \mathrm{H}\right) .{ }^{13} \mathbf{C}$ NMR $\left(101 \mathrm{MHz}, \mathrm{CDCl}_{3}\right) \delta 179.8$, $147.0,139.3,129.1,128.5,126.4,111.9,43.4,32.5,30.0$. NMR data correspond to the reported values. ${ }^{[22]}$

\section{4-Methylene-7-phenylheptanoic acid (1s)}

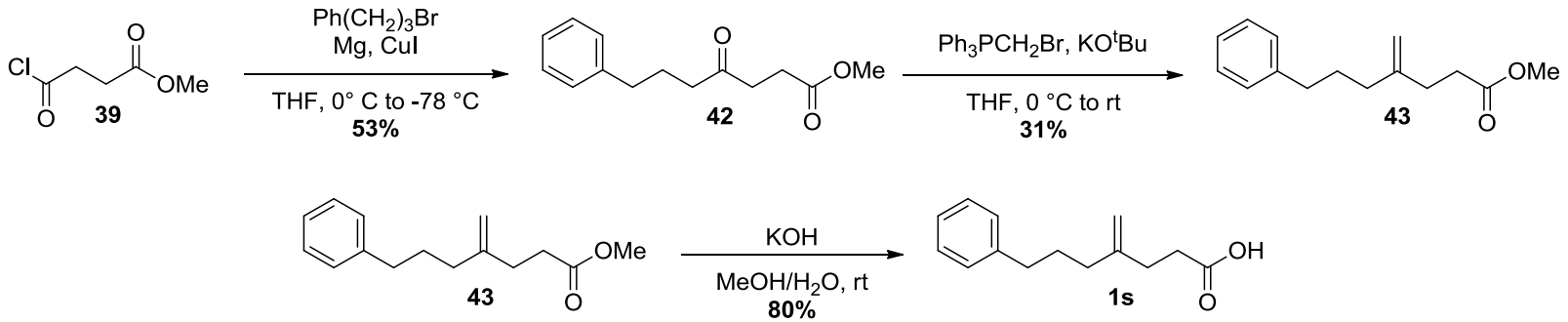

Mg turnings ( $0.440 \mathrm{~g}, 18.0 \mathrm{mmol}, 2.8$ equiv.) and a crystal of iodine were suspended in THF (9.0 $\mathrm{mL}$ ). (3-Bromopropyl)benzene $(1.76 \mathrm{~mL}, 11.6 \mathrm{mmol}, 1.8$ equiv.) was then added dropwise leading to the start of the reaction. In a two-necked round-bottomed flask, $\mathrm{CuI}(2.22 \mathrm{~g}, 11.7$ mmol, 1.8 equiv.) was suspended in THF $(18 \mathrm{~mL})$ and the resulting grey mixture was cooled down to $0{ }^{\circ} \mathrm{C}$. The freshly prepared Grignard reagent was then slowly added, which was stirred at $0{ }^{\circ} \mathrm{C}$ for $30 \mathrm{~min}$. The mixture was then cooled to $-78{ }^{\circ} \mathrm{C}$ and a solution of methyl succinyl chloride 39 (2.4 mL, $18 \mathrm{mmol}, 1.0$ equiv.) in THF $(9.0 \mathrm{~mL})$ was added dropwise. After stirring at $-78{ }^{\circ} \mathrm{C}$ for $5 \mathrm{~min}$, the mixture was warmed back to $0{ }^{\circ} \mathrm{C}$ and stirring was continued at this temperature for addition $60 \mathrm{~min}$. The reaction was quenched by addition of water $(20 \mathrm{~mL})$, followed by aq. $\mathrm{HCl}(1.0 \mathrm{M} ; 20 \mathrm{~mL})$, still at $0{ }^{\circ} \mathrm{C}$. Diethyl ether was added. The aqueous layer was then separated and extracted with diethyl ether $(2 \times 20 \mathrm{~mL})$. The combined organic layers were washed twice with sat. aq. $\mathrm{NaHCO}_{3}$, once with brine, dried over $\mathrm{MgSO}_{4}$, filtered and concentrated in vacuo to give a yellow crude oil. The latter was submitted to column chromatography $\left(\mathrm{SiO}_{2}\right.$, Pentane/EtOAc $24 / 1$ to 10/1) to afford pure methyl 4-oxo-7phenylheptanoate $\mathbf{4 2}(0.805 \mathrm{~g}, 3.44 \mathrm{mmol}, 53 \%$ yield $)$ as a pale yellow oil. ${ }^{1} \mathbf{H}$ NMR (400 MHz, $\left.\mathrm{CDCl}_{3}\right) \delta 7.33-7.25(\mathrm{~m}, 2 \mathrm{H}, \mathrm{ArH}), 7.23-7.14(\mathrm{~m}, 3 \mathrm{H}, \mathrm{ArH}), 3.68\left(\mathrm{~s}, 3 \mathrm{H}, \mathrm{OCH}_{3}\right), 2.70(\mathrm{t}, J=6.2$ $\mathrm{Hz}, 2 \mathrm{H}, \mathrm{COCH}_{2} \mathrm{CH}_{2} \mathrm{CO}_{2} \mathrm{Me}$ ), $2.63\left(\mathrm{t}, J=7.5 \mathrm{~Hz}, 2 \mathrm{H}, \mathrm{COCH}_{2} \mathrm{CH}_{2} \mathrm{CH}_{2} \mathrm{Ph}\right), 2.58(\mathrm{t}, J=6.2 \mathrm{~Hz}$, $2 \mathrm{H}, \mathrm{COCH}_{2} \mathrm{CH}_{2} \mathrm{CO}_{2} \mathrm{Me}$ ), 2.47 (t, $J=7.4 \mathrm{~Hz}, 2 \mathrm{H}, \mathrm{COCH}_{2} \mathrm{CH}_{2} \mathrm{CH}_{2} \mathrm{Ph}$ ), 1.94 (pent, $J=7.4 \mathrm{~Hz}, 2 \mathrm{H}$, $\mathrm{COCH}_{2} \mathrm{CH}_{2} \mathrm{CH}_{2} \mathrm{Ph}$ ). NMR data correspond to the reported values. ${ }^{[23]}$ Following a standard procedure, $t \mathrm{BuOK}(0.771 \mathrm{~g}, 6.87 \mathrm{mmol}, 2.0$ equiv.) was suspended in THF $(17 \mathrm{~mL})$. The suspension was cooled to $0{ }^{\circ} \mathrm{C}$ and methyltriphenylphosphonium bromide $(2.58 \mathrm{~g}, 7.22 \mathrm{mmol}$, 2.1 equiv.) was added, leading to the formation of a bright yellow suspension. The latter was 
stirred at $0{ }^{\circ} \mathrm{C}$ for 30 minutes. A solution of methyl 4-oxo-7-phenylheptanoate 42 (0.805 g, 3.44 mmol, 1.0 equiv.) in THF (1 mL) was then added at the same temperature. The reaction mixture was allowed to warm to room temperature and stirred overnight. The reaction was quenched by addition of sat. aq. $\mathrm{NH}_{4} \mathrm{Cl}$ at $0{ }^{\circ} \mathrm{C}$. The aqueous layer was extracted with ether $(3 \mathrm{x} 15 \mathrm{~mL})$ and the combined organic extracts were washed with brine, dried over $\mathrm{MgSO}_{4}$, filtered and concentrated in vacuo to give a yellow crude solid. The latter was submitted to column chromatography $\left(\mathrm{SiO}_{2}\right.$, pentane/EtOAc $24.5 / 0.5$ to $\left.24 / 1\right)$ to afford methyl 4-methylene-7phenylheptanoate $43(0.245 \mathrm{~g}, 1.06 \mathrm{mmol}, 31 \%$ yield $)$ as a pale yellow oil. ${ }^{\mathbf{1}} \mathbf{H}$ NMR (400 MHz, $\left.\mathrm{CDCl}_{3}\right) \delta 7.32-7.23(\mathrm{~m}, 2 \mathrm{H}, \mathrm{ArH}), 7.22-7.14(\mathrm{~m}, 3 \mathrm{H}), 4.78\left(\mathrm{~s}, 1 \mathrm{H}, \mathrm{C}=\mathrm{CH}_{2}\right), 4.75(\mathrm{~s}, 1 \mathrm{H}$, $\left.\mathrm{C}=\mathrm{CH}_{2}\right), 3.67\left(\mathrm{~s}, 3 \mathrm{H}, \mathrm{OCH}_{3}\right), 2.61\left(\mathrm{t}, J=7.3 \mathrm{~Hz}, 2 \mathrm{H}\right.$, aliphatic $\left.\mathrm{CH}_{2}\right), 2.47\left(\mathrm{~m}, 2 \mathrm{H}\right.$, aliphatic $\left.\mathrm{CH}_{2}\right)$, $2.34\left(\mathrm{t}, J=7.9 \mathrm{~Hz}, 2 \mathrm{H}\right.$, aliphatic $\left.\mathrm{CH}_{2}\right), 2.07\left(\mathrm{t}, J=7.7 \mathrm{~Hz}, 2 \mathrm{H}\right.$, aliphatic $\left.\mathrm{CH}_{2}\right), 1.77$ (p, $J=7.7$, $\mathrm{Hz}, 2 \mathrm{H}$, aliphatic $\mathrm{CH}_{2}$ ). Following a standard procedure, methyl 4-methylene-6-phenylheptanoate 43 (0.245 g, $0.105 \mathrm{mmol}, 1.0$ equiv.) was dissolved in $\mathrm{MeOH}(2.2 \mathrm{~mL})$. The solution was cooled to $0{ }^{\circ} \mathrm{C}$ and a solution of $\mathrm{KOH}(0.30 \mathrm{~g}, 5.3 \mathrm{mmol}, 5.0$ equiv. $)$ in water $(0.4 \mathrm{~mL})$ was slowly added. The cooling bath was removed and stirring was continued at room temperature for $2 \mathrm{~h}$. During this time, the initial suspension converted into a pale yellow clear solution. The mixture was then diluted with aq. $\mathrm{NaOH}(1.0 \mathrm{M})$ and extracted with ether $(3 \times 10 \mathrm{~mL})$. It was then acidified with concentrated aq. $\mathrm{HCl}$ until $\mathrm{pH}<3$ and extracted with DCM (3 x $10 \mathrm{~mL})$. The combined organic extracts were washed with brine, dried $\mathrm{MgSO}_{4}$, and concentrated in vacuo to provide pure 4-methylene-7-phenylheptanoic acid $1 \mathrm{~s}(0.185 \mathrm{~g}, 0.847 \mathrm{mmol}, 80 \%$ yield $)$ as a colorless viscous oil. ${ }^{1} \mathbf{H}$ NMR $\left(400 \mathrm{MHz},\left(\mathrm{CD}_{3}\right)_{2} \mathrm{CO}\right) \delta 10.53(\mathrm{~s}, 1 \mathrm{H}, \mathrm{COOH}), 7.30-7.19$ (m, $4 \mathrm{H}, \mathrm{ArH}), 7.19-7.13(\mathrm{~m}, 1 \mathrm{H}, \mathrm{ArH}), 4.78\left(\mathrm{dd}, J=2.4,1.3 \mathrm{~Hz}, 2 \mathrm{H}, \mathrm{C}=\mathrm{CH}_{2}\right), 2.67-2.57(\mathrm{~m}, 2 \mathrm{H}$, aliphatic $\left.\mathrm{CH}_{2}\right), 2.47-2.41\left(\mathrm{~m}, 2 \mathrm{H}\right.$, aliphatic $\left.\mathrm{CH}_{2}\right), 2.38-2.29\left(\mathrm{~m}, 2 \mathrm{H}\right.$, aliphatic $\left.\mathrm{CH}_{2}\right), 2.11(\mathrm{t}, J$ $=7.7 \mathrm{~Hz}, 2 \mathrm{H}$, aliphatic $\left.\mathrm{CH}_{2}\right), 1.83-1.70\left(\mathrm{~m}, 2 \mathrm{H}\right.$, aliphatic $\left.\mathrm{CH}_{2}\right) \cdot{ }^{13} \mathbf{C} \mathbf{N M R}(100 \mathrm{MHz}$, $\left.\left(\mathrm{CD}_{3}\right)_{2} \mathrm{CO}\right) \delta 174.3,149.2,143.4,129.3,129.2,126.6,109.9,36.6,36.7,32.8,31.6,30.5$. IR 3074 (m), 3028 (m), 2932 (m), 2864 (m), 2672 (w), 1948 (w), 1708 (s), 1650 (w), 1607 (w), 1493 (w), 1444 (m), 1295 (m), 1217 (w), 1165 (w), 1075 (w), 1026 (w), 936 (w), 896 (m). HRMS (ESI) calcd for $\mathrm{C}_{14} \mathrm{H}_{17} \mathrm{O}_{2}^{-}[\mathrm{M}+\mathrm{H}-1]^{-} 217.1234$; found 217.1231 .

\section{2-Allylbenzoic acid (1t)}

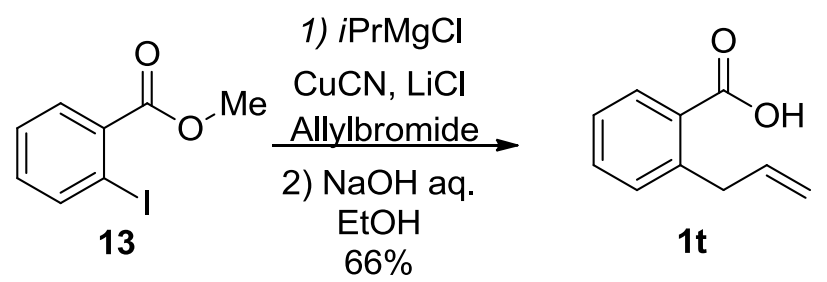

Under nitrogen, a solution of isopropylmagnesium chloride ( $2 \mathrm{M}$ in THF, $5.25 \mathrm{~mL}, 10.5 \mathrm{mmol}$, 1.5 equiv.) was added dropwise to a solution of methyl 2-iodobenzoate $13(1 \mathrm{~mL}, 7 \mathrm{mmol}, 1.0$ equiv.) in dry $\mathrm{THF}(75 \mathrm{~mL})$ at $-40{ }^{\circ} \mathrm{C}$. The resulting mixture was stirred at $-40{ }^{\circ} \mathrm{C}$ for $1.5 \mathrm{~h}$. Then it was added via cannula to a freshly prepared solution of cyanocopper $(627 \mathrm{mg}, 7.00 \mathrm{mmol}, 1.0$ equiv.) and lithium chloride (594 mg, $14.0 \mathrm{mmol}, 2.0$ equiv.) in dry THF (20 mL), followed by dropwise addition of 3-bromoprop-1-ene $(2.42 \mathrm{~mL}, 28.0 \mathrm{mmol}, 4.0$ equiv.). After being stirred at $-40{ }^{\circ} \mathrm{C}$ for $4 \mathrm{~h}$, the mixture was allowed to warm to room temperature, diluted with EtOAc (50 $\mathrm{mL}$ ) and filtered over Celite. The organic solution was washed with a $25 \%$ ammonia aqueous 
solution. The aqueous layer was extracted with EtOAc $(3 \times 30 \mathrm{~mL})$. The combined organic layers were washed with brine, dried over $\mathrm{MgSO}_{4}$, filtered and concentrated in vacuo. The crude product was filtered through a short pad of silica eluting with Pentane/EtOAc $=20 / 1$, and then dissolved in $\mathrm{EtOH}(50 \mathrm{~mL})$. A $2 \mathrm{M} \mathrm{NaOH}$ solution $(50 \mathrm{~mL})$ was added and the resulting mixture was stirred at room temperature for $4 \mathrm{~h}$. $\mathrm{EtOH}$ was then removed under reduced pressure and the aqueous layer was washed with $\mathrm{Et}_{2} \mathrm{O}(3 \times 20 \mathrm{~mL})$. The aqueous solution was acidified to $\mathrm{pH} 3$ with $2 \mathrm{M} \mathrm{HCl}$ solution and extracted with $\mathrm{Et}_{2} \mathrm{O}(3 \times 50 \mathrm{~mL})$. The combined organic layers were dried over $\mathrm{MgSO}_{4}$, filtered and concentrated in vacuo. The residue was purified by flash $\mathrm{SiO}_{2}$ column (DCM/MeOH : 100 to 95/5) to afford 2-allylbenzoic acid 1t (750 mg, $4.62 \mathrm{mmol}, 66 \%$ yield) $(\mathrm{Rf}=0.4 \mathrm{DCM} / \mathrm{MeOH}: 95 / 5)$ as a white solid. ${ }^{1} \mathbf{H} \mathbf{~ N M R}\left(400 \mathrm{MHz}, \mathrm{CDCl}_{3}\right) \delta 12.49$ (bs, $\left.1 \mathrm{H}, \mathrm{CO}_{2} H\right), 8.09(\mathrm{dd}, J=8.1,1.5 \mathrm{~Hz}, 1 \mathrm{H}, \mathrm{ArH}), 7.52(\mathrm{td}, J=7.5,1.5 \mathrm{~Hz}, 1 \mathrm{H}, \mathrm{ArH}), 7.39-7.29$ $(\mathrm{m}, 2 \mathrm{H}, \mathrm{ArH}), 6.17-5.95\left(\mathrm{~m}, 1 \mathrm{H}, \mathrm{CH}=\mathrm{CH}_{2}\right), 5.09\left(\mathrm{t}, J=1.5 \mathrm{~Hz}, 1 \mathrm{H}, \mathrm{C}=C_{2} H_{2}\right), 5.06(\mathrm{dq}, J=7.6$, $\left.1.6 \mathrm{~Hz}, 1 \mathrm{H}, \mathrm{C}=\mathrm{CH}_{2}\right), 3.87(\mathrm{dt}, J=6.4,1.5 \mathrm{~Hz}, 2 \mathrm{H}) .{ }^{13} \mathrm{C} \mathrm{NMR}\left(101 \mathrm{MHz}, \mathrm{CDCl}_{3}\right) \delta 173.6,142.9$, $137.6,133.3,131.7,131.3,128.4,126.5,115.7,38.5$. NMR data correspond to the reported values. $^{[24]}$

\section{2-(2-Methylallyl)benzoic acid (1u)}
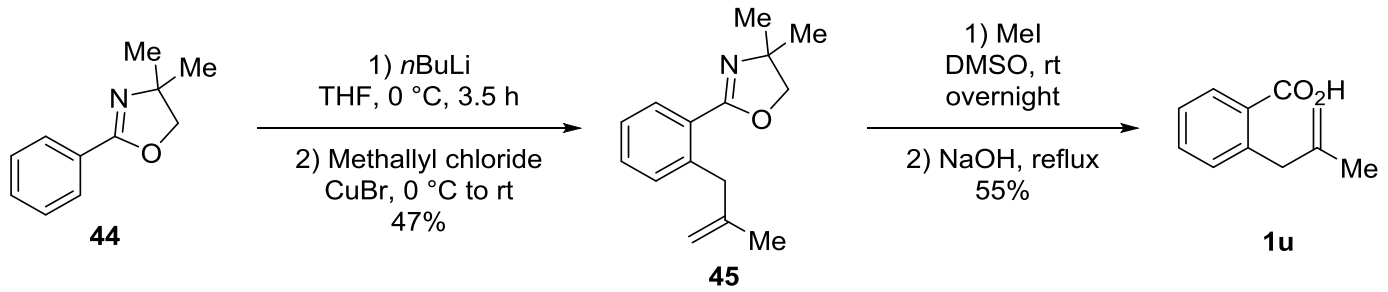

Under nitrogen, $n \mathrm{BuLi}(2.5 \mathrm{M}$ in hexanes, $6.1 \mathrm{~mL}, 15 \mathrm{mmol}, 1.3$ equiv) was added dropwise to a solution of 4,4-dimethyl-2-phenyl-2-oxazoline 44 (2.0 g, $11 \mathrm{mmol}, 1.0$ equiv) in dry THF (34 $\mathrm{mL}$, previously flushed with argon) at $0{ }^{\circ} \mathrm{C}$. The mixture was stirred at $0{ }^{\circ} \mathrm{C}$ for $3 \mathrm{~h} 30$ and then it was transferred to a suspension of $\mathrm{CuBr}(1.61 \mathrm{~g}, 11.2 \mathrm{mmol}, 0.99$ equiv) in dry THF $(10 \mathrm{~mL})$ via cannula. The resulting green mixture was stirred at $0{ }^{\circ} \mathrm{C}$ for $1 \mathrm{~h} 30$, methallyl chloride $(1.0 \mathrm{~mL}, 10$ mmol, 0.9 equiv) was added and the reaction mixture was stirred at $\mathrm{rt}$ overnight. The reaction was then quenched by addition of water $(10 \mathrm{~mL})$ and aqueous $\mathrm{NH}_{3}(25 \% \mathrm{v} / \mathrm{v}$. solution, $10 \mathrm{~mL})$. The aqueous layer was extracted with $\mathrm{Et}_{2} \mathrm{O}(3 \times 20 \mathrm{~mL})$ and the combined organic layers were washed with brine, dried over $\mathrm{MgSO}_{4}$, filtered and concentrated under reduced pressure. Purification of the crude product by column chromatography $\left(\mathrm{SiO}_{2}\right.$, Hexane/EtOAc 10/1) afforded 4,4-dimethyl-2-(2-(2-methylallyl)phenyl)-4,5-oxazoline 45 (1.26 g, 5.49 mmol, $47 \%$ yield) as a dark oil. Oxazoline $\mathbf{4 5}$ was converted to the methiodide salt by stirring in excess MeI (2.1 mL, $33 \mathrm{mmol}, 6$ equiv) and DMSO $(1.2 \mathrm{~mL})$ overnight at $\mathrm{rt}$. The solvents were then evaporated in vacuo and the crude oxazoline methiodide was treated with aqueous $\mathrm{NaOH}(2.0 \mathrm{M}$; $17.3 \mathrm{~mL}$ ) at reflux for $9 \mathrm{~h}$. The solution was then allowed to cool to $\mathrm{rt}$ and washed with $\mathrm{CH}_{2} \mathrm{Cl}_{2}(3$ $\mathrm{x} 20 \mathrm{~mL}$ ). The aqueous layer was acidified to $\mathrm{pH} 1$ with concentrated $\mathrm{HCl}$ and extracted with $\mathrm{CH}_{2} \mathrm{Cl}_{2}(3 \times 25 \mathrm{~mL})$. The combined organic layers were washed with brine, dried over $\mathrm{MgSO}_{4}$, filtered and concentrated in vacuo. The crude product was filtered on $\mathrm{SiO}_{2}$ to afford 2-(2methylallyl)benzoic acid $1 \mathbf{u}(0.53 \mathrm{~g}, 3.1 \mathrm{mmol}, 55 \%$ yield $)$ as a colorless solid. $\mathrm{R}_{\mathrm{f}}$ 0.42 (28:12:1 hexane $\left./ \mathrm{Et}_{2} \mathrm{O} / \mathrm{HCO}_{2} \mathrm{H}\right) ;{ }^{1} \mathbf{H}$ NMR $\left(400 \mathrm{MHz}, \mathrm{CDCl}_{3}\right) \delta 11.2\left(\mathrm{bs}, 1 \mathrm{H}, \mathrm{CO}_{2} \mathrm{H}\right), 8.03$ (dd, J = 7.4, 0.9 $\mathrm{Hz}, 1 \mathrm{H}, \mathrm{ArH}), 7.49$ (td, $J=7.6,1.5 \mathrm{~Hz}, 1 \mathrm{H}, \mathrm{ArH}), 7.36-7.26(\mathrm{~m}, 2 \mathrm{H}, \mathrm{ArH}), 4.80(\mathrm{~d}, J=0.7 \mathrm{~Hz}$, $\left.1 \mathrm{H}, \mathrm{C}=\mathrm{CH}_{2}\right), 4.47\left(\mathrm{~d}, \mathrm{~J}=0.7 \mathrm{~Hz}, 1 \mathrm{H}, \mathrm{C}=\mathrm{CH}_{2}\right), 3.78\left(\mathrm{~s}, 2 \mathrm{H}, \mathrm{CH}_{2}\right), 1.76\left(\mathrm{~s}, 3 \mathrm{H}, \mathrm{CH}_{3}\right) ;{ }^{13} \mathbf{C ~ N M R}$ 
$\left(100 \mathrm{MHz}, \mathrm{CDCl}_{3}\right) \delta 173.1,145.4,142.2,132.7,131.6,131.5,128.8,126.3,111.6,41.8,23.0$. NMR data correspond to the reported values. ${ }^{[25]}$

\section{2-(2-((Benzyloxy)methyl)allyl)benzoic acid (1v)}
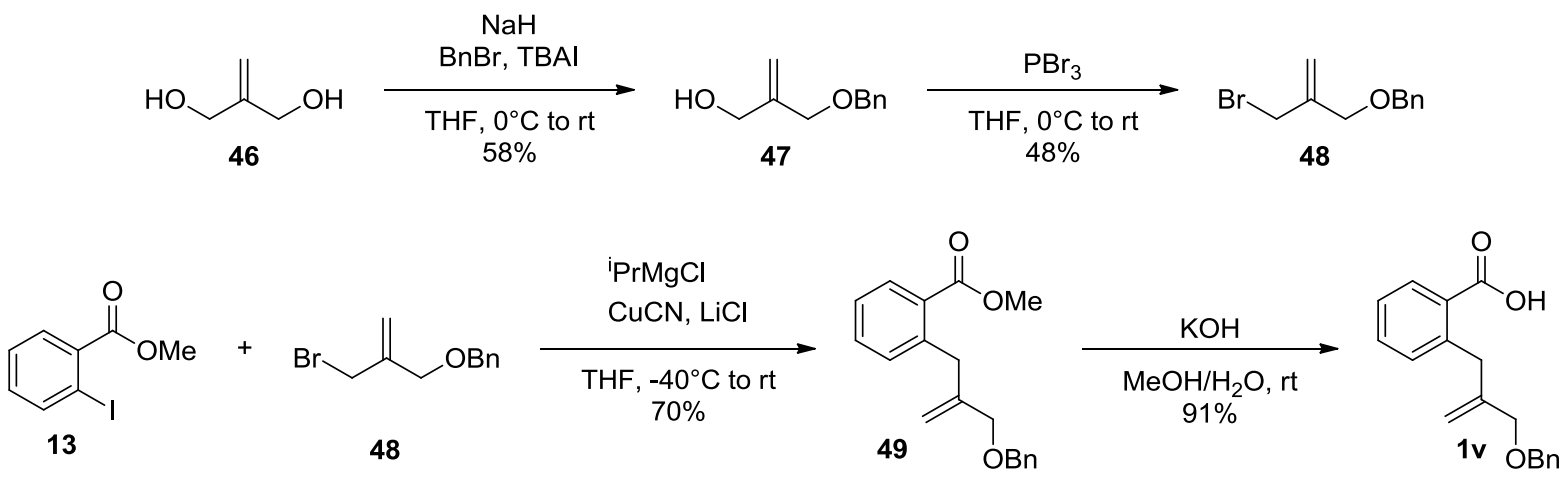

Following a standard procedure, 2-methylenepropane-1,3-diol $46(0.70 \mathrm{~mL}, 8.6 \mathrm{mmol}, 1.0$ equiv.) was dissolved in THF (dry; $26.8 \mathrm{~mL}$ ) and the resulting solution was cooled to $0{ }^{\circ} \mathrm{C}$. $\mathrm{NaH}$ ( $60 \%$ suspension in mineral oil; $0.343 \mathrm{~g}, 8.58 \mathrm{mmol}, 1.0$ equiv.) was then added, immediately resulting in vigorous gas release. The pale yellow mixture was stirred at $0{ }^{\circ} \mathrm{C}$ for 30 min and then at room temperature for $10 \mathrm{~min}$. TBAI $(0.158 \mathrm{~g}, 0.429 \mathrm{mmol}, 5 \mathrm{~mol} \mathrm{\%})$ was then added, immediately followed by benzyl bromide $(0.87 \mathrm{~mL}, 7.3 \mathrm{mmol}, 0.85$ equiv.). Stirring was then continued at room temperature for $4 \mathrm{~h}$. The reaction was therefore quenched by cautious addition of water, followed by sat. aq. $\mathrm{NH}_{4} \mathrm{Cl}$. The aqueous layer was then extracted with EtAOc $(3 \times 25$ $\mathrm{mL})$. The combined extracts were washed with water, brine, dried over $\mathrm{MgSO}_{4}$, filtered and concentrated in vacuo to afford a pale yellow crude oil. The latter was purified through column chromatography $\left(\mathrm{SiO}_{2}\right.$; pentane/EtAOc 4/1) to afford 2-((benzyloxy)methyl)prop-2-en-1-ol 47 (1.53 g, $5.02 \mathrm{mmol}, 58 \%$ yield) as a colorless oil. ${ }^{1} \mathbf{H}$ NMR $\left(400 \mathrm{MHz}, \mathrm{CDCl}_{3}\right) \delta 7.39-7.27(\mathrm{~m}$, $5 \mathrm{H}, \operatorname{ArH}), 5.21\left(\mathrm{~d}, J=1.6 \mathrm{~Hz}, 1 \mathrm{H}, \mathrm{C}=\mathrm{CH}_{2}\right), 5.16\left(\mathrm{~d}, J=1.2 \mathrm{~Hz}, 1 \mathrm{H}, \mathrm{C}=\mathrm{CH}_{2}\right), 4.53(\mathrm{~s}, 2 \mathrm{H}$, $\left.\mathrm{OCH}_{2} \mathrm{Ph}\right), 4.20\left(\mathrm{~m}, 2 \mathrm{H}, \mathrm{OCH}_{2} \mathrm{C}=\mathrm{C}\right), 4.10\left(\mathrm{~d}, J=1.1 \mathrm{~Hz}, 2 \mathrm{H}, \mathrm{OCH}_{2} \mathrm{C}=\mathrm{C}\right) . \mathrm{NMR}$ data correspond to the reported values. ${ }^{[26]}$ Following a reported procedure, ${ }^{[27]} 2-(($ benzyloxy)methyl)prop-2-en-1ol 47 (0.890 g, $4.99 \mathrm{mmol}, 1.0$ equiv.) was dissolved in dry $\mathrm{Et}_{2} \mathrm{O}(25 \mathrm{~mL})$. The resulting solution was cooled down to $0{ }^{\circ} \mathrm{C}$ (ice-water bath) and phosphorus tribromide $(0.56 \mathrm{~mL}, 6.0 \mathrm{mmol}, 1.2$ equiv.) was added dropwise. The reaction mixture was allowed to warm to room temperature and stirred for $3 \mathrm{~h}$. The reaction was quenched through cautious, dropwise addition of water (exothermy!!). The aqueous layer was then extracted with ether $(3 \times 25 \mathrm{~mL})$. The combined organic extracts were washed with brine, dried over $\mathrm{MgSO}_{4}$, filtered and concentrated in vacuo. The resulting crude oil was submitted to column chromatography $\left(\mathrm{SiO}_{2}\right.$; pentane/Et $\left.\mathrm{E}_{2} \mathrm{O} 80 / 20\right)$ to afford (((2-(bromomethyl)allyl)oxy)methyl)benzene $48(0.574 \mathrm{~g}, 2.38 \mathrm{mmol}, 48 \%$ yield $)$ as a pale yellow oil. ${ }^{1} \mathbf{H}$ NMR (400 MHz, $\left.\mathrm{CDCl}_{3}\right) \delta 7.40-7.33(\mathrm{~m}, 4 \mathrm{H}, \mathrm{ArH}), 7.31(\mathrm{~m}, 1 \mathrm{H}, \mathrm{ArH}), 5.36(\mathrm{~d}$, $\left.J=0.9 \mathrm{~Hz}, 1 \mathrm{H}, \mathrm{C}=\mathrm{CH}_{2}\right), 5.27\left(\mathrm{~d}, J=1.4 \mathrm{~Hz}, 1 \mathrm{H}, \mathrm{C}=\mathrm{CH}_{2}\right), 4.54\left(\mathrm{~s}, 2 \mathrm{H}, \mathrm{CH}_{2}\right), 4.16(\mathrm{~d}, J=1.2 \mathrm{~Hz}$, $\left.2 \mathrm{H}, \mathrm{CH}_{2}\right), 4.05\left(\mathrm{~d}, \mathrm{~J}=0.8 \mathrm{~Hz}, 2 \mathrm{H}, \mathrm{CH}_{2}\right)$. NMR data correspond to the reported values. ${ }^{[28]}$ Following a reported procedure, ${ }^{[10]}$ In a $25 \mathrm{~mL}$ two-necked round-bottomed flask, methyl 2iodobenzoate $13(0.23 \mathrm{~mL}, 1.5 \mathrm{mmol}, 1.0$ equiv.) was dissolved in dry THF (3.0 mL) and the solution was cooled to $-40{ }^{\circ} \mathrm{C}$ (acetonitrile/dry ice bath). isoPropyl magnesium chloride $(2.0 \mathrm{M}$ in THF; $1.0 \mathrm{~mL}, 2.0 \mathrm{mmol}, 1.35$ equiv.) was added dropwise, resulting in the formation of a bright yellow suspension, which was stirred at the same temperature for $1 \mathrm{~h}$. A freshly prepared solution of $\mathrm{CuCN}$ (0.133 g, $1.48 \mathrm{mmol}, 1.0$ equiv.) and $\mathrm{LiCl}(0.126 \mathrm{~g}, 2.97 \mathrm{mmol}, 2.0$ equiv.) in dry THF 
(3.0 $\mathrm{m}$ ) was then added dropwise and the resulting mixture was stirred at $-40{ }^{\circ} \mathrm{C}$ for additional 40 min. A solution of (((2-(bromomethyl)allyl)oxy)methyl)benzene $48(0.555 \mathrm{~g}, 2.30 \mathrm{mmol}, 1.55$ equiv.) in dry THF $(0.50 \mathrm{~mL})$ was finally added dropwise at $-40{ }^{\circ} \mathrm{C}$. The mixture converted at this point into a green-brownish suspension, which was stirred overnight while allowing it to warm to room temperature. The reaction was then quenched by pouring the mixture onto a mixture of ice and sat. aq. $\mathrm{NH}_{4} \mathrm{Cl}$. Upon separation from the organic layer, the aqueous layer was extracted with EtOAc $(3 \times 10 \mathrm{~mL})$. The combined organic extracts were washed with brine, dried over $\mathrm{MgSO}_{4}$, filtered and concentrated in vacuo to provide a pale yellow crude oil. The latter was then submitted to column chromatography $\left(\mathrm{SiO}_{2}\right.$; pentane/EtOAc 24/1 to 10/1) to afford methyl 2-(2-((benzyloxy)methyl)allyl)benzoate $\quad 49 \quad(0.440 \quad \mathrm{~g}, \quad 1.48 \quad \mathrm{mmol}, \quad 70 \%$ yield $) \quad \mathrm{R}_{\mathrm{f}} \quad 0.85$ (pentane/EtOAc 5/1) as a colorless oil. The latter $(0.245 \mathrm{~g}, 0.105 \mathrm{mmol}, 1.0$ equiv.) was dissolved in $\mathrm{MeOH}(2.2 \mathrm{~mL})$. The solution was cooled to $0{ }^{\circ} \mathrm{C}$ and a solution of $\mathrm{KOH}(0.30 \mathrm{~g}, 5.3$ mmol, 5.0 equiv. $)$ in water $(0.4 \mathrm{~mL})$ was slowly added. The cooling bath was removed and stirring was continued at room temperature for $2 \mathrm{~h}$. During this time, the initial suspension converted into a pale yellow clear solution. Most of $\mathrm{MeOH}$ was then removed under reduced pressure. The resulting aqueous mixture was diluted with aq. $\mathrm{NaOH}(1.0 \mathrm{M})$ and extracted with ether $(3 \times 10 \mathrm{~mL})$. It was then acidified with concentrated aq. $\mathrm{HCl}$ until $\mathrm{pH}<3$ and extracted with DCM $(3 \times 10 \mathrm{~mL})$. The combined organic extracts were washed with brine, dried $\mathrm{MgSO}_{4}$, concentrated in vacuo to provide pure 2-(2-((benzyloxy)methyl)allyl)benzoic acid $\mathbf{1 v}(0.267 \mathrm{~g}$, $0.946 \mathrm{mmol}, 91 \%$ yield) as a crystalline solid. ${ }^{1} \mathbf{H}$ NMR $\left(400 \mathrm{MHz}, \mathrm{CDCl}_{3}\right) \delta 12.03(\mathrm{br} \mathrm{s}, 1 \mathrm{H}$, $\left.\mathrm{CO}_{2} H\right), 8.03(\mathrm{dd}, J=7.8,1.6 \mathrm{~Hz}, 1 \mathrm{H}, \mathrm{Ar} H), 7.49(\mathrm{td}, J=7.5,1.5 \mathrm{~Hz}, 1 \mathrm{H}, \mathrm{Ar} H), 7.41-7.26(\mathrm{~m}$, $7 \mathrm{H}, \mathrm{ArH}), 5.12\left(\mathrm{q}, J=1.4 \mathrm{~Hz}, 1 \mathrm{H}, \mathrm{C}=\mathrm{CH}_{2}\right), 4.68\left(\mathrm{~d}, J=1.7 \mathrm{~Hz}, 1 \mathrm{H}, \mathrm{C}=\mathrm{CH}_{2}\right), 4.51(\mathrm{~s}, 2 \mathrm{H}$, $\left.\mathrm{PhCH} \mathrm{H}_{2} \mathrm{O}\right), 4.01\left(\mathrm{~s}, 2 \mathrm{H}, \mathrm{C}=\mathrm{CCH} \mathrm{C}_{2} \mathrm{O}\right), 3.86\left(\mathrm{~s}, 2 \mathrm{H}, \mathrm{ArCH}_{2}\right) .{ }^{13} \mathrm{C} \mathbf{N M R}\left(101 \mathrm{MHz}, \mathrm{CDCl}_{3}\right) \delta 173.0$, 145.5, 141.4, 138.2, 132.7, 131.9, 131.6, 129.0, 128.3, 127.7, 127.5, 126.4, 113.2, 73.2, 71.9, 37.6. IR 3065 (m), 3030 (m), 2911 (w), 2858 (m), 2718 (w), 2717 (w), 2657 (w), 2560 (w), 1774 (w), 1691 (s), $1654(\mathrm{w}), 1602(\mathrm{w}), 1576(\mathrm{w}), 1495(\mathrm{w}), 1455(\mathrm{w}), 1407(\mathrm{w}), 1365(\mathrm{w}), 1351(\mathrm{w})$, 1302 (m), 1272 (m), 1167 (w), 1138 (w), 1094 (m), 1075 (m), 1029 (w), 909 (m). HRMS (ESI) calcd for $\mathrm{C}_{18} \mathrm{H}_{17} \mathrm{O}_{3}{ }^{-}[\mathrm{M}+\mathrm{H}-1]^{-} 281.1183$; found 281.1187. Melting Point: 78.5-80.3 ${ }^{\circ} \mathrm{C}$.

\section{2-(1-(4-Chlororophenyl)vinyl)benzoic acid (1w)<smiles>C=C(c1ccc(Cl)cc1)c1ccccc1C(=O)O</smiles>

According to the general procedure, starting from 2-(4-chlorobenzoyl)benzoic acid (2.81 g, 10.8 mmol, $\quad 1.0$ equiv.), $\quad \mathrm{tBuOK} \quad(3.14 \mathrm{~g}, \quad 28.0 \mathrm{mmol}, 2.6$ equiv.) and bromo(methyl)triphenylphosphorane (5.00 g, $14.0 \mathrm{mmol}, 1.3$ equiv.), the product was obtained as a white solid 2 (1.3 g, $5.03 \mathrm{mmol}, 47 \%$ yield). ${ }^{1} \mathbf{H}$ NMR $\left(400 \mathrm{MHz}, \mathrm{CDCl}_{3}\right) \delta 7.95$ (dd, $J=7.8$, $1.4 \mathrm{~Hz}, 1 \mathrm{H}), 7.58(\mathrm{td}, J=7.5,1.4 \mathrm{~Hz}, 1 \mathrm{H}), 7.44(\mathrm{td}, J=7.6,1.3 \mathrm{~Hz}, 1 \mathrm{H}), 7.35(\mathrm{dd}, J=7.6,1.3$ $\mathrm{Hz}, 1 \mathrm{H}), 7.23-7.18(\mathrm{~m}, 2 \mathrm{H}), 7.16-7.11(\mathrm{~m}, 2 \mathrm{H}), 5.65\left(\mathrm{~d}, J=0.9 \mathrm{~Hz}, 1 \mathrm{H}, \mathrm{C}=\mathrm{CH}_{2}\right), 5.23(\mathrm{~d}, J=$ $\left.0.9 \mathrm{~Hz}, 1 \mathrm{H}, \mathrm{C}=\mathrm{CH}_{2}\right) .{ }^{13} \mathbf{C} \mathbf{N M R}\left(101 \mathrm{MHz}, \mathrm{CDCl}_{3}\right) \delta 172.0,148.5,143.2,139.4,133.3,132.7$, $131.5,130.9,129.1,128.2,128.0,127.9,114.7$. NMR data correspond to the reported values. ${ }^{[13]}$ 


\section{Photoredox Catalysis}

\section{a. General procedure for the photoredox catalysis.}

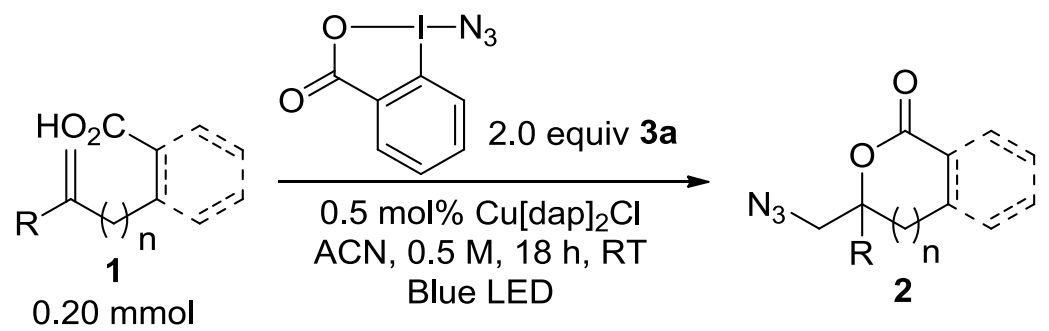

Dry acetonitrile $(1.0 \mathrm{~mL})$ degassed by bubbling nitrogen for $5 \mathrm{~min}$, was added in a flame dried 4 $\mathrm{mL}$ test tube containing a teflon coated stirring bar, the enoic acid $\mathbf{1}(0.20 \mathrm{mmol}, 1.0$ equiv), $\mathrm{ABX}$ reagent 3a (116 mg, $0.400 \mathrm{mmol}, 2.0$ equiv) and $\mathrm{Cu}\left[\mathrm{dap}_{2} \mathrm{Cl}(0.8 \mathrm{mg}, 0.9 \mu \mathrm{mol}, 0.5 \mathrm{~mol} \%)\right.$. The resulting solution was irradiated under stirring using blue light LEDs for $18 \mathrm{~h}$ at $\mathrm{rt}$. The reaction mixture was filtered, eluting with ethyl acetate, and evaporated under reduced pressure. The residue was purified by flash $\mathrm{SiO}_{2}$ column (Pentane/EtOAc : 100 to $90 / 10$ to 80/20) to give the corresponding azidolactone product 2. (The flash $\mathrm{SiO}_{2}$ column has to be deactivated by flashing mixture of pentane/Et $t_{3} N$ (95/5) before flashing $100 \%$ pentane).

\section{5-(Azidomethyl)-5-phenyldihydrofuran-2(3H)-one (2a)}<smiles>CCC1(c2ccccc2)CCC(=O)O1</smiles>

Starting from 4-phenylpent-4-enoic acid $1 \mathrm{a}$ (35 $\mathrm{mg}, 0.20 \mathrm{mmol}, 1.0$ equiv.), the crude product was purified by column chromatography (Pentane/EtOAc $=9: 1$ to $8 / 2$ ) to afford $\mathbf{2 a}$ as yellow solid (35 mg, 0.16 mmol, $81 \%$ yield). Rf: 0.45 (Pentane/Ethyl Acetate = 8:2) (Seebach Stain). ${ }^{1} \mathbf{H}$ NMR $\left(400 \mathrm{MHz}, \mathrm{CDCl}_{3}\right) \delta 7.44-7.32(\mathrm{~m}, 5 \mathrm{H}, \mathrm{ArH}), 3.68\left(\mathrm{~d}, J=13.2 \mathrm{~Hz}, 1 \mathrm{H}, \mathrm{CH}_{2} \mathrm{~N}_{3}\right), 3.53(\mathrm{~d}$, $\left.J=13.2 \mathrm{~Hz}, 1 \mathrm{H}, \mathrm{CH}_{2} \mathrm{~N}_{3}\right), 2.81-2.64\left(\mathrm{~m}, 2 \mathrm{H}, \mathrm{CH}_{2} \mathrm{CH}_{2}\right), 2.57-2.38\left(\mathrm{~m}, 2 \mathrm{H}, \mathrm{CH}_{2} \mathrm{CH}\right) .{ }^{13} \mathbf{C ~ N M R}$ $\left(101 \mathrm{MHz}, \mathrm{CDCl}_{3}\right) \delta 175.7,140.6,129.0,128.6,124.8,87.7,60.0,31.5,28.8$. NMR data correspond to the reported values. ${ }^{[18]}$

\section{5-(Azidomethyl)-5-(p-tolyl)dihydrofuran-2(3H)-one (2b)}<smiles>Cc1ccc(C2(CN)CCC(=O)O2)cc1</smiles>

Starting from 4-(p-tolyl)pent-4-enoic acid $\mathbf{1 b}(38 \mathrm{mg}, 0.20 \mathrm{mmol}, 1.0$ equiv.), the crude product was purified by column chromatography (Pentane/EtOAc $=9: 1$ to $8 / 2$ ) to afford $\mathbf{2 b}$ as pale yellow oil (38 mg, 0.16 mmol, $82 \%$ yield). Rf: 0.40 (Pentane/Ethyl Acetate = 8:2) (Seebach 
Stain). ${ }^{1} \mathbf{H}$ NMR $\left(400 \mathrm{MHz}, \mathrm{CDCl}_{3}\right) \delta 7.27(\mathrm{~d}, J=8.2 \mathrm{~Hz}, 2 \mathrm{H}, \mathrm{ArH}), 7.22(\mathrm{~d}, J=8.1 \mathrm{~Hz}, 2 \mathrm{H}$, $\mathrm{ArH}), 3.67\left(\mathrm{~d}, J=13.2 \mathrm{~Hz}, 1 \mathrm{H}, \mathrm{CH}_{2} \mathrm{~N}_{3}\right), 3.52\left(\mathrm{~d}, J=13.1 \mathrm{~Hz}, 1 \mathrm{H}, \mathrm{CH}_{2} \mathrm{~N}_{3}\right), 2.80-2.62(\mathrm{~m}, 2 \mathrm{H}$, $\left.\mathrm{CH}_{2} \mathrm{CH}_{2}\right), 2.59-2.39\left(\mathrm{~m}, 2 \mathrm{H}, \mathrm{CH}_{2} \mathrm{CH}_{2}\right), 2.36\left(\mathrm{~s}, 3 \mathrm{H}, \mathrm{CH}_{3}\right) .{ }^{13} \mathbf{C}$ NMR $\left(101 \mathrm{MHz}, \mathrm{CDCl}_{3}\right) \delta$ 176.0, 138.5, 137.5, 129.6, 124.7, 87.8, 60.0, 31.4, 28.8, 21.1. IR $v 3063$ (w), 3030 (w), 2923 (w), 2105 (s), 1779 (s), 1516 (w), 1280 (m), 1075 (m), 937 (m). HRMS (ESI) calcd for $\mathrm{C}_{12} \mathrm{H}_{13} \mathrm{~N}_{3} \mathrm{NaO}_{2}^{+}[\mathrm{M}+\mathrm{Na}]^{+}$254.0900; found 254.0903.

\section{5-(Azidomethyl)-5-(4-methoxyphenyl)dihydrofuran-2(3H)-one (2c)}<smiles>COc1ccc(C2(CN)CCC(=O)O2)cc1</smiles>

Starting from 4-(4-methoxyphenyl)pent-4-enoic acid 1c (41 mg, $0.20 \mathrm{mmol}, 1.0$ equiv.), the crude product was purified by column chromatography (Pentane/EtOAc $=9: 1$ to 8/2) to afford 2c as white solid (43 mg, $0.17 \mathrm{mmol}, 87 \%$ yield). Rf: 0.60 (Pentane/Ethyl Acetate = 7:3) (Seebach Stain). ${ }^{1} \mathbf{H}$ NMR $\left(400 \mathrm{MHz}, \mathrm{CDCl}_{3}\right) \delta 7.30(\mathrm{~d}, J=8.5 \mathrm{~Hz}, 2 \mathrm{H}, \mathrm{ArH}), 6.92(\mathrm{~d}, J=8.5 \mathrm{~Hz}, 2 \mathrm{H}$, $\mathrm{ArH}), 3.81\left(\mathrm{~s}, 3 \mathrm{H}, \mathrm{OCH}_{3}\right), 3.66\left(\mathrm{~d}, J=13.1 \mathrm{~Hz}, 1 \mathrm{H}, \mathrm{CH}_{2} \mathrm{~N}_{3}\right), 3.48\left(\mathrm{~d}, J=13.1 \mathrm{~Hz}, 1 \mathrm{H}, \mathrm{CH}_{2} \mathrm{~N}_{3}\right)$, $2.80-2.61\left(\mathrm{~m}, 2 \mathrm{H}, \mathrm{CH}_{2} \mathrm{CH}_{2}\right), 2.57-2.36\left(\mathrm{~m}, 2 \mathrm{H}, \mathrm{CH}_{2} \mathrm{CH}_{2}\right){ }^{13} \mathbf{C} \mathbf{N M R}\left(101 \mathrm{MHz}, \mathrm{CDCl}_{3}\right) \delta$ $175.8,159.8,132.5,126.2,114.3,87.6,60.2,55.5,31.4,28.9$. NMR data correspond to the reported values. ${ }^{[18]}$

\section{5-(Azidomethyl)-5-(4-bromophenyl)dihydrofuran-2(3H)-one (2d)}

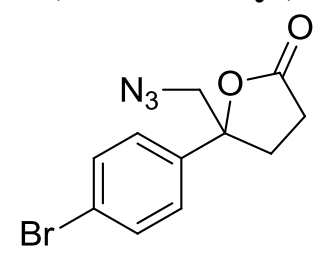

Starting from 4-(4-bromophenyl)pent-4-enoic acid 1d (51 g, $0.20 \mathrm{mmol}, 1.0$ equiv.), the crude product was purified by column chromatography (Pentane/EtOAc $=9: 1$ to 8/2) to afford $2 \mathbf{d}$ as pale yellow oil (46 mg, $0.15 \mathrm{mmol}, 78 \%$ yield). Rf: 0.43 (Pentane/ EtOAc = 8:2) (Seebach Stain). ${ }^{1}$ H NMR (400 MHz, $\left.\mathrm{CDCl}_{3}\right) \delta 7.62-7.52(\mathrm{~m}, 2 \mathrm{H}, \mathrm{ArH}), 7.29-7.21(\mathrm{~m}, 2 \mathrm{H}, \mathrm{ArH}), 3.66$ $\left(\mathrm{d}, J=13.2 \mathrm{~Hz}, 1 \mathrm{H}, \mathrm{CH}_{2} \mathrm{~N}_{3}\right), 3.52\left(\mathrm{~d}, J=13.2 \mathrm{~Hz}, 1 \mathrm{H}, \mathrm{CH}_{2} \mathrm{~N}_{3}\right), 2.84-2.64\left(\mathrm{~m}, 2 \mathrm{H}, \mathrm{CH}_{2} \mathrm{CH}_{2}\right)$, $2.53\left(\mathrm{~m}, 1 \mathrm{H}, \mathrm{CH}_{2} \mathrm{CH}_{2}\right), 2.40\left(\mathrm{~m}, 1 \mathrm{H}, \mathrm{CH}_{2} \mathrm{CH}_{2}\right) .{ }^{13} \mathrm{C}$ NMR $\left(101 \mathrm{MHz}, \mathrm{CDCl}_{3} d\right) \delta$ 175.4, 139.7, 132.1, 126.6, 122.8, 87.2, 59.8, 31.4, 28.7.NMR data correspond to the reported values. ${ }^{[18]}$

\section{5-(Azidomethyl)-5-(4-fluorophenyl)dihydrofuran-2(3H)-one (2e)}<smiles>NCC1(c2ccc(F)cc2)CCC(=O)O1</smiles>

Starting from 4-(4-fluorophenyl)pent-4-enoic acid 1e (39 mg, $0.20 \mathrm{mmol}, 1.0$ equiv.), the crude product was purified by column chromatography (Pentane/EtOAc $=9: 1$ to 8/2) to afford 2e as pale yellow solid (35 mg, $0.15 \mathrm{mmol}, 74 \%$ yield). Rf: 0.5 (Pentane/ EtOAc = 7:3) (Seebach Stain). ${ }^{1} \mathbf{H}$ NMR (400 MHz, $\left.\mathrm{CDCl}_{3}\right) \delta 7.40-7.33$ (m, 2H, ArH), $7.13-7.05$ (m, 2H, ArH), 3.65 
$\left(\mathrm{d}, J=13.0 \mathrm{~Hz}, 1 \mathrm{H}, \mathrm{CH}_{2} \mathrm{~N}_{3}\right), 3.51\left(\mathrm{~d}, J=13.2,1 \mathrm{H}, \mathrm{CH}_{2} \mathrm{~N}_{3}\right), 2.83-2.62\left(\mathrm{~m}, 2 \mathrm{H}, \mathrm{CH}_{2} \mathrm{CH}_{2}\right), 2.57-$ $2.48\left(\mathrm{~m}, 1 \mathrm{H}, \mathrm{CH}_{2} \mathrm{CH}_{2}\right), 2.45-2.36\left(\mathrm{~m}, 1 \mathrm{H}, \mathrm{CH}_{2} \mathrm{CH}_{2}\right) .{ }^{13} \mathbf{C}$ NMR $\left(101 \mathrm{MHz}, \mathrm{CDCl}_{3}\right) \delta 175.6$, $162.7(\mathrm{~d}, J=248.0 \mathrm{~Hz}), 136.4(\mathrm{~d}, J=3.2 \mathrm{~Hz}), 126.8(\mathrm{~d}, J=8.2 \mathrm{~Hz}), 115.9(\mathrm{~d}, J=21.7 \mathrm{~Hz}), 87.3$, 60.0, 31.5, 28.7. ${ }^{19}$ F NMR $\left(376 \mathrm{MHz}, \mathrm{CDCl}_{3}\right) \delta-113.14(\mathrm{~m}, 1 \mathrm{~F}) . \mathbf{I R} 3078(\mathrm{w}), 3078(\mathrm{w}), 3078$ (w), 2972 (w), 2932 (w), 2106 (s), 1783 (s), 1605 (w), 1512 (s), 1285 (m), 1232 (m). HRMS (ESI) calcd for $\mathrm{C}_{11} \mathrm{H}_{10} \mathrm{FN}_{3} \mathrm{NaO}_{2}{ }^{+}[\mathrm{M}+\mathrm{Na}]^{+} 258.0649$; found 258.0650 . Melting point: $71{ }^{\circ} \mathrm{C}$.

\section{Gram scale synthesis:}

Starting from 4-(4-fluorophenyl)pent-4-enoic acid 1e (1.00 g, $5.15 \mathrm{mmol}, 1.0$ equiv.), ABX 3a $\left(2.98 \mathrm{~g}, 10.30 \mathrm{mmol}, 2.0\right.$ equiv.) and $\mathrm{Cu}[\mathrm{dap}]_{2} \mathrm{Cl}(2.3 \mathrm{mg}, 2.50 \mu \mathrm{mol}, 0.05 \mathrm{~mol} \%)$. The crude product was purified by column chromatography (Pentane/EtOAc $=9: 1$ to $8 / 2$ ) to afford $2 \mathbf{e}$ as pale yellow solid (990 mg, $4.21 \mathrm{mmol}, 82 \%$ yield). (The flash $\mathrm{SiO}_{2}$ column has to be deactivated by flashing mixture of pentane/Et ${ }_{3} N(95 / 5)$ before flashing $100 \%$ pentane).

\section{5-(Azidomethyl)-5-(4-chlorophenyl)dihydrofuran-2(3H)-one (2f)}<smiles>NCC1(c2ccc(Cl)cc2)CCC(=O)O1</smiles>

Starting from 4-(4-chlorophenyl)pent-4-enoic acid $\mathbf{1 f}$ (42 $\mathrm{mg}, 0.20 \mathrm{mmol}, 1.0$ equiv.), the crude product was purified by column chromatography (Pentane/EtOAc $=9: 1$ to $8 / 2$ ) to afford $\mathbf{2 f}$ as pale yellow solid $(34 \mathrm{mg}, 0.13 \mathrm{mmol}, 68 \%$ yield). Rf: 0.45 (Pentane/ EtOAc $=7: 3$ ) (Seebach Stain). ${ }^{1} \mathbf{H}$ NMR $\left(400 \mathrm{MHz}, \mathrm{CDCl}_{3}\right) \delta 7.38(\mathrm{~d}, J=8.4 \mathrm{~Hz}, 2 \mathrm{H}, \mathrm{Ar} H), 7.32(\mathrm{~d}, J=8.6 \mathrm{~Hz}, 2 \mathrm{H}$, $\mathrm{Ar} H), 3.65\left(\mathrm{~d}, J=13.1,1 \mathrm{H}, \mathrm{CH}_{2} \mathrm{~N}_{3}\right), 3.51\left(\mathrm{~d}, J=13.2,1 \mathrm{H}, \mathrm{CH}_{2} \mathrm{~N}_{3}\right), 2.83-2.62(\mathrm{~m}, 2 \mathrm{H}$, $\left.\mathrm{CH}_{2} \mathrm{CH}_{2}\right), 2.52\left(\mathrm{~m}, 1 \mathrm{H}, \mathrm{CH}_{2} \mathrm{CH}_{2}\right), 2.39\left(\mathrm{~m}, 1 \mathrm{H}, \mathrm{CH}_{2} \mathrm{CH}_{2}\right) .{ }^{13} \mathbf{C} \mathbf{~ N M R}\left(101 \mathrm{MHz}, \mathrm{CDCl}_{3}\right) \delta 175.4$, $139.1,134.7,129.2,126.3,87.2,60.0,31.5,28.7$. NMR data correspond to the reported values. ${ }^{[18]}$

\section{3-(Azidomethyl)-3-methylisobenzofuran-1(3H)-one (2g)}<smiles>CC1(CN)OC(=O)c2ccccc21</smiles>

Starting from 2-(prop-1-en-2-yl)benzoic acid 1 g (32 mg, $0.20 \mathrm{mmol}, 1.0$ equiv.), the crude product was purified by column chromatography (Pentane/EtOAc $=9: 1$ to 8/2) to afford $2 \mathbf{g}$ as white solid (38 mg, 0.19 mmol, $94 \%$ yield). Rf: 0.55 (Pentane/ EtOAc = 8:2) (Seebach Stain). ${ }^{1}$ H NMR $\left(400 \mathrm{MHz}, \mathrm{CDCl}_{3}\right) \delta 7.91(\mathrm{~d}, J=7.6 \mathrm{~Hz}, 1 \mathrm{H}, \mathrm{ArH}), 7.70(\mathrm{t}, J=7.5 \mathrm{~Hz}, 1 \mathrm{H}, \mathrm{ArH}), 7.57$ $(\mathrm{t}, J=7.5 \mathrm{~Hz}, 1 \mathrm{H}, \mathrm{ArH}), 7.45(\mathrm{~d}, J=7.7 \mathrm{~Hz}, 1 \mathrm{H}, \mathrm{ArH}), 3.65\left(\mathrm{~m}, 2 \mathrm{H}, \mathrm{CH}_{2} \mathrm{~N}_{3}\right), 1.69\left(\mathrm{~s}, 3 \mathrm{H}, \mathrm{CH}_{3}\right)$.

${ }^{13}$ C NMR $\left(101 \mathrm{MHz}, \mathrm{CDCl}_{3}\right) \delta 169.1,150.8,134.5,129.8,126.1,126.1,121.3,85.8,58.1,23.2$. IR 3055 (w), 2985 (w), 2933 (w), 2105 (s), 1761 (s), 1468 (w), 1288 (m), 1035 (s). HRMS (ESI) calcd for $\mathrm{C}_{10} \mathrm{H}_{9} \mathrm{~N}_{3} \mathrm{NaO}_{2}{ }^{+}[\mathrm{M}+\mathrm{Na}]^{+} 226.0587$; found 226.0588 . Melting point : $77{ }^{\circ} \mathrm{C}$ 


\section{3-(Azidomethyl)-3-phenylisobenzofuran-1(3H)-one (1h)}<smiles>NCC1(c2ccccc2)OC(=O)c2ccccc21</smiles>

Starting from 2-(1-phenylvinyl)benzoic acid $\mathbf{1 h}(50 \mathrm{mg}, 0.20 \mathrm{mmol}, 1.0$ equiv.), the crude product was purified by column chromatography (Pentane/EtOAc $=9: 1$ to 8/2) to afford $\mathbf{2 h}$ as white solid (49 mg, 0.19 mmol, $92 \%$ yield). Rf: 0.8 (Pentane/ EtOAc = 7:3) (Seebach Stain). ${ }^{1} \mathbf{H}$ NMR $\left(400 \mathrm{MHz}, \mathrm{CDCl}_{3}\right) \delta 7.96(\mathrm{~d}, J=7.6 \mathrm{~Hz}, 1 \mathrm{H}, \mathrm{ArH}), 7.73(\mathrm{t}, J=7.5 \mathrm{~Hz}, 1 \mathrm{H}, \mathrm{ArH}), 7.61(\mathrm{~m}$, 2H, $\operatorname{ArH}), 7.53(\mathrm{~m}, 2 \mathrm{H}, \operatorname{ArH}), 7.39(\mathrm{~m}, 3 \mathrm{H}, \operatorname{Ar} H), 4.07\left(\mathrm{~d}, J=13.1 \mathrm{~Hz}, 1 \mathrm{H}, \mathrm{CH}_{2} \mathrm{~N}_{3}\right), 3.99(\mathrm{~d}, J=$ $\left.13.1 \mathrm{~Hz}, 1 \mathrm{H}, \mathrm{CH}_{2} \mathrm{~N}_{3}\right) .{ }^{13} \mathrm{C}$ NMR $\left(101 \mathrm{MHz}, \mathrm{CDCl}_{3}\right) \delta 169.2,149.6,137.3,134.7,130.2,129.3$, 129.23, 126.4, 126.3, 125.5, 122.9, 88.7, 58.3. IR 3069 (w), 2925 (w), 2854 (w), 2102 (s), 1773 (s), $1600(\mathrm{w}), 1467$ (m), $1288(\mathrm{~m}), 1103(\mathrm{~m}), 1017$ (m). HRMS (ESI) calcd for $\mathrm{C}_{15} \mathrm{H}_{11} \mathrm{~N}_{3} \mathrm{NaO}_{2}{ }^{+}$ $[\mathrm{M}+\mathrm{Na}]^{+} 288.0743$; found 288.0741 . Melting point : $90{ }^{\circ} \mathrm{C}$.

\section{3-(Azidomethyl)-3-(4-fluorophenyl)isobenzofuran-1(3H)-one (2i)}

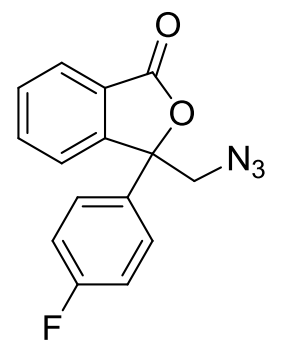

Starting from 2-(1-(4-fluorophenyl)vinyl)benzoic acid $1 \mathbf{i}$ (48 $\mathrm{mg}, 0.20 \mathrm{mmol}, 1.0$ equiv.), the crude product was purified by column chromatography (Pentane/EtOAc $=9: 1$ to 8/2) to afford $2 \mathbf{i}$ as yellow oil (51 mg, $0.18 \mathrm{mmol}, 91 \%$ yield). Rf: 0.55 (Pentane/ EtOAc = 8:2) (Seebach Stain). ${ }^{1} \mathbf{H}$ NMR $\left(400 \mathrm{MHz}, \mathrm{CDCl}_{3}\right) \delta 7.98(\mathrm{~m}, 1 \mathrm{H}, \mathrm{ArH}), 7.75(\mathrm{td}, J=7.5,1.1 \mathrm{~Hz}, 1 \mathrm{H}, \mathrm{ArH}), 7.62(\mathrm{~m}$, 2H, ArH), 7.53(m, 2H, ArH), $7.09(\mathrm{~m}, 2 \mathrm{H}, \mathrm{ArH}), 4.03\left(\mathrm{~d}, J=13.1 \mathrm{~Hz}, 1 \mathrm{H}, \mathrm{CH}_{2} \mathrm{~N}_{3}\right), 3.96(\mathrm{~d}, J=$ $\left.13.1 \mathrm{~Hz}, 1 \mathrm{H}, \mathrm{CH}_{2} \mathrm{~N}_{3}\right) .{ }^{13} \mathrm{C}$ NMR $\left(101 \mathrm{MHz} \mathrm{CDCl}_{3}\right) \delta 169.0,163.1(\mathrm{~d}, J=249.2 \mathrm{~Hz}), 149.4$, $134.8,133.2(\mathrm{~d}, J=3.3 \mathrm{~Hz}), 130.3,127.7(\mathrm{~d}, J=8.4 \mathrm{~Hz}), 126.6,126.3,122.8,116.2(\mathrm{~d}, J=21.7$ $\mathrm{Hz}), 88.1,58.3 .{ }^{19} \mathbf{F}$ NMR $\left(376 \mathrm{MHz}, \mathrm{CDCl}_{3}\right) \delta-112.12(\mathrm{~m}, 1 \mathrm{~F})$. IR $3079(\mathrm{w}), 2930(\mathrm{w}), 2104$ (s), 1770 (s), 1599 (w), 1512 (m), 1289 (m), 1242 (m). HRMS (ESI) calcd for $\mathrm{C}_{15} \mathrm{H}_{10} \mathrm{FN}_{3} \mathrm{NaO}_{2}{ }^{+}$ $[\mathrm{M}+\mathrm{Na}]^{+}$306.0649; found 306.0648

\section{5-(Azidomethyl)-3,3-dimethyl-5-phenyldihydrofuran-2(3H)-one (2j)}<smiles>CC1(C)CC(CN)(c2ccccc2)OC1=O</smiles>

Starting from 2,2-dimethyl-4-phenylpent-4-enoic acid $\mathbf{1 j}$ (41 $\mathrm{mg}, 0.20 \mathrm{mmol}, 1.0$ equiv.), the crude product was purified by column chromatography (Pentane/EtOAc $=9: 1$ to 8/2) to afford $\mathbf{2 j}$ as brown oil (44 mg, $0.17 \mathrm{mmol}, 90 \%$ yield). Rf: 0.55 (Pentane/ EtOAc = 8:2) (Seebach Stain). ${ }^{1}$ H NMR $\left(400 \mathrm{MHz}, \mathrm{CDCl}_{3}\right) \delta 7.44-7.30(\mathrm{~m}, 5 \mathrm{H}, \mathrm{Ar} H), 3.62\left(\mathrm{~d}, J=13.1 \mathrm{~Hz}, 1 \mathrm{H}, \mathrm{CH}_{2} \mathrm{~N}_{3}\right), 3.40$ 
$\left(\mathrm{d}, J=13.2 \mathrm{~Hz}, 1 \mathrm{H}, \mathrm{CH}_{2} \mathrm{~N}_{3}\right), 2.61\left(\mathrm{~d}, J=13.0 \mathrm{~Hz}, 1 \mathrm{H}, \mathrm{C}\left(\mathrm{CH}_{3}\right)_{2} \mathrm{CH}_{2}\right), 2.41(\mathrm{~d}, J=13.0 \mathrm{~Hz}, 1 \mathrm{H}$, $\left.\mathrm{C}\left(\mathrm{CH}_{3}\right)_{2} \mathrm{CH}_{2}\right), 1.36(\mathrm{~s}, 3 \mathrm{H}, \mathrm{CH}), 0.98\left(\mathrm{~s}, 3 \mathrm{H}, \mathrm{CH}_{3}\right) .{ }^{13} \mathrm{C}$ NMR $\left(101 \mathrm{MHz}, \mathrm{CDCl}_{3}\right) \delta 181.0,141.5$, 129.0, 128.5, 124.7, 84.6, 60.2, 45.3, 40.6, 26.5, 26.0. IR 3065 (w), 2975 (w), 2933 (w), 2874 (w), 2103 (s), 1772 (s), 1450 (m), 1253 (m), 1157 (m), 1053 (s). HRMS (ESI) calcd for $\mathrm{C}_{13} \mathrm{H}_{15} \mathrm{~N}_{3} \mathrm{NaO}_{2}^{+}[\mathrm{M}+\mathrm{Na}]^{+}$268.1056; found 268.1056.

\section{5-(Azidomethyl)-5-(thiophen-3-yl)dihydrofuran-2(3H)-one (2k)}<smiles>N#CC1(c2ccsc2)CCC(=O)O1</smiles>

Starting from 4-(thiophen-3-yl)pent-4-enoic acid 1k (25 mg, $0.12 \mathrm{mmol}, 1.0$ equiv.), ABX 3a (70 $\mathrm{mg}, 0.24 \mathrm{mmol}, 2.0$ equiv. $)$ and $\mathrm{Cu}[\mathrm{dap}]_{2} \mathrm{Cl}(0.5 \mathrm{mg}, 0.6 \mu \mathrm{mol}, 0.5 \mathrm{~mol} \%)$, the crude product was purified by column chromatography (Pentane/EtOAc $=9: 1$ to 8/2) to afford $2 \mathbf{k}$ as pale yellow oil $\left(22 \mathrm{mg}, 0.10 \mathrm{mmol}, 81 \%\right.$ yield). Rf: 0.45 (Pentane/ EtOAc = 7:3) (Seebach Stain). ${ }^{1} \mathbf{H}$ NMR $\left(400 \mathrm{MHz}, \mathrm{CDCl}_{3}\right) \delta 7.39(\mathrm{~m}, 1 \mathrm{H}, \operatorname{Ar} H), 7.31(\mathrm{~m}, 1 \mathrm{H}, \operatorname{Ar} H), 7.00(\mathrm{~m}, 1 \mathrm{H}, \operatorname{Ar} H), 3.71(\mathrm{~d}, J=13.1$ $\left.\mathrm{Hz}, 1 \mathrm{H}, \mathrm{CH}_{2} \mathrm{~N}_{3}\right), 3.53\left(\mathrm{~d}, \mathrm{~J}=13.1 \mathrm{~Hz}, 1 \mathrm{H}, \mathrm{CH}_{2} \mathrm{~N}_{3}\right), 2.78-2.51\left(\mathrm{~m}, 3 \mathrm{H}, \mathrm{CH}_{2} \mathrm{CH}_{2}\right), 2.40(\mathrm{~m}, 1 \mathrm{H}$, $\left.\mathrm{CH}_{2} \mathrm{CH}_{2}\right) .{ }^{13} \mathrm{C}$ NMR $\left(101 \mathrm{MHz}, \mathrm{CDCl}_{3} d\right) \delta 175.7,141.7,127.6,124.7,121.9,86.4,59.2,31.2$, 28.8. NMR data correspond to the reported values. ${ }^{[18]}$

\section{5-(Azidomethyl)-5-(2,5-dimethylphenyl)dihydrofuran-2(3H)-one (2I)}<smiles>Cc1ccc(C)c(C2(C)CCC(=O)O2)c1</smiles>

Starting from 4-(2,5-dimethylphenyl)pent-4-enoic acid 11 (41 mg, $0.20 \mathrm{mmol}, 1.0$ equiv.), the crude product was purified by column chromatography (Pentane/EtOAc $=9: 1$ to $8 / 2$ ) to afford $2 \mathbf{I}$ as pale yellow solid (35 mg, $0.14 \mathrm{mmol}, 71 \%$ yield). Rf: 0.48 (Pentane/ EtOAc $=8: 2$ ) (Seebach Stain). Two rotamers are observed in NMR analysis, however they are not fully resolved. Only the major rotamer is described. ${ }^{1} \mathbf{H}$ NMR $\left(400 \mathrm{MHz}, \mathrm{CDCl}_{3}\right) \delta 7.40-7.33(\mathrm{~m}, 1 \mathrm{H}, \mathrm{ArH}), 7.11-$ $6.99(\mathrm{~m}, 2 \mathrm{H}, \mathrm{ArH}), 3.67\left(\mathrm{~s}, 2 \mathrm{H}, \mathrm{CH}_{2} \mathrm{~N}_{3}\right), 2.86-2.69\left(\mathrm{~m}, 2 \mathrm{H}, \mathrm{CH}_{2} \mathrm{CH}_{2}\right), 2.61-2.44(\mathrm{~m}, 2 \mathrm{H}$, $\left.\mathrm{CH}_{2} \mathrm{CH}_{2}\right), 2.37\left(\mathrm{~m}, 3 \mathrm{H}, \mathrm{CH}_{3}\right), 2.32\left(\mathrm{~m}, 3 \mathrm{H}, \mathrm{CH}_{3}\right) .{ }^{13} \mathbf{C}$ NMR $\left(101 \mathrm{MHz}, \mathrm{CDCl}_{3}\right) \delta 175.8,138.3$, 136.2, 132.7, 130.4, 129.3, 126.5, 88.8, 58.9, 31.3, 29.0, 21.2, 21.1. IR 3027 (w), 2955 (w), 2359 (w), 2108 (s), 1783 (s), 1299 (w), $1190(\mathrm{~m})$. HRMS (ESI) calcd for $\mathrm{C}_{13} \mathrm{H}_{15} \mathrm{~N}_{3} \mathrm{NaO}_{2}{ }^{+}[\mathrm{M}+\mathrm{Na}]^{+}$ 268.1056; found 268.1064. Melting point : $61^{\circ} \mathrm{C}$.

\section{8b-(Azidomethyl)-3,3a,4,8b-tetrahydro-2H-indeno[1,2-b]furan-2-one (2m)}<smiles>NCC12OC(=O)CC1Cc1ccccc12</smiles>

Starting from 2-(1-methylene-2,3-dihydro-1H-inden-2-yl)acetic acid 1m (38 mg, $0.20 \mathrm{mmol}, 1.0$ equiv.), the crude product was purified by column chromatography (Pentane/EtOAc $=9: 1$ to 8/2) 
to afford $\mathbf{2 m}$ as pale yellow oil (30 mg, $0.13 \mathrm{mmol}, 65 \%$ yield). Rf: 0.5 (Pentane/ EtOAc $=7: 3$ ) (Seebach Stain). ${ }^{1} \mathbf{H}$ NMR (400 MHz, $\left.\mathrm{CDCl}_{3}\right) \delta 7.44-7.36(\mathrm{~m}, 2 \mathrm{H}, \mathrm{ArH}), 7.34-7.24(\mathrm{~m}, 2 \mathrm{H}$, $\operatorname{Ar} H), 3.96\left(\mathrm{~d}, J=13.1 \mathrm{~Hz}, 1 \mathrm{H}, \mathrm{CH}_{2} \mathrm{~N}_{3}\right), 3.52\left(\mathrm{~d}, J=13.1 \mathrm{~Hz}, 1 \mathrm{H}, \mathrm{CH}_{2} \mathrm{~N}_{3}\right), 3.34(\mathrm{dd}, J=16.5,8.3$ $\left.\mathrm{Hz}, 1 \mathrm{H}, \mathrm{ArCH}_{2} \mathrm{CH}\right), 3.27-3.17(\mathrm{~m}, 1 \mathrm{H}, \mathrm{CH}), 3.05\left(\mathrm{dd}, J=18.2,10.0 \mathrm{~Hz}, 1 \mathrm{H}, \mathrm{OCOCH}_{2} \mathrm{CH}\right)$, $2.86\left(\mathrm{dd}, J=16.6,2.9 \mathrm{~Hz}, 1 \mathrm{H}, \mathrm{ArCH}_{2} \mathrm{CH}\right), 2.40\left(\mathrm{dd}, J=18.2,6.3 \mathrm{~Hz}, 1 \mathrm{H}, \mathrm{OCOCH}_{2} \mathrm{CH}\right) .{ }^{13} \mathrm{C}$ NMR $\left(101 \mathrm{MHz}, \mathrm{CDCl}_{3}\right) \delta 175.7,142.2,138.9,130.7,128.0,125.8,124.8,96.0,56.2,40.3$, 37.4, 37.0. IR 3073 (w), 3030 (w), 2939 (w), 2860 (w), 2255 (w), 2108 (s), 1780 (s), 1194 (m), $956(\mathrm{~m}), 911$ (s). HRMS (ESI) calcd for $\mathrm{C}_{12} \mathrm{H}_{11} \mathrm{~N}_{3} \mathrm{NaO}_{2}{ }^{+}[\mathrm{M}+\mathrm{Na}]^{+}$252.0743; found 252.0748.

\section{5-(Azidomethyl)-5-(phenylethynyl)dihydrofuran-2(3H)-one (2n)}

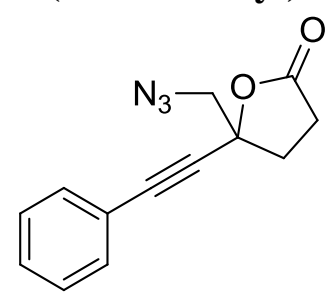

Starting from 4-methylene-6-phenylhex-5-ynoic acid $1 \mathrm{n}$ (40 mg, $0.20 \mathrm{mmol}, 1.0$ equiv.), the crude product was purified by column chromatography (Pentane/EtOAc $=9: 1$ to 8/2) to afford 2n as pale yellow oil (23 mg, $0.095 \mathrm{mmol}, 47 \%$ yield). Rf: 0.70 (Pentane/ EtOAc $=7: 3)$ (Seebach Stain). ${ }^{1}$ H NMR (400 MHz, $\left.\mathrm{CDCl}_{3}\right) \delta 7.50-7.42(\mathrm{~m}, 2 \mathrm{H}, \mathrm{ArH}), 7.40-7.30(\mathrm{~m}, 3 \mathrm{H}, \mathrm{ArH}), 3.77$ $\left(\mathrm{d}, J=13.0,1 \mathrm{H}, \mathrm{CH}_{2} \mathrm{~N}_{3}\right), 3.61\left(\mathrm{~d}, J=13.0,1 \mathrm{H}, \mathrm{CH}_{2} \mathrm{~N}_{3}\right), 2.89-2.78\left(\mathrm{~m}, 1 \mathrm{H}, \mathrm{CH}_{2} \mathrm{CH}_{2}\right), 2.75-$ $2.65\left(\mathrm{~m}, 1 \mathrm{H}, \mathrm{CH}_{2} \mathrm{CH}_{2}\right), 2.59-2.48\left(\mathrm{~m}, 2 \mathrm{H}, \mathrm{CH}_{2} \mathrm{CH}_{2}\right) .{ }^{13} \mathrm{C} \mathrm{NMR}\left(101 \mathrm{MHz}, \mathrm{CDCl}_{3}\right) \delta 175.27$, $132.0,129.5,128.6,121.1,88.1,85.3,80.0,57.9,32.3,28.8$. NMR data correspond to the reported values. ${ }^{[18]}$

\section{6-(Azidomethyl)-6-phenyltetrahydro-2H-pyran-2-one (2o)}<smiles>CCC1(c2ccccc2)CCCC(=O)O1</smiles>

Starting from 5-phenylhex-5-enoic acid 10 (38 mg, $0.20 \mathrm{mmol}, 1.0$ equiv.), the crude product was purified by column chromatography (Pentane/EtOAc $=9: 1$ to $8 / 2$ ) to afford 20 as pale yellow oil (15 mg, 0.065 mmol, $33 \%$ yield). Rf: 0.8 (Pentane/ EtOAc = 7:3) (Seebach Stain). ${ }^{1} \mathbf{H}$ NMR $\left(400 \mathrm{MHz}, \mathrm{CDCl}_{3}\right) \delta 7.45-7.31(\mathrm{~m}, 5 \mathrm{H}, \mathrm{Ar} H), 3.61\left(\mathrm{~d}, J=13.0 \mathrm{~Hz}, 1 \mathrm{H}, \mathrm{CH}_{2} \mathrm{~N}_{3}\right), 3.42(\mathrm{~d}, J=$ $\left.13.0 \mathrm{~Hz}, 1 \mathrm{H}, \mathrm{CH}_{2} \mathrm{~N}_{3}\right), 2.50\left(\mathrm{~m}, 2 \mathrm{H}, \mathrm{CH}_{2}\right), 2.25\left(\mathrm{~m}, 2 \mathrm{H}, \mathrm{CH}_{2}\right), 1.83\left(\mathrm{~m}, 1 \mathrm{H}, \mathrm{CH}_{2}\right), 1.60(\mathrm{~m}, 1 \mathrm{H}$, $\left.\mathrm{CH}_{2}\right) .{ }^{13} \mathrm{C}$ NMR $\left(101 \mathrm{MHz}, \mathrm{CDCl}_{3}\right) \delta 170.1,140.4,129.2,128.5,125.3,86.9,60.8,29.3,29.1$, 16.2. NMR data correspond to the reported values. ${ }^{[18]}$

\section{6-(Azidomethyl)-4,4-dimethyl-6-phenyltetrahydro-2H-pyran-2-one (2p)}<smiles>CC1(C)CC(=O)OC(CN)(c2ccccc2)C1</smiles> 
Starting from 3,3-dimethyl-5-phenylhex-5-enoic acid 1p (44 mg, $0.20 \mathrm{mmol}, 1.0$ equiv.), the crude product was purified by column chromatography (Pentane/EtOAc $=9: 1$ to 8/2) to afford 2p as colorless oil $(21 \mathrm{mg}, 0.081 \mathrm{mmol}, 42 \%$ yield). Rf: 0.43 (Pentane/ EtOAc = 8:2) (Seebach

Stain). ${ }^{1} \mathbf{H}$ NMR $\left(400 \mathrm{MHz}, \mathrm{CDCl}_{3}\right) \delta 7.45-7.28(\mathrm{~m}, 5 \mathrm{H}, \mathrm{ArH}), 3.50\left(\mathrm{~d}, J=12.9,1 \mathrm{H}, \mathrm{CH}_{2} \mathrm{~N}_{3}\right)$, $3.29\left(\mathrm{~d}, \mathrm{~J}=12.9 \mathrm{~Hz}, 1 \mathrm{H}, \mathrm{CH}_{2} \mathrm{~N}_{3}\right), 2.35-2.16\left(\mathrm{~m}, 4 \mathrm{H}, \mathrm{CH}_{2}\right), 1.10\left(\mathrm{~s}, 3 \mathrm{H}, \mathrm{CH}_{3}\right), 0.78(\mathrm{~s}, 3 \mathrm{H} \mathrm{CH})$. ${ }^{13}$ C NMR $\left(101 \mathrm{MHz}, \mathrm{CDCl}_{3}\right) \delta 171.1,141.6,129.0,128.3,125.1,85.8,62.0,43.8,41.7,31.9$, $30.7,29.1$. NMR data correspond to the reported values. ${ }^{[18]}$

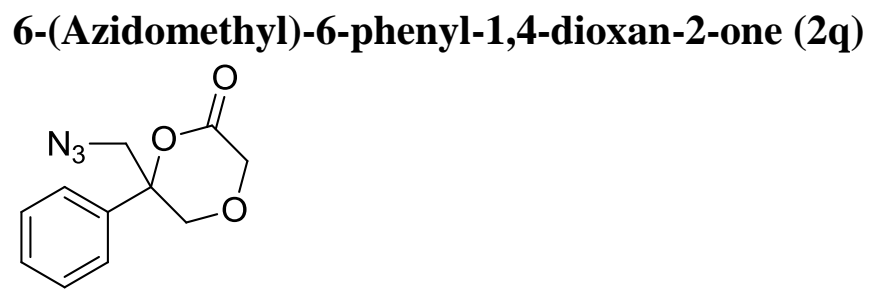

Starting from 2-((2-phenylallyl)oxy)acetic acid $\mathbf{1 q}(38 \mathrm{mg}, 0.20 \mathrm{mmol}, 1.0$ equiv.), the crude product was purified by column chromatography (Pentane/EtOAc $=9: 1$ to 8/2) to afford $\mathbf{2 q}$ as pale yellow oil $(25 \mathrm{mg}, 0.11 \mathrm{mmol}, 54 \%$ yield). Rf: 0.42 (Pentane/ EtOAc = 8:2) (Seebach Stain). ${ }^{1} \mathbf{H}$ NMR $\left(400 \mathrm{MHz}, \mathrm{CDCl}_{3}\right) \delta 7.47-7.36(\mathrm{~m}, 5 \mathrm{H}, \mathrm{ArH}), 4.44(\mathrm{~d}, J=17.7 \mathrm{~Hz}, 1 \mathrm{H}$, $\left.\mathrm{CO}_{2} \mathrm{CH}_{2} \mathrm{O}\right), 4.28\left(\mathrm{~d}, J=17.9 \mathrm{~Hz}, 1 \mathrm{H}, \mathrm{CO}_{2} \mathrm{CH}_{2} \mathrm{O}\right), 4.24\left(\mathrm{~d}, J=12.7 \mathrm{~Hz}, 1 \mathrm{H}, \mathrm{CCH}_{2} \mathrm{O}\right), 4.03(\mathrm{~d}, J=$ $\left.12.7 \mathrm{~Hz}, 1 \mathrm{H}, \mathrm{CCH}_{2} \mathrm{O}\right), 3.78\left(\mathrm{~d}, \mathrm{~J}=13.0 \mathrm{~Hz}, 1 \mathrm{H}, \mathrm{CH}_{2} \mathrm{~N}_{3}\right), 3.67\left(\mathrm{~d}, J=13.0 \mathrm{~Hz}, 1 \mathrm{H}, \mathrm{CH}_{2} \mathrm{~N}_{3}\right) .{ }^{13} \mathrm{C}$ NMR $\left(101 \mathrm{MHz}, \mathrm{CDCl}_{3}\right) \delta 166.2,137.5,129.2,129.1,125.1,84.6,67.9,65.7,57.3$. IR 3065 (w), 2875 (w), 2109 (s), 1762 (s), 1451 (w), 1262 (s), 1129 (m), 954 (w), 908 (m). HRMS (ESI) calcd for $\mathrm{C}_{11} \mathrm{H}_{11} \mathrm{~N}_{3} \mathrm{NaO}_{3}{ }^{+}[\mathrm{M}+\mathrm{Na}]+256.0693$; found 256.0690 . 


\section{Optimization for the Lewis-acid catalyzed cascade functionalization of alkenes}

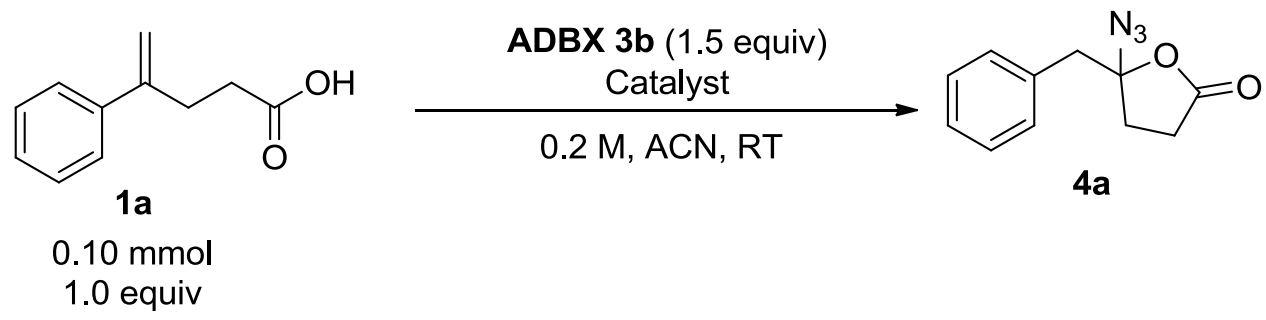

Dry acetonitrile $(0.5 \mathrm{~mL})$ was added in a flame dried $4 \mathrm{~mL}$ test tube containing a teflon coated stirring bar, the enoic acid 1 ( $0.10 \mathrm{mmol}, 1.0$ equiv), ADBX reagent $\mathbf{3 b}(45 \mathrm{mg}, 0.15 \mathrm{mmol}, 1.5$ equiv) and the catalyst. The resulting solution was stirred under $\mathrm{N}_{2}$ at room temperature for mentioned time. After completion of the reaction, the crude mixture was obtained after concentration under reduced pressure. Then addition of $6 \mu \mathrm{L}$ of $\mathrm{CH}_{2} \mathrm{Br}_{2}$ as internal standard gave NMR yield..

\begin{tabular}{|c|c|c|c|c|c|}
\hline Entry & Catalyst (10 mol\%) & Time & Concentration (M) & Conversion $^{[\mathrm{a}]}(\%)$ & Yield $^{[\mathrm{b}]}(\%)$ \\
\hline $1^{[c]}$ & $\mathrm{Pd}(\mathrm{OAc})_{2}$ & $15 \mathrm{~h}$ & 0.040 & 90 & 34 \\
\hline $2^{[c]}$ & $\mathrm{Pd}(\mathrm{TFA})_{2}$ & $15 \mathrm{~h}$ & 0.040 & 90 & 32 \\
\hline $3^{[c]}$ & $\mathrm{Pd}(\mathrm{OPiv})_{2}$ & $15 \mathrm{~h}$ & 0.040 & 90 & 32 \\
\hline 4 & $\mathrm{AgBF}_{4}$ & $15 \mathrm{~h}$ & 0.040 & $>95$ & 5 \\
\hline 5 & $\mathrm{Pd}(\mathrm{OAc})_{2}$ & $15 \mathrm{~h}$ & 0.040 & $>95$ & 53 \\
\hline 6 & $\mathrm{Pd}(\mathrm{acac})_{2}$ & $15 \mathrm{~h}$ & 0.040 & 25 & 48 \\
\hline 7 & $\mathrm{Pd}(\text { tfacac })_{2}$ & $15 \mathrm{~h}$ & 0.040 & $>95$ & 47 \\
\hline 8 & $\mathrm{Pd}(\text { hfacac })_{2}$ & $15 \mathrm{~h}$ & 0.040 & $>95$ & 60 \\
\hline $9^{[d]}$ & $\mathrm{Pd}(\text { hfacac })_{2}$ & $15 \mathrm{~h}$ & 0.040 & $>95$ & 10 \\
\hline 10 & $\mathrm{Pd}(\text { hfacac })_{2}$ & $15 \mathrm{~h}$ & 0.20 & $>95$ & 63 \\
\hline 11 & $\mathrm{Pd}(\text { hfacac })_{2}$ & $15 \mathrm{~h}$ & 0.40 & $>95$ & 59 \\
\hline 12 & $\mathrm{Pd}(\text { hfacac })_{2}$ & $5 \mathrm{~h}$ & 1.0 & $>95$ & 60 \\
\hline $13^{[\mathrm{e}]}$ & $\mathrm{Pd}(\text { hfacac })_{2}$ & $5 \mathrm{~h}$ & 0.20 & $>95$ & 57 \\
\hline $14^{[\mathrm{f}]}$ & $\mathrm{Pd}(\text { hfacac })_{2}$ & $5 \mathrm{~h}$ & 0.20 & $>95$ & 54 \\
\hline $15^{[\mathrm{g}]}$ & $\mathrm{Pd}(\text { hfacac })_{2}$ & $1 \mathrm{~h}$ & 0.20 & $>95$ & 60 \\
\hline 16 & $\ln (\mathrm{OTf})_{3}$ & $2 \mathrm{~h}$ & 0.20 & Low & 45 \\
\hline 17 & $\mathrm{Sn}(\mathrm{OTf})_{2}$ & $2 \mathrm{~h}$ & 0.20 & $>95$ & 85 \\
\hline 18 & $\mathrm{Zn}(\mathrm{OTf})_{2}$ & $2 \mathrm{~h}$ & 0.20 & $>95$ & 58 \\
\hline 19 & $\mathrm{Zn}\left(\mathrm{NTf}_{2}\right)_{2}$ & $2 \mathrm{~h}$ & 0.20 & $>95$ & $<5$ \\
\hline
\end{tabular}




\begin{tabular}{cccccc}
20 & $\mathrm{Zn}\left(\mathrm{BF}_{4}\right)_{2}, \mathrm{H}_{2} \mathrm{O}$ & $2 \mathrm{~h}$ & 0.20 & $>95$ & $<10$ \\
21 & $\mathrm{Sc}(\mathrm{OTf})_{3}$ & $2 \mathrm{~h}$ & 0.20 & $>95$ & 35 \\
$22^{[\mathrm{h}]}$ & $\mathrm{Sn}(\mathrm{OTf})_{2}$ & $2 \mathrm{~h}$ & 0.20 & $>95$ & 16 \\
$23^{[\mathrm{i}]}$ & $\mathrm{Sn}(\mathrm{OTf})_{2}$ & $2 \mathrm{~h}$ & 0.20 & $>95$ & 75 \\
$24^{[\mathrm{g}, \mathrm{i}]}$ & $\mathrm{Sn}(\mathrm{OTf})_{2}$ & $2 \mathrm{~h}$ & 0.20 & $>95$ & $80^{[\mathrm{k}]}$ \\
$25^{[\mathrm{h}]}$ & $\mathrm{Pd}(\mathrm{hfacac})_{2}$ & $2 \mathrm{~h}$ & 0.20 & $>95$ & 58 \\
$26^{[\mathrm{j]}}$ & $\mathrm{Pd}(\mathrm{hfacac})_{2}$ & $2 \mathrm{~h}$ & 0.20 & $>95$ & 75 \\
\hline
\end{tabular}

${ }^{[a]}$ The conversion of $\mathbf{5 a}$ by NMR is given. The reaction is stirred at RT unless otherwise noted. ${ }^{[b]} \mathrm{NMR}$ yield after using $6 \mu \mathrm{L} \mathrm{CH}_{2} \mathrm{Br}_{2}$ as internal standard. ${ }^{[\mathrm{c}]}$ In DCM ${ }^{[\mathrm{d}]}$ Using 1.5 equiv of $\mathrm{ABX}$ reagent. ${ }^{[\mathrm{e}]}$ At $50{ }^{\circ} \mathrm{C} .{ }^{[\mathrm{ff}]}$ At $0{ }^{\circ} \mathrm{C}$. ${ }^{[\mathrm{g}]}$

Using 2.0 equiv of ADBX reagent. ${ }^{[\mathrm{h}]} 20 \mathrm{~mol} \%$ catalyst ${ }^{[\mathrm{i}]} 5 \mathrm{~mol} \%$ catalyst ${ }^{[\mathrm{j}]} 2 \mathrm{~mol} \%$ catalyst ${ }^{[\mathrm{k}]}$ Issue of reproducibility using $\mathrm{Sn}(\mathrm{OTf})_{2}$ as catalyst. Reactions were performed several times yielding always very different outcomes, ranging from about 20 to $80 \%$ NMR yield. 


\section{Lewis acid catalyzed azidolactonization.}

\section{General Procedure}

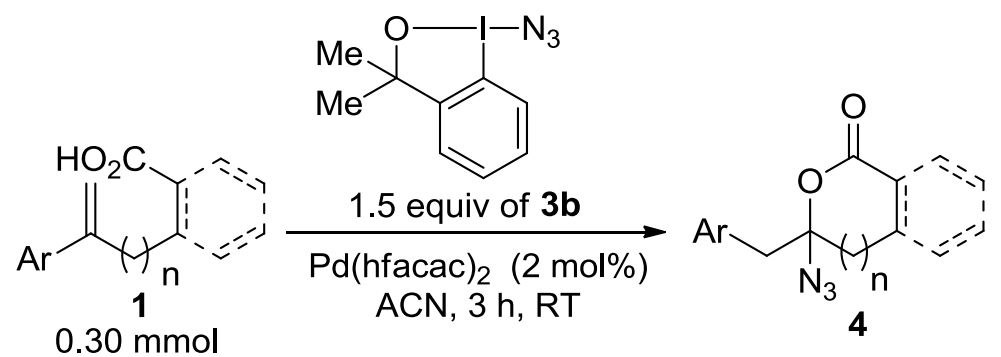

Dry acetonitrile $(1.5 \mathrm{~mL})$ was added in a flame dried $4 \mathrm{~mL}$ test tube containing a teflon coated stirring bar, the enoic acid 1 ( $0.30 \mathrm{mmol}, 1.0$ equiv), ADBX reagent $3 \mathbf{b}$ (136 $\mathrm{mg}, 0.450 \mathrm{mmol}$, 1.5 equiv) and $\operatorname{Pd}(\text { hfacac })_{2}(3.1 \mathrm{mg}, 6.0 \mu \mathrm{mol}, 0.02$ equiv.). The resulting solution was stirred under $\mathrm{N}_{2}$ at room temperature for $2 \mathrm{~h}$ unless otherwise noted. After completion of the reaction, the crude mixture was obtained after concentration under reduced pressure. Then addition of 18 $\mu \mathrm{L}$ of $\mathrm{CH}_{2} \mathrm{Br}_{2}$ as internal standard gave NMR yield. Final purification was performed by column chromatography (Pentane/EtOAc : 100 to $90 / 10$ to $80 / 20$ ) over silica gel affording the corresponding azidolactone product 4.

\section{5-Azido-5-benzyldihydrofuran-2(3H)-one (4a)}<smiles>NC1(Cc2ccccc2)CCC(=O)O1</smiles>

Starting from 1a $(53 \mathrm{mg}, 0.30 \mathrm{mmol})$, the crude product (75\% NMR yield) was purified by column chromatography (Pentane/Ethyl Acetate $=9: 1$ then 8:2) to afford 4a as colorless oil (34 $\mathrm{mg}, 0.16 \mathrm{mmol}, 52 \%) .{ }^{1} \mathbf{H}$ NMR $\left(400 \mathrm{MHz}, \mathrm{CDCl}_{3}\right) \delta 7.44-7.26(\mathrm{~m}, 5 \mathrm{H}, \mathrm{ArH}), 3.34(\mathrm{~d}, J=14.1$ $\left.\mathrm{Hz}, 1 \mathrm{H}, \mathrm{ArCH}_{2}\right), 3.23\left(\mathrm{~d}, \mathrm{~J}=14.1 \mathrm{~Hz}, 1 \mathrm{H}, \mathrm{ArCH}_{2}\right), 2.74-2.55\left(\mathrm{~m}, 1 \mathrm{H}, \mathrm{O}_{2} \mathrm{CCH}_{2} \mathrm{CH}_{2}\right), 2.31-$ $2.22\left(\mathrm{~m}, 1 \mathrm{H}, \mathrm{O}_{2} \mathrm{CCH}_{2} \mathrm{CH}_{2}\right), 2.23-2.16\left(\mathrm{~m}, 1 \mathrm{H}, \mathrm{O}_{2} \mathrm{CCH}_{2} \mathrm{CH}_{2}\right), 2.11-1.94(\mathrm{~m}, 1 \mathrm{H}$, $\left.\mathrm{O}_{2} \mathrm{CCH}_{2} \mathrm{CH}_{2}\right) .{ }^{13} \mathbf{C}$ NMR $\left(101 \mathrm{MHz}, \mathrm{CDCl}_{3}\right) \delta 174.7,133.1,130.4,128.7,127.8,99.4,43.7,31.3$, 28.3. IR 3033 (w), 2928 (w), 2858 (w), 2602 (w), 2477 (w), 2118 (s), 1796 (s), 1718 (w), 1490 (w), $1456(\mathrm{w}), 1424(\mathrm{w}), 1332(\mathrm{w}), 1248(\mathrm{~m}), 1167(\mathrm{~m}), 1085(\mathrm{w}), 1031(\mathrm{w}), 916(\mathrm{~m}), 875(\mathrm{w})$. HRMS (APPI) calcd for $\mathrm{C}_{11} \mathrm{H}_{12} \mathrm{NO}_{2}{ }^{+}\left[\mathrm{M}-\mathrm{N}_{2}+\mathrm{H}\right]^{+}$190.0863; found 190.0863.

\section{5-Azido-5-(4-bromobenzyl)dihydrofuran-2(3H)-one (4b)}

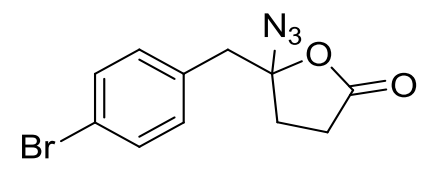

Starting from 4-(4-bromophenyl)pent-4-enoic acid 1d (51 mg, $0.20 \mathrm{mmol}, 1.0$ equiv.), ADBX reagent $3 \mathbf{b}$ (92 $\mathrm{mg}, 0.30 \mathrm{mmol}, 1.5$ equiv) and $\mathrm{Pd}(\mathrm{hfacac})_{2}(2.1 \mathrm{mg}, 4.0 \mu \mathrm{mol}, 0.02$ equiv.), the crude product ( $80 \%$ NMR yield) was purified by column chromatography (Pentane/EtOAc $=9: 1$ to $8 / 2$ ) to afford $\mathbf{4 b}$ as pale orange oil (31 mg, $0.11 \mathrm{mmol}, 53 \%$ yield). Rf: 0.40 (Pentane/ EtOAc = 8:2) $\left(\mathrm{KMnO}_{4}\right.$ Stain). ${ }^{1} \mathbf{H}$ NMR $\left(400 \mathrm{MHz} \mathrm{CDCl}_{3}\right) \delta 7.47(\mathrm{~m}, 2 \mathrm{H}, \mathrm{ArH}), 7.17(\mathrm{~m}, 2 \mathrm{H}, \mathrm{ArH})$, 3.29 (d, $J=14.2 \mathrm{~Hz}, 1 \mathrm{H}, \mathrm{CH}_{2} \mathrm{Ar}$ ), 3.18 (d, $J=14.2 \mathrm{~Hz}, 1 \mathrm{H}, \mathrm{CH}_{2} \mathrm{Ar}$ ), 2.68 (dt, $J=17.9,9.7 \mathrm{~Hz}$, $1 \mathrm{H}, \mathrm{O}_{2} \mathrm{CCH}_{2} \mathrm{CH}_{2}$ ), 2.33 (ddd, $\left.J=17.9,9.4,3.2 \mathrm{~Hz}, 1 \mathrm{H}, \mathrm{O}_{2} \mathrm{CCH}_{2} \mathrm{CH}_{2}\right), 2.15(\mathrm{~m}, 1 \mathrm{H}$, $\left.\mathrm{O}_{2} \mathrm{CCH}_{2} \mathrm{CH}_{2}\right), 2.03\left(\mathrm{ddd}, J=13.1,9.5,3.2 \mathrm{~Hz}, 1 \mathrm{H}, \mathrm{O}_{2} \mathrm{CCH}_{2} \mathrm{CH}_{2}\right) .{ }^{13} \mathrm{C} \mathrm{NMR}\left(101 \mathrm{MHz}, \mathrm{CDCl}_{3}\right)$ 
$\delta$ 174.7, 132.3, 132.2, 132.0, 122.2, 99.1, 43.3, 31.4, 28.3. IR 2990 (w), 2936 (w), $2116(\mathrm{~s}), 1796$ (s), $1493(\mathrm{~m}), 1249$ (m), 1165 (m), 1017 (m), 911 (s). HRMS (ESI) calcd for $\mathrm{C}_{11} \mathrm{H}_{11} \mathrm{BrNO}_{2}{ }^{+}[\mathrm{M}-$ $\left.\mathrm{N}_{2}+\mathrm{H}\right]^{+}$267.9973; found 267.9973.

\section{$1.5 \mathrm{mmol}$ scale synthesis:}

Starting from 4-(4-bromophenyl)pent-4-enoic acid 1d (400 mg, $1.57 \mathrm{mmol}, 1.0$ equiv.), ADBX $3 \mathbf{b}(713 \mathrm{mg}, 2.35 \mathrm{mmol}), 1.5$ equiv.) and $\mathrm{Pd}(\mathrm{hfacac})_{2}(16 \mathrm{mg}, 0.031 \mathrm{mmol}, 0.02$ equiv.). The crude product ( $80 \%$ NMR yield) was purified by column chromatography (Pentane/EtOAc $=9: 1$ to $8 / 2$ ) to afford $\mathbf{4 b}$ as pale orange oil ( $280 \mathrm{mg}, 0.946 \mathrm{mmol}, 60 \%$ yield).

\section{5-Azido-5-(4-fluorobenzyl)dihydrofuran-2(3H)-one (4c)}

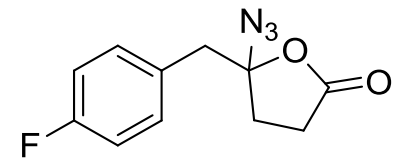

Starting from 4-(4-fluorophenyl)pent-4-enoic acid 1e (39 mg, $0.20 \mathrm{mmol}, 1.0$ equiv.), ADBX reagent $3 \mathbf{b}\left(92 \mathrm{mg}, 0.30 \mathrm{mmol}, 1.5\right.$ equiv) and $\mathrm{Pd}(\mathrm{hfacac})_{2}(2.1 \mathrm{mg}, 4.0 \mu \mathrm{mol}, 0.02$ equiv.), the crude product (68\% NMR yield) was purified by column chromatography (Pentane/EtOAc $=9: 1$ to $8 / 2)$ to afford $\mathbf{4 c}$ as pale yellow oil $(22 \mathrm{mg}, 0.094 \mathrm{mmol}, 46 \%$ yield). Rf: 0.40 (Pentane/ EtOAc = 8:2) $\left(\mathrm{KMnO}_{4}\right.$ Stain $) .{ }^{1} \mathbf{H}$ NMR $\left(400 \mathrm{MHz}, \mathrm{CDCl}_{3}\right) \delta 7.29(\mathrm{~m}, 2 \mathrm{H}, \mathrm{ArH}), 7.04(\mathrm{~m}, 2 \mathrm{H}$, $\mathrm{Ar} H$ ), $3.32\left(\mathrm{~d}, J=14.3 \mathrm{~Hz}, 1 \mathrm{H}, \mathrm{CH}_{2} \mathrm{Ar}\right), 3.21$ (d, $J=14.3 \mathrm{~Hz}, 1 \mathrm{H}, \mathrm{CH}_{2} \mathrm{Ar}$ ), 2.69 (dt, $J=17.8,9.6$ $\mathrm{Hz}, 1 \mathrm{H}, \mathrm{O}_{2} \mathrm{CCH}_{2} \mathrm{CH}_{2}$ ), 2.33 (ddd, $\left.J=17.8,9.4,3.1 \mathrm{~Hz}, 1 \mathrm{H}, \mathrm{O}_{2} \mathrm{CCH}_{2} \mathrm{CH}_{2}\right), 2.18(\mathrm{~m}, 1 \mathrm{H}$, $\left.\mathrm{O}_{2} \mathrm{CCH}_{2} \mathrm{CH}_{2}\right), 2.04\left(\mathrm{~m}, 1 \mathrm{H}, \mathrm{O}_{2} \mathrm{CCH}_{2} \mathrm{CH}_{2}\right) .{ }^{13} \mathbf{C} \mathbf{N M R}\left(101 \mathrm{MHz}, \mathrm{CDCl}_{3}\right) \delta 174.8,162.6(\mathrm{~d}, J=$ $247.0 \mathrm{~Hz}), 132.2(\mathrm{~d}, J=8.2 \mathrm{~Hz}), 129.0(\mathrm{~d}, J=3.3 \mathrm{~Hz}), 115.9(\mathrm{~d}, J=21.4 \mathrm{~Hz}), 99.3,43.1,31.5$, 28.3. ${ }^{19} \mathbf{F}$ NMR $\left(376 \mathrm{MHz}, \mathrm{CDCl}_{3}\right) \delta-114.28(\mathrm{~m}, 1 \mathrm{~F})$. IR $3048(\mathrm{w}), 2932(\mathrm{w}), 2116(\mathrm{~s}), 1796(\mathrm{~s})$, 1607 (w), 1513 (s), 1227 (s), 1161 (s), 911 (s). HRMS (ESI) calcd for $\mathrm{C}_{11} \mathrm{H}_{10} \mathrm{FN}_{3} \mathrm{NaO}_{2}{ }^{+}[\mathrm{M}+\mathrm{Na}]^{+}$ 258.0649; found 258.0655

\section{5-Azido-5-(4-chlorobenzyl)dihydrofuran-2(3H)-one (4d)}

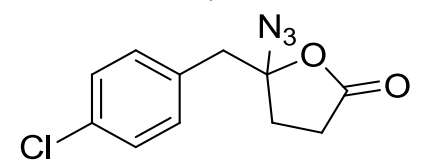

Starting from 4-(4-chlorophenyl)pent-4-enoic acid 1 f (42 mg, $0.20 \mathrm{mmol}, 1.0$ equiv.), ADBX reagent $3 \mathbf{b}$ (92 $\mathrm{mg}, 0.30 \mathrm{mmol}, 1.5$ equiv) and $\mathrm{Pd}(\mathrm{hfacac})_{2}(2.1 \mathrm{mg}, 4.0 \mu \mathrm{mol}, 0.02$ equiv.), the crude product ( $80 \%$ NMR yield) was purified by column chromatography (Pentane/EtOAc $=9: 1$ to $8 / 2$ ) to afford $4 d$ as pale yellow oil $(32 \mathrm{mg}, 0.13 \mathrm{mmol}, 63 \%$ yield). Rf: 0.38 (Pentane/ EtOAc = 8:2) $\left(\mathrm{KMnO}_{4}\right.$ Stain). ${ }^{1} \mathbf{H}$ NMR $\left(400 \mathrm{MHz} \mathrm{CDCl}_{3}\right) \delta 7.32(\mathrm{~m}, 2 \mathrm{H}, \mathrm{ArH}), 7.22(\mathrm{~m}, 2 \mathrm{H}, \operatorname{Ar} H)$, $3.31\left(\mathrm{~d}, J=14.2 \mathrm{~Hz}, 1 \mathrm{H}, \mathrm{CH}_{2} \mathrm{Ar}\right), 3.19$ (d, $J=14.2 \mathrm{~Hz}, 1 \mathrm{H}, \mathrm{CH}_{2} \mathrm{Ar}$ ), 2.68 (dt, $J=17.9,9.7 \mathrm{~Hz}$, $1 \mathrm{H}, \mathrm{O}_{2} \mathrm{CCH}_{2} \mathrm{CH}_{2}$ ), 2.33 (ddd, $\left.J=17.9,9.4,3.2 \mathrm{~Hz}, 1 \mathrm{H}, \mathrm{O}_{2} \mathrm{CCH}_{2} \mathrm{CH}_{2}\right), 2.15(\mathrm{~m}, 1 \mathrm{H}$, $\left.\mathrm{O}_{2} \mathrm{CCH}_{2} \mathrm{CH}_{2}\right), 2.03\left(\mathrm{~m}, 1 \mathrm{H}, \mathrm{O}_{2} \mathrm{CCH}_{2} \mathrm{CH}_{2}\right) .{ }^{13} \mathbf{C ~ N M R}\left(101 \mathrm{MHz}, \mathrm{CDCl}_{3}\right) \delta 174.6,134.0,131.8$, 131.6, 129.0, 99.1, 43.1, 31.3, 28.2. IR 2990 (w), 2936 (w), 2116 (s), 1796 (s), 1493 (m), 1249 (m), $1165(\mathrm{~m}), 1017(\mathrm{~m}), 911$ (s). HRMS (ESI) calcd for $\mathrm{C}_{11} \mathrm{H}_{11} \mathrm{ClNO}_{2}{ }^{+}\left[\mathrm{M}-\mathrm{N}_{2}+\mathrm{H}\right]^{+} 224.0484$; found 224.0480 .

\section{5-Azido-5-(4-methylbenzyl)dihydrofuran-2(3H)-one (4e)}


<smiles>Cc1ccc(CC2(N)CCC(=O)O2)cc1</smiles>

Starting from 4-(p-tolyl)pent-4-enoic acid $1 \mathbf{b}(73 \mathrm{mg}, 0.38 \mathrm{mmol}, 1.0$ equiv), using $4.0 \mathrm{mg}$ of $\operatorname{Pd}(\text { hfacac })_{2}(2 \mathrm{~mol} \%, 7.7 \mu \mathrm{mol})$ and $0.17 \mathrm{~g}$ of ADBX 3b (1.5 equiv., $\left.0.57 \mathrm{mmol}\right)$ the crude product (64\% NMR yield) was purified by column chromatography (Pentane/EtOAc $=9: 1$ to 8/2) to afford $4 \mathbf{e}$ as pale yellow oil $(42 \mathrm{mg}, 0.18 \mathrm{mmol}, 48 \%$ yield). Rf: 0.38 (Pentane/ EtOAc $=8: 2$ ) $\left(\mathrm{KMnO}_{4}\right.$ Stain). ${ }^{1} \mathbf{H}$ NMR $\left(400 \mathrm{MHz}, \mathrm{CDCl}_{3}\right) \delta 7.21-7.09(\mathrm{~m}, 4 \mathrm{H}, \mathrm{ArH}), 3.30(\mathrm{~d}, J=14.1 \mathrm{~Hz}$, $\left.1 \mathrm{H}, \mathrm{CH}_{2} \mathrm{Ar}\right), 3.18\left(\mathrm{~d}, J=14.2 \mathrm{~Hz}, 1 \mathrm{H}, \mathrm{CH}_{2} \mathrm{Ar}\right), 2.70-2.55\left(\mathrm{~m}, 1 \mathrm{H}, \mathrm{O}_{2} \mathrm{CCH}_{2} \mathrm{CH}_{2}\right), 2.34(\mathrm{~s}, 3 \mathrm{H}$, $\mathrm{Me}$ ), $2.30-2.14\left(\mathrm{~m}, 2 \mathrm{H}, \mathrm{O}_{2} \mathrm{CCH}_{2} \mathrm{CH}_{2}+\mathrm{O}_{2} \mathrm{CCH}_{2} \mathrm{CH}_{2}\right), 2.09-1.93\left(\mathrm{~m}, 1 \mathrm{H}, \mathrm{O}_{2} \mathrm{CCH}_{2} \mathrm{CH}_{2}\right) .{ }^{13} \mathrm{C}$ NMR $\left(101 \mathrm{MHz}, \mathrm{CDCl}_{3}\right) \delta 174.8,137.5,130.3,130.0,129.4,99.6,43.2,31.1,28.3,21.0$. IR $3564(\mathrm{w}), 3330$ (w), 3008 (w), $2925(\mathrm{w}), 2860(\mathrm{w}), 2454(\mathrm{w}), 2112(\mathrm{~s}), 1785$ (s), $1615(\mathrm{w}), 1516$ (w), $1454(\mathrm{w}), 1419(\mathrm{w}), 1383(\mathrm{w}), 1330(\mathrm{w}), 1247(\mathrm{~s}), 1159(\mathrm{~s}), 1116(\mathrm{w}), 1067(\mathrm{w}), 1029(\mathrm{~m})$, 911 (s), 875 (w), 847 (w), 822 (w). HRMS (ESI) calcd for $\mathrm{C}_{12} \mathrm{H}_{13} \mathrm{~N}_{3} \mathrm{NaO}_{2}{ }^{+}[\mathrm{M}+\mathrm{Na}]^{+} 254.0900$; found 254.0903 .

\section{5-Azido-5-(2,5-dimethylbenzyl)dihydrofuran-2(3H)-one (4f)<smiles>Cc1ccc(C)c(CC2(C)CCC(=O)O2)c1</smiles>

Starting from 11 (61 mg, $0.30 \mathrm{mmol}, 1.0$ equiv.), the crude product (55\% NMR yield) was purified by column chromatography (Pentane/EtOAc $=9: 1$ to $8 / 2$ ) to afford $4 \mathbf{f}$ as a mixture (40/60 by ${ }^{1} \mathrm{H}-\mathrm{NMR}$ ) with 2-(2-iodophenyl)propan-2-ol (74 $\mathrm{mg}$ total, $30 \mathrm{mg}$ of azidolactone calculated, 0.12 mmol, $40 \%$ yield). Rf: 0.30 (Pentane/ EtOAc = 8:2) $\left(\mathrm{KMnO}_{4}\right.$ Stain). Two rotamers are observed in NMR analysis, however they are not fully resolved. Only the major rotamer is described. ${ }^{1} \mathbf{H}$ NMR $\left(400 \mathrm{MHz} \mathrm{CDCl}_{3}\right) \delta 7.16-6.96(\mathrm{~m}, 3 \mathrm{H}, \mathrm{ArH}), 3.39(\mathrm{~d}, J=14.5$ $\mathrm{Hz}, 1 \mathrm{H}, \mathrm{CH}_{2} \mathrm{Ar}$ ), 3.19 (d, $J=14.4 \mathrm{~Hz}, 1 \mathrm{H}, \mathrm{CH}_{2} \mathrm{Ar}$ ), 2.66 (dt, $J=17.5,9.5 \mathrm{~Hz}, 1 \mathrm{H}, \mathrm{O}_{2} \mathrm{CCH}_{2} \mathrm{CH}_{2}$ ), $2.34(\mathrm{~s}, 3 \mathrm{H}, M e), 2.30(\mathrm{~s}, 3 \mathrm{H}, M e), 2.28-2.21\left(\mathrm{~m}, 1 \mathrm{H}, \mathrm{O}_{2} \mathrm{CCH}_{2} \mathrm{CH}_{2}\right), 2.21-2.13(\mathrm{~m}, 1 \mathrm{H}$, $\mathrm{O}_{2} \mathrm{CCH}_{2} \mathrm{CH}_{2}$ ), 2.07 (ddd, $\left.J=12.5,9.2,3.0 \mathrm{~Hz}, 1 \mathrm{H}, \mathrm{O}_{2} \mathrm{CCH}_{2} \mathrm{CH}_{2}\right) .{ }^{13} \mathbf{C}$ NMR $\left(101 \mathrm{MHz}, \mathrm{CDCl}_{3}\right)$ $\delta$ 174.7, 135.6, 134.2, 132.0, 131.3, 130.7, 128.6, 99.8, 40.0, 31.2, 28.2, 20.9, 19.6. HRMS (ESI) calcd for $\mathrm{C}_{13} \mathrm{H}_{16} \mathrm{~N}_{3} \mathrm{O}_{2}^{+}[\mathrm{M}-\mathrm{N} 2+\mathrm{H}]^{+} 218.1181$; found 218.1180 .

\section{2-(2-Iodophenyl)propan-2-ol}<smiles>CC(C)(O)c1ccccc1I</smiles>

${ }^{1}$ H NMR $\left(400 \mathrm{MHz}, \mathrm{CDCl}_{3}\right) \delta 7.96(\mathrm{dd}, J=7.8,1.4 \mathrm{~Hz}, 1 \mathrm{H}, \mathrm{ArH}), 7.63(\mathrm{dd}, J=8.0,1.7 \mathrm{~Hz}, 1 \mathrm{H}$, ArH), 7.33 (ddd, $J=7.9,7.3,1.4 \mathrm{~Hz}, 1 \mathrm{H}, \operatorname{Ar} H), 6.96-6.80(\mathrm{~m}, 1 \mathrm{H}, \operatorname{Ar} H), 2.41$ (s, 1H, OH), 1.76 (s, 6H, Me). ${ }^{13} \mathrm{C}$ NMR (101 MHz, $\left.\mathrm{CDCl}_{3}\right)$ 148.5, 142.7, 128.6, 128.1, 126.7, 93.1, 73.6, 29.8. NMR data correspond to the reported values. ${ }^{[29]}$

\section{5-Azido-5-(thiophen-3-ylmethyl)dihydrofuran-2(3H)-one (4g)}




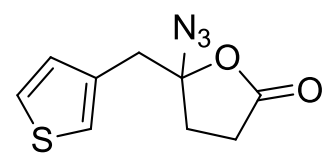

Starting from 1k (55 mg, $0.30 \mathrm{mmol}, 1.0$ equiv.), the crude product (60\% NMR yield) was purified by column chromatography (Pentane/Ethyl Acetate $=9: 1$ then 8:2) to afford $\mathbf{4 g}$ as colorless oil (34 mg, $0.16 \mathrm{mmol}, 52 \%) .{ }^{1} \mathbf{H} \mathbf{~ N M R}\left(400 \mathrm{MHz}, \mathrm{CDCl}_{3}\right) \delta 7.32(\mathrm{dd}, J=5.0,3.0 \mathrm{~Hz}$, $1 \mathrm{H}, \operatorname{Ar} H), 7.19(\mathrm{dd}, J=2.9,1.2 \mathrm{~Hz}, 1 \mathrm{H}, \operatorname{Ar} H), 7.05(\mathrm{dd}, J=4.9,1.3 \mathrm{~Hz}, 1 \mathrm{H}, \operatorname{Ar} H), 3.36(\mathrm{~d}, J=$ $\left.14.6 \mathrm{~Hz}, 1 \mathrm{H}, \mathrm{ArCH}_{2}\right), 3.29\left(\mathrm{~d}, J=14.6 \mathrm{~Hz}, 1 \mathrm{H}, \mathrm{ArCH}_{2}\right), 2.67(\mathrm{dt}, J=17.7,9.5 \mathrm{~Hz}, 1 \mathrm{H}$, $\mathrm{O}_{2} \mathrm{CCH}_{2} \mathrm{CH}_{2}$ ), 2.31 (ddd, $\left.J=17.7,9.5,3.4 \mathrm{~Hz}, 1 \mathrm{H}, \mathrm{O}_{2} \mathrm{CCH}_{2} \mathrm{CH}_{2}\right), 2.19$ (dt, $J=13.3,9.4 \mathrm{~Hz}, 1 \mathrm{H}$, $\mathrm{O}_{2} \mathrm{CCH}_{2} \mathrm{CH}_{2}$ ), 2.05 (ddd, $\left.J=13.2,9.6,3.4 \mathrm{~Hz}, 1 \mathrm{H}, \mathrm{O}_{2} \mathrm{CCH}_{2} \mathrm{CH}_{2}\right) .{ }^{13} \mathbf{C}$ NMR $\left(100 \mathrm{MHz}, \mathrm{CDCl}_{3}\right)$ $\delta$ 174.7, 133.2, 129.1, 126.3, 124.7, 99.1, 38.4, 31.4, 28.3. IR $3106(w), 2932(w), 2863(w)$, 2453 (w), 2254 (w), 2116 (s), 1793 (s), 1606 (w), 1451 (w), 1422 (w), 1242 (m), 1162 (s), 1075 (w), 1031 (m), 949 (w), $911(\mathrm{~s}), 848$ (w). HRMS (APCI) calcd for $\mathrm{C}_{9} \mathrm{H}_{10} \mathrm{NO}_{2} \mathrm{~S}^{+}\left[\mathrm{M}-\mathrm{N}_{2}+\mathrm{H}\right]^{+}$ 196.0427; found 196.0426.

\section{5-Azido-5-benzyl-3,3-dimethyldihydrofuran-2(3H)-one (4h)<smiles>CC1(C)CC(N)(Cc2ccccc2)OC1=O</smiles>

Starting from 2,2-dimethyl-4-phenylpent-4-enoic acid $\mathbf{1 j}$ (61 $\mathrm{mg}, 0.30 \mathrm{mmol}, 1.0$ equiv.), the crude product ( $81 \%$ NMR yield) was purified by column chromatography (Pentane/EtOAc $=9: 1$ to $8 / 2$ ) to afford $4 \mathrm{~h}$ as pale orange oil $(57 \mathrm{mg}, 0.23 \mathrm{mmol}, 77 \%$ yield). Rf: 0.50 (Pentane/ EtOAc = 8:2) $\left(\mathrm{KMnO}_{4}\right.$ Stain). ${ }^{1} \mathbf{H}$ NMR $\left(400 \mathrm{MHz} \mathrm{CDCl}_{3}\right) \delta 7.37-7.22(\mathrm{~m}, 5 \mathrm{H}), 3.33(\mathrm{~d}, J=14.1 \mathrm{~Hz}$, $\left.1 \mathrm{H}, \mathrm{CH}_{2} \mathrm{Ar}\right), 3.20\left(\mathrm{~d}, J=14.1 \mathrm{~Hz}, 1 \mathrm{H}, \mathrm{CH}_{2} \mathrm{Ar}\right), 2.10\left(\mathrm{~d}, J=13.7 \mathrm{~Hz}, 1 \mathrm{H}, \mathrm{CCH}_{2} \mathrm{CMe}_{2}\right), 1.92(\mathrm{~d}, J$ $\left.=13.8 \mathrm{~Hz}, 1 \mathrm{H}, \mathrm{CCH}_{2} \mathrm{CMe}_{2}\right), 1.35\left(\mathrm{~s}, 3 \mathrm{H}, \mathrm{CH}_{3}\right), 0.99\left(\mathrm{~s}, 3 \mathrm{H}, \mathrm{CH}_{3}\right) .{ }^{13} \mathbf{C} \mathbf{N M R}\left(101 \mathrm{MHz}, \mathrm{CDCl}_{3}\right)$ $\delta$ 180.6, 133.4, 130.7, 128.8, 127.9, 96.5, 44.9, 44.4, 40.4, 26.5, 26.0. IR 3065 (w), $2976(w)$, 2934 (w), 2114 (s), 1785 (s), 1456 (w), 1258 (m), 1229 (s), 1129 (m), 1037 (m), 908 (s). HRMS (ESI) calcd for $\mathrm{C}_{13} \mathrm{H}_{15} \mathrm{~N}_{3} \mathrm{NaO}_{2}^{+}[\mathrm{M}+\mathrm{Na}]^{+}$268.1056; found 268.1056.

\section{3-Azido-3-benzylisobenzofuran-1(3H)-one (4i)}<smiles>NC1(Cc2ccccc2)OC(=O)c2ccccc21</smiles>

Starting from 2-(1-phenylvinyl)benzoic acid 1 h $(67 \mathrm{mg}, 0.30 \mathrm{mmol}, 1.0$ equiv.), the crude product (75\% NMR yield) was purified by column chromatography (Pentane/EtOAc $=9: 1$ to 8/2) to afford $4 \mathbf{i}$ as a mixture (60/40 by ${ }^{1} \mathrm{H}-\mathrm{NMR}$ ) with 2-(2-iodophenyl)propan-2-ol (98 $\mathrm{mg}$ total, 59 $\mathrm{mg}$ of azidolactone calculated, $0.22 \mathrm{mmol}, 74 \%$ yield). Rf: 0.30 (Pentane/ EtOAc = 8:2) $\left(\mathrm{KMnO}_{4}\right.$ Stain/UV). ${ }^{1} \mathbf{H}$ NMR $\left(400 \mathrm{MHz}, \mathrm{CDCl}_{3}\right) \delta 7.77(\mathrm{dd}, J=7.6,0.9 \mathrm{~Hz}, 1 \mathrm{H}, \mathrm{ArH}), 7.71(\mathrm{td}$, $J=7.6,1.1 \mathrm{~Hz}, 1 \mathrm{H}, \operatorname{Ar} H), 7.56(\mathrm{td}, J=7.5,1.0 \mathrm{~Hz}, 1 \mathrm{H}, \operatorname{Ar} H), 7.38(\mathrm{~d}, J=7.7 \mathrm{~Hz}, 1 \mathrm{H}, \operatorname{Ar} H)$, 7.19 (dd, $J=5.0,2.0 \mathrm{~Hz}, 3 \mathrm{H}, \mathrm{ArH}), 7.09$ (dd, $J=6.7,3.0 \mathrm{~Hz}, 2 \mathrm{H}, \mathrm{ArH}), 3.38$ (s, 2H, CH. $\mathrm{Ar}$ ). ${ }^{13} \mathrm{C}$ NMR $\left(101 \mathrm{MHz}, \mathrm{CDCl}_{3}\right) \delta 167.1,148.5,134.6,132.3,130.9,130.7,128.2,127.5,126.2$, 125.7, 122.6, 98.8, 44.2. HRMS (ESI) calcd for $\mathrm{C}_{15} \mathrm{H}_{12} \mathrm{~N}_{3} \mathrm{O}_{2}{ }^{+}[\mathrm{M}-\mathrm{N} 2+\mathrm{H}]^{+}$238.0868; found 238.0873 . 


\section{3-Azido-3-(4-chlorobenzyl)isobenzofuran-1(3H)-one (4j)}<smiles>NC1(Cc2ccc(Cl)cc2)OC(=O)c2ccccc21</smiles>

Starting from 2-(1-(4-chlorophenyl)vinyl)benzoic acid $1 \mathbf{w}$ (78 $\mathrm{mg}, 0.30 \mathrm{mmol}, 1.0$ equiv.), the crude product (78\% NMR yield) was purified by column chromatography (Pentane/EtOAc $=9: 1$ to $8 / 2$ ) to afford $\mathbf{4 j}$ as pale yellow oil $(67 \mathrm{mg}, 0.22 \mathrm{mmol}, 74 \%$ yield). Rf: 0.25 (Pentane/ EtOAc $=8: 2)\left(\mathrm{KMnO}_{4}\right.$ Stain/UV). ${ }^{1} \mathbf{H}$ NMR $\left(400 \mathrm{MHz}, \mathrm{CDCl}_{3}\right) \delta 7.80(\mathrm{~d}, J=7.7 \mathrm{~Hz}, 1 \mathrm{H}, \operatorname{Ar} H), 7.73$ $(\operatorname{td}, J=7.5,1.1 \mathrm{~Hz}, 1 \mathrm{H}, \operatorname{Ar} H), 7.59(\mathrm{td}, J=7.6,0.9 \mathrm{~Hz}, 1 \mathrm{H}, \operatorname{Ar} H), 7.41(\mathrm{dd}, J=7.7,0.9 \mathrm{~Hz}, 1 \mathrm{H}$, $\operatorname{Ar} H), 7.17(\mathrm{~d}, J=8.4 \mathrm{~Hz}, 2 \mathrm{H}, \mathrm{ArH}), 7.03(\mathrm{~d}, J=8.4 \mathrm{~Hz}, 2 \mathrm{H}, \mathrm{ArH}), 3.41-3.26\left(\mathrm{~m}, 2 \mathrm{H}, \mathrm{ArCH}_{2}\right)$. ${ }^{13}$ C NMR $\left(101 \mathrm{MHz}, \mathrm{CDCl}_{3}\right) \delta 166.9,145.9,134.9,133.7,132.0,131.2,130.9,128.5,126.3$, 126.0, 122.5, 98.5, 43.7. IR 3553 (w), 3064 (w), 2840 (w), 2433 (w), 2116 (s), 1784 (s), 1602 (w), $1493(\mathrm{w}), 1469(\mathrm{w}), 1435(\mathrm{w}), 1410(\mathrm{w}), 1349(\mathrm{w}), 1275(\mathrm{~m}), 1239(\mathrm{~m}), 1209(\mathrm{w}), 1160(\mathrm{w})$, $1087(\mathrm{~m}), 1014(\mathrm{w}), 956(\mathrm{~m}), 906(\mathrm{w}), 844(\mathrm{w}), 817$ (w). HRMS (ESI) calcd for $\mathrm{C}_{15} \mathrm{H}_{10} \mathrm{ClNO}_{2}{ }^{+}$ [M-N2+H] ${ }^{+}$272.0478; found 272.0481.

\section{3-Azido-3-(4-fluorobenzyl)isobenzofuran-1(3H)-one (4k)}<smiles>Cc1ccccc1C1(C)NOC1(C)Cc1ccc(F)cc1</smiles>

Starting from 2-(1-(4-Fluorophenyl)vinyl)benzoic acid 1i, the crude product (75\% NMR yield) was purified by column chromatography (Pentane/EtOAc $=9: 1$ to $8 / 2$ ) to afford $\mathbf{4 k}$ as a mixture (40/60 by $\left.{ }^{1} \mathrm{H}-\mathrm{NMR}\right)$ with 2-(2-iodophenyl)propan-2-ol (122 $\mathrm{mg}$ total, $51 \mathrm{mg}$ of azidolactone calculated, $0.18 \mathrm{mmol}, 60 \%$ yield). Rf: $0.30($ Pentane/ EtOAc $=8: 2)\left(\mathrm{KMnO}_{4} \mathrm{Stain} / \mathrm{UV}\right)$. Always used directly as crude material for product modification. ${ }^{1} \mathbf{H} \mathbf{~ N M R}\left(400 \mathrm{MHz}, \mathrm{CDCl}_{3}\right) \delta$ $7.79(\mathrm{~d}, J=7.6 \mathrm{~Hz}, 1 \mathrm{H}, \operatorname{Ar} H), 7.73(\mathrm{td}, J=7.5,1.1 \mathrm{~Hz}, 1 \mathrm{H}, \operatorname{Ar} H), 7.57(\mathrm{t}, J=7.6 \mathrm{~Hz}, 1 \mathrm{H}, \operatorname{Ar} H)$, $7.40(\mathrm{~d}, J=7.7 \mathrm{~Hz}, 1 \mathrm{H}, \operatorname{Ar} H), 7.11-7.01(\mathrm{~m}, 2 \mathrm{H}, \operatorname{Ar} H), 6.87(\mathrm{~d}, J=8.5 \mathrm{~Hz}, 2 \mathrm{H}, \operatorname{Ar} H), 3.38(\mathrm{~d}, J$ $\left.=14.2 \mathrm{~Hz}, 1 \mathrm{H}, \mathrm{CH}_{2} \mathrm{Ar}\right), 3.32\left(\mathrm{~d}, J=14.2 \mathrm{~Hz}, 1 \mathrm{H}, \mathrm{CH}_{2} \mathrm{Ar}\right) .{ }^{13} \mathbf{C} \mathbf{~ N M R}\left(101 \mathrm{MHz}, \mathrm{CDCl}_{3}\right) \delta 167.0$, $162.3(\mathrm{~d}, J=246.3 \mathrm{~Hz}), 145.9,134.8,132.3(\mathrm{~d}, J=8.1 \mathrm{~Hz}), 131.1,128.1$ (overlapping with 2-(2iodophenyl)propan-2-ol), 126.3, 125.9, 122.5, $115.2(\mathrm{~d}, J=21.3 \mathrm{~Hz}), 98.7,43.5 .{ }^{19} \mathbf{F}$ NMR (376 $\left.\mathrm{MHz}, \mathrm{CDCl}_{3}\right) \delta 114.51(\mathrm{~m}, 1 \mathrm{~F})$. HRMS (ESI) calcd for $\mathrm{C}_{15} \mathrm{H}_{11} \mathrm{FNO}_{2}{ }^{+}[\mathrm{M}-\mathrm{N} 2+\mathrm{H}]^{+}$256.0768; found 256.0779 . 


\section{Pd-Catalyzed Synthesis of (1,2)-Azidolactones}

\section{General procedure}

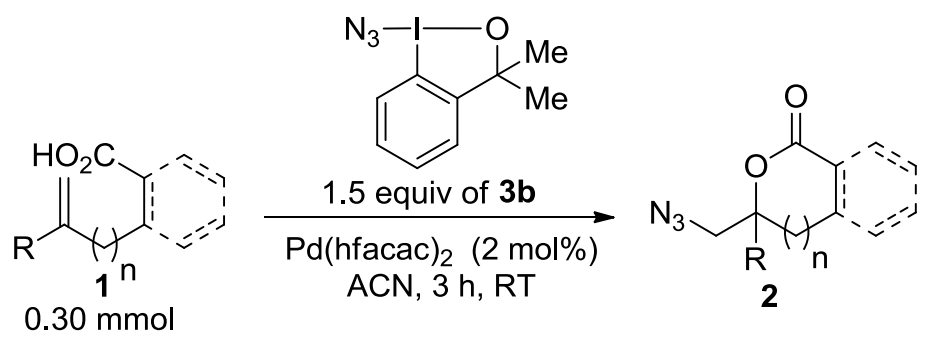

Dry acetonitrile $(1.5 \mathrm{~mL})$ was added in a flame dried $4 \mathrm{~mL}$ test tube containing a teflon coated stirring bar, the enoic acid 1 ( $0.30 \mathrm{mmol}, 1.0$ equiv), ADBX reagent $\mathbf{3 b}$ (136 $\mathrm{mg}, 0.450 \mathrm{mmol}$, 1.5 equiv) and $\operatorname{Pd}(\mathrm{hfacac})_{2}(3.1 \mathrm{mg}, 6.0 \mu \mathrm{mol}, 0.02$ equiv.). The resulting solution was stirred under $\mathrm{N}_{2}$ at room temperature for $2 \mathrm{~h}$ unless otherwise noted. After completion of the reaction, the crude mixture was obtained after concentration under reduced pressure. Final purification was performed by column chromatography (Pentane/EtOAc : 100 to $90 / 10$ to $80 / 20$ ) over silica gel affording the corresponding azidolactone product 2 .

\section{5-(Azidomethyl)-5-(3-phenylpropyl)dihydrofuran-2(3H)-one (2s)}<smiles>N#CC1(CCCc2ccccc2)CCC(=O)O1</smiles>

Starting from 4-Methylene-7-phenylheptanoic acid $1 \mathrm{~s}$ (55 $\mathrm{mg}, 0.25 \mathrm{mmol}, 1.0$ equiv.), $\operatorname{Pd}(\text { hfacac })_{2}(2.6 \mathrm{mg}, 5.0 \mu \mathrm{mol}, 0.02$ equiv), ADBX 3b (115 mg, $0.378 \mathrm{mmol}, 1.5 \mathrm{equiv})$, the crude product (40\% NMR yield, using $5 \mu \mathrm{L}$ of $\mathrm{CH}_{2} \mathrm{Br}_{2}$ as internal standard) was purified by column chromatography (Pentane/Ethyl Acetate $=9: 1$ then 8:2) to afford $2 \mathbf{s}$ as colorless oil (13 $\mathrm{mg}, 0.050 \mathrm{mmol}, 20 \%$ yield). ${ }^{1} \mathbf{H}$ NMR $\left(400 \mathrm{MHz}, \mathrm{CDCl}_{3}\right) \delta 7.29(\mathrm{dd}, J=8.1,6.6 \mathrm{~Hz}, 2 \mathrm{H}$, $\mathrm{ArH}), 7.24-7.18(\mathrm{~m}, 1 \mathrm{H}, \mathrm{ArH}), 7.18-7.13(\mathrm{~m}, 2 \mathrm{H}, \mathrm{ArH}), 3.51\left(\mathrm{~d}, J=12.8 \mathrm{~Hz}, 1 \mathrm{H}, \mathrm{CH}_{2} \mathrm{~N}_{3}\right)$, $3.35\left(\mathrm{~d}, J=12.8 \mathrm{~Hz}, 1 \mathrm{H}, \mathrm{CH}_{2} \mathrm{~N}_{3}\right), 2.76-2.66\left(\mathrm{~m}, 1 \mathrm{H}, \mathrm{O}_{2} \mathrm{CCH}_{2} \mathrm{CH}_{2}\right), 2.66-2.61(\mathrm{~m}, 2 \mathrm{H}$, $\mathrm{ArCH}_{2} \mathrm{CH}_{2} \mathrm{CH}_{2}$ ), 2.55 (ddd, $J=18.2,10.6,5.9 \mathrm{~Hz}, 1 \mathrm{H}, \mathrm{O}_{2} \mathrm{CCH}_{2} \mathrm{CH}_{2}$ ), 2.16 (ddd, $J=13.3,10.7$, $\left.5.9 \mathrm{~Hz}, 1 \mathrm{H}, \mathrm{O}_{2} \mathrm{CCH}_{2} \mathrm{CH}_{2}\right), 1.99\left(\mathrm{ddd}, J=13.3,10.6,7.4 \mathrm{~Hz}, 1 \mathrm{H}, \mathrm{O}_{2} \mathrm{CCH}_{2} \mathrm{CH}_{2}\right), 1.78-1.64(\mathrm{~m}$, $\left.4 \mathrm{H}, \mathrm{ArCH}_{2} \mathrm{CH}_{2} \mathrm{CH}_{2}\right) .{ }^{13} \mathrm{C}$ NMR $\left(100 \mathrm{MHz} \mathrm{CDCl}_{3}\right) \delta 176.1,141.2,128.5,128.3,126.1,86.6$, 57.7, 37.2, 35.7, 28.9, 28.6, 25.0. IR 3061 (w), 3028 (w), 2945 (w), 2869 (w), 2108 (s), 1777 (s), 1604 (w), 1495 (w), 1455 (w), 1281 (m), 1241 (m), 1198 (m), 1168 (m), 1083 (w), 1027 (w), 946 $(\mathrm{m}), 917(\mathrm{w}), 847(\mathrm{w})$. HRMS (ESI) calcd for $\mathrm{C}_{14} \mathrm{H}_{17} \mathrm{~N}_{3} \mathrm{NaO}_{2}{ }^{+}[\mathrm{M}+\mathrm{Na}]^{+}$282.1213; found 282.1215 .

\section{3-(Azidomethyl)-3-methylisobenzofuran-1(3H)-one (2g)}<smiles>CC1(CN)OC(=O)c2ccccc21</smiles>

Starting from 2-(prop-1-en-2-yl)benzoic acid $1 \mathrm{~g}$ (32 $\mathrm{mg}, 0.20 \mathrm{mmol}, 1.0$ equiv.), ADBX reagent 3b (92 mg, $0.30 \mathrm{mmol}, 1.5$ equiv) and $\mathrm{Pd}(\text { hfacac })_{2}(2.1 \mathrm{mg}, 4.0 \mu \mathrm{mol}, 0.02$ equiv.), the crude 
product was purified by column chromatography (Pentane/EtOAc $=9: 1$ to 8/2) to afford $\mathbf{2 g}$ as white solid (20 mg, $0.104 \mathrm{mmol}, 50 \%$ yield). Rf: 0.55 (Pentane/ EtOAc = 8:2) (Seebach Stain). ${ }^{1}$ H NMR $\left(400 \mathrm{MHz}, \mathrm{CDCl}_{3}\right) \delta 7.91(\mathrm{~d}, J=7.6 \mathrm{~Hz}, 1 \mathrm{H}, \mathrm{ArH}), 7.70(\mathrm{t}, J=7.5 \mathrm{~Hz}, 1 \mathrm{H}, \mathrm{ArH}), 7.57$ $(\mathrm{t}, J=7.5 \mathrm{~Hz}, 1 \mathrm{H}, \mathrm{ArH}), 7.45(\mathrm{~d}, J=7.7 \mathrm{~Hz}, 1 \mathrm{H}, \mathrm{ArH}), 3.65\left(\mathrm{~m}, 2 \mathrm{H}, \mathrm{CH}_{2} \mathrm{~N}_{3}\right), 1.69\left(\mathrm{~s}, 3 \mathrm{H}, \mathrm{CH}_{3}\right)$. ${ }^{13}$ C NMR $\left(101 \mathrm{MHz}, \mathrm{CDCl}_{3}\right) \delta 169.1,150.8,134.5,129.8,126.1,126.1,121.3,85.8,58.1,23.2$. IR 3055 (w), 2985 (w), 2933 (w), 2105 (s), 1761 (s), 1468 (w), 1288 (m), 1035 (s). HRMS (ESI) calcd for $\mathrm{C}_{10} \mathrm{H}_{9} \mathrm{~N}_{3} \mathrm{NaO}_{2}{ }^{+}[\mathrm{M}+\mathrm{Na}]^{+} 226.0587$; found 226.0588. Melting point : $77{ }^{\circ} \mathrm{C}$.

\section{3-(Azidomethyl)isochroman-1-one (2t)}<smiles>NCC1Cc2ccccc2C(=O)O1</smiles>

Starting from 2-allylbenzoic acid 1t $(32 \mathrm{mg}, 0.20 \mathrm{mmol}, 1.0$ equiv.), ADBX reagent $3 \mathbf{b}$ (92 mg, $0.30 \mathrm{mmol}, 1.5$ equiv) and $\mathrm{Pd}(\mathrm{hfacac})_{2}(2.1 \mathrm{mg}, 4.0 \mu \mathrm{mol}, 0.02$ equiv. $)$, the crude product was purified by column chromatography (Pentane/EtOAc $=9: 1$ to 8/2) to afford $\mathbf{2 t}$ as pale yellow oil (29 mg, 0.14 mmol, $71 \%$ yield). ${ }^{1} \mathbf{H}$ NMR (400 MHz, $\left.\mathrm{CDCl}_{3}\right) \delta 8.12-8.00(\mathrm{~m}, 1 \mathrm{H}, \mathrm{ArH}), 7.51$ $(\mathrm{td}, J=7.5,1.5 \mathrm{~Hz}, 1 \mathrm{H}, \operatorname{Ar} H), 7.35(\mathrm{t}, J=7.6 \mathrm{~Hz}, 1 \mathrm{H}, \operatorname{Ar} H), 7.22(\mathrm{~d}, J=7.5 \mathrm{~Hz}, 1 \mathrm{H}, \operatorname{Ar} H), 4.69$ - $4.53(\mathrm{~m}, 1 \mathrm{H}, \mathrm{CH}), 3.67-3.49\left(\mathrm{~m}, 2 \mathrm{H}, \mathrm{CH}_{2} \mathrm{~N}_{3}\right), 3.12\left(\mathrm{dd}, J=16.3,11.8 \mathrm{~Hz}, 1 \mathrm{H}, \mathrm{ArCH}_{2} \mathrm{CH}\right)$, $2.87\left(\mathrm{dd}, J=16.3,3.2 \mathrm{~Hz}, 1 \mathrm{H}, \mathrm{ArCH}_{2} \mathrm{CH}\right) .{ }^{13} \mathbf{C ~ N M R}\left(101 \mathrm{MHz}, \mathrm{CDCl}_{3}\right) \delta 164.6,138.3,134.3$, 130.6, 128.1, 127.8, 124.7, 76.8, 53.8, 30.5. IR 3614 (s), 3075 (w), 3074 (w), 3038 (w), 3038 (w), $2930(\mathrm{w}), 2929(\mathrm{w}), 2928(\mathrm{w}), 2920(\mathrm{w}), 2104(\mathrm{~m}), 1726(\mathrm{~m}), 1609(\mathrm{w}), 1462(\mathrm{w}), 1362(\mathrm{w})$, $1271(\mathrm{~m}), 1228$ (w), $1126(\mathrm{~m}), 1086(\mathrm{~m}), 1033(\mathrm{w}), 950$ (w), 935 (w), 905 (w). HRMS (ESI) calcd for $\mathrm{C}_{10} \mathrm{H}_{9} \mathrm{~N}_{3} \mathrm{NaO}_{2}{ }^{+}[\mathrm{M}+\mathrm{Na}]^{+}$226.0587; found 226.0591.

\section{3-(Azidomethyl)-3-methylisochroman-1-one (2u)}

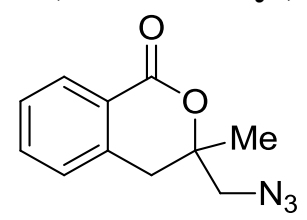

Starting from 2-(2-methylallyl)benzoic acid $1 \mathbf{u}(53 \mathrm{mg}, 0.30 \mathrm{mmol}, 1.0$ equiv.), Pd(hfacac)2 (3 $\mathrm{mg}, 6 \mu \mathrm{mol}, 2 \mathrm{~mol} \%$ ), and ADBX 3b (137 mg, $0.450 \mathrm{mmol}, 1.5$ equiv.) and 20 hours of reaction, the crude product was purified by column chromatography (Pentane/EtOAc $=9: 1$ to $8 / 2$ ) to afford $2 \mathbf{u}$ as pale yellow oil (44 $\mathrm{mg}, 0.20 \mathrm{mmol}, 68 \%$ yield) as a dark yellow viscous oil. Rf: 0.25 (Pentane/EtOAc 7/1). ${ }^{1} \mathbf{H}$ NMR $\left(400 \mathrm{MHz}, \mathrm{CDCl}_{3}\right) \delta 8.09(\mathrm{~d}, J=7.8 \mathrm{~Hz}, 1 \mathrm{H}, \mathrm{ArH}), 7.56$ $(\mathrm{t}, J=7.5 \mathrm{~Hz}, 1 \mathrm{H}, \operatorname{Ar} H), 7.40(\mathrm{t}, J=7.7 \mathrm{~Hz}, 1 \mathrm{H}, \operatorname{Ar} H), 7.25(\mathrm{~d}, J=7.7 \mathrm{~Hz}, 1 \mathrm{H}, \operatorname{Ar} H), 3.54(\mathrm{~d}, J=$ $\left.12.7 \mathrm{~Hz}, 1 \mathrm{H}, \mathrm{ArCH}_{2}\right), 3.40\left(\mathrm{~d}, J=12.7 \mathrm{~Hz}, 1 \mathrm{H}, \mathrm{ArCH}_{2}\right), 3.31\left(\mathrm{~d}, J=16.4 \mathrm{~Hz}, 1 \mathrm{H}, \mathrm{N}_{3} \mathrm{CH}_{2}\right), 2.88$ $\left(\mathrm{d}, J=16.4 \mathrm{~Hz}, 1 \mathrm{H}, \mathrm{N}_{3} \mathrm{CH}_{2}\right), 1.43\left(\mathrm{~d}, J=1.6 \mathrm{~Hz}, 3 \mathrm{H}, \mathrm{CH}_{3}\right) .{ }^{13} \mathbf{C} \mathbf{~ N M R}\left(101 \mathrm{MHz}, \mathrm{CDCl}_{3}\right) \delta$ 163.9, 137.0, 134.2, 130.1, 128.1, 127.7, 124.2, 81.6, 58.1, 34.8, 23.4. IR 3432 (w), $3070(w)$, 2983 (w), 2937 (w), 2108 (s), 1721 (s), 1607 (w), 1459 (w), 1389 (w), 1289 (s), 1236 (m), 1168 (w), $1114(\mathrm{~m}), 1080(\mathrm{~m}), 1036(\mathrm{w}), 950(\mathrm{w}), 841(\mathrm{w})$. HRMS (ESI) calcd for $\mathrm{C}_{11} \mathrm{H}_{11} \mathrm{~N}_{3} \mathrm{NaO}_{2}{ }^{+}$ $[\mathrm{M}+\mathrm{Na}]^{+} 240.0743$; found 240.0748 


\section{3-(Azidomethyl)-3-((benzyloxy)methyl)isochroman-1-one (2v)}<smiles>NCC1(COCc2ccccc2)Cc2ccccc2C(=O)O1</smiles>

Starting from 2-(2-((benzyloxy)methyl)allyl)benzoic acid 1v (85 mg, $0.30 \mathrm{mmol}, 1.0$ equiv.), $\operatorname{Pd}(\text { hfacac })_{2}$ (15.0 mg, $0.029 \mathrm{mmol}, 10 \mathrm{~mol} \%$ ), and ADBX 3b (137 mg, $0.450 \mathrm{mmol}, 1.5$ equiv.) and $20 \mathrm{~h}$ of reaction, the crude product was purified by column chromatography (Pentane/EtOAc $=9: 1$ to $8 / 2$ ) to afford $2 \mathrm{v}$ as pale yellow oil (50.8 mg, $0.141 \mathrm{mmol}, 90 \%$ purity, $45 \%$ yield). A $\geq$ $95 \%$ pure sample was obtained through preparative TLC $(20$ x 20 sqcm plate; pentane/DCM/EtOAc 18/1/1). $\mathrm{Rf}=0.56$ (pentane/EtOAc 5/1) $\left(\mathrm{KMnO}_{4}\right.$ Stain). ${ }^{1} \mathbf{H} \mathbf{~ N M R}(400$ $\left.\mathrm{MHz}, \mathrm{CDCl}_{3}\right) \delta 8.07(\mathrm{dd}, J=7.8,1.3 \mathrm{~Hz}, 1 \mathrm{H}, \mathrm{ArH}), 7.56(\mathrm{td}, J=7.5,1.5 \mathrm{~Hz}, 1 \mathrm{H}, \mathrm{ArH}), 7.39$ (td, $J=7.7,1.2 \mathrm{~Hz}, 1 \mathrm{H}, \mathrm{ArH}), 7.35-7.27(\mathrm{~m}, 3 \mathrm{H}, \mathrm{ArH}+\mathrm{PhH}), 7.25-7.21(\mathrm{~m}, 3 \mathrm{H}, \mathrm{PhH}), 4.56(\mathrm{~d}, J$ $\left.=12.0 \mathrm{~Hz}, 1 \mathrm{H}, \mathrm{PhCH}_{2} \mathrm{O}\right), 4.49\left(\mathrm{~d}, J=12.0 \mathrm{~Hz}, 1 \mathrm{H}, \mathrm{PhCH}_{2} \mathrm{O}\right), 3.63\left(\mathrm{~d}, J=9.7 \mathrm{~Hz}, 1 \mathrm{H}, \mathrm{CCH} \mathrm{H}_{2} \mathrm{O}\right)$, $3.59\left(\mathrm{~d}, J=9.9 \mathrm{~Hz}, 2 \mathrm{H}\right.$, aliphatic $\left.\mathrm{CH}_{2}\right), 3.52\left(\mathrm{~d}, J=9.8 \mathrm{~Hz}, 1 \mathrm{H}, \mathrm{CCH}_{2} \mathrm{O}\right), 3.20(\mathrm{~d}, J=16.7 \mathrm{~Hz}$, $1 \mathrm{H}$, aliphatic $\left.\mathrm{CH}_{2}\right), 3.14\left(\mathrm{~d}, J=16.7 \mathrm{~Hz}, 1 \mathrm{H}\right.$, aliphatic $\left.\mathrm{CH}_{2}\right) \cdot{ }^{13} \mathbf{C} \mathbf{N M R}\left(101 \mathrm{MHz}, \mathrm{CDCl}_{3}\right) \delta$ 163.3, 137.2, 136.6, 134.2, 130.2, 128.4, 128.1, 127.9, 127.7, 127.6, 124.2, 82.6, 73.6, 70.6, 54.8, 30.6. IR 3065 (w), 3035 (w), 2921 (w), 2868 (w), 2105 (s), 1727 (s), 1607 (w), 1488 (w), 1455 (w), 1360 (w), 1283 (s), 1107 (s), 1024 (w), 959 (w), 920 (w), 919 (w). HRMS (ESI) calcd for $\mathrm{C}_{18} \mathrm{H}_{17} \mathrm{~N}_{3} \mathrm{NaO}_{3}^{+}[\mathrm{M}+\mathrm{Na}]^{+}$346.1162; found 346.1161. 


\section{Derivatizations}

\section{4-Oxo-5-phenylpentanoic acid (5)}<smiles>O=C(O)CCC(=O)Cc1ccccc1</smiles>

Dry acetonitrile $(1.5 \mathrm{~mL})$ was added in a flame dried $4 \mathrm{~mL}$ test tube containing a teflon coated stirring bar, the enoic acid $\mathbf{1 a}(53 \mathrm{mg}, 0.30 \mathrm{mmol}, 1.0$ equiv), ADBX reagent $\mathbf{3 b}$ (136 $\mathrm{mg}, 0.450$ mmol, 1.5 equiv) and $\mathrm{Pd}(\mathrm{hfacac})_{2}(3.1 \mathrm{mg}, 6.0 \mu \mathrm{mol}, 0.02$ equiv.). The resulting solution was stirred under $\mathrm{N}_{2}$ at room temperature for $3 \mathrm{~h}$. After completion of the reaction, the crude mixture was obtained after concentration under reduced pressure. Then addition of $18 \mu \mathrm{L}$ of $\mathrm{CH}_{2} \mathrm{Br}_{2}$ as internal standard showed 80-85\% NMR yield. Evaporation of $\mathrm{CDCl}_{3}$ and $\mathrm{CH}_{2} \mathrm{Br}_{2}$ under reduced pressure gave back the crude material, which was directly used without any purification. $\mathrm{Pd} / \mathrm{C}$ (32 mg, $15 \mu \mathrm{mol}, 5 \mathrm{~mol} \%$, loading $5 \%$ in Pd) and EtOAc (1.5 mL, $0.2 \mathrm{M}$ ) were introduced. After bubbling $\mathrm{H}_{2}$ (with balloon) for $5 \mathrm{~min}$, the solution was stirred for $48 \mathrm{~h}$ at $\mathrm{rt}$ under 1 atmosphere of $\mathrm{H}_{2}$. Then the reaction mixture was filtered using HPLC filter to remove solid $\mathrm{Pd} / \mathrm{C}$, before being concentrated under reduced pressure. The crude material was purified by column chromatography, affording 6 (43 mg, $0.22 \mathrm{mmol})$ in $75 \%$ yield over two steps. ${ }^{1} \mathbf{H}$ NMR (400 $\left.\mathrm{MHz}_{\mathrm{CDCl}}\right) \delta 7.36-7.31(\mathrm{~m}, 2 \mathrm{H}, \mathrm{ArH}), 7.30-7.25(\mathrm{~m}, 1 \mathrm{H}, \mathrm{ArH}), 7.21(\mathrm{~m}, 2 \mathrm{H}, \mathrm{ArH}), 3.74(\mathrm{~s}$, $\left.2 \mathrm{H}, \mathrm{ArCH}_{2}\right), 2.75\left(\mathrm{t}, J=6.5 \mathrm{~Hz}, 2 \mathrm{H}, \mathrm{CH}_{2} \mathrm{CH}_{2} \mathrm{CO}_{2} \mathrm{H}\right), 2.61\left(\mathrm{t}, J=6.5 \mathrm{~Hz}, 2 \mathrm{H}, \mathrm{CH}_{2} \mathrm{CH}_{2} \mathrm{CO}_{2} \mathrm{H}\right) .{ }^{13} \mathrm{C}$ NMR $\left(101 \mathrm{MHz}, \mathrm{CDCl}_{3}\right) \delta 206.4,177.9,134.0,129.6,128.9,127.3,50.1,36.3,27.9$. NMR data correspond to the reported values. ${ }^{[30]}$

\section{3-(4-Fluorobenzyl)-3-(4-phenyl-1H-1,2,3-triazol-1-yl)isobenzofuran-1(3H)-one (6)}

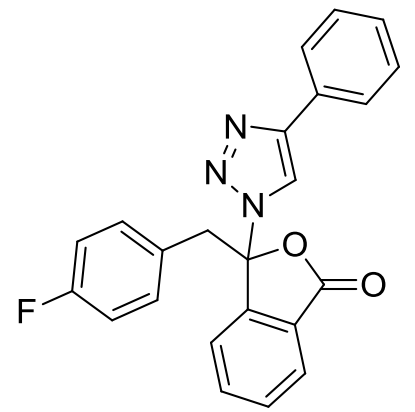

Dry acetonitrile $(1.0 \mathrm{~mL})$ was added in a flame dried $4 \mathrm{~mL}$ test tube containing a teflon coated stirring bar, the enoic acid $\mathbf{1 i}$ (48 $\mathrm{mg}, 0.20 \mathrm{mmol}, 1.0$ equiv), ADBX reagent $\mathbf{3 b}$ (91 $\mathrm{mg}, 0.30$ mmol, 1.5 equiv) and $\mathrm{Pd}(\mathrm{hfacac})_{2}(2.1 \mathrm{mg}, 4.0 \mu \mathrm{mol}, 0.02$ equiv.). The resulting solution was stirred under $\mathrm{N}_{2}$ at room temperature for $2 \mathrm{~h}$. After completion of the reaction, the crude mixture was obtained after concentration under reduced pressure. Then addition of $6 \mu \mathrm{L}$ of $\mathrm{CH}_{2} \mathrm{Br}_{2}$ as internal standard showed 75\% NMR yield. Evaporation of $\mathrm{CDCl}_{3}$ and $\mathrm{CH}_{2} \mathrm{Br}_{2}$ under reduced pressure gave back the crude material which was directly used without any purification. Quantities of triethylamine ( $42 \mu \mathrm{L}, 0.30 \mathrm{mmol}, 2.0$ equiv) and copper iodide $(2.9 \mathrm{mg}, \mu \mathrm{mol}, 0.10$ equiv), ethynylbenzene (33 $\mu \mathrm{l}, 0.30 \mathrm{mmol}, 2.0$ equiv) and THF $(0.75 \mathrm{~mL}, 0.20 \mathrm{M})$ were calculated considering $75 \%$ yield, meaning $0.15 \mathrm{mmol}$ of azidolactone. All the reagents were introduced under nitrogen and the reaction mixture was stirred overnight (16h) at room 
temperature. After completion of the reaction, the resulting mixture was concentrated under reduced pressure and purified by preparative TLC using 60/40 pentane/ethylacetate as eluent system, affording 8 in $65 \%$ isolated yield after two steps. (50 mg, $0.13 \mathrm{mmol}) .{ }^{\mathbf{1}} \mathbf{H}$ NMR (400 $\left.\mathrm{MHz} \mathrm{CDCl}_{3}\right) \delta 7.98(\mathrm{dd}, J=7.7,1.0 \mathrm{~Hz}, 1 \mathrm{H}, \mathrm{Ar} H), 7.81$ (ddd, $J=7.5,4.7,1.1 \mathrm{~Hz}, 2 \mathrm{H}, \operatorname{Ar} H$ ), $7.79-7.72(\mathrm{~m}, 3 \mathrm{H}, \mathrm{ArH}+\mathrm{NCH}), 7.62(\mathrm{td}, J=7.5,0.9 \mathrm{~Hz}, 1 \mathrm{H}, \mathrm{ArH}), 7.44-7.36(\mathrm{~m}, 2 \mathrm{H}, \operatorname{Ar} H)$, $7.36-7.28(\mathrm{~m}, 1 \mathrm{H}, \operatorname{ArH}), 7.01(\mathrm{dd}, J=8.6,5.4 \mathrm{~Hz}, 2 \mathrm{H}, \operatorname{ArH}), 6.84(\mathrm{t}, J=8.6 \mathrm{~Hz}, 2 \mathrm{H}, \operatorname{Ar} H), 4.09$ $\left(\mathrm{d}, J=14.4 \mathrm{~Hz}, 1 \mathrm{H}, \mathrm{ArCH}_{2}\right), 3.88\left(\mathrm{~d}, J=14.3 \mathrm{~Hz}, 1 \mathrm{H}, \operatorname{ArCH}_{2}\right) .{ }^{13} \mathbf{C}$ NMR $\left(100 \mathrm{MHz}, \mathrm{CDCl}_{3}\right)$ $166.5,162.3(\mathrm{~d}, J=247.1 \mathrm{~Hz}), 147.56,146.5,135.3,132.2(\mathrm{~d}, J=8.3 \mathrm{~Hz}), 131.4,129.8,128.8$, $128.5,127.3(\mathrm{~d}, J=3.4 \mathrm{~Hz}), 126.0,125.7,125.0,124.2,117.9,115.3(\mathrm{~d}, J=21.5 \mathrm{~Hz}), 95.8,44.3$.

${ }^{19}$ F NMR (376 MHz, CDCl $)_{3} \delta-114.07$ (m, 1F). IR $3145(w), 3065(w), 2885(w), 2253(w)$, 2148 (w), 1894 (w), 1789 (s), 1607 (w), 1512 (m), 1475 (w), 1464 (w), 1415 (m), 1353 (w), 1279 (m), 1228 (m), 1160 (w), 1075 (m), 1029 (w), 971 (s), 915 (m), 840 (m). HRMS (ESI) calcd for $\mathrm{C}_{23} \mathrm{H}_{16} \mathrm{FN}_{3} \mathrm{NaO}_{2}{ }^{+}[\mathrm{M}+\mathrm{Na}]^{+}$408.1119; found 408.1111. Melting point: $141.7-148.5{ }^{\circ} \mathrm{C}$ (decomp.).

\section{Methyl 4-oxo-5-phenylpentanoate (7)<smiles>COC(=O)CCC(=O)Cc1ccccc1</smiles>

Dry acetonitrile $(1.5 \mathrm{~mL})$ was added in a flame dried $4 \mathrm{~mL}$ test tube containing a teflon coated stirring bar, the enoic acid $\mathbf{1 a}(53 \mathrm{mg}, 0.30 \mathrm{mmol}, 1.0$ equiv), ADBX reagent $\mathbf{3 b}$ (136 $\mathrm{mg}, 0.450$ mmol, 1.5 equiv) and $\mathrm{Pd}(\mathrm{hfacac})_{2}(3.1 \mathrm{mg}, 6.0 \mu \mathrm{mol}, 0.02$ equiv.). The resulting solution was stirred under $\mathrm{N}_{2}$ at room temperature for $3 \mathrm{~h}$. After completion of the reaction, the crude mixture was obtained after concentration under reduced pressure. Then addition of $18 \mu \mathrm{L}$ of $\mathrm{CH}_{2} \mathrm{Br}_{2}$ as internal standard showed 80-85\% NMR yield. Evaporation of $\mathrm{CDCl}_{3}$ and $\mathrm{CH}_{2} \mathrm{Br}_{2}$ under reduced pressure gave back the crude material, which was directly used without any purification. $\mathrm{Pd} / \mathrm{C}$ (16 mg, $7.5 \mu \mathrm{mol}, 2.5 \mathrm{~mol} \%$, loading $5 \%$ in $\mathrm{Pd}$ ) and Methanol $(1.5 \mathrm{~mL}, 0.2 \mathrm{M}$ ) were introduced. After bubbling $\mathrm{H}_{2}$ (with balloon) for $5 \mathrm{~min}$, the solution was stirred for $24 \mathrm{~h}$ at $\mathrm{rt}$ under 1 atmosphere of $\mathrm{H}_{2}$. Full conversion was confirmed by TLC (90/10 pentane/ethylacetate), then the reaction mixture was filtered using HPLC filter to remove solid $\mathrm{Pd} / \mathrm{C}$. The vial was rinsed 3 times using EtOAc before being concentrated under reduced pressure and purified by preparative column chromatography over silicagel, using 90/10 pentane/ethylacetate as eluent system, affording $\mathbf{8}$ as a pale yellow oil in $70 \%$ isolated yield after two steps. (43 mg, $0.21 \mathrm{mmol}){ }^{\mathbf{1}} \mathbf{H}$ NMR $\left(400 \mathrm{MHz}, \mathrm{CDCl}_{3}\right) \delta 7.37-7.30(\mathrm{~m}, 2 \mathrm{H}, \mathrm{ArH}), 7.30-7.16(\mathrm{~m}, 3 \mathrm{H}, \mathrm{ArH}), 3.74(\mathrm{~s}, 2 \mathrm{H}$, $\mathrm{CH}_{2} \mathrm{Ar}$ ), 3.65 (s, 3H, Me), $2.76\left(\mathrm{t}, \mathrm{J}=6.6 \mathrm{~Hz}, 2 \mathrm{H}, \mathrm{CH}_{2} \mathrm{CH}_{2} \mathrm{COOMe}\right), 2.56$ (t, J = 6.6 Hz, 2H, $\left.\mathrm{CH}_{2} \mathrm{CH}_{2} \mathrm{COOMe}\right) .{ }^{13} \mathrm{C}$ NMR $\left(101 \mathrm{MHz}, \mathrm{CDCl}_{3}\right) \delta 206.4,173.1,134.0,129.4,128.7,127.0,51.7$, 50.0, 36.4, 27.7. NMR data correspond to the reported values. ${ }^{[21]}$

\section{4-((tert-Butoxycarbonyl)amino)-5-(4-chlorophenyl)pentanoic acid (8)}

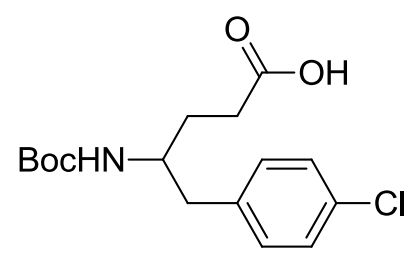


In a flame dried $4 \mathrm{~mL}$ test-tube were introduced azido lactone $4 \mathbf{d}(25 \mathrm{mg}, 0.10 \mathrm{mmol})$ and THF $(1.0 \mathrm{~mL}, 0.10 \mathrm{M})$ under nitrogen. To this solution was added black platinum $(2.0 \mathrm{mg}, 10 \mathrm{mmol}$, 0.10 equiv) and $\mathrm{Boc}_{2} \mathrm{O}$ (44 mg, $0.20 \mathrm{mmol}, 2.0$ equiv.), before being placed under $\mathrm{H}_{2}$ pressure (1atm, balloon). The resulting solution was stirred for $18 \mathrm{~h}$ at room temperature. Filtration using HPLC filter and evaporation of the solvent under reduced pressure gave the crude mixture as a solid-oil mixture. Final precipitation was obtained by adding chloroform. After two washing sequence with chloroform, the expected product 9 was isolated as colorless solid $(16 \mathrm{mg}, 0.048$ mmol, $48 \%$ yield). NB: Mixture of rotamers not fully resolved (M stands for major rotamer, $\mathrm{m}$ stands for minor rotamer). (NMR ratio: 86:14). ${ }^{1} \mathbf{H}$ NMR $\left(400 \mathrm{MHz}, \mathrm{DMSO}-d_{6}\right) \delta 12.01(\mathrm{~s}, 1 \mathrm{H}$, $\mathrm{COOH}(\mathrm{M}+\mathrm{m})), 7.38(\mathrm{~d}, J=8.4 \mathrm{~Hz}, 0.13 \mathrm{H}, \operatorname{Ar} H(\mathrm{~m})), 7.32(\mathrm{~d}, J=8.3 \mathrm{~Hz}, 1.87 \mathrm{H}, \operatorname{Ar} H(\mathrm{M}))$, $7.23-7.15(\mathrm{~d}, J=8.3 \mathrm{~Hz}, 2 \mathrm{H}, \operatorname{Ar} H(\mathrm{M}+\mathrm{m})), 6.72(\mathrm{~d}, J=8.9 \mathrm{~Hz}, 0.86 \mathrm{H}, \mathrm{NH}(\mathrm{M})), 6.31(\mathrm{~d}, J=$ $9.2 \mathrm{~Hz}, 0.14 \mathrm{H}, \mathrm{NH}(\mathrm{m})), 3.66-3.49(\mathrm{~m}, 1 \mathrm{H}, \mathrm{NCH}(\mathrm{M}+\mathrm{m})), 2.65\left(\mathrm{~m}, 2 \mathrm{H}, \mathrm{ArCH}_{2}(\mathrm{M}+\mathrm{m})\right), 2.30-$ $2.13\left(\mathrm{~m}, 2 \mathrm{H}, \mathrm{CH}_{2} \mathrm{CH}_{2} \mathrm{COOH}(\mathrm{M}+\mathrm{m})\right), 1.67\left(\mathrm{~m}, 1 \mathrm{H}, \mathrm{CH}_{2} \mathrm{CH}_{2} \mathrm{COOH}(\mathrm{M}+\mathrm{m})\right), 1.52(\mathrm{~m}, 1 \mathrm{H}$, $\left.\mathrm{CH}_{2} \mathrm{CH}_{2} \mathrm{COOH}(\mathrm{M}+\mathrm{m})\right), 1.32(\mathrm{~s}, 7.5 \mathrm{H}, \mathrm{Boc}(\mathrm{M})), 1.23$ (s, $1.5 \mathrm{H}$, Boc $\left.(\mathrm{m})\right) .{ }^{13} \mathrm{C}$ NMR $(100 \mathrm{MHz}$, DMSO- $d_{6}$ ) (only major rotamer) $\delta 174.2,155.2,138.1,131.0,130.5,127.9,77.3,51.0,40.1$, 30.4, 29.5, 28.2. IR 3359 (w), 2975 (m), 2934 (m), 2605 (w), 2260 (w), 2118 (w), 1902 (w), 1695 (s), $1521(\mathrm{~m}), 1448(\mathrm{w}), 1402(\mathrm{~m}), 1363(\mathrm{~m}), 1257$ (m), 1170 (s), 1093 (w), 1024 (s), 900 (w), 818 (w). HRMS (ESI) calcd for $\mathrm{C}_{16} \mathrm{H}_{21} \mathrm{ClNO}_{4}{ }^{-}[\mathrm{M}-\mathrm{H}]^{-}$326.1165; found 326.1156; Melting point: $146.9-147.9^{\circ} \mathrm{C}$.

\section{3-Amino-3-(4-fluorobenzyl)isobenzofuran-1(3H)-one (9)}

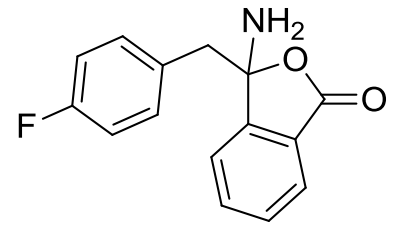

In a flame dried $4 \mathrm{~mL}$ test-tube were introduced unseparated iodoalcohol and azido lactone $4 \mathbf{k}$ (51 mg, $0.18 \mathrm{mmol}$, based on NMR yield) and THF $(1.8 \mathrm{~mL}, 0.10 \mathrm{M})$ under nitrogen. To this solution was added black platinum ( $3.5 \mathrm{mg}, 18 \mu \mathrm{mol}, 0.10$ equiv) and $\mathrm{Boc}_{2} \mathrm{O}$ (79 mg, $0.36 \mathrm{mmol}$, 2.0 equiv), before being placed under $\mathrm{H}_{2}$ pressure (1 atm, balloon). The resulting solution was stirred for $15 \mathrm{~h}$ at room temperature. Filtration using HPLC filter and evaporation of the solvent under reduced pressure gave the crude mixture. Purification using preparative TLC using 55/45 pentane/ethyl acetate as eluant afforded primary amine product $\mathbf{1 0}$ as colorless solid (37 $\mathrm{mg}, 0.14$ mmol, $80 \%$ yield). No N-Boc protected amine was observed. The reaction was scaled up to 420 $\mathrm{mg}$ of azidolactone $\mathbf{4 k}(1.48 \mathrm{mmol})$ dissolved in $14 \mathrm{~mL}$ of THF and using only black platinum catalyst (29 mg, $0.15 \mathrm{mmol}, 0.10$ equiv). In this case, $80 \%$ conversion and $53 \%$ yield of 9 was obtained $(203 \mathrm{mg}, 0.789 \mathrm{mmol}) .{ }^{1} \mathbf{H}$ NMR $\left(400 \mathrm{MHz}, \mathrm{CDCl}_{3}\right) \delta 7.76(\mathrm{~d}, J=7.1 \mathrm{~Hz}, 1 \mathrm{H}, \operatorname{Ar} H)$, $7.67(\mathrm{td}, J=7.3,1.1 \mathrm{~Hz}, 1 \mathrm{H}, \operatorname{Ar} H), 7.52(\mathrm{t}, J=7.3 \mathrm{~Hz}, 2 \mathrm{H}, \operatorname{Ar} H), 7.20-7.12\left(\mathrm{~m}, 2 \mathrm{H}, \operatorname{Ar}_{\mathrm{F}} H\right)$, $6.97-6.87$ (m (app tt), 2H, $\left.\operatorname{Ar}_{\mathrm{F}} H\right), 3.26\left(\mathrm{~s}, 2 \mathrm{H}, \mathrm{Ar}_{\mathrm{F}} \mathrm{CH}_{2}\right), 2.52$ (brs, 2H, NH $\left.\mathrm{N}_{2}\right){ }^{13} \mathbf{C} \mathbf{N M R}(100$ $\left.\mathrm{MHz}, \mathrm{CDCl}_{3}\right) \delta 168.5,162.2(\mathrm{~d}, J=246.0 \mathrm{~Hz}), 149.3,134.0,132.3(\mathrm{~d}, J=8.0 \mathrm{~Hz}), 130.2,129.6$ $(\mathrm{d}, J=3.3 \mathrm{~Hz}), 127.7,125.3,122.8,115.1(\mathrm{~d}, J=21.3 \mathrm{~Hz}), 98.7,45.9 .{ }^{19} \mathbf{F}$ NMR $(376 \mathrm{MHz}$, $\mathrm{CDCl}_{3}$ ) $\delta$-115.15 (m, 1F). IR 3403 (w), 3337 (w), 3235 (w), 3059 (w), $2927(\mathrm{w}), 2857$ (w), 2254 (w), 1751 (s), 1611 (w), $1511(\mathrm{~m}), 1475$ (w), 1429 (w), 1383 (w), $1284(\mathrm{~m}), 1229$ (m), $1156(\mathrm{w})$, 1120 (m), 1088 (w), 1010 (w), 942 (w), 867 (m), 838 (w). HRMS (ESI) calcd for $\mathrm{C}_{15} \mathrm{H}_{12} \mathrm{FNNaO}_{2}{ }^{+}[\mathrm{M}+\mathrm{Na}]^{+} 280.0744$; found 280.0741 . Melting point: $132.7-135.7{ }^{\circ} \mathrm{C}$ (decomp.). 


\section{Spectra of compounds}

a. Spectra of new compounds of starting materials

${ }^{1} \mathbf{H}$ NMR (400 MHz, $\mathrm{CDCl}_{3}$ ) of compound 4-(2,5-dimethylphenyl)pent-4-enoic acid (11)

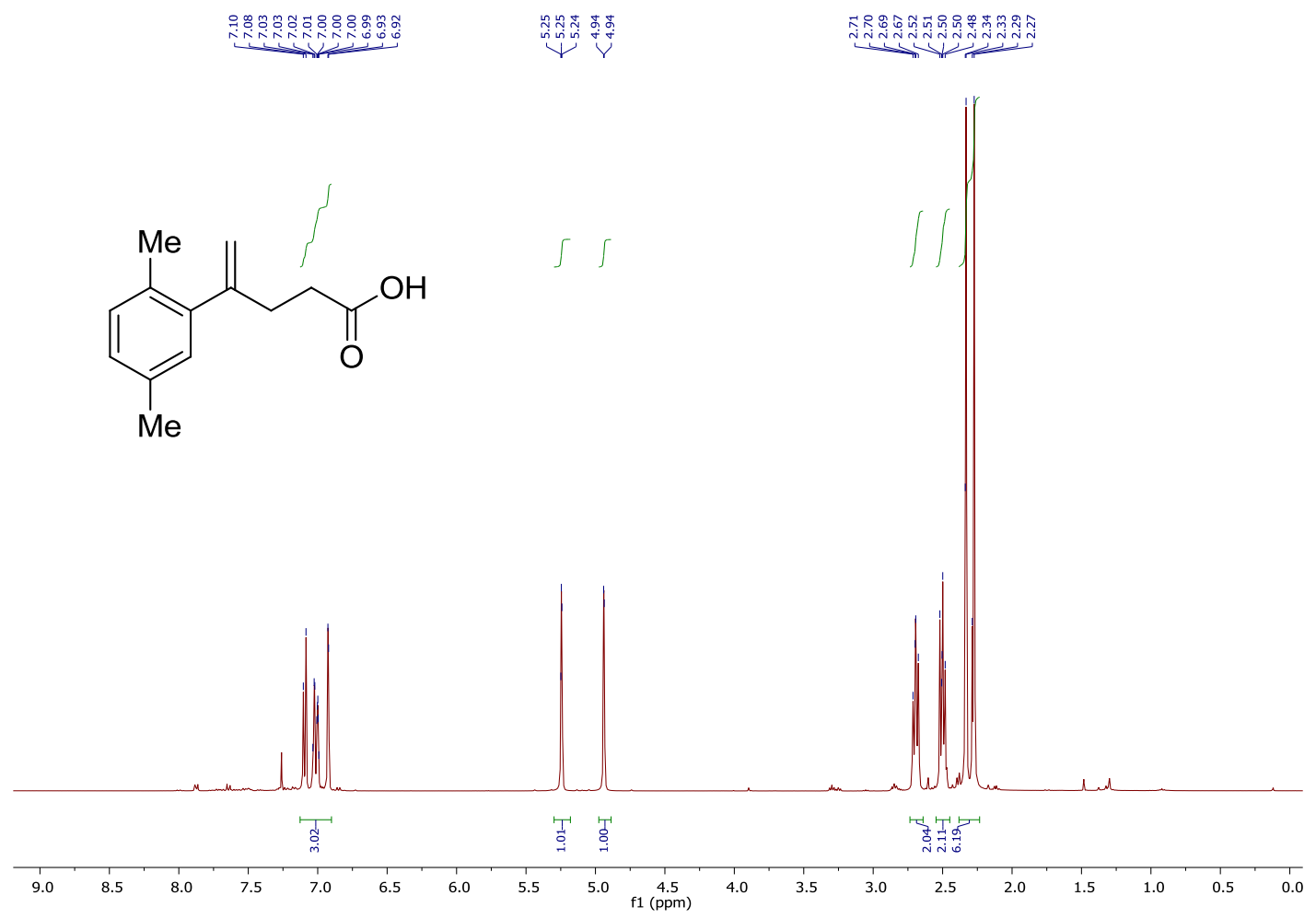


${ }^{13} \mathrm{C}$ NMR (101 MHz, $\mathrm{CDCl}_{3}$ ) of compound 4-(2,5-dimethylphenyl)pent-4-enoic acid (11)

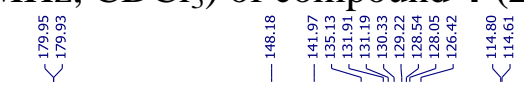

许

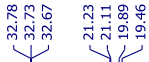
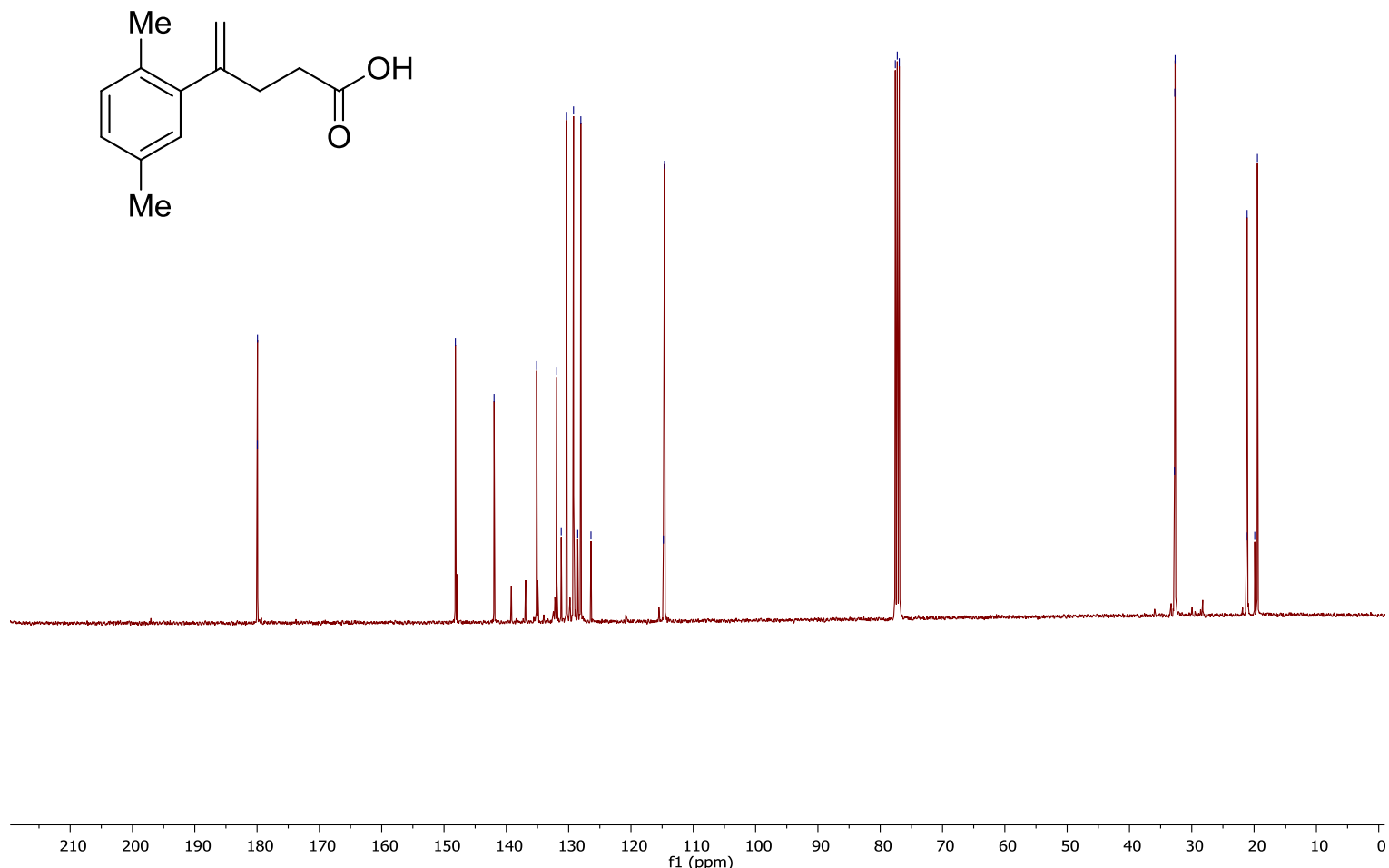

IR of compound 4-(2,5-dimethylphenyl)pent-4-enoic acid (11)

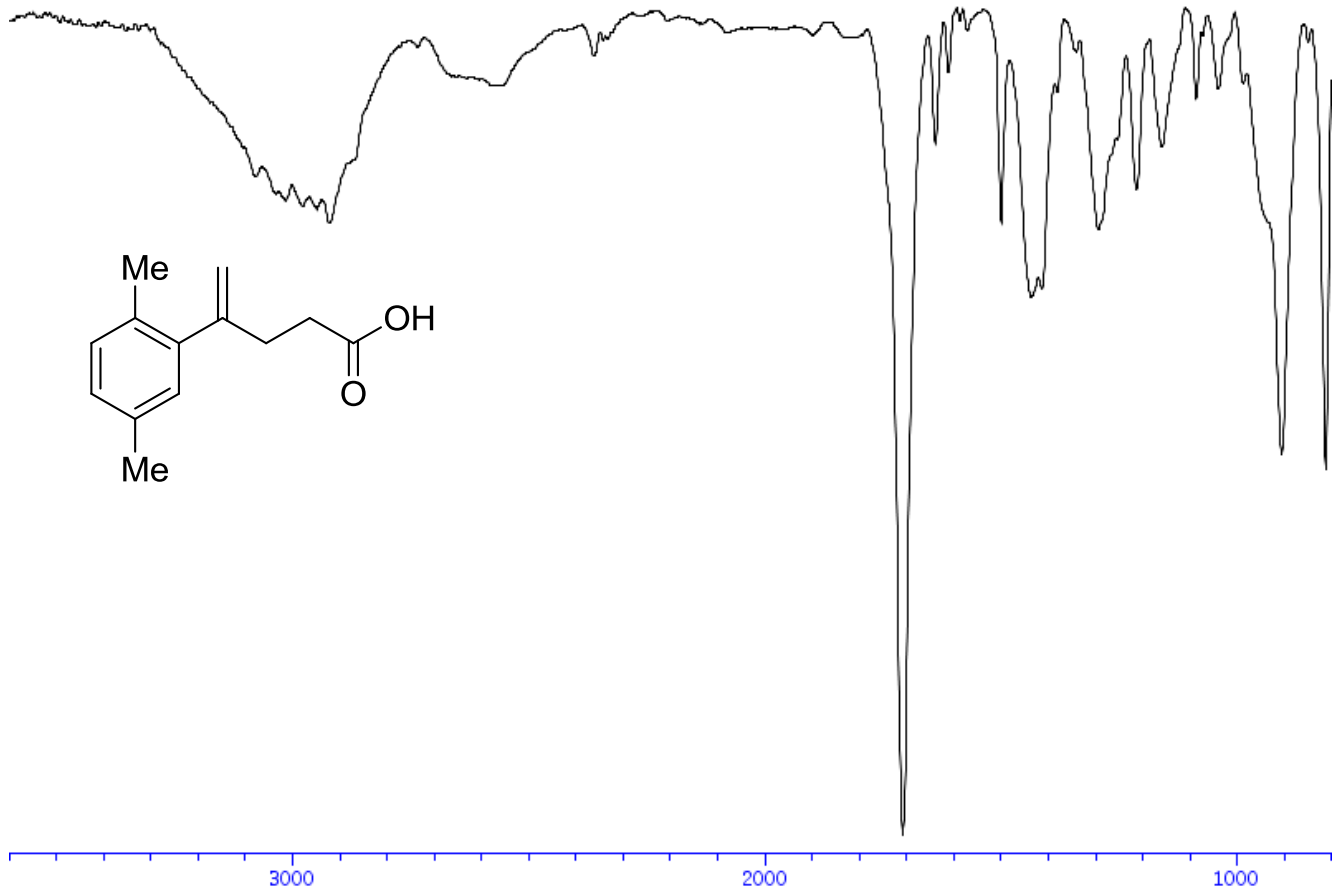


${ }^{1}$ H NMR (400 MHz, $\mathrm{CDCl}_{3}$ ) of compound 2-(1-methylene-2,3-dihydro-1H-inden-2-yl)acetic acid (1m)

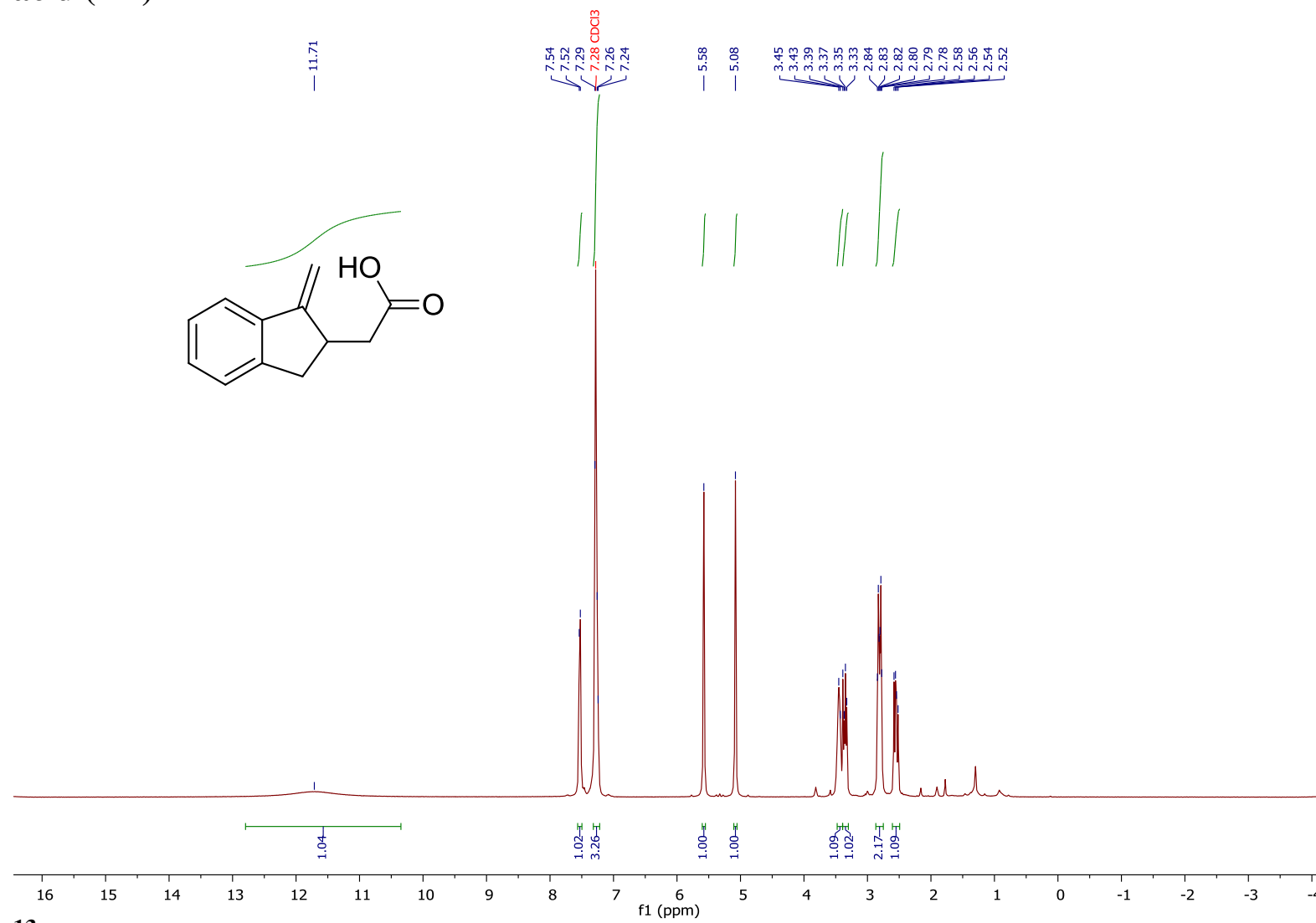

${ }^{13} \mathrm{C}$ NMR $\left(101 \mathrm{MHz}, \mathrm{CDCl}_{3}\right)$ of compound 2-(1-methylene-2,3-dihydro-1H-inden-2-yl)acetic acid (1m)

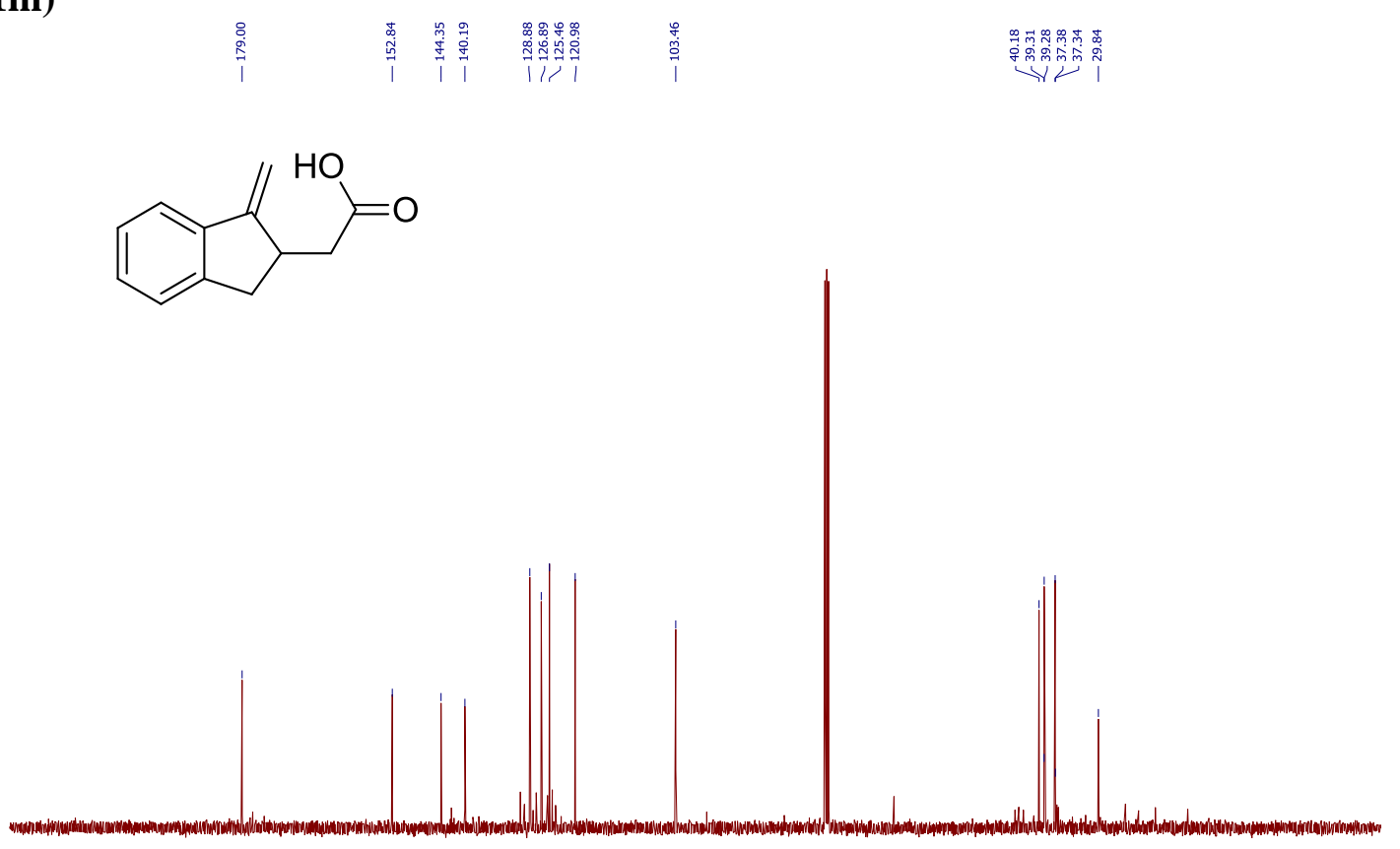

$\begin{array}{lllllllllllllllllllllll}210 & 200 & 190 & 180 & 170 & 160 & 150 & 140 & 130 & 120 & 110 & 100 & 90 & 80 & 70 & 60 & 50 & 40 & 30 & 20 & 10 & 0 & -10\end{array}$ 
IR of compound 2-(1-methylene-2,3-dihydro-1H-inden-2-yl)acetic acid (1m)

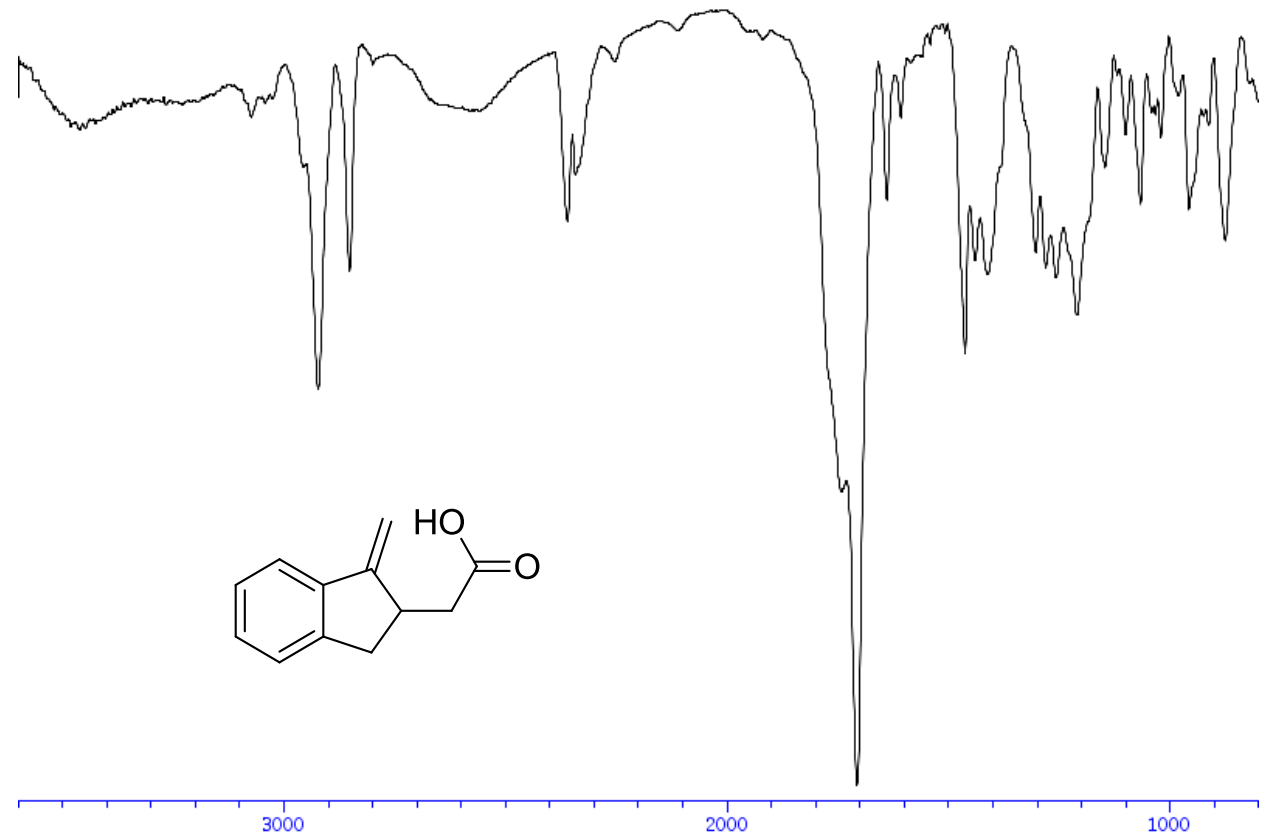

${ }^{\mathbf{1}} \mathbf{H}$-NMR (400 MHz, $\left.\left(\mathrm{CD}_{3}\right)_{2} \mathrm{CO}\right)$ of compound 4-methylene-7-phenylheptanoic acid (1s)

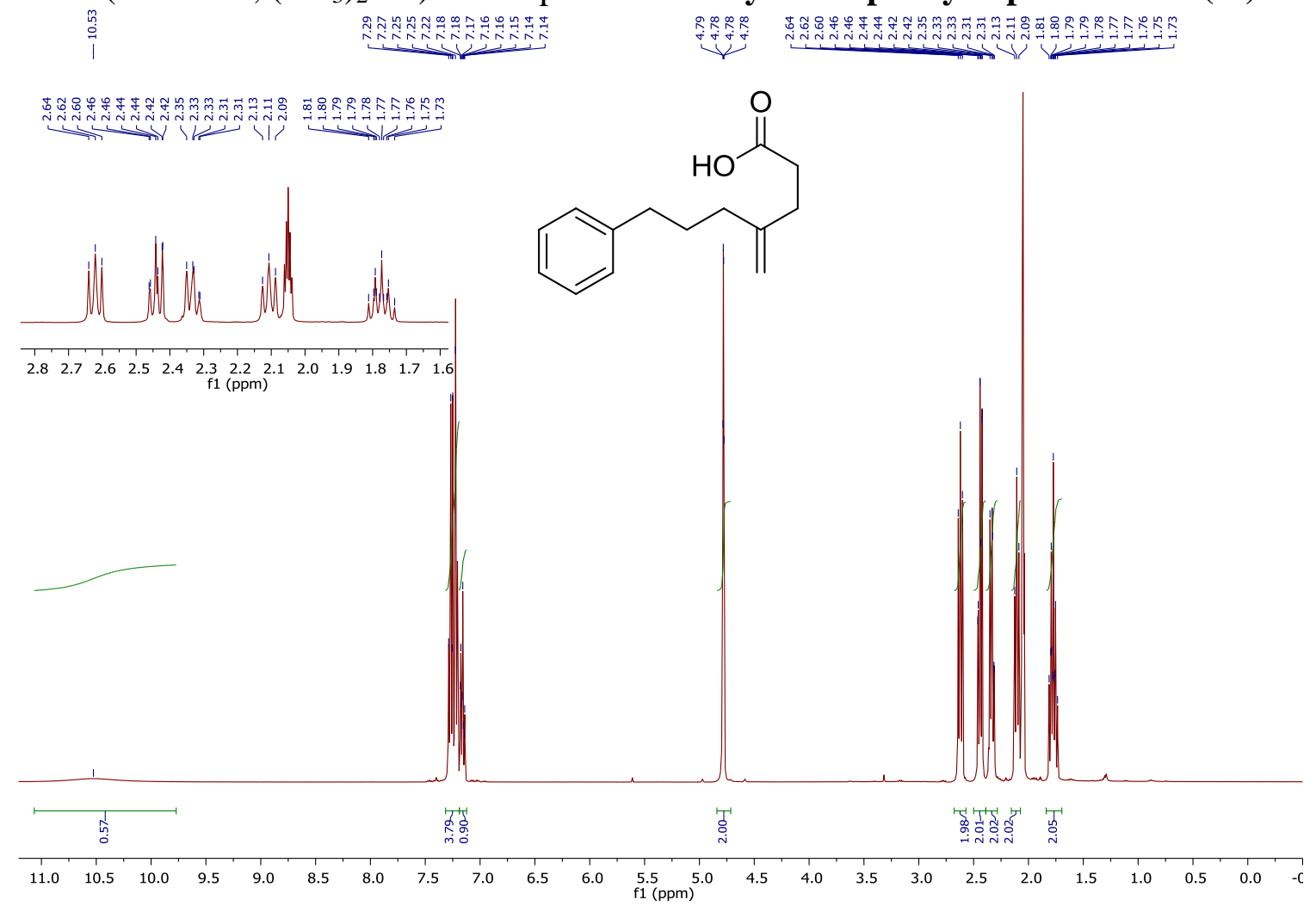



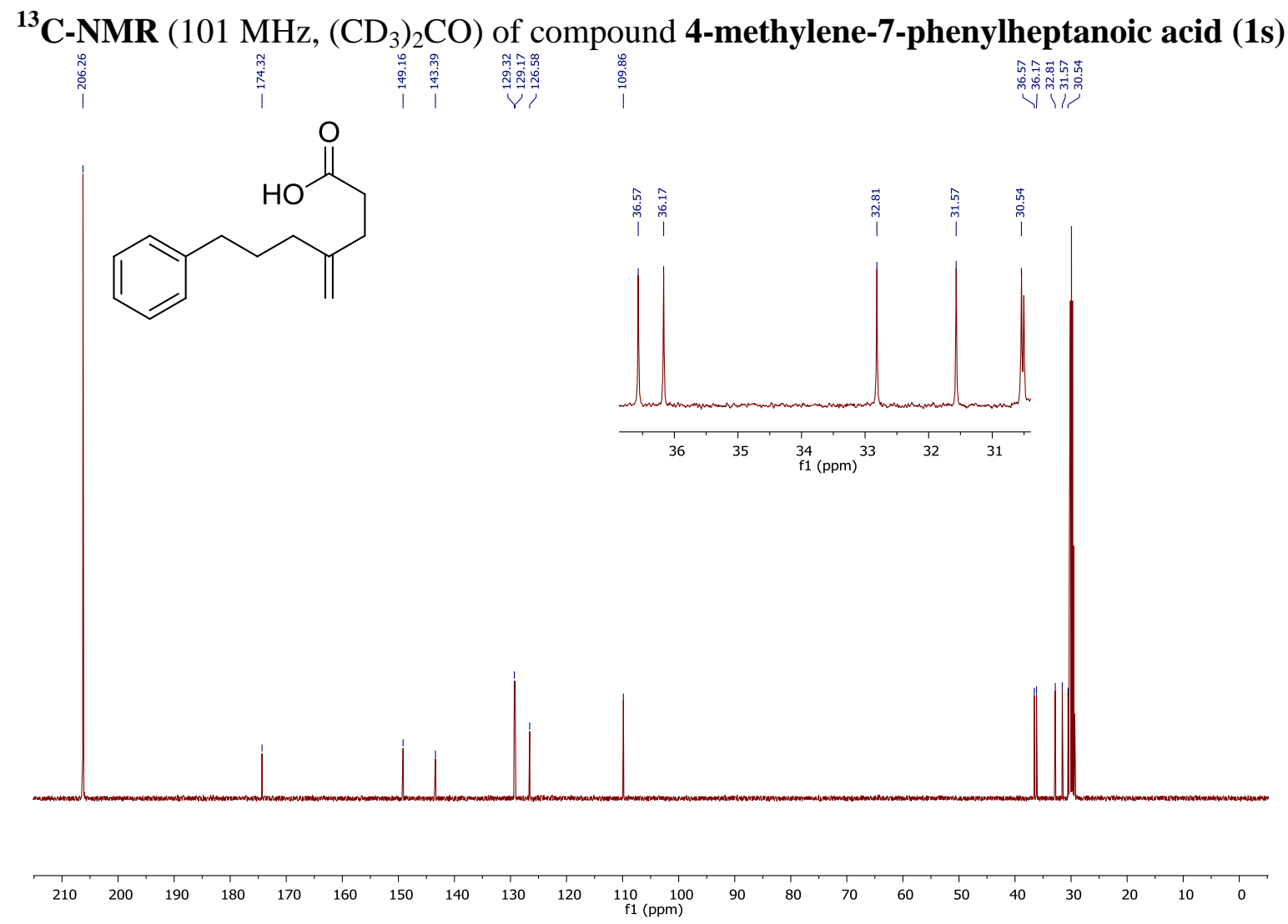

IR of compound 4-methylene-7-phenylheptanoic acid (1s)

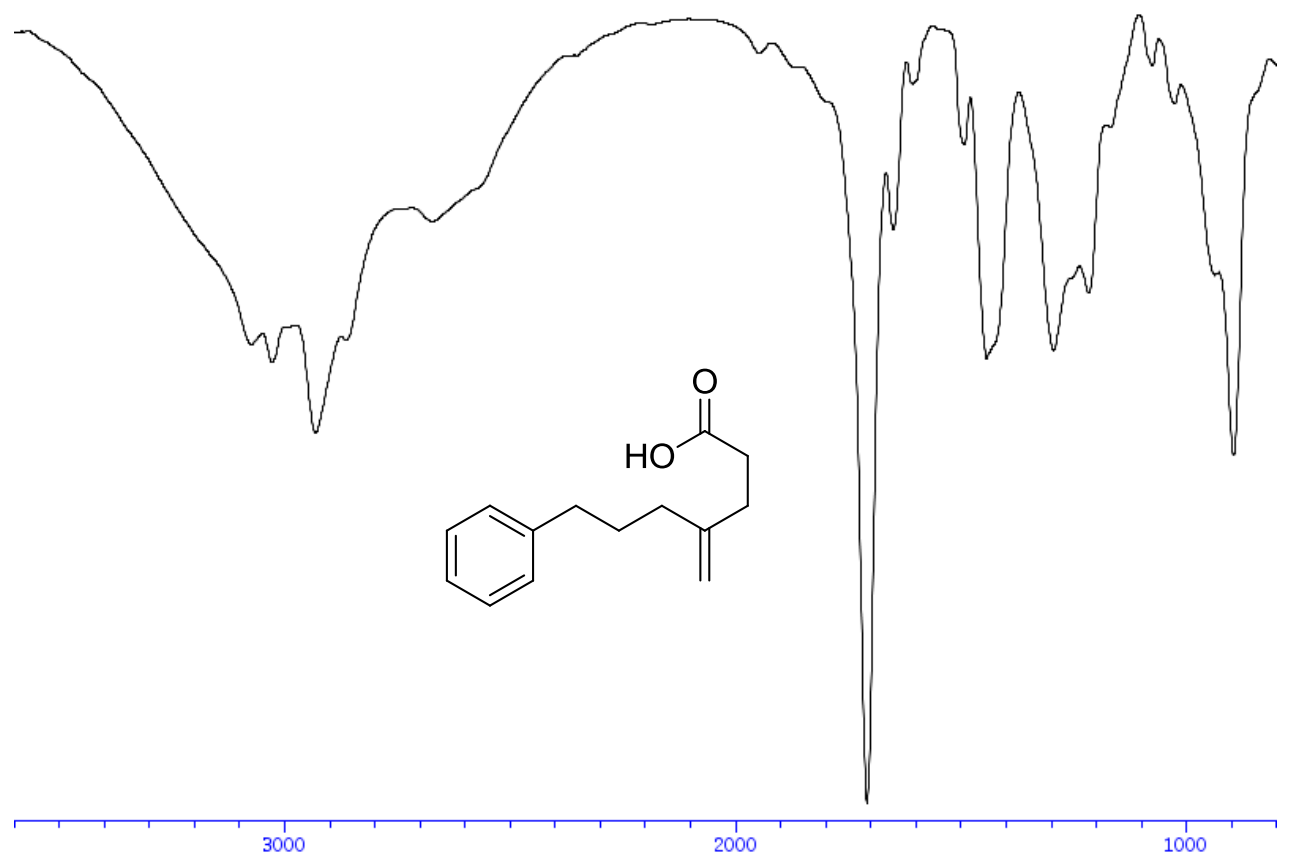


${ }^{\mathbf{1}} \mathbf{H}-\mathrm{NMR}\left(400 \mathrm{MHz}, \mathrm{CDCl}_{3}\right)$ of compound 2-(2-((Benzyloxy)methyl)allyl)benzoic acid (1v)

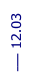

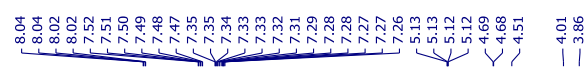<smiles>C=C(COc1ccccc1)Cc1ccccc1C(=O)O</smiles>

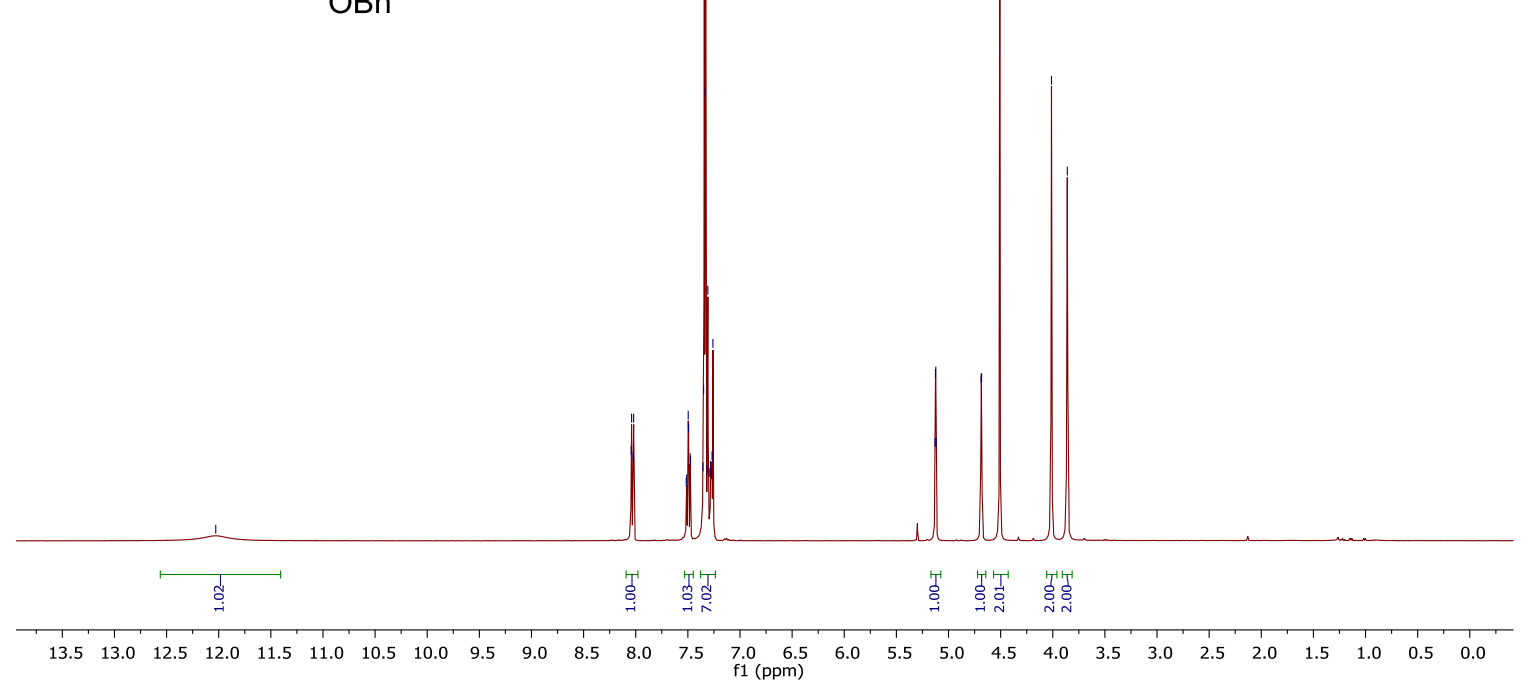

${ }^{13} \mathbf{C}$-NMR (101 MHz, $\left.\mathrm{CDCl}_{3}\right)$ of compound 2-(2-((Benzyloxy)methyl)allyl)benzoic acid (1v)
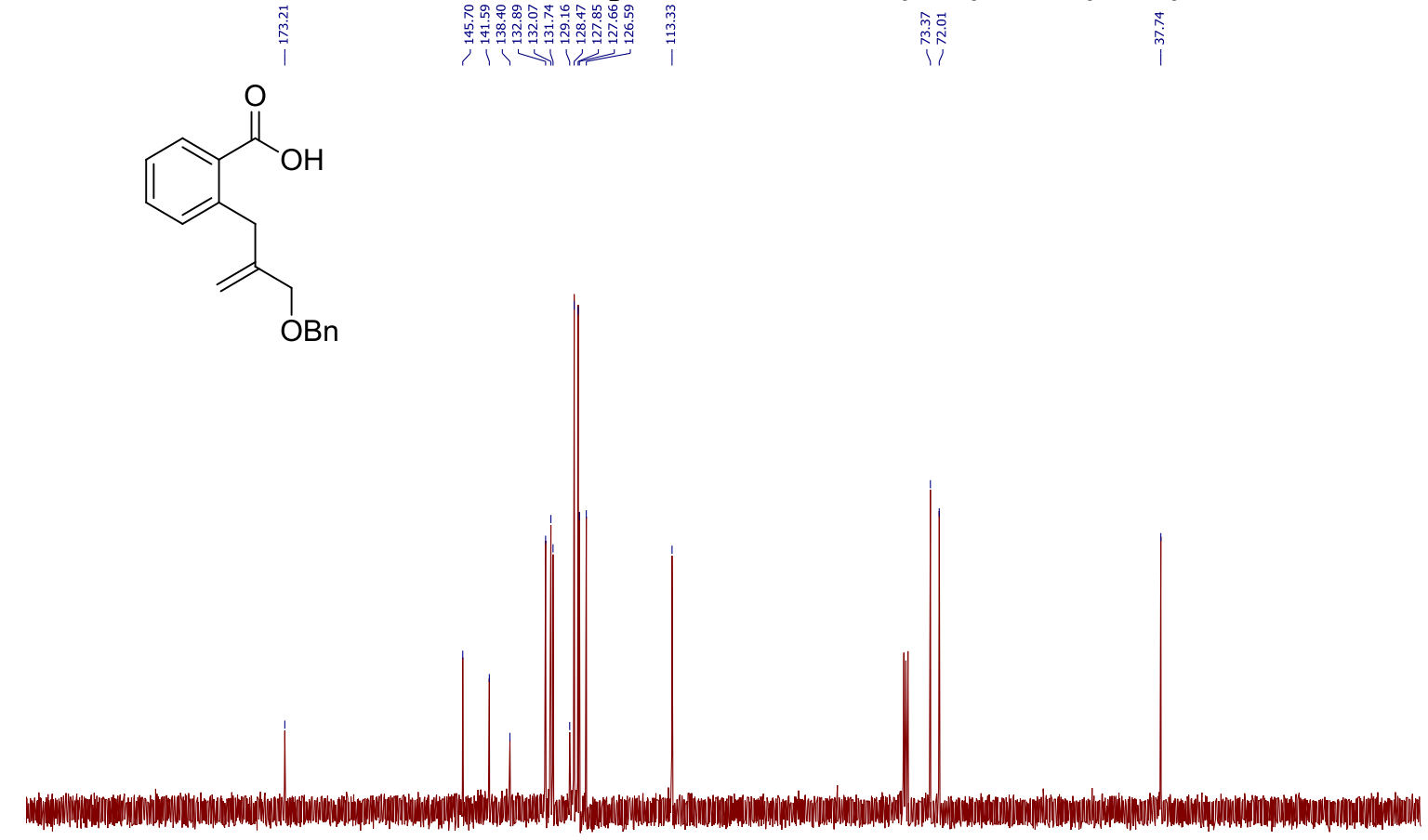

210

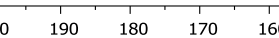

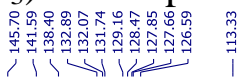


IR of compound 2-(2-((Benzyloxy)methyl)allyl)benzoic acid (1v)

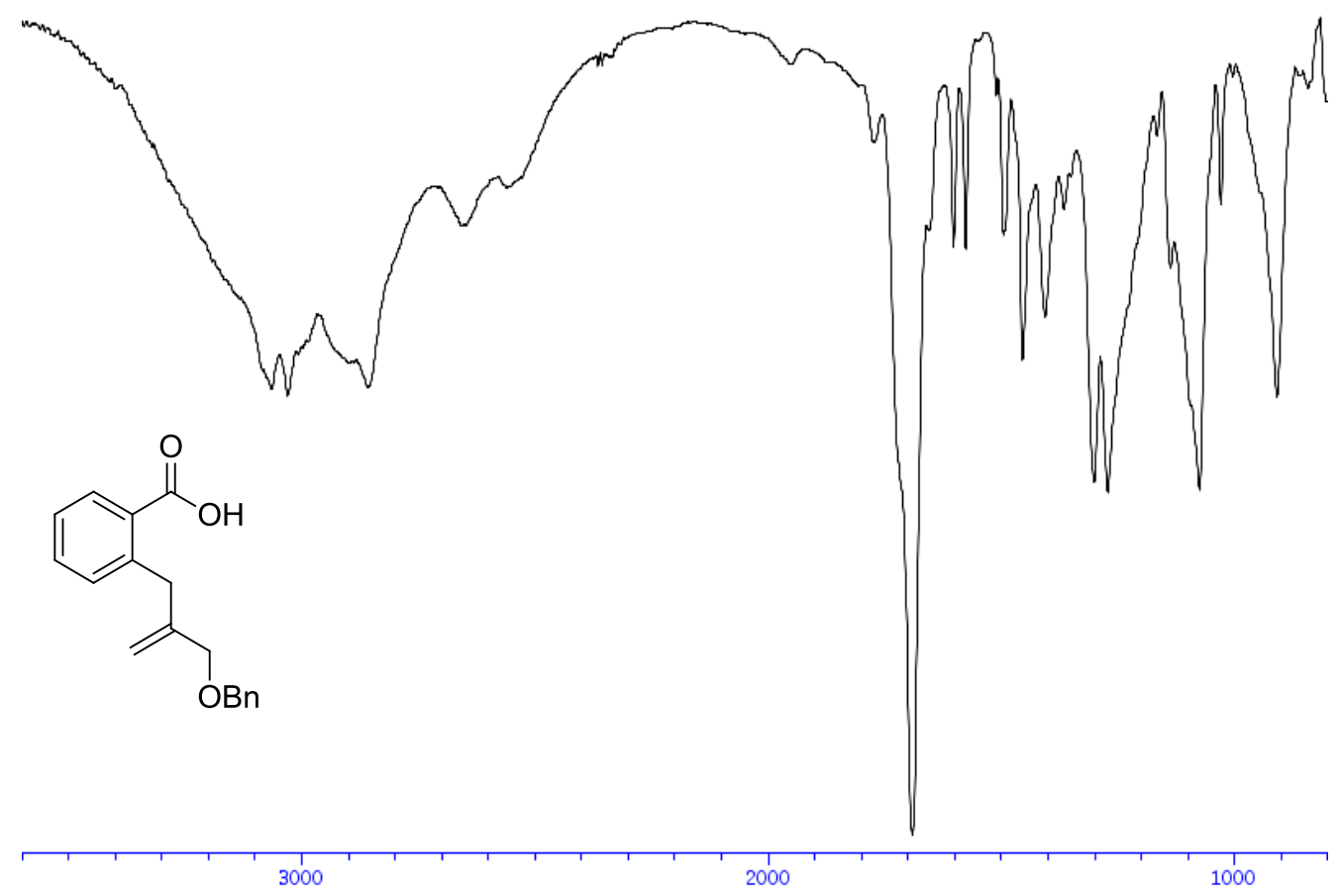




\section{b. Spectra of compounds from photoredox catalysis}

${ }^{\mathbf{1}} \mathbf{H}$ NMR (400 MHz, $\mathrm{CDCl}_{3}$ ) of compound 5-(azidomethyl)-5-phenyldihydrofuran-2(3H)-one (2a)

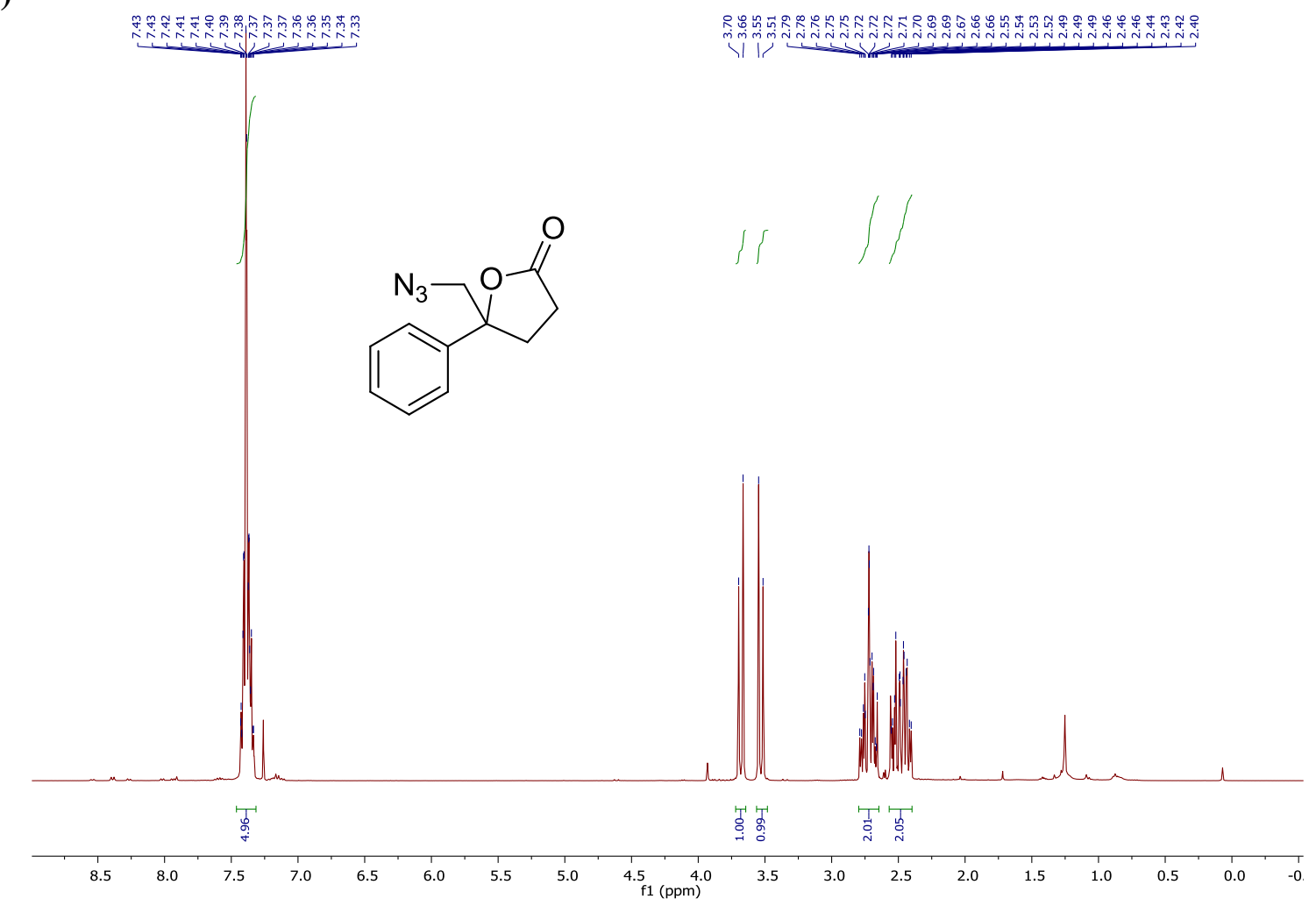

${ }^{13} \mathrm{C}$ NMR (101 $\mathrm{MHz}, \mathrm{CDCl}_{3}$ ) of compound 5-(azidomethyl)-5-phenyldihydrofuran-2(3H)one (2a)

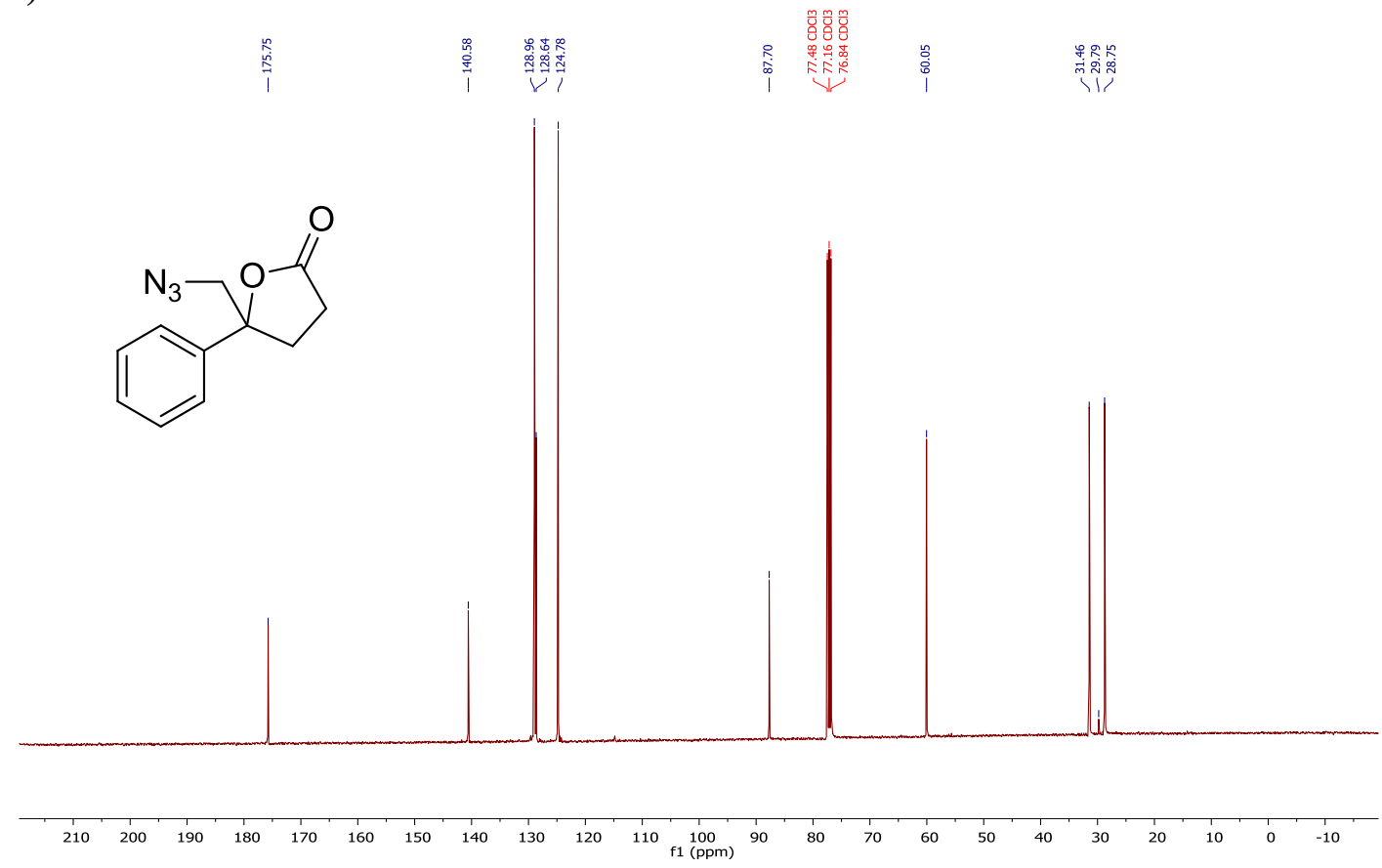


${ }^{\mathbf{1}} \mathbf{H}$ NMR (400 MHz, $\mathrm{CDCl}_{3}$ ) of compound 5-(azidomethyl)-5-(p-tolyl)dihydrofuran-2(3H)-one (2b)

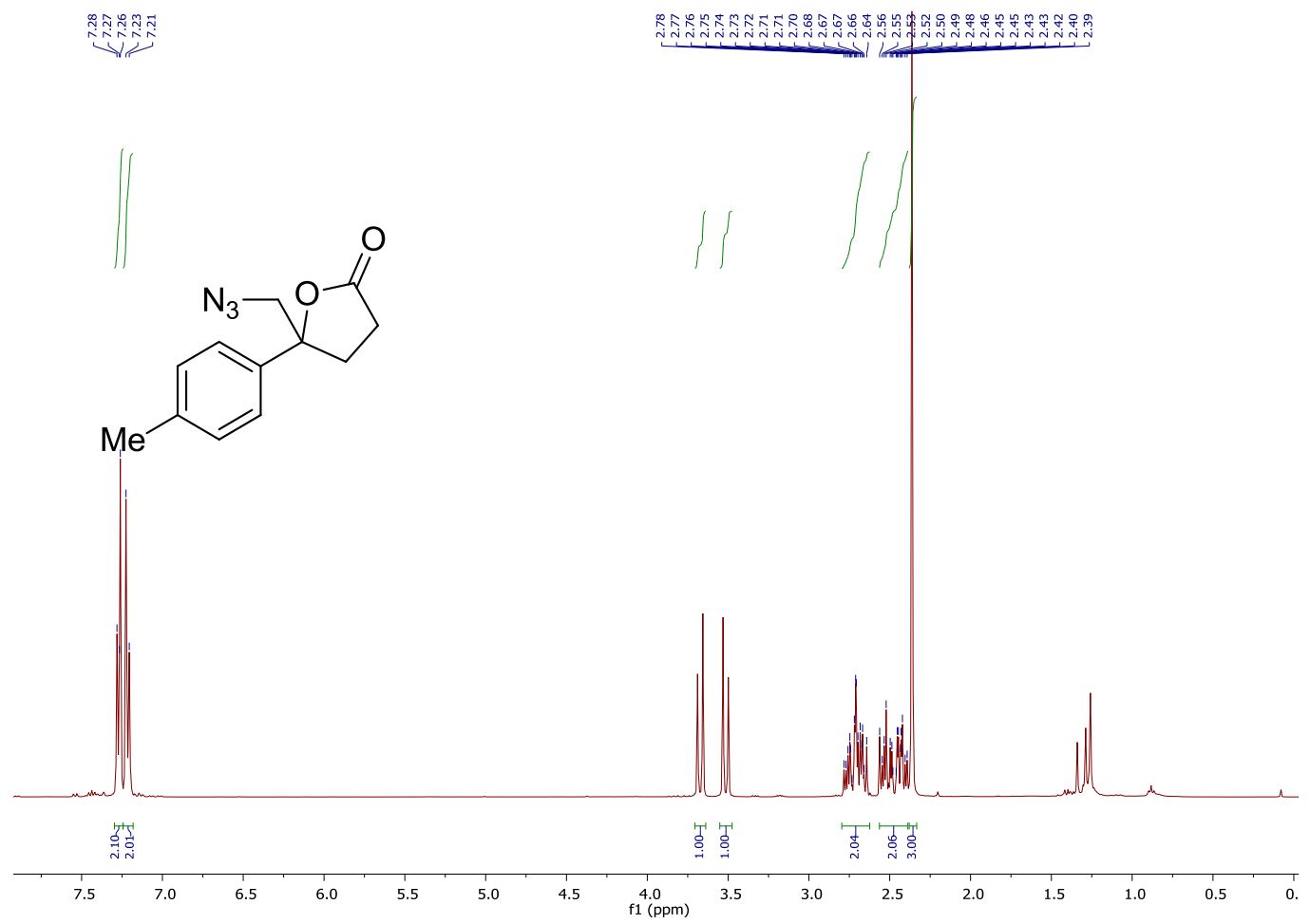

${ }^{13} \mathbf{C}$ NMR (101 MHz, $\left.\mathrm{CDCl}_{3}\right)$ of compound 5-(azidomethyl)-5-(p-tolyl)dihydrofuran-2(3H)one (2b)

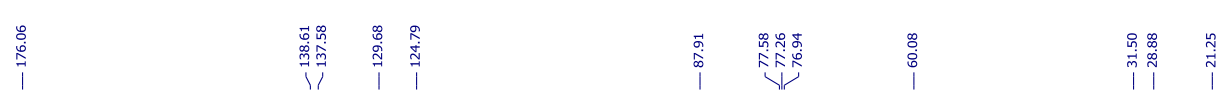
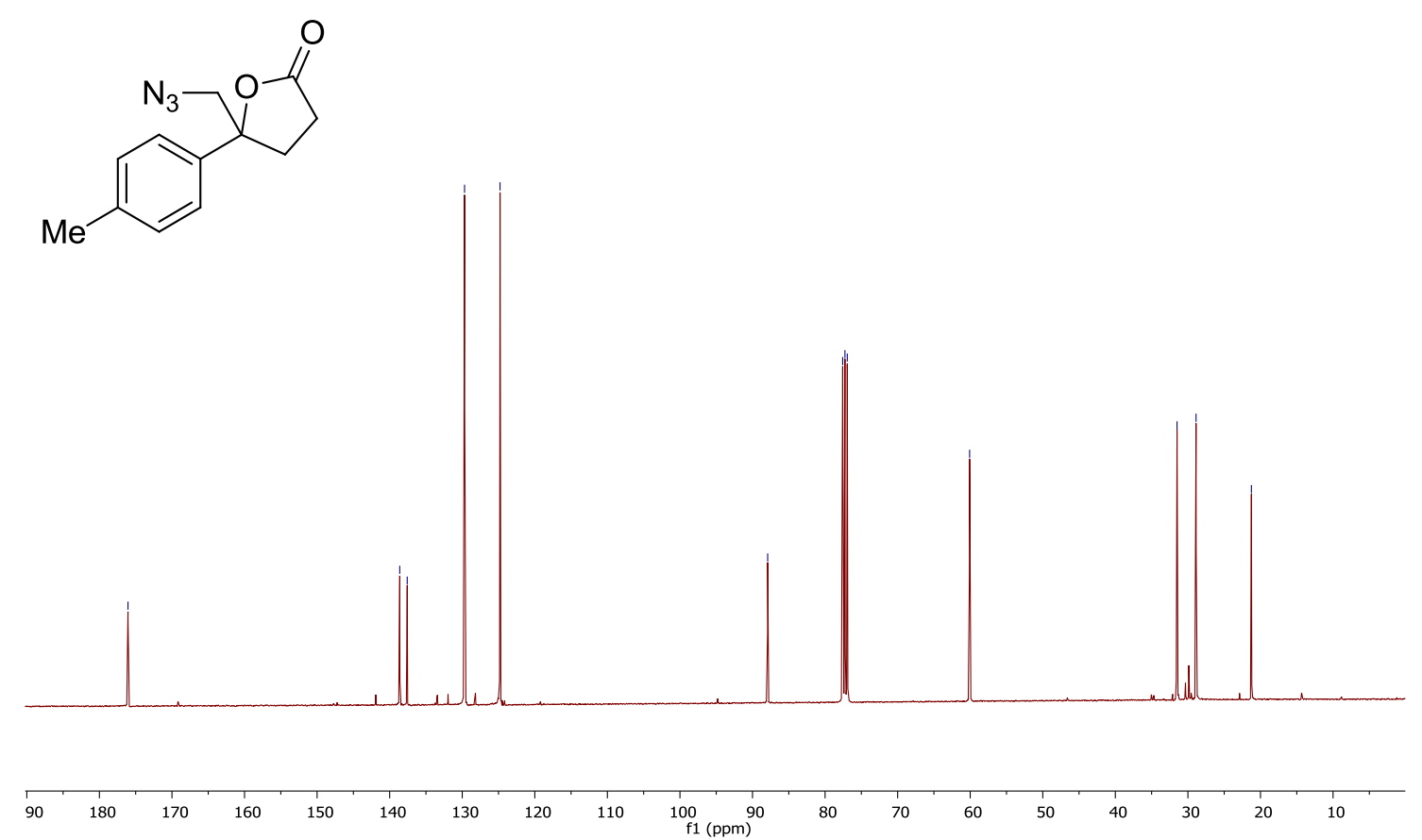
IR of compound 5-(azidomethyl)-5-(p-tolyl)dihydrofuran-2(3H)-one (2b)

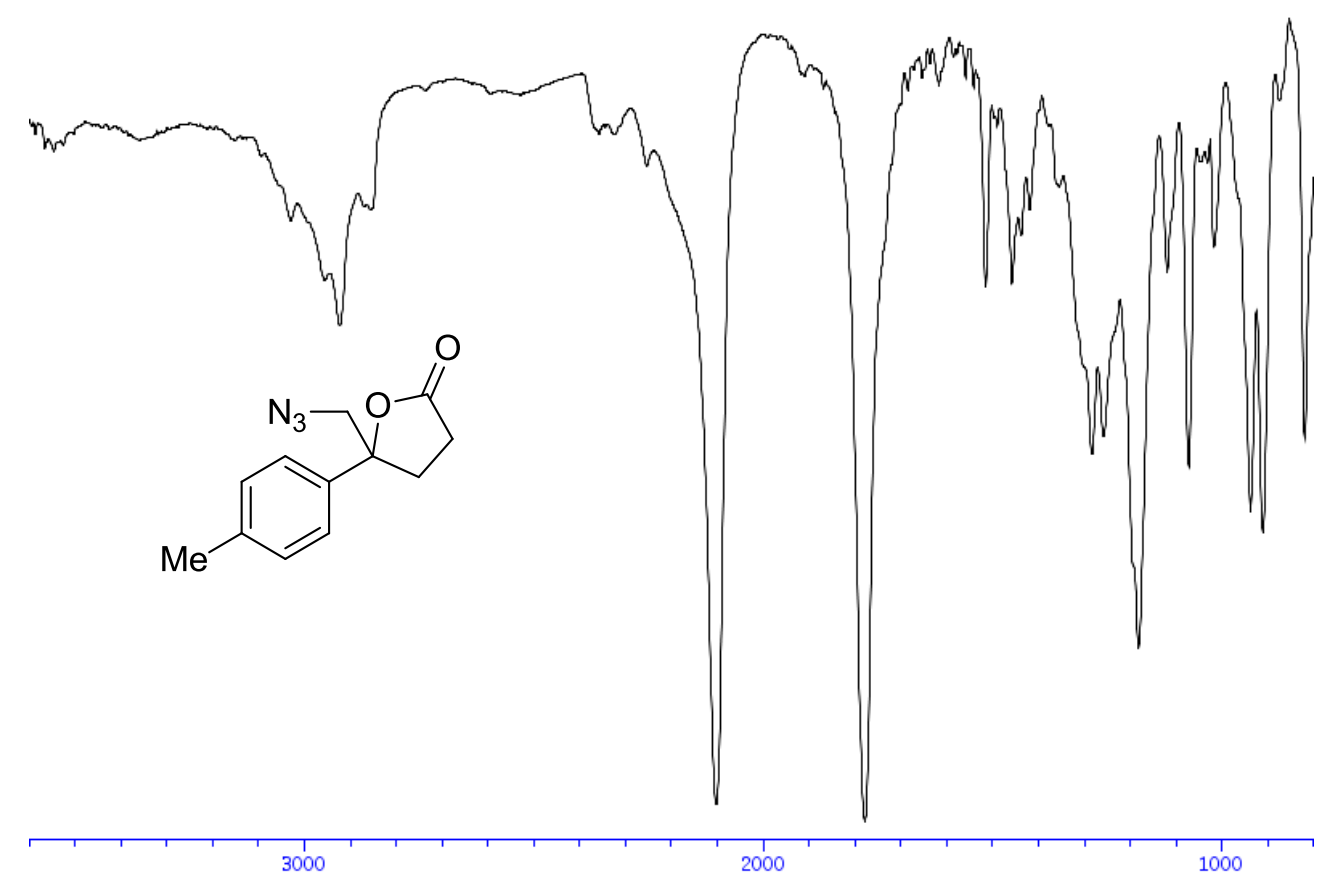

${ }^{\mathbf{1}} \mathbf{H}$ NMR (400 MHz, $\mathrm{CDCl}_{3}$ ) of compound 5-(azidomethyl)-5-(4methoxyphenyl)dihydrofuran-2(3H)-one (2c)

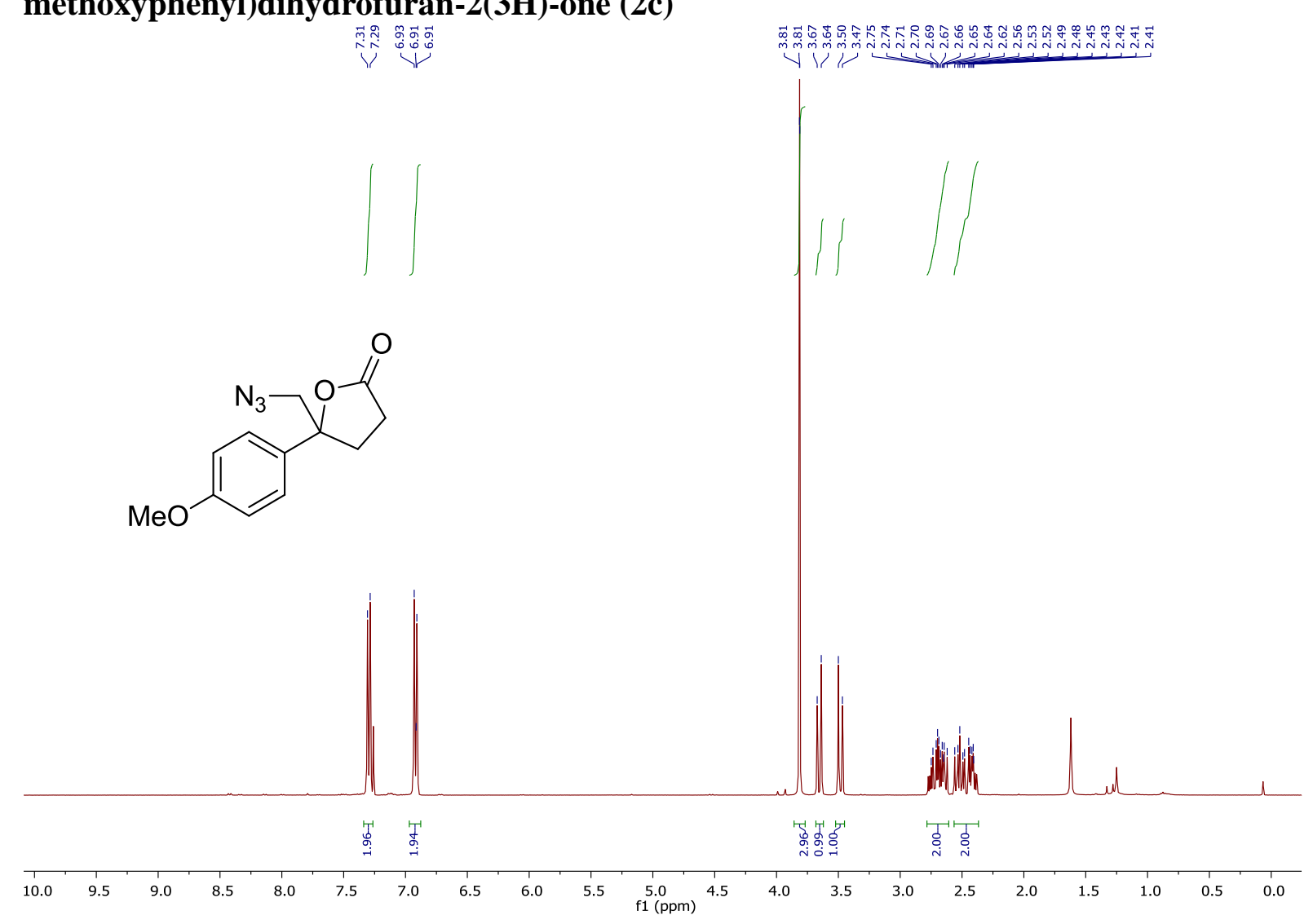


${ }^{13}$ C NMR (101 MHz, $\mathrm{CDCl}_{3}$ ) of compound 5-(azidomethyl)-5-(4methoxyphenyl)dihydrofuran-2(3H)-one (2c)

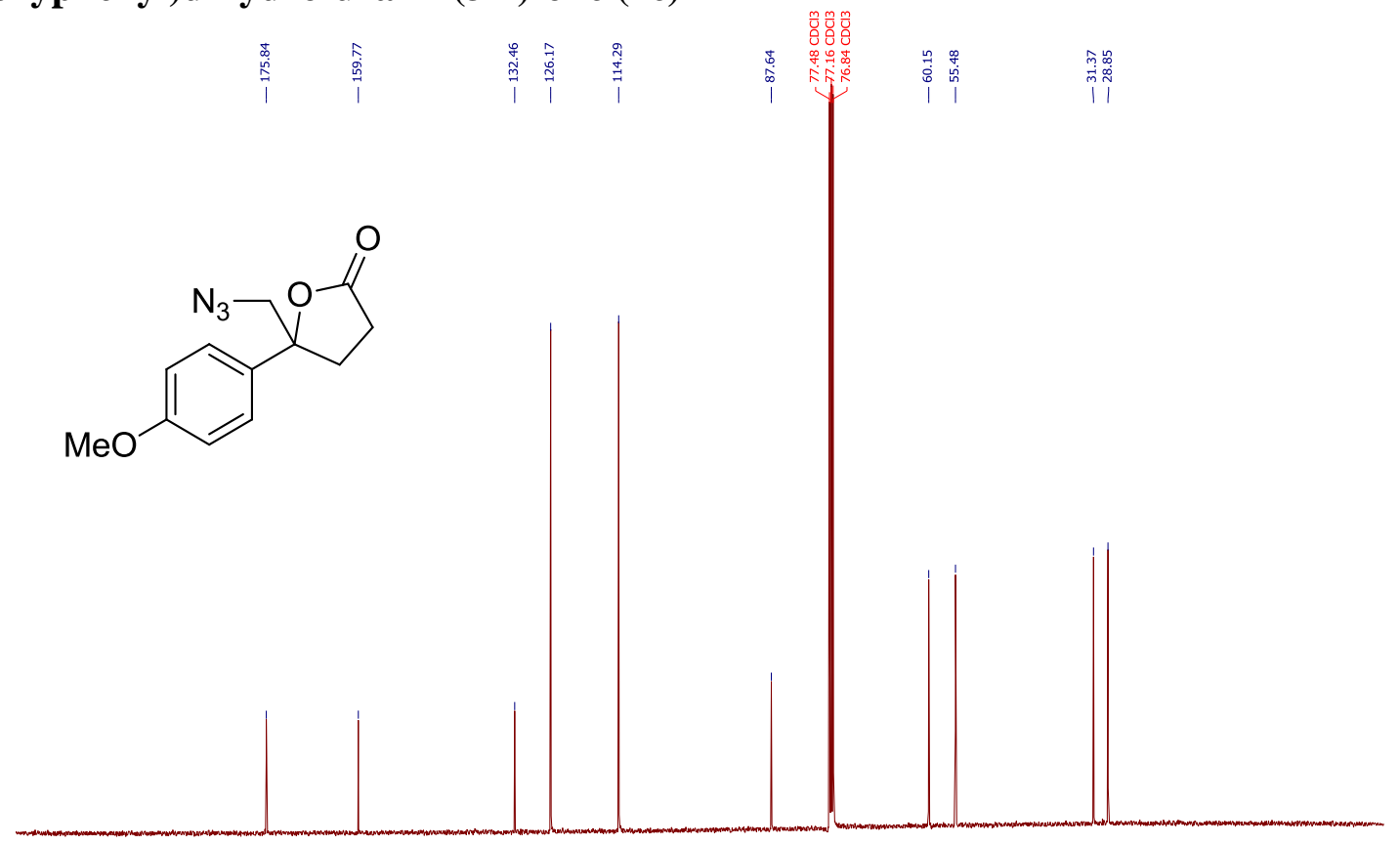

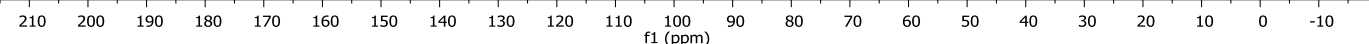

${ }^{\mathbf{1}} \mathbf{H}$ NMR (400 MHz, $\mathrm{CDCl}_{3}$ ) of compound 5-(azidomethyl)-5-(4-bromophenyl)dihydrofuran2(3H)-one (2d)

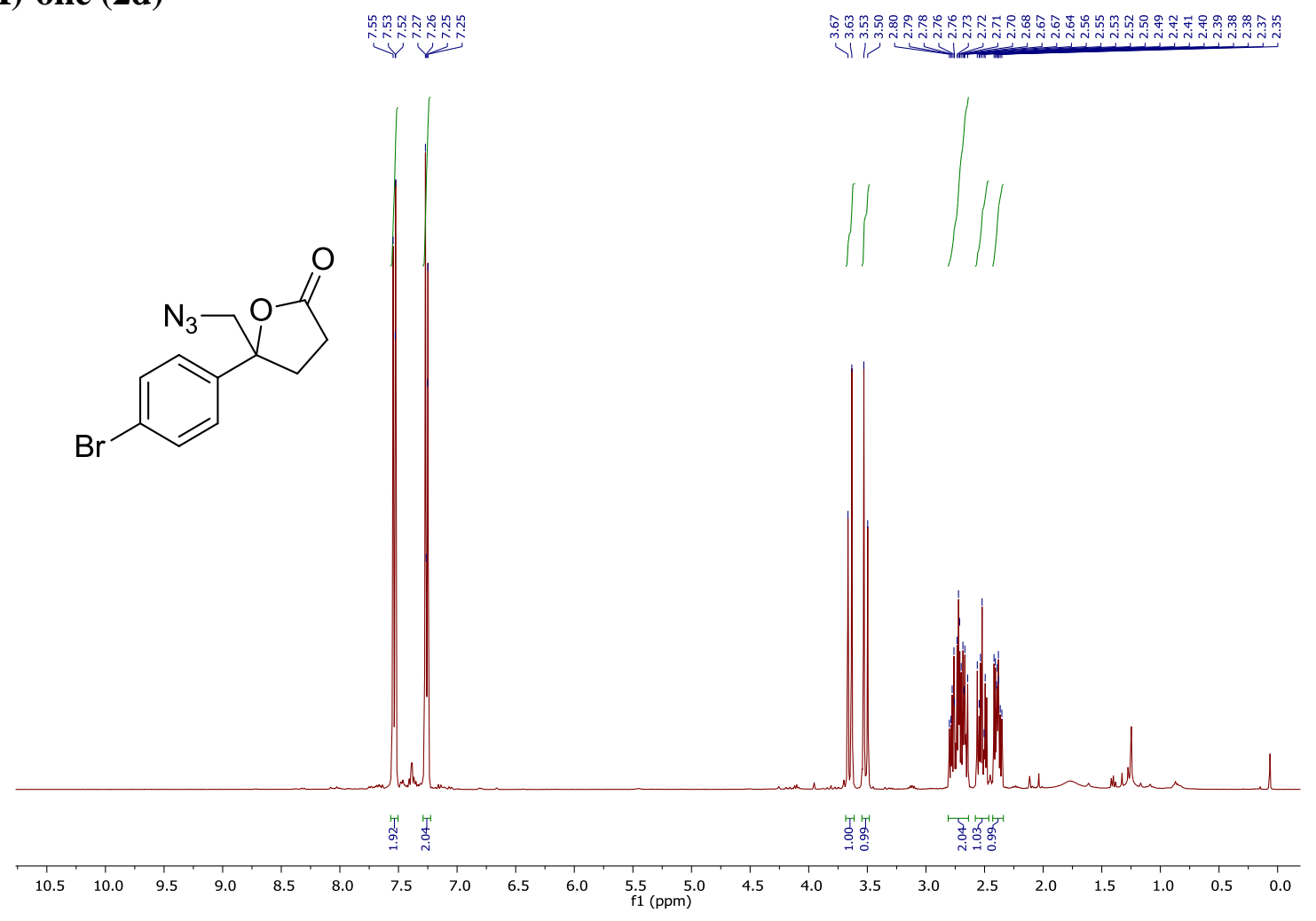


${ }^{13} \mathrm{C}$ NMR (101 MHz, $\mathrm{CDCl}_{3}$ ) of compound 5-(azidomethyl)-5-(4-bromophenyl)dihydrofuran2(3H)-one (2d)
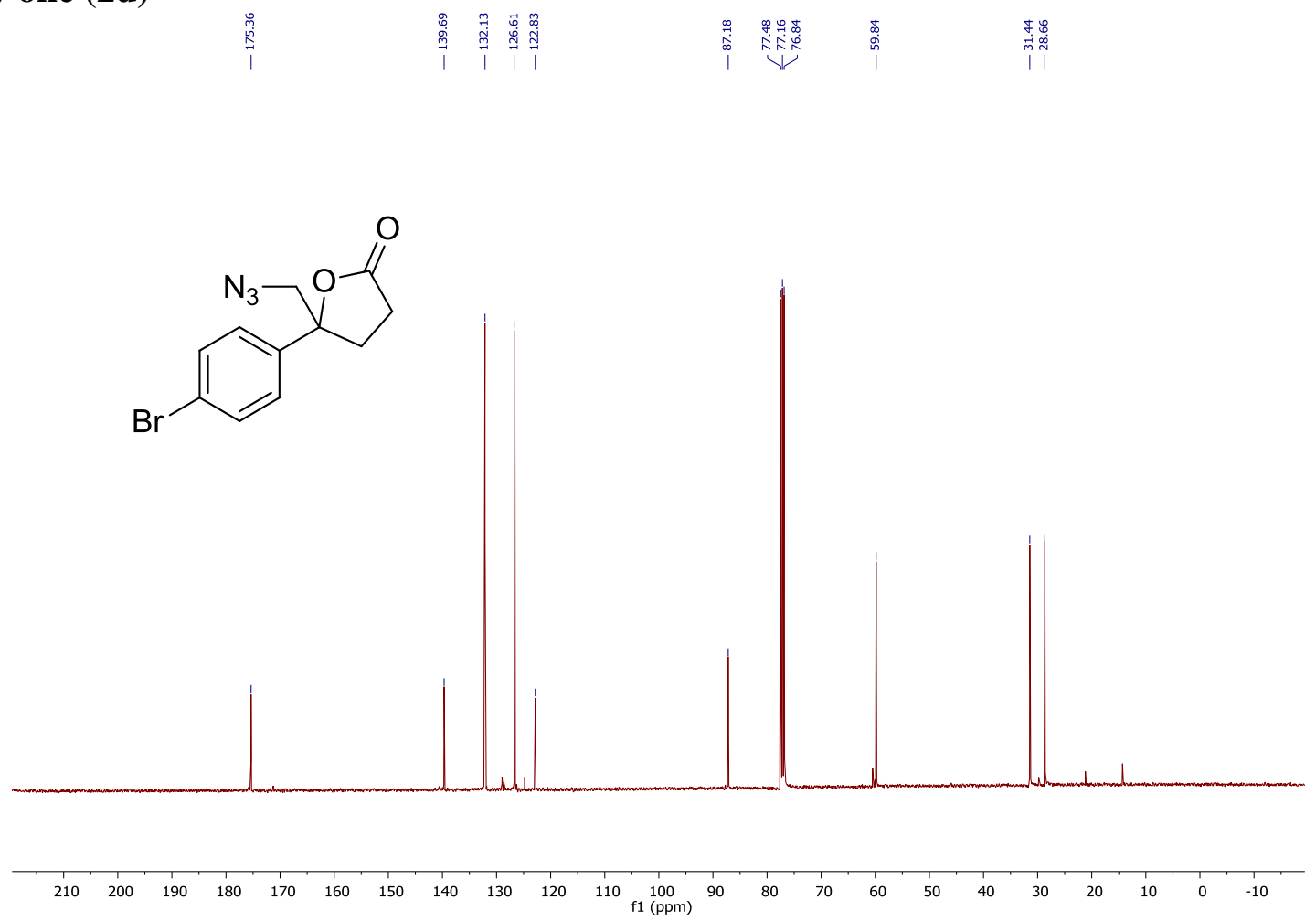

${ }^{\mathbf{1}} \mathbf{H}$ NMR (400 MHz, $\mathrm{CDCl}_{3}$ ) of compound 5-(azidomethyl)-5-(4-fluorophenyl)dihydrofuran2(3H)-one (2e)

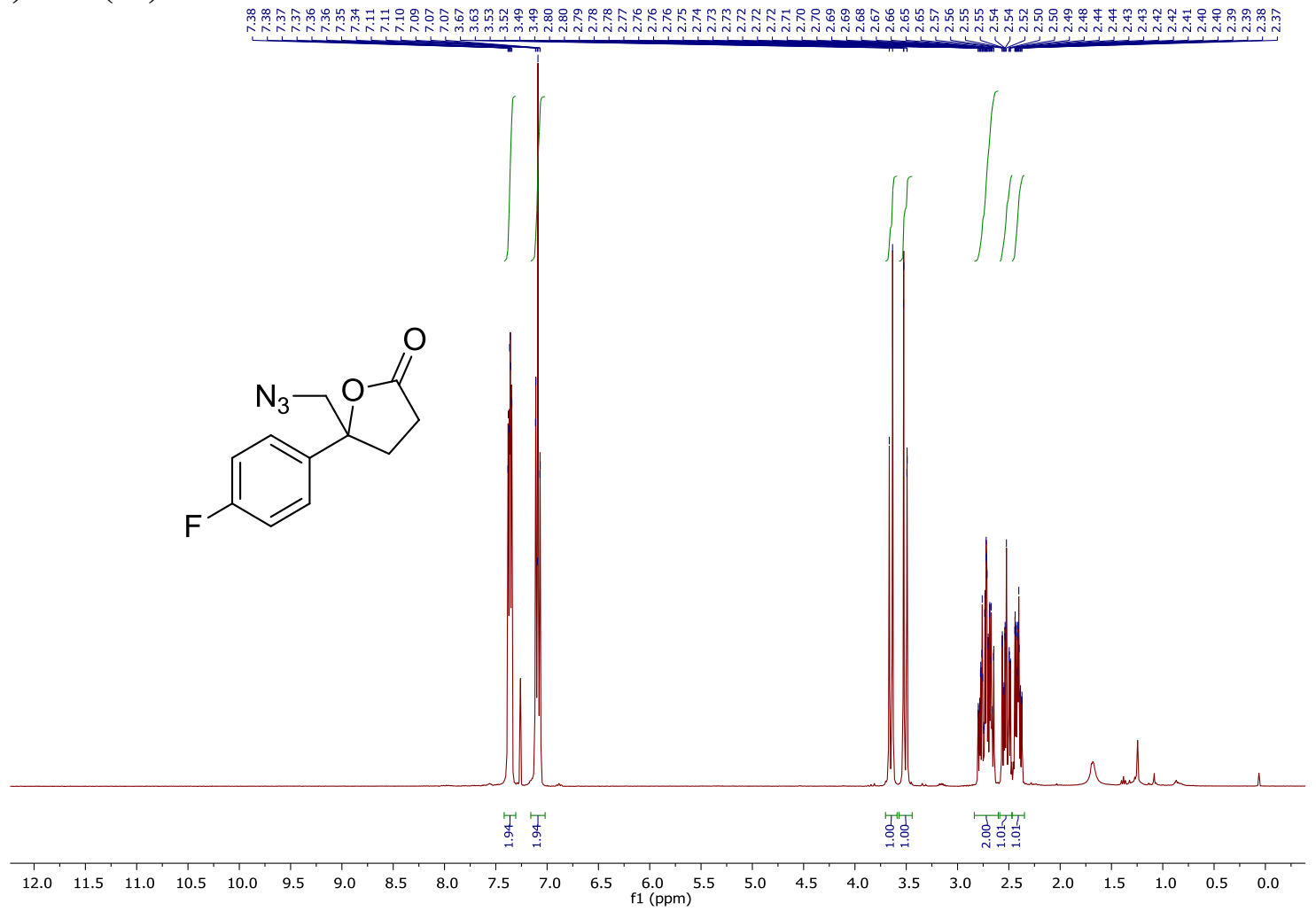


${ }^{13} \mathrm{C}$ NMR (101 MHz, $\mathrm{CDCl}_{3}$ ) of compound 5-(azidomethyl)-5-(4-fluorophenyl)dihydrofuran2(3H)-one (2e)

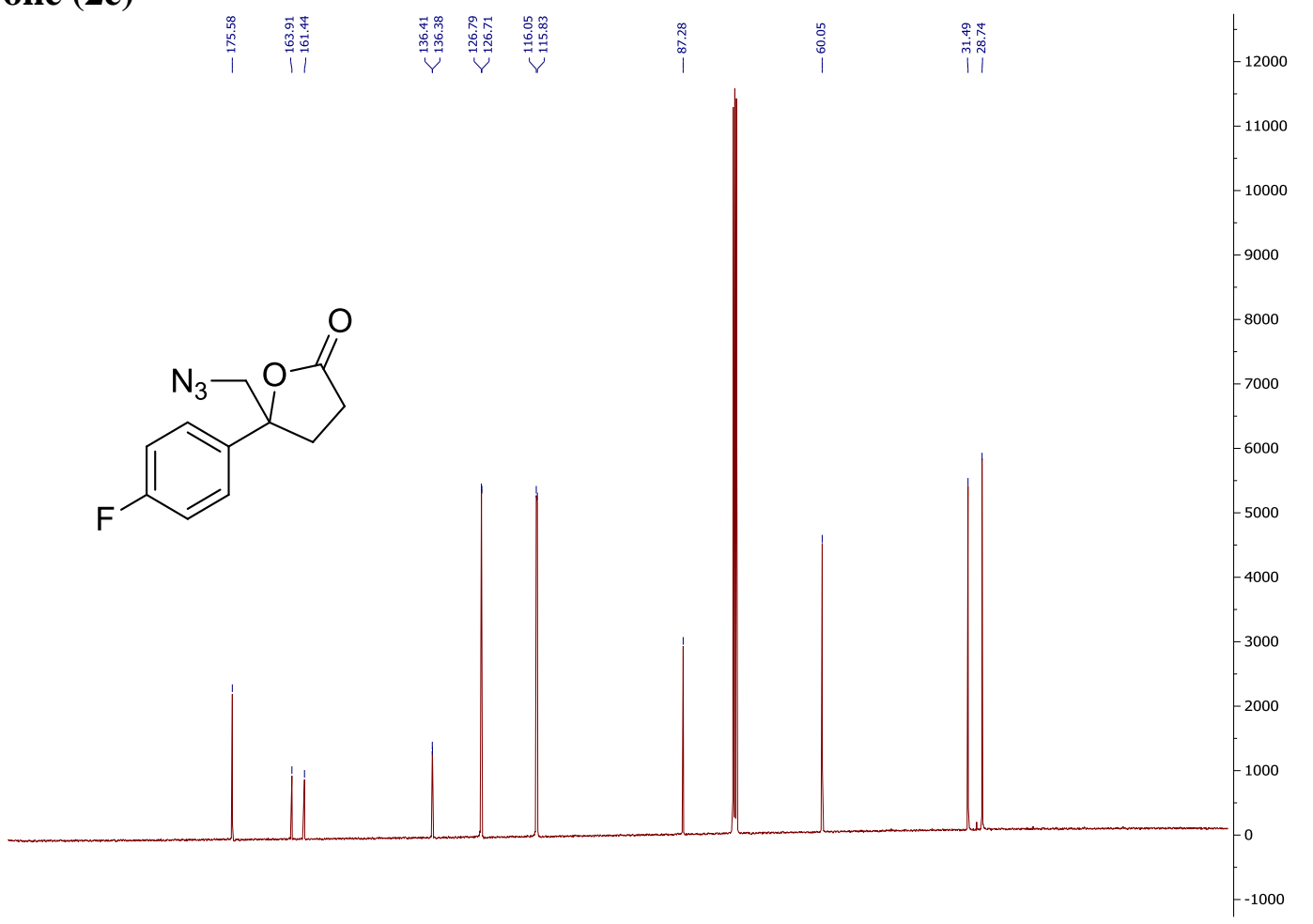

${ }^{19}$ F NMR $\left(376 \mathrm{MHz}, \mathrm{CDCl}_{3}\right.$ ) of compound 5-(azidomethyl)-5-(4-fluorophenyl)dihydrofuran2(3H)-one (2e)

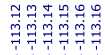

(1)

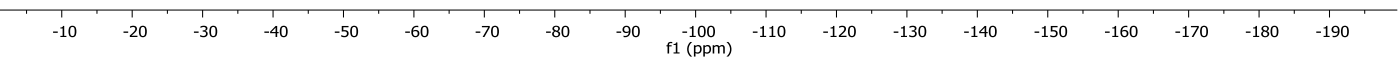


IR of compound 5-(azidomethyl)-5-(4-fluorophenyl)dihydrofuran-2(3H)-one (2e)

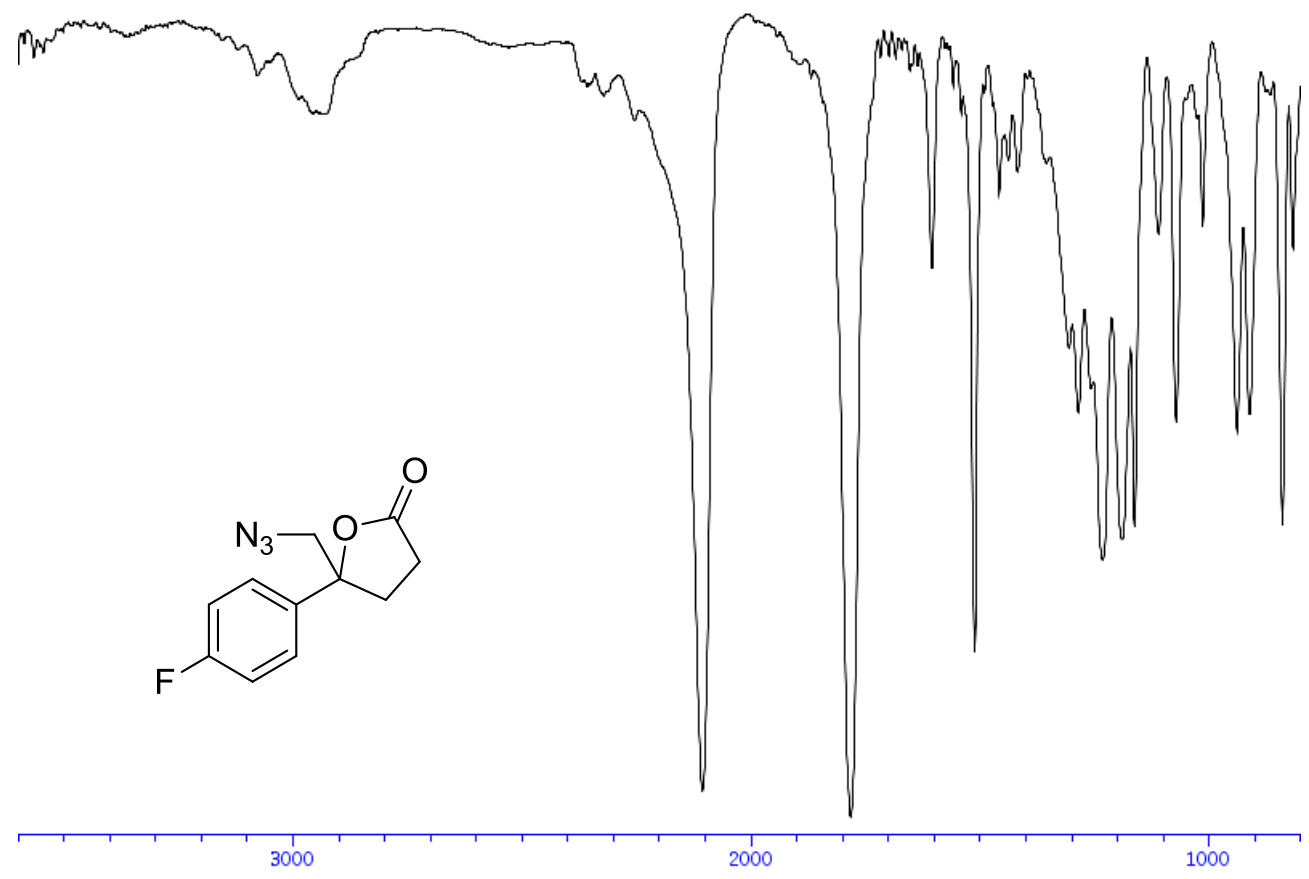

${ }^{1} \mathbf{H}$ NMR (400 MHz, $\mathrm{CDCl}_{3}$ ) of compound 5-(azidomethyl)-5-(4-chlorophenyl)dihydrofuran2(3H)-one (2f)

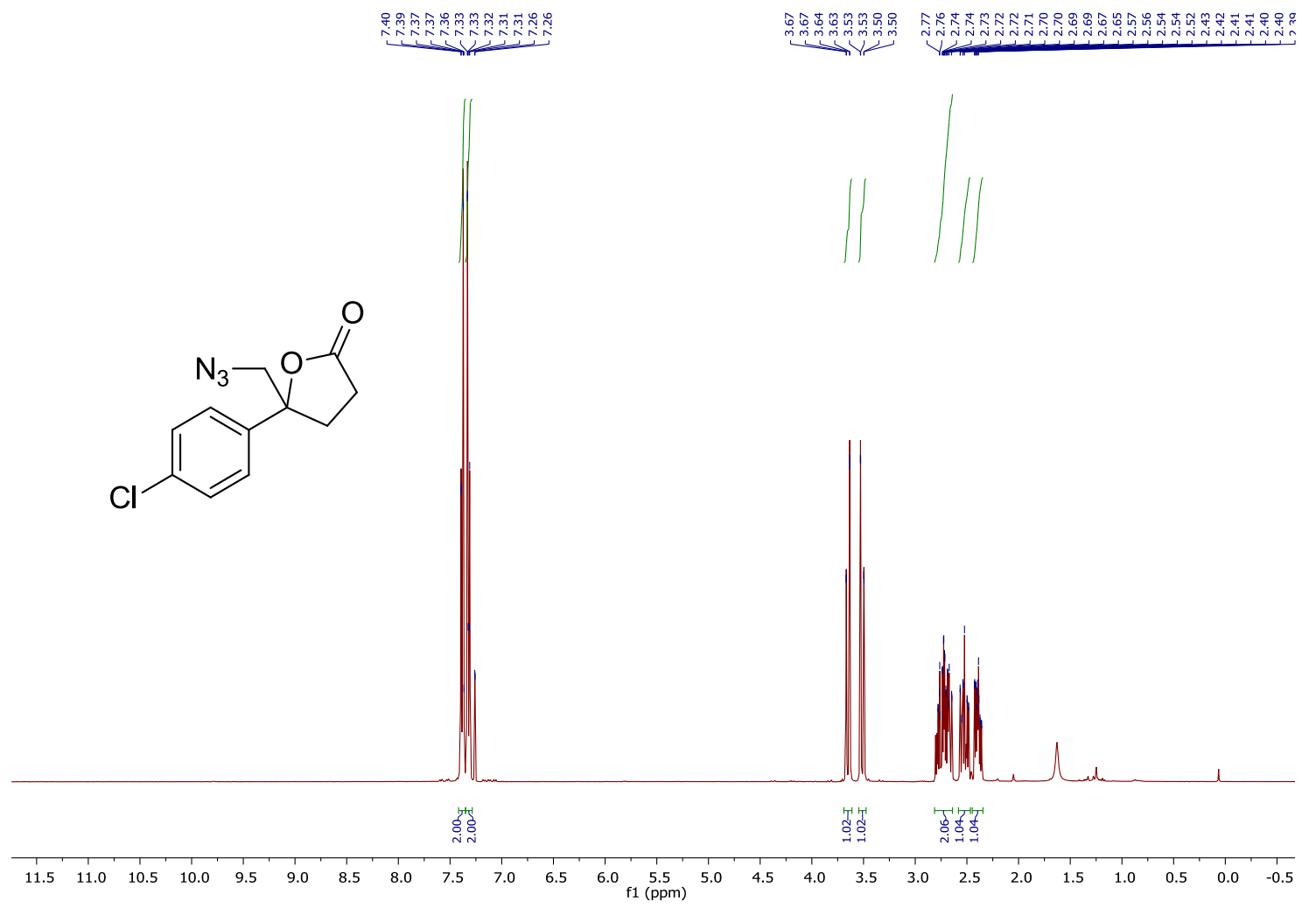


${ }^{13} \mathrm{C}$ NMR (101 MHz, $\mathrm{CDCl}_{3}$ ) of compound 5-(azidomethyl)-5-(4-chlorophenyl)dihydrofuran2(3H)-one (2f)

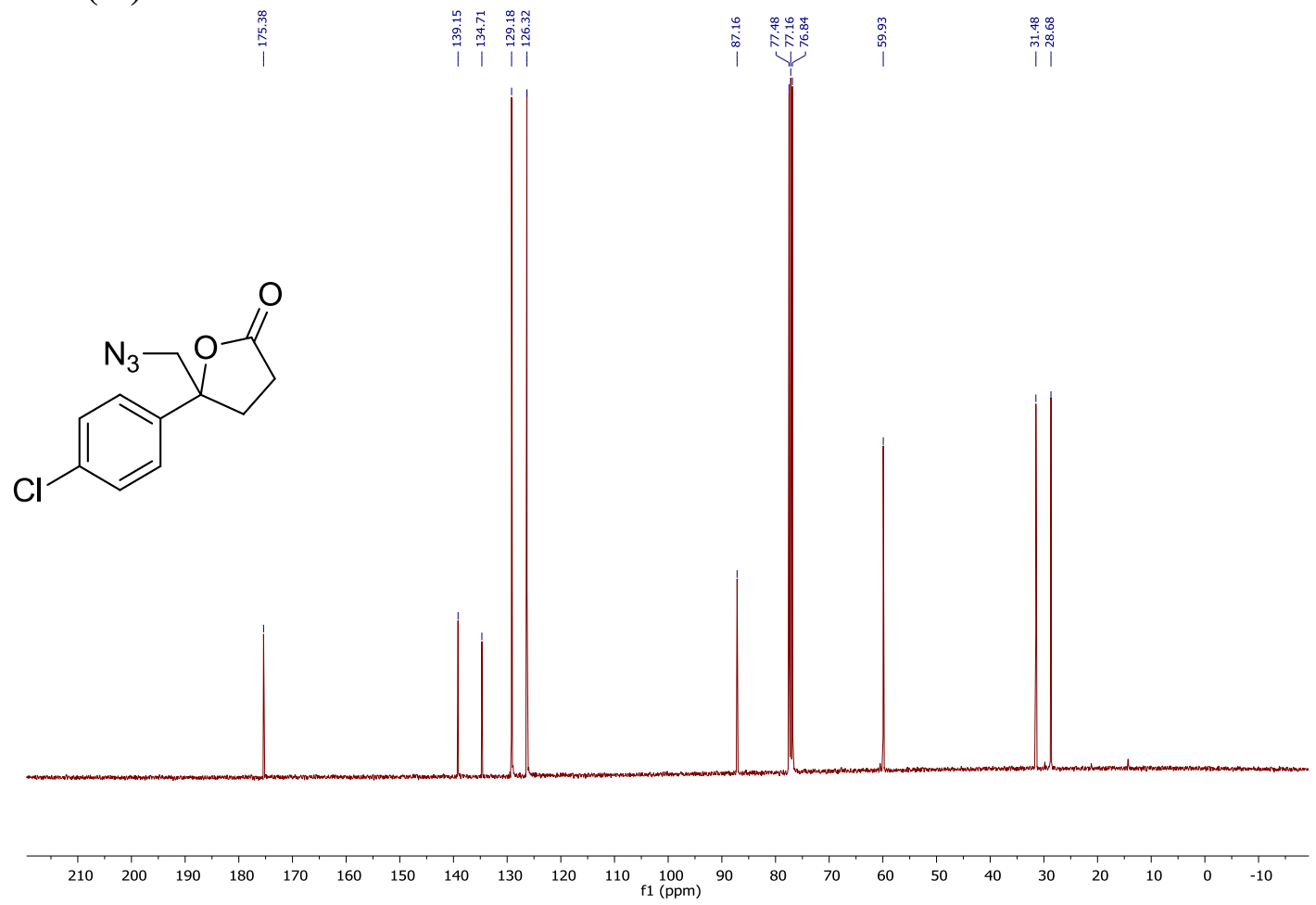

${ }^{\mathbf{1}} \mathbf{H}$ NMR (400 MHz, $\mathrm{CDCl}_{3}$ ) of compound 3-(azidomethyl)-3-methylisobenzofuran-1(3H)-one $(2 \mathrm{~g})$

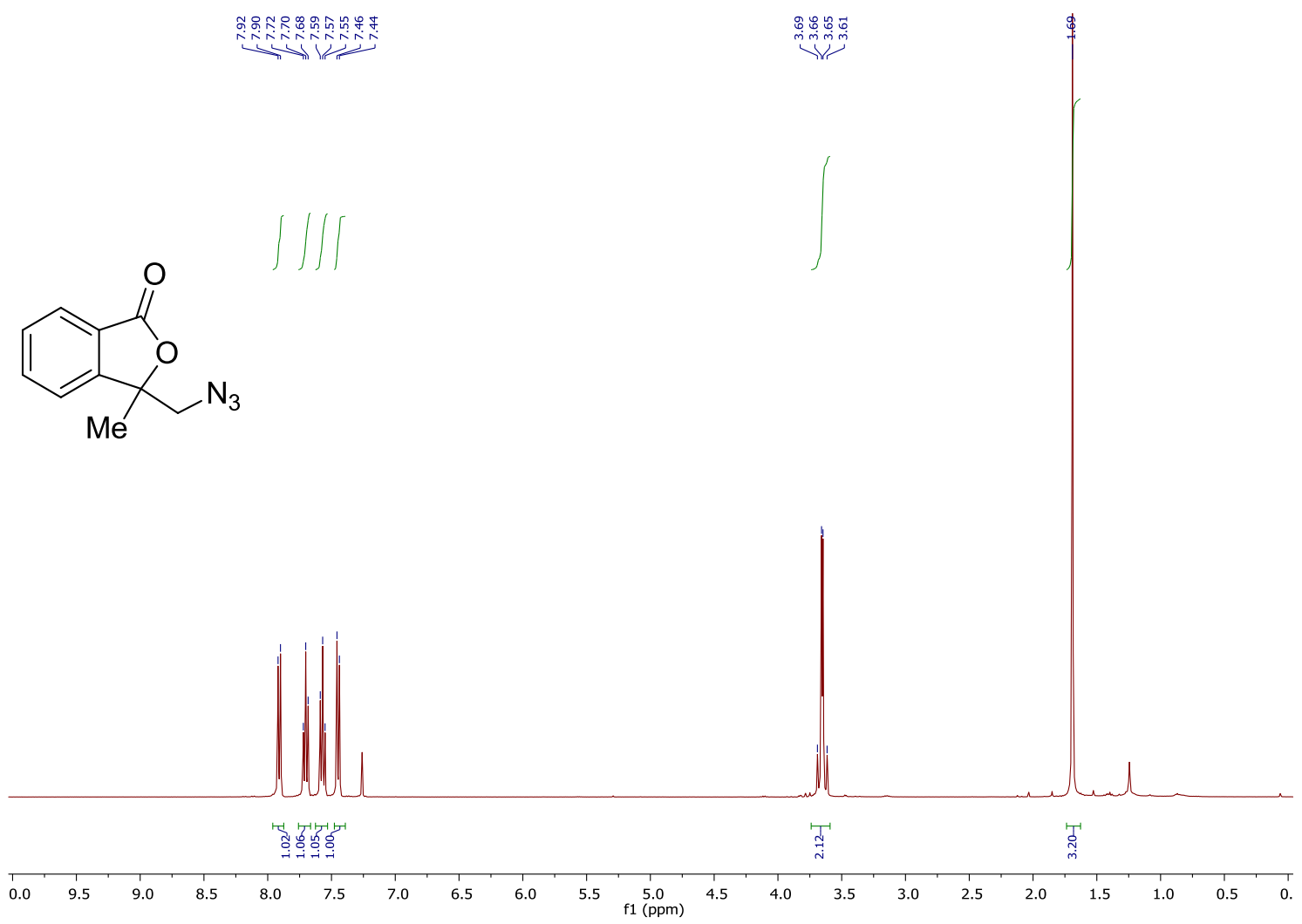


${ }^{13} \mathrm{C}$ NMR (101 MHz, $\mathrm{CDCl}_{3}$ ) of compound 3-(azidomethyl)-3-methylisobenzofuran-1(3H)one (2g)

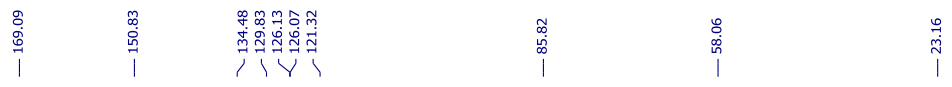<smiles>CC1(CN)OC(=O)c2ccccc21</smiles>
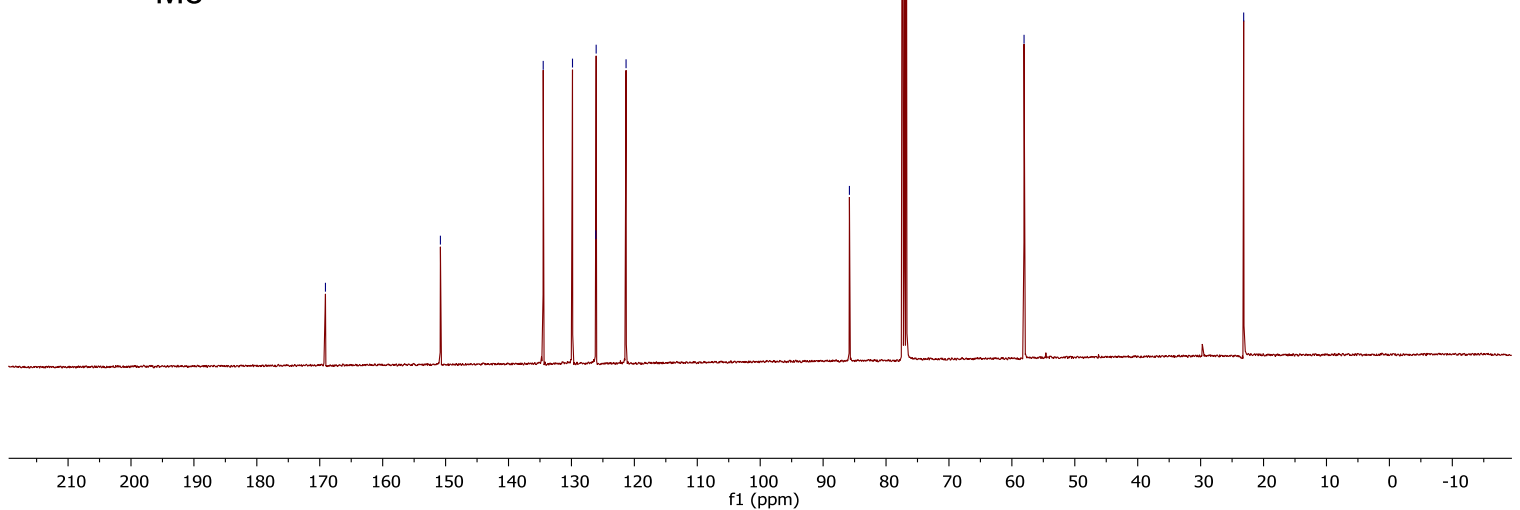

IR of compound 3-(azidomethyl)-3-methylisobenzofuran-1(3H)-one (2g)

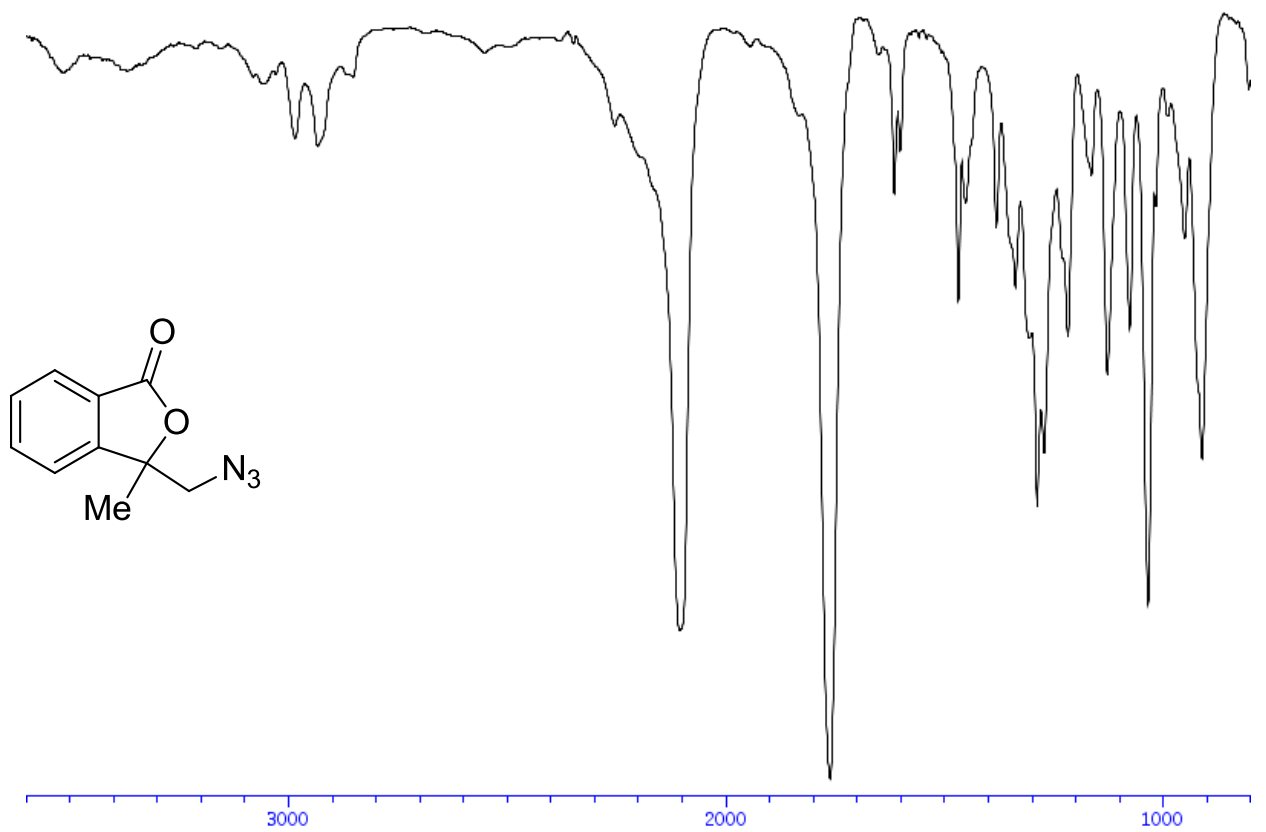


${ }^{\mathbf{1}} \mathbf{H}$ NMR (400 MHz, $\mathrm{CDCl}_{3}$ ) of compound 3-(azidomethyl)-3-phenylisobenzofuran-1(3H)-one (2h)

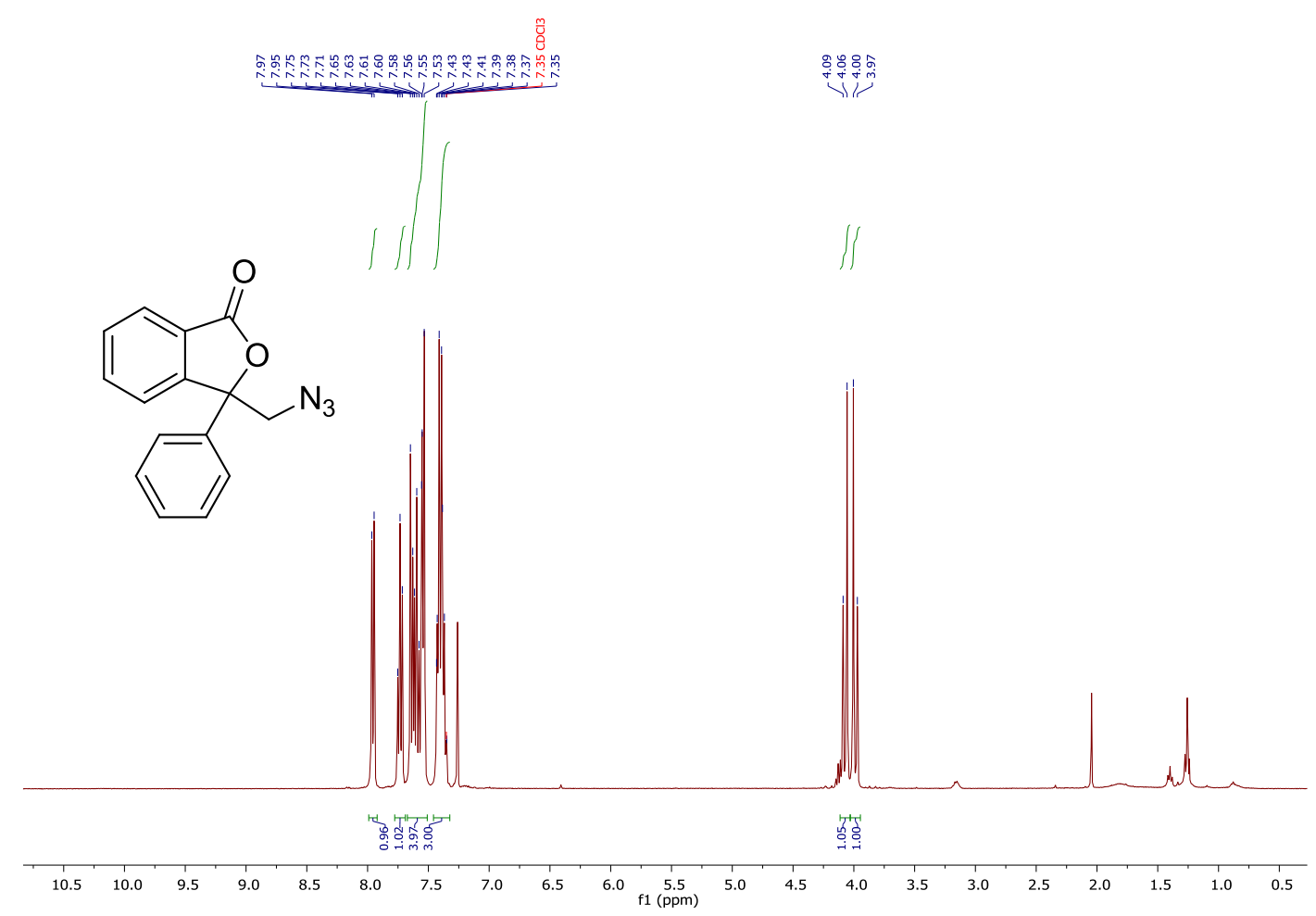

${ }^{13} \mathrm{C}$-NMR (101 MHz, $\mathrm{CDCl}_{3}$ ) of compound 3-(azidomethyl)-3-phenylisobenzofuran-1(3H)one (2h)
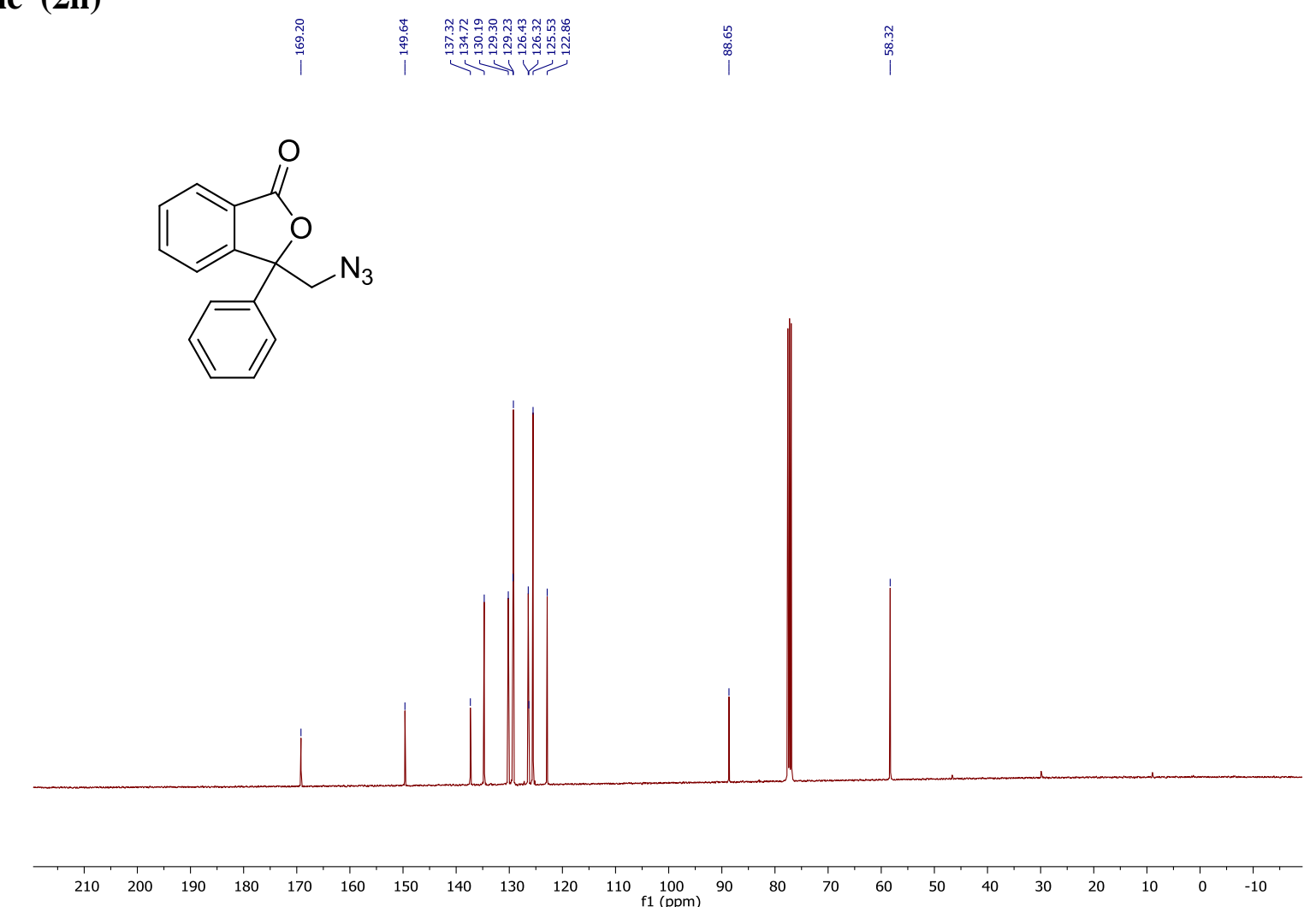
IR of compound 3-(azidomethyl)-3-phenylisobenzofuran-1(3H)-one (2h)

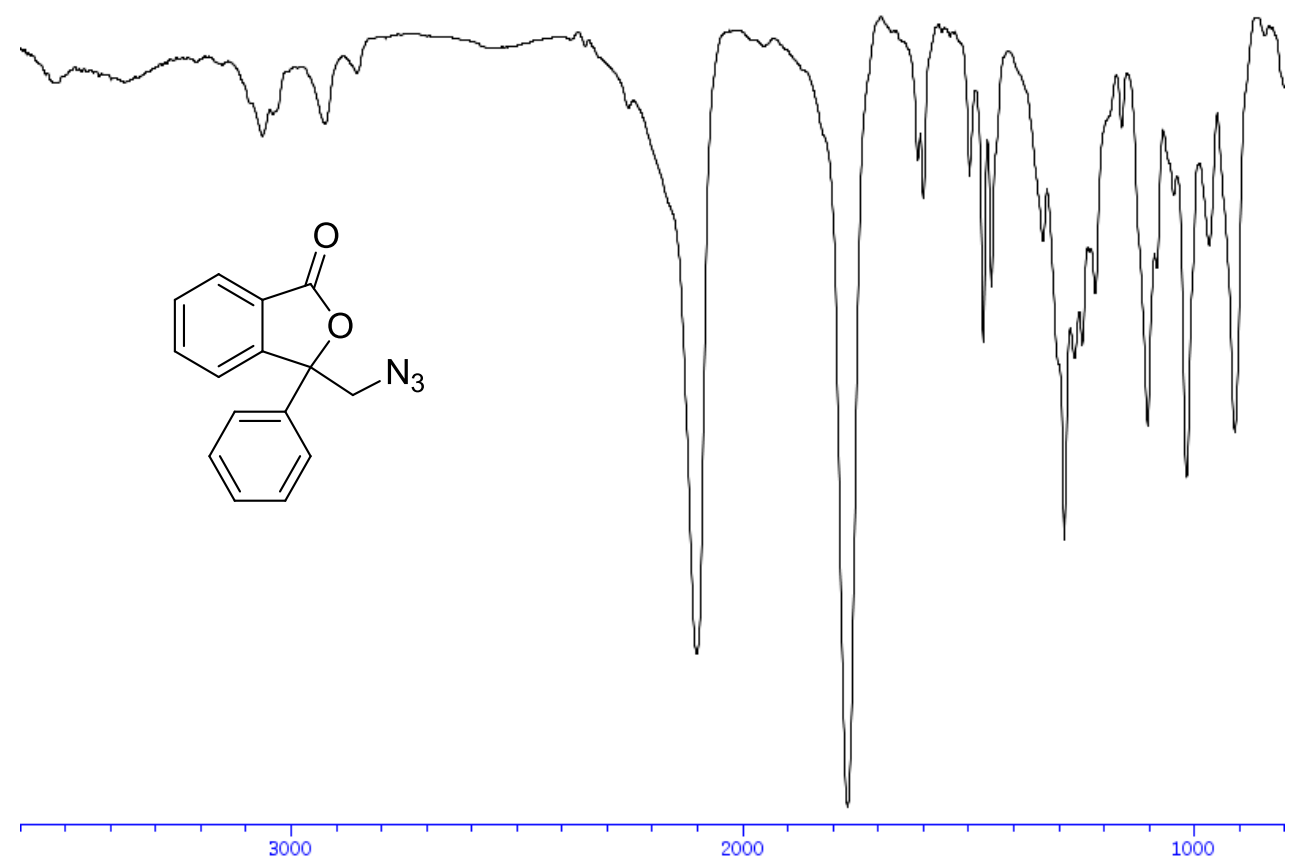

${ }^{1} \mathbf{H}$ NMR (400 MHz, $\mathrm{CDCl}_{3}$ ) of compound 3-(azidomethyl)-3-(4-fluorophenyl)isobenzofuran1(3H)-one (2i)

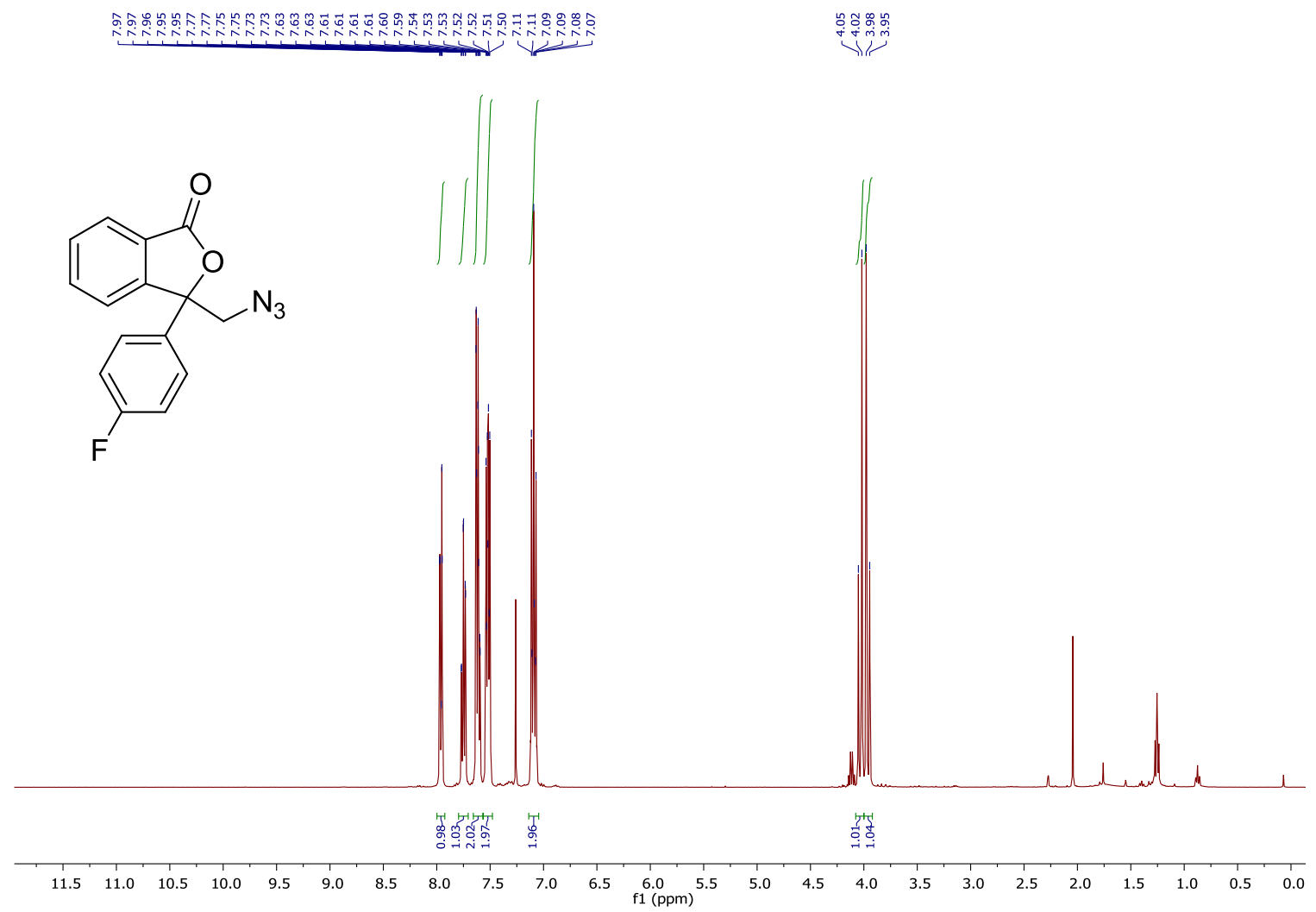


${ }^{13} \mathbf{C ~ N M R}\left(101 \mathrm{MHz}, \mathrm{CDCl}_{3}\right)$ of compound 3-(azidomethyl)-3-(4-fluorophenyl)isobenzofuran1(3H)-one (2i)
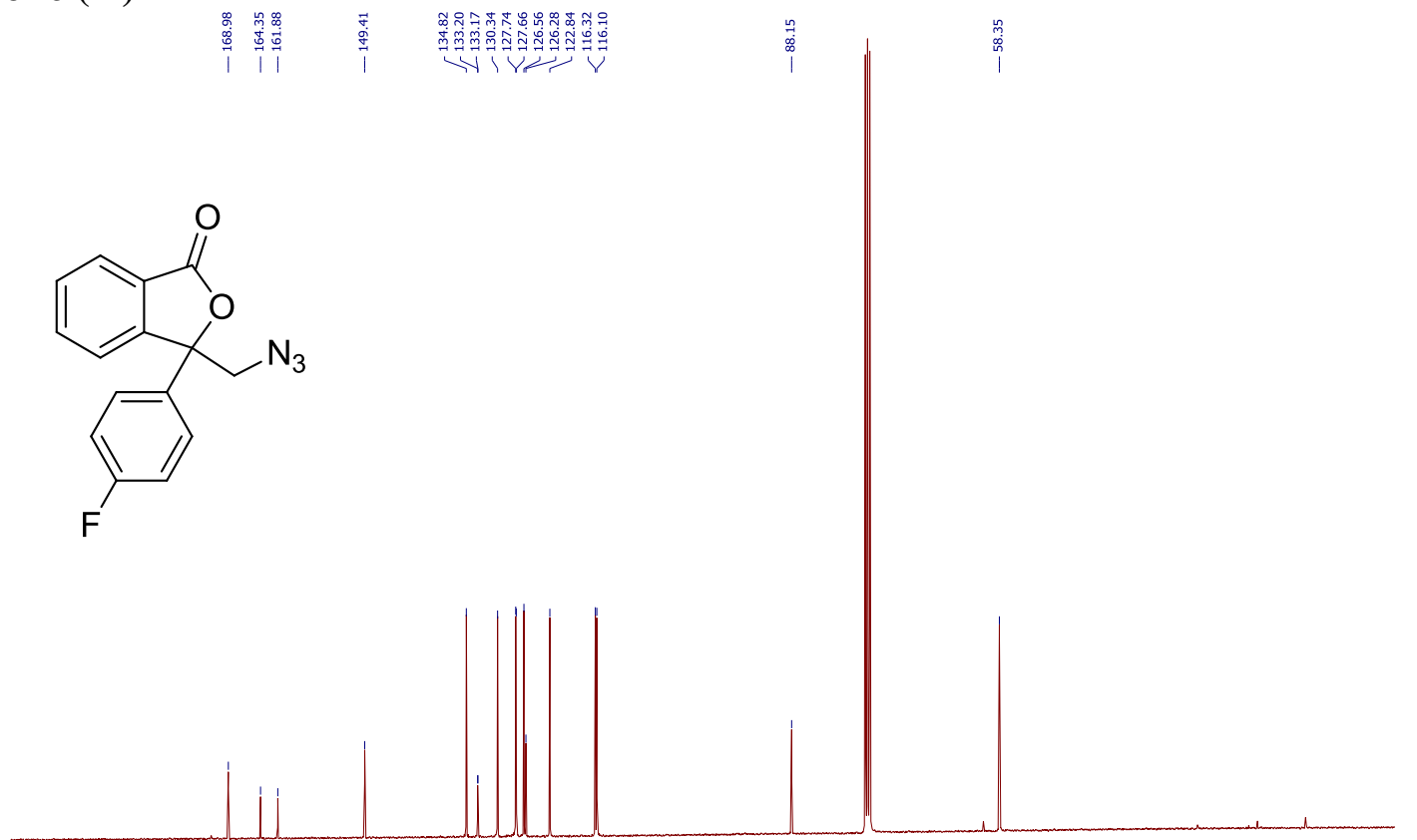

${ }^{19}$ F NMR $\left(376 \mathrm{MHz}, \mathrm{CDCl}_{3}\right.$ ) of compound 3-(azidomethyl)-3-(4-fluorophenyl)isobenzofuran1(3H)-one (2i)

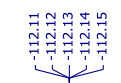<smiles>NCC1(c2ccc(F)cc2)OC(=O)c2ccccc21</smiles> 
IR of compound 3-(azidomethyl)-3-(4-fluorophenyl)isobenzofuran-1(3H)-one (2i)

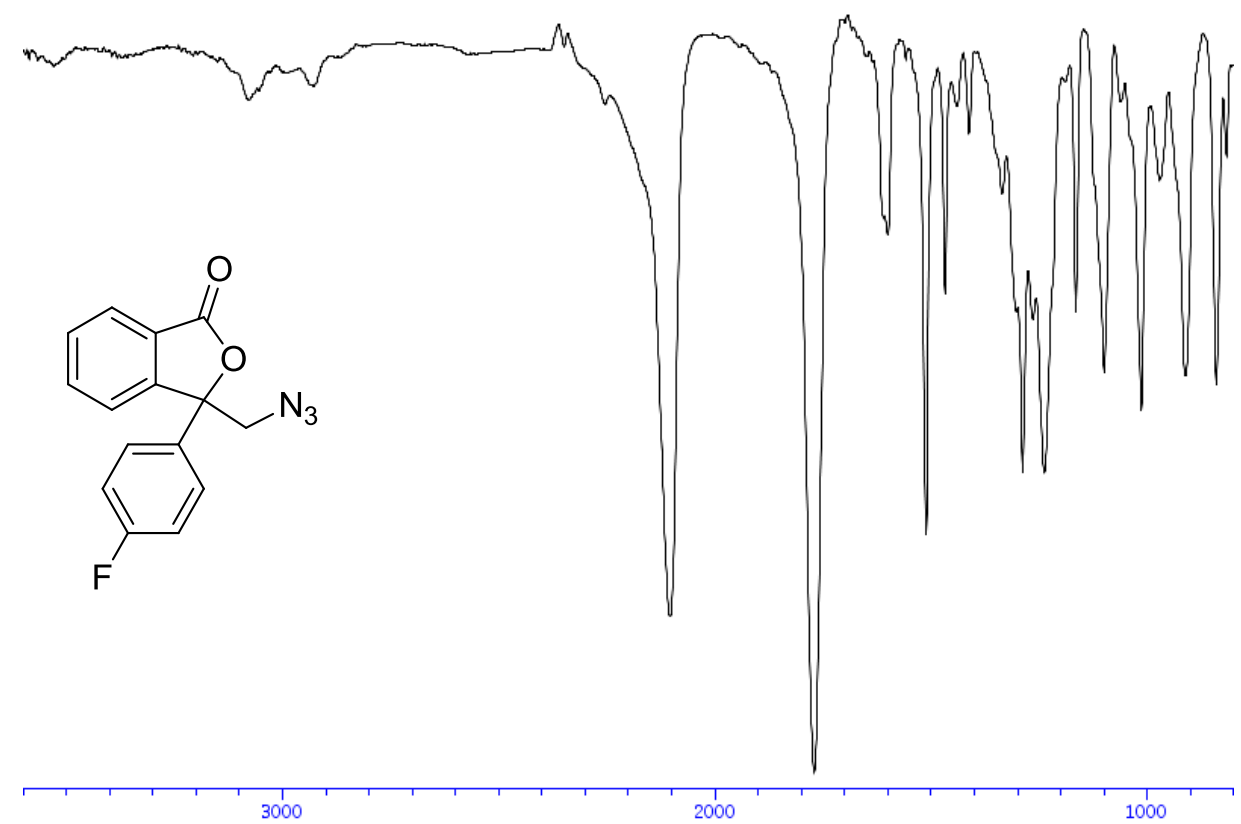

${ }^{1} \mathbf{H}$ NMR (400 MHz, $\mathrm{CDCl}_{3}$ ) of compound5-(azidomethyl)-3,3-dimethyl-5phenyldihydrofuran-2(3H)-one $(2 \mathbf{j})$

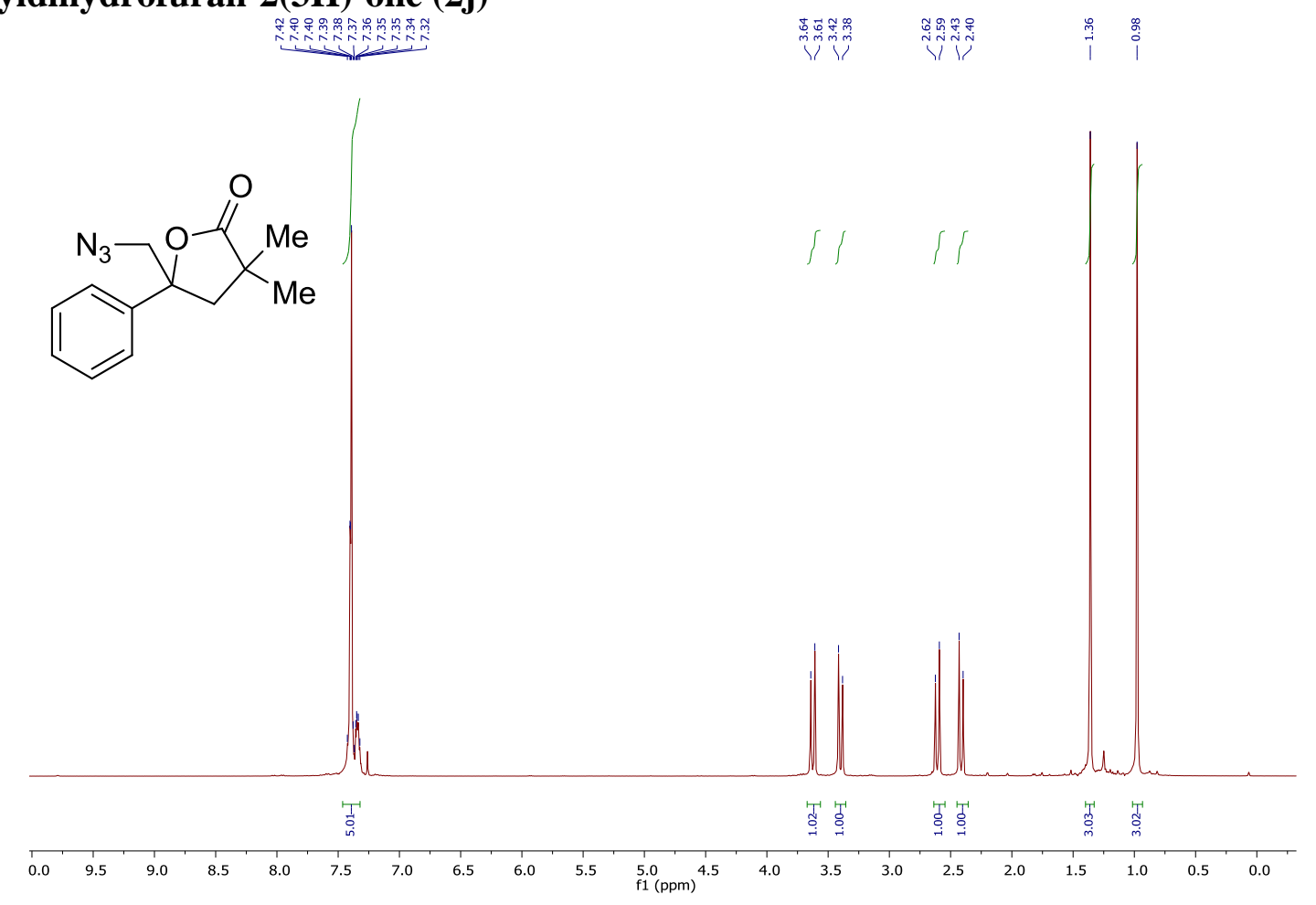


${ }^{13}$ C NMR (101 MHz, $\mathrm{CDCl}_{3}$ ) of compound 5-(azidomethyl)-3,3-dimethyl-5phenyldihydrofuran-2(3H)-one $(2 \mathbf{j})$

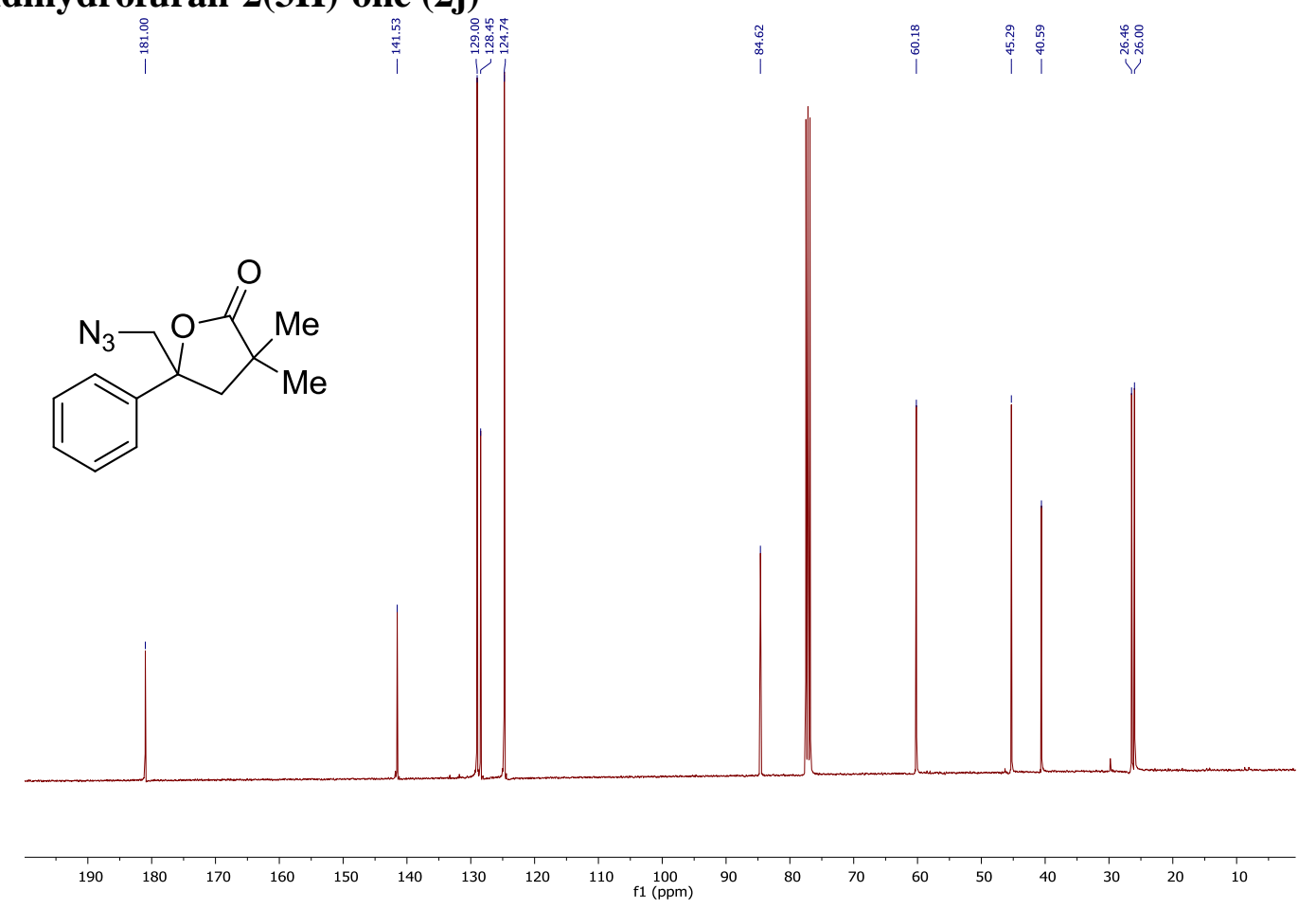

IR of compound 5-(azidomethyl)-3,3-dimethyl-5-phenyldihydrofuran-2(3H)-one (2j)

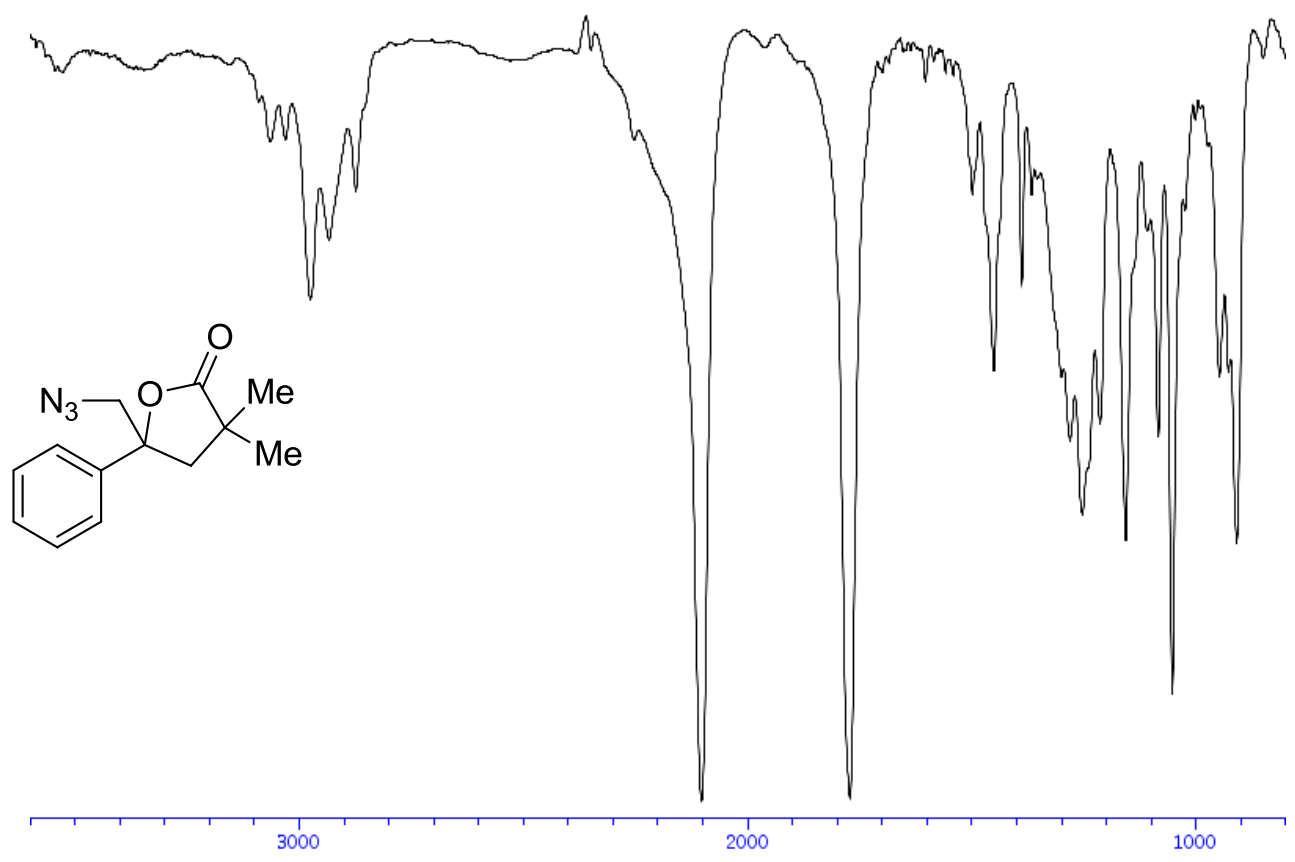


${ }^{1} \mathbf{H}$ NMR $\left(400 \mathrm{MHz}, \mathrm{CDCl}_{3}\right)$ of compound 5-(azidomethyl)-5-(thiophen-3-yl)dihydrofuran2(3H)-one (2k)

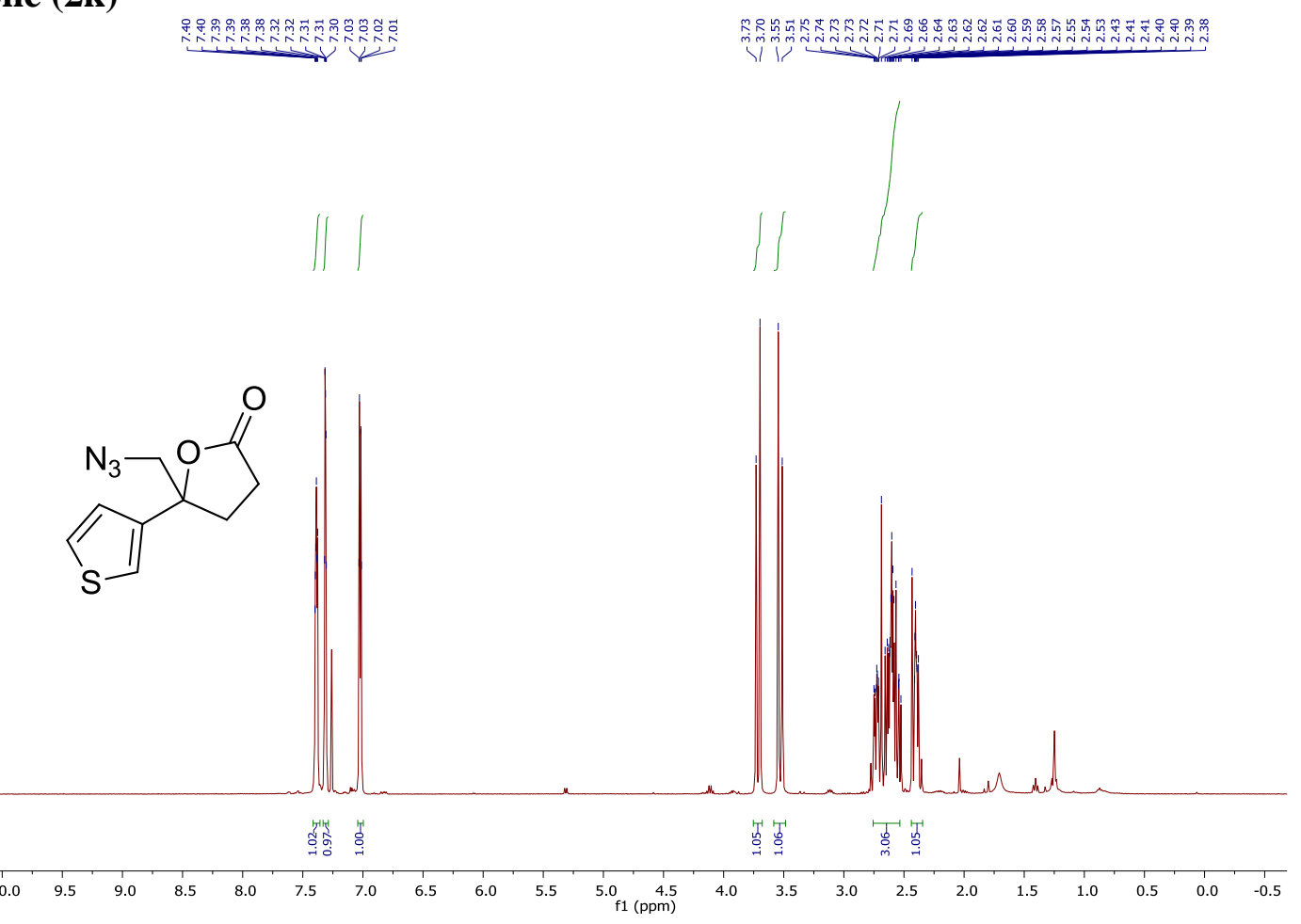

${ }^{13} \mathrm{C}$ NMR (101 MHz, $\mathrm{CDCl}_{3}$ ) of compound 5-(azidomethyl)-5-(thiophen-3-yl)dihydrofuran2(3H)-one (2k)
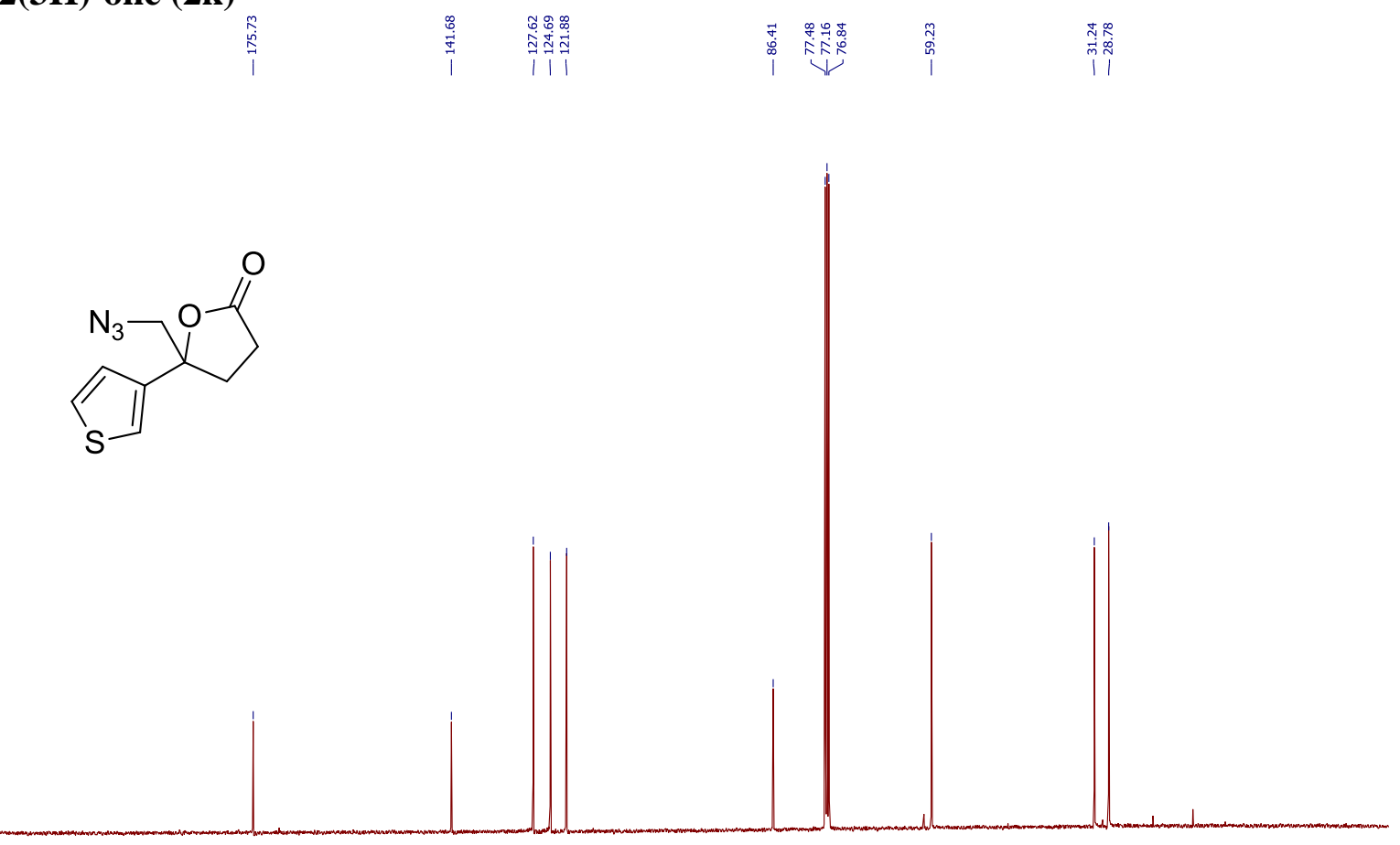

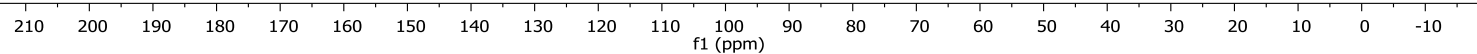


${ }^{1} \mathbf{H}$ NMR (400 MHz, $\mathrm{CDCl}_{3}$ ) of compound 5-(azidomethyl)-5-(2,5dimethylphenyl)dihydrofuran-2(3H)-one (2I)

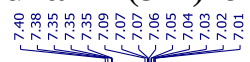

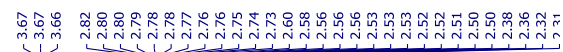
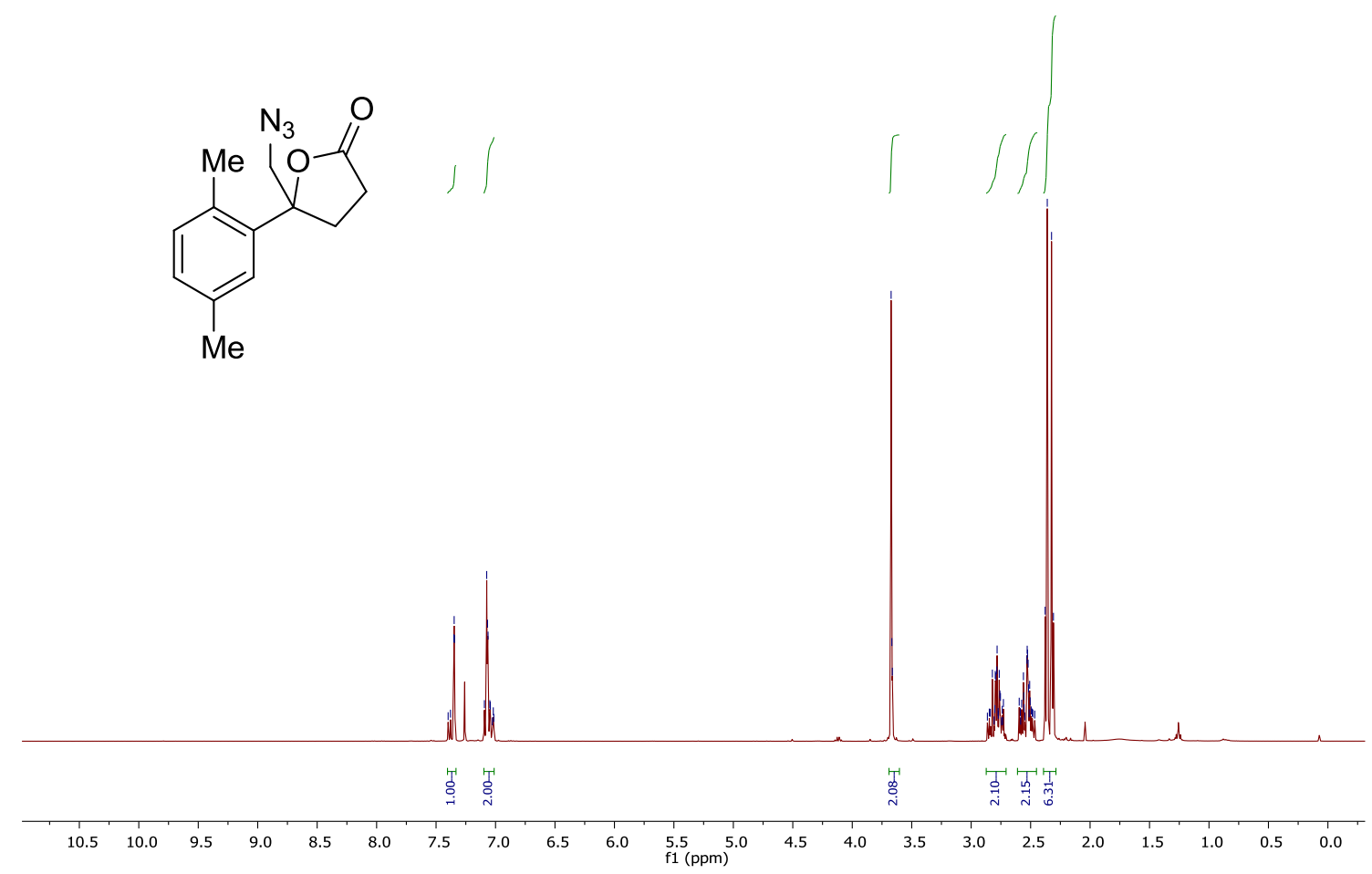

${ }^{13} \mathrm{C}$ NMR (101 MHz, $\left.\mathrm{CDCl}_{3}\right)$ of compound -(azidomethyl)-5-(2,5-

dimethylphenyl)dihydrofuran-2(3H)-one (2l)
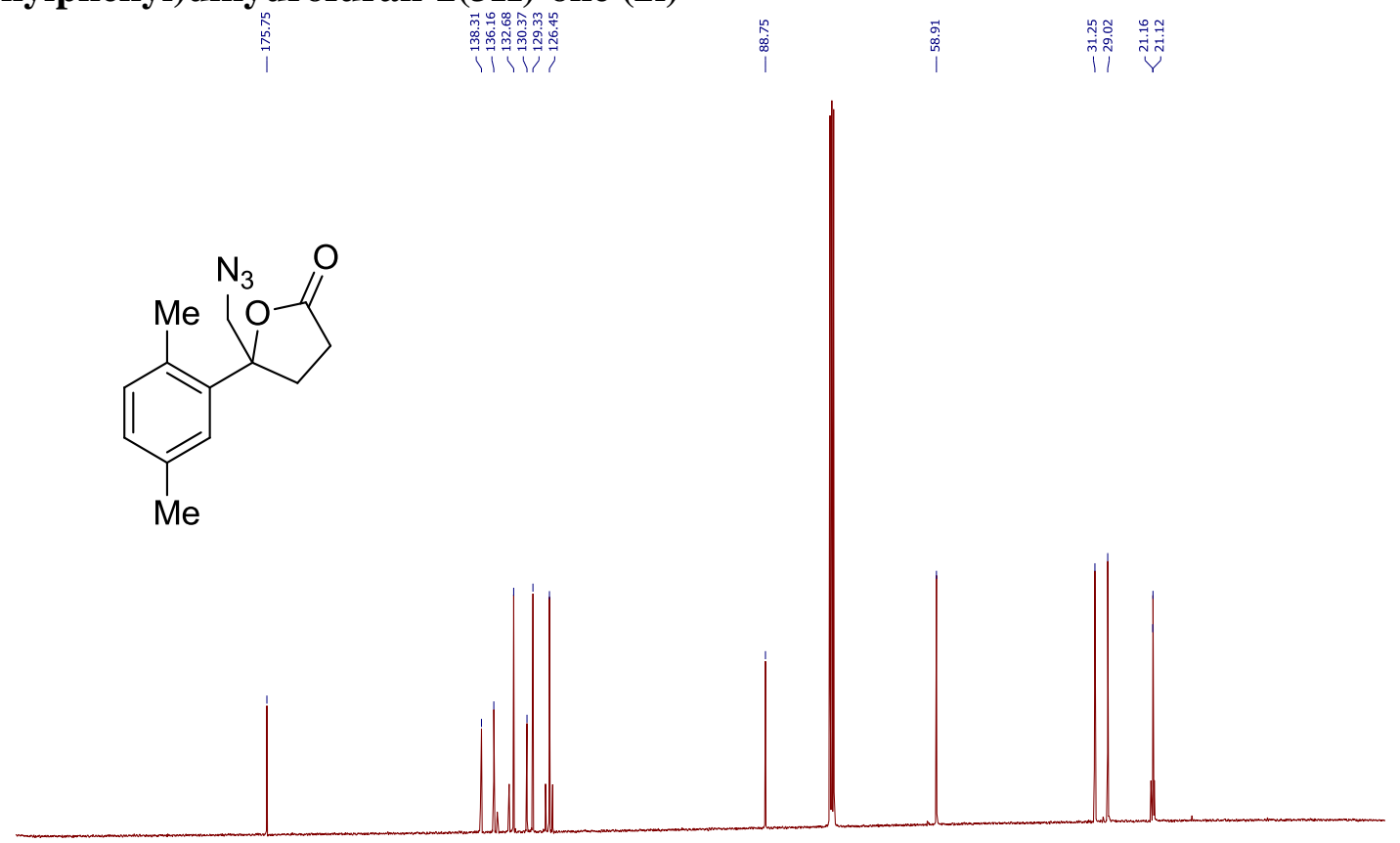

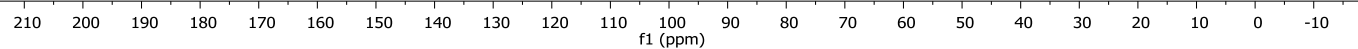


IR of compound -(azidomethyl)-5-(2,5-dimethylphenyl)dihydrofuran-2(3H)-one (2I)

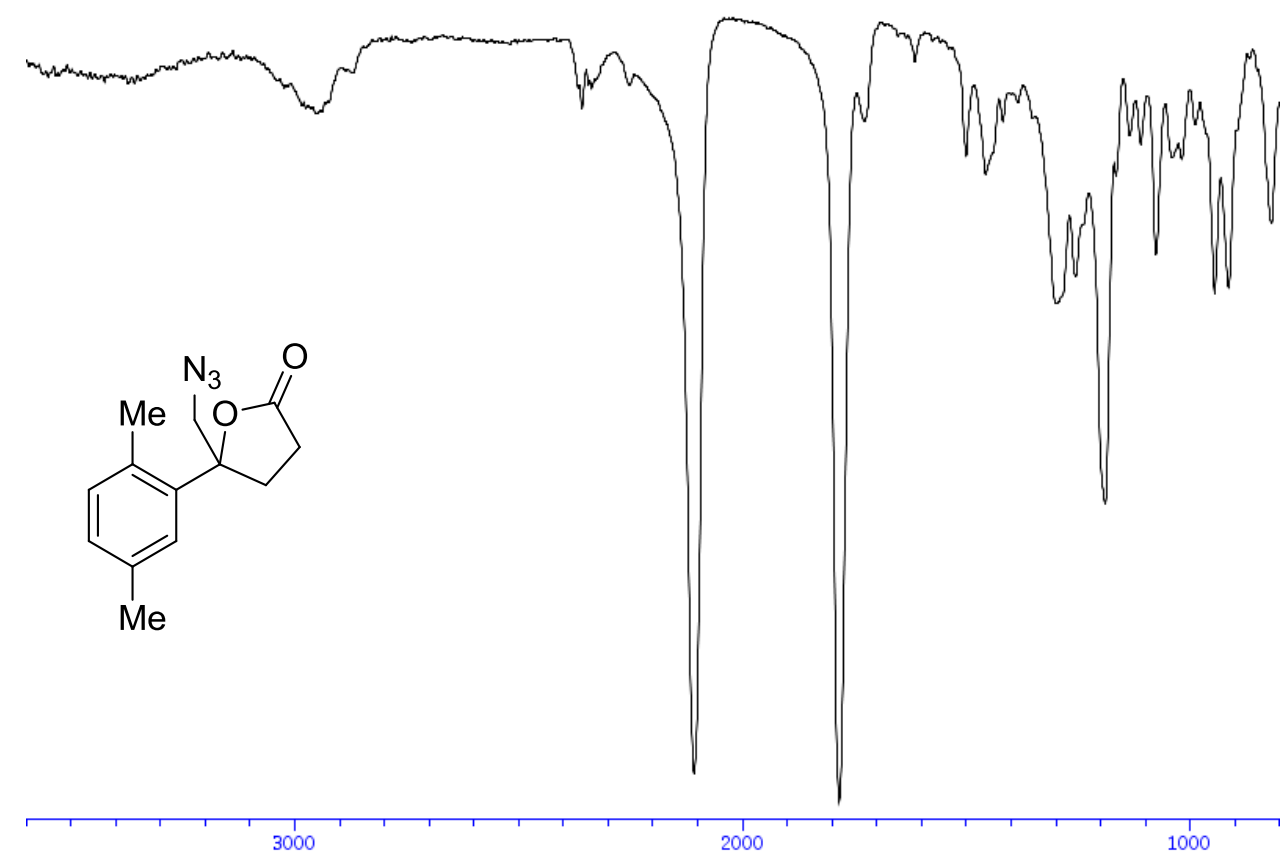

${ }^{1} \mathbf{H}$ NMR (400 MHz, $\mathrm{CDCl}_{3}$ ) of compound $\mathbf{8 b}$-(azidomethyl)-3,3a,4,8b-tetrahydro-2Hindeno[1,2-b]furan-2-one (2m)

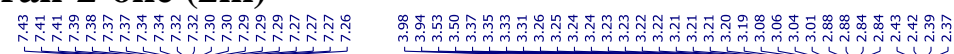
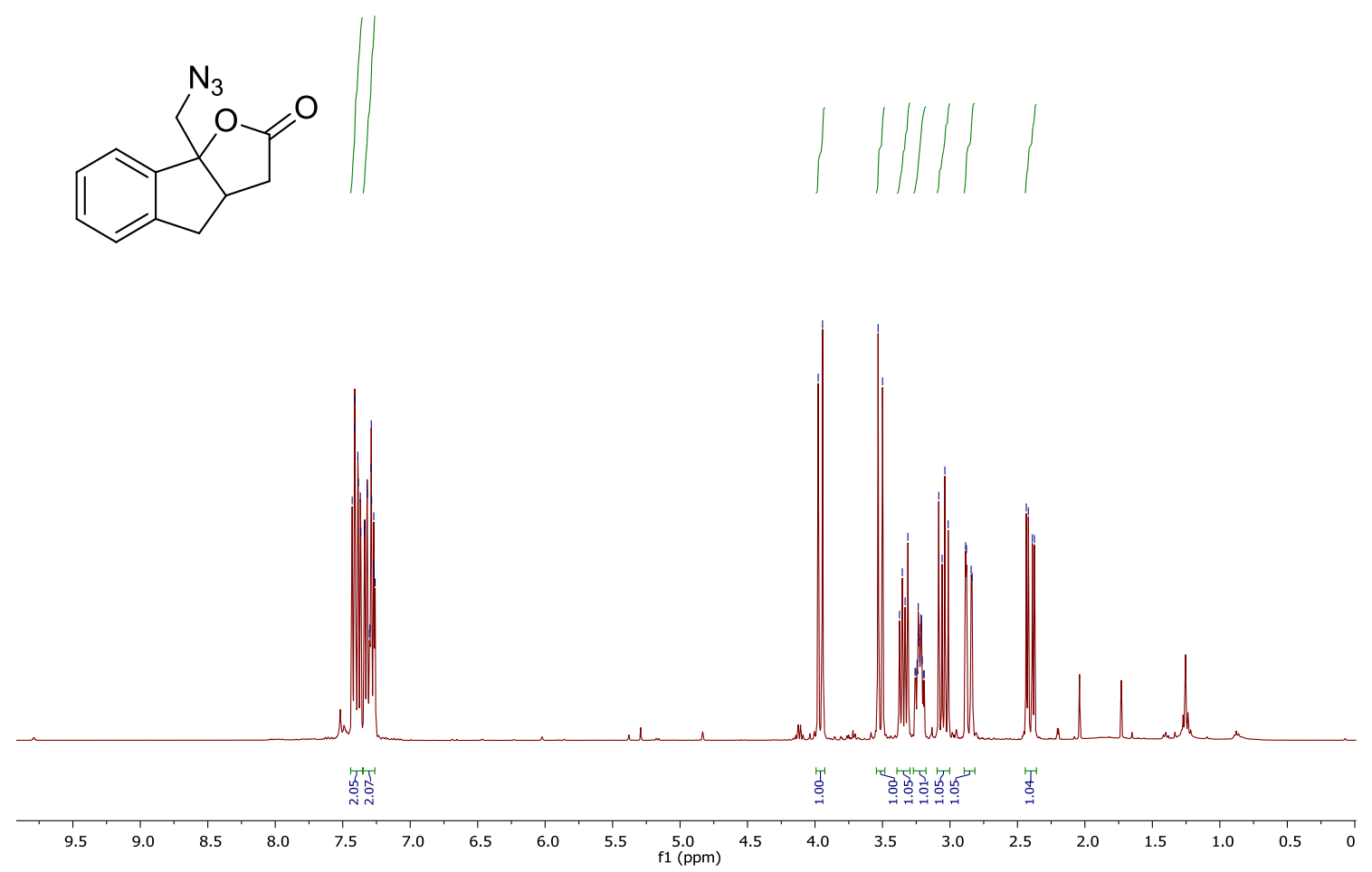
${ }^{13} \mathrm{C} \mathrm{NMR}\left(101 \mathrm{MHz}, \mathrm{CDCl}_{3}\right)$ of compound 8b-(azidomethyl)-3,3a,4,8b-tetrahydro-2Hindeno[1,2-b]furan-2-one (2m)
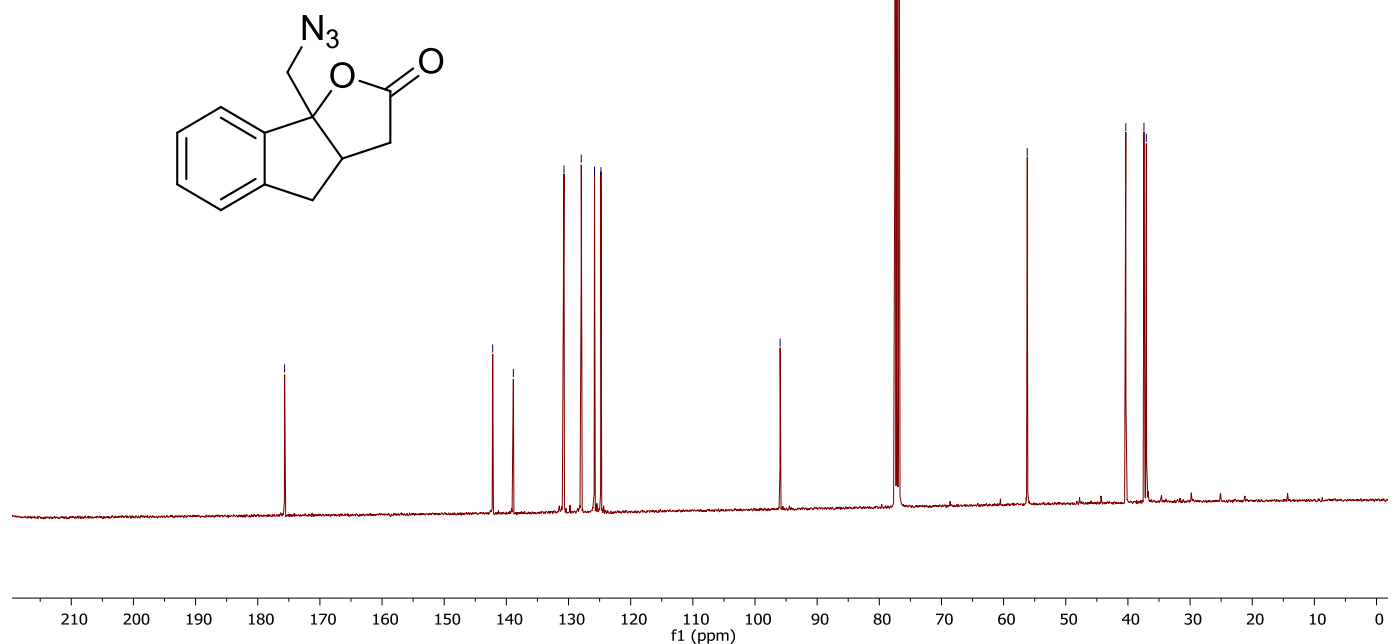

IR of compound 8b-(azidomethyl)-3,3a,4,8b-tetrahydro-2H-indeno[1,2-b]furan-2-one (2m)

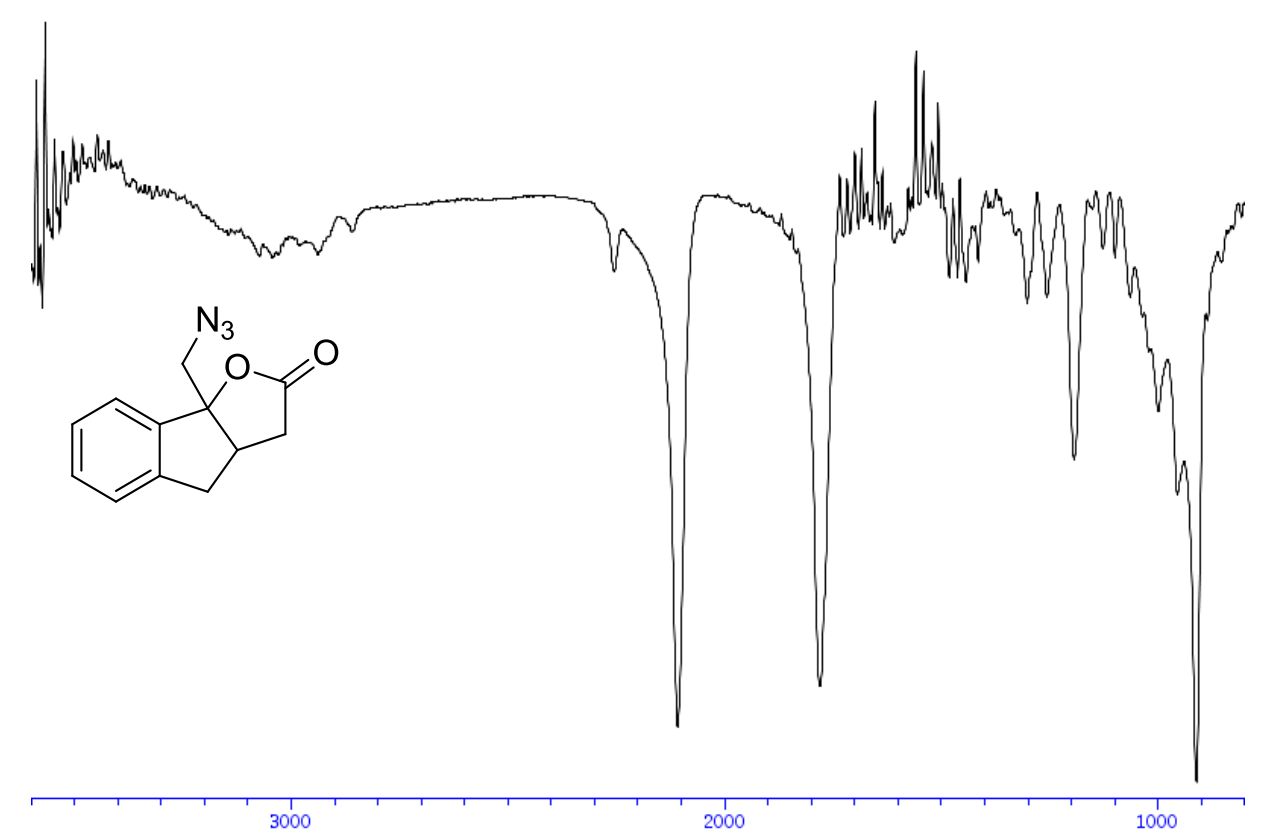


${ }^{1} \mathbf{H}$ NMR $\left(400 \mathrm{MHz}, \mathrm{CDCl}_{3}\right)$ of compound 5-(azidomethyl)-5-(phenylethynyl)dihydrofuran2(3H)-one (2n)
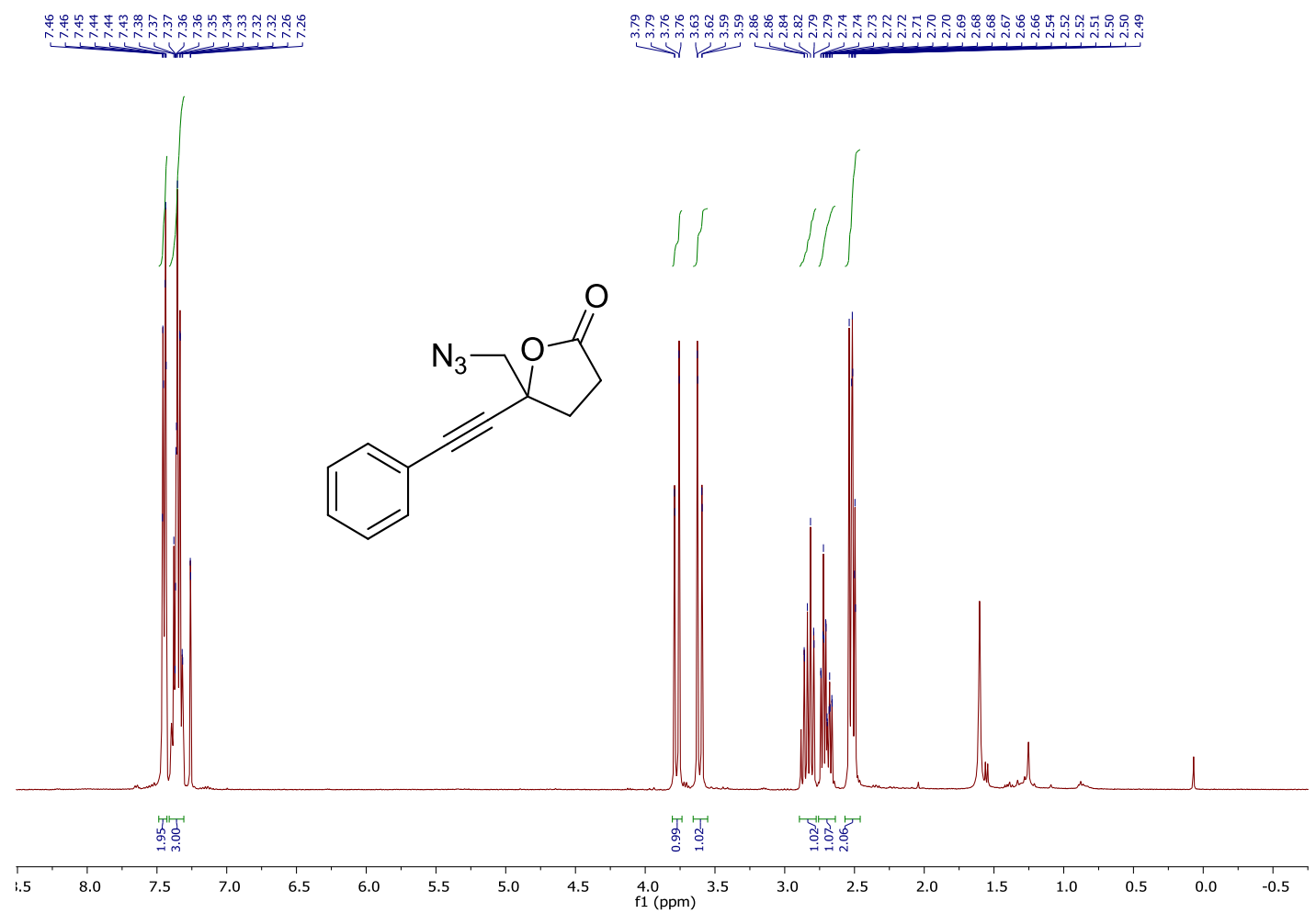

${ }^{13} \mathrm{C}$ NMR (101 MHz, $\mathrm{CDCl}_{3}$ ) of compound 5-(azidomethyl)-5-(phenylethynyl)dihydrofuran2(3H)-one (2n)
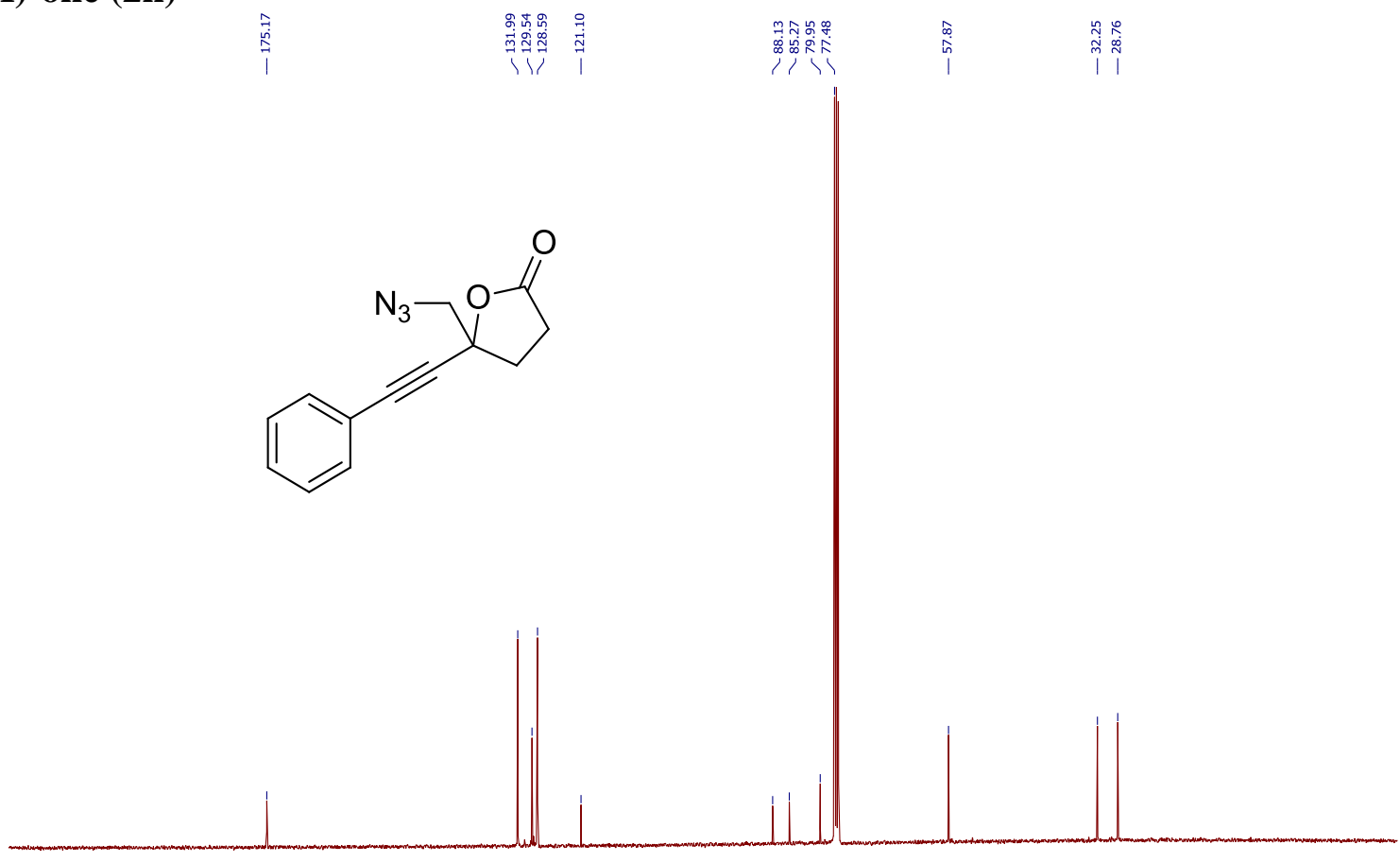

$\begin{array}{llllllllllllllllllllllllll}210 & 200 & 190 & 180 & 170 & 160 & 150 & 140 & 130 & 120 & 110 & 100 & 90 & 80 & 70 & 60 & 50 & 40 & 30 & 20 & 10 & 0 & -10\end{array}$ 
${ }^{\mathbf{1}} \mathbf{H}$ NMR (400 MHz, $\mathrm{CDCl}_{3}$ ) of compound 6-(azidomethyl)-6-phenyltetrahydro-2H-pyran-2one (2o)

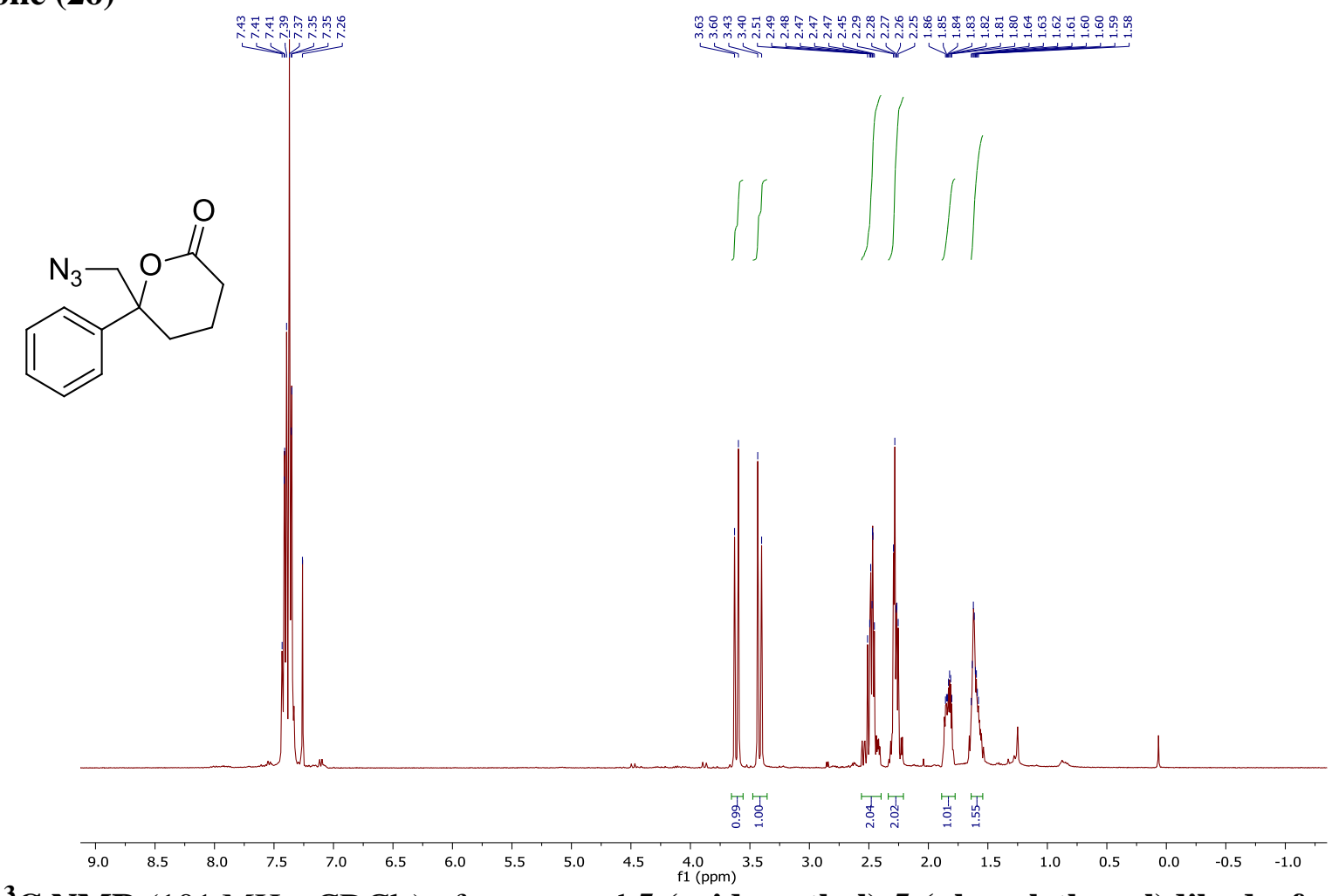

${ }^{\mathbf{1 3}} \mathrm{C}$ NMR (101 MHz, $\mathrm{CDCl}_{3}$ ) of compound 5-(azidomethyl)-5-(phenylethynyl)dihydrofuran2(3H)-one (2n)

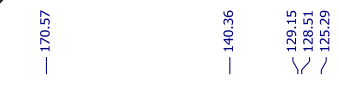<smiles>NCC1(c2ccccc2)CCCC(=O)O1</smiles>

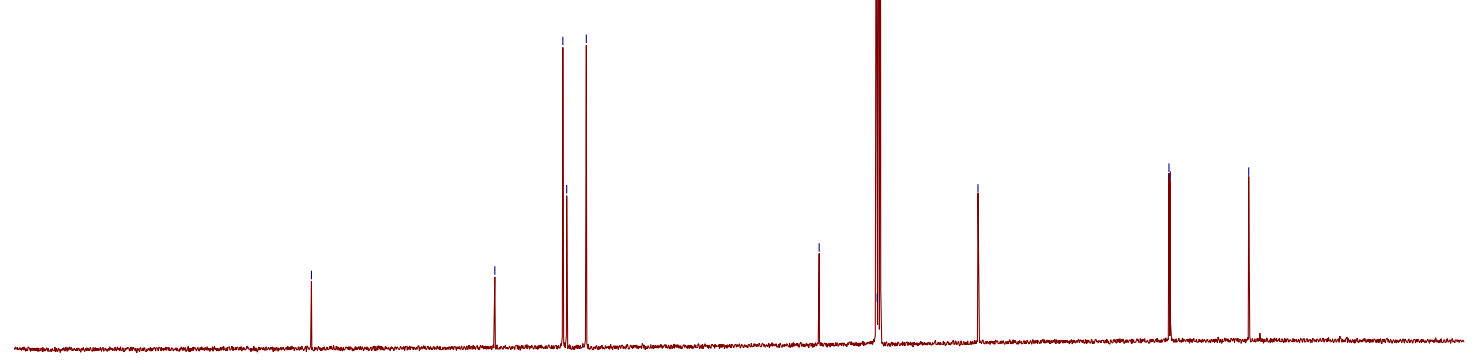


${ }^{1} \mathbf{H}$ NMR (400 MHz, $\mathrm{CDCl}_{3}$ ) of compound 6-(azidomethyl)-4,4-dimethyl-6-phenyltetrahydro2H-pyran-2-one (2p)

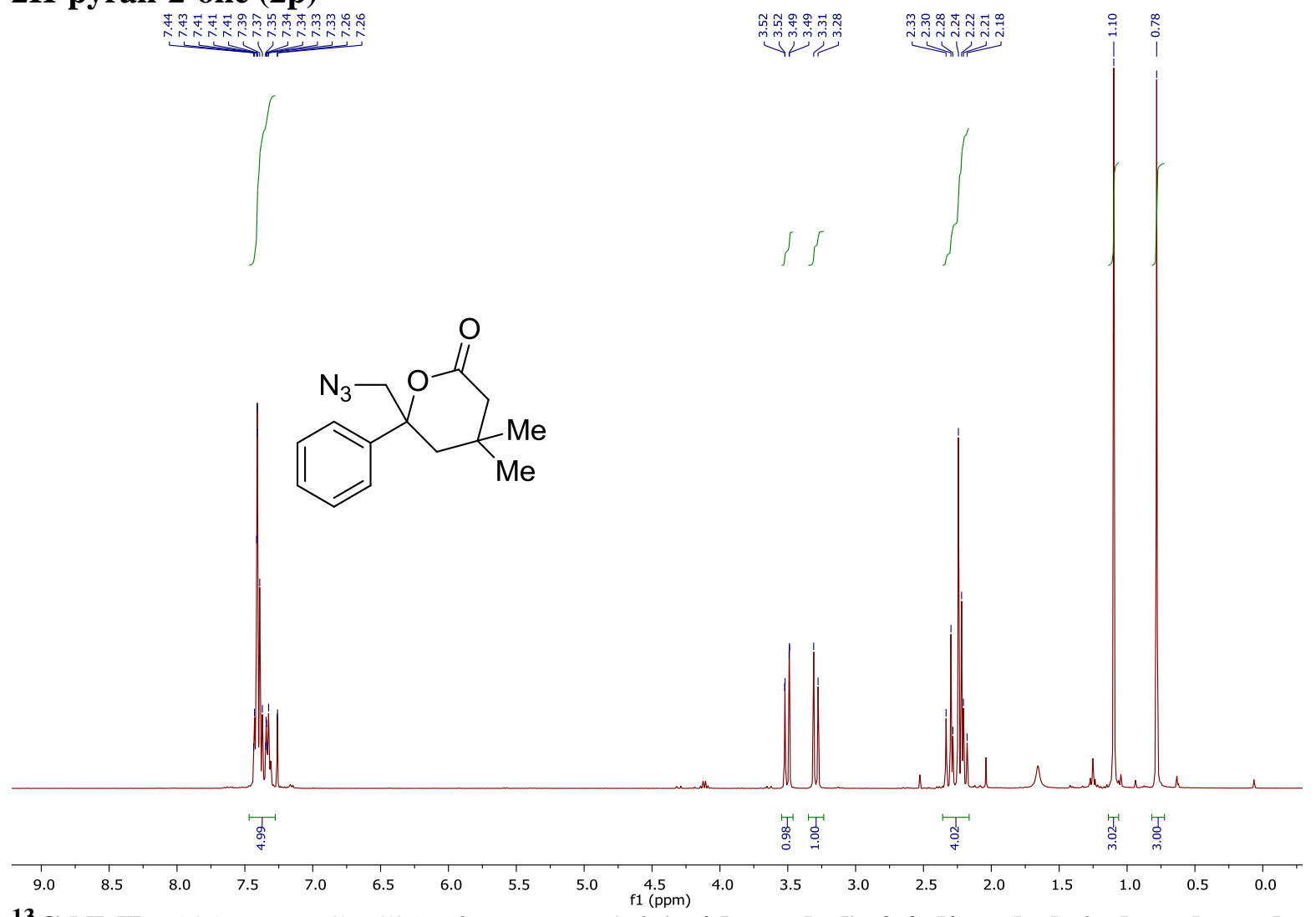

${ }^{13} \mathrm{C}$ NMR (101 MHz, $\mathrm{CDCl}_{3}$ ) of compound 6-(azidomethyl)-4,4-dimethyl-6-phenyltetrahydro2H-pyran-2-one (2p)

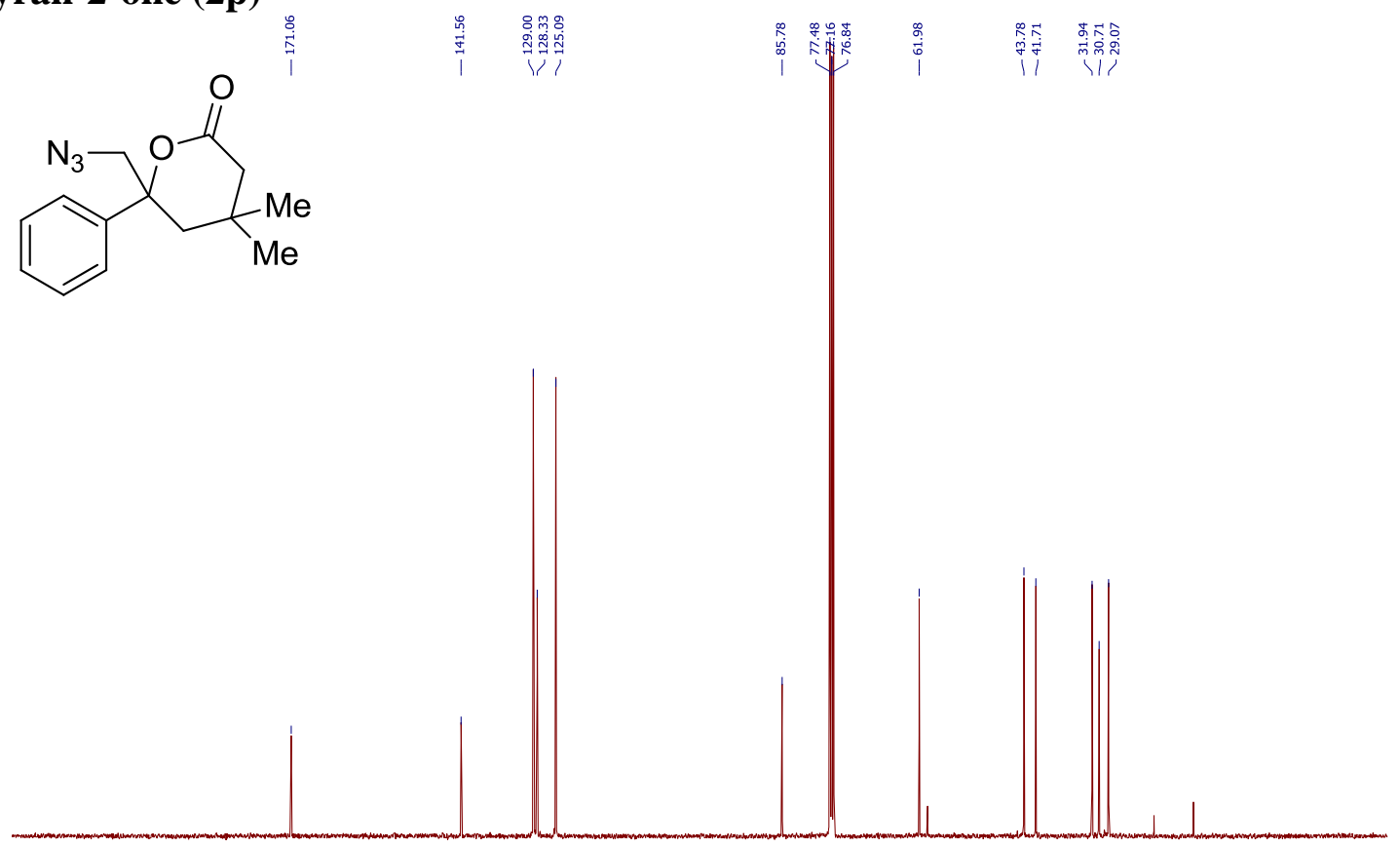

$\begin{array}{lllllllllllllllllllllll}210 & 200 & 190 & 180 & 170 & 160 & 150 & 140 & 130 & 120 & 110 & 100 & 90 & 80 & 70 & 60 & 50 & 40 & 30 & 20 & 10 & 0 & -10\end{array}$ 
${ }^{\mathbf{1}} \mathbf{H}$ NMR $\left(400 \mathrm{MHz}, \mathrm{CDCl}_{3}\right.$ ) of compound 6-(azidomethyl)-6-phenyl-1,4-dioxan-2-one (2q)

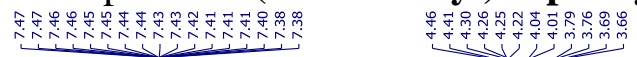

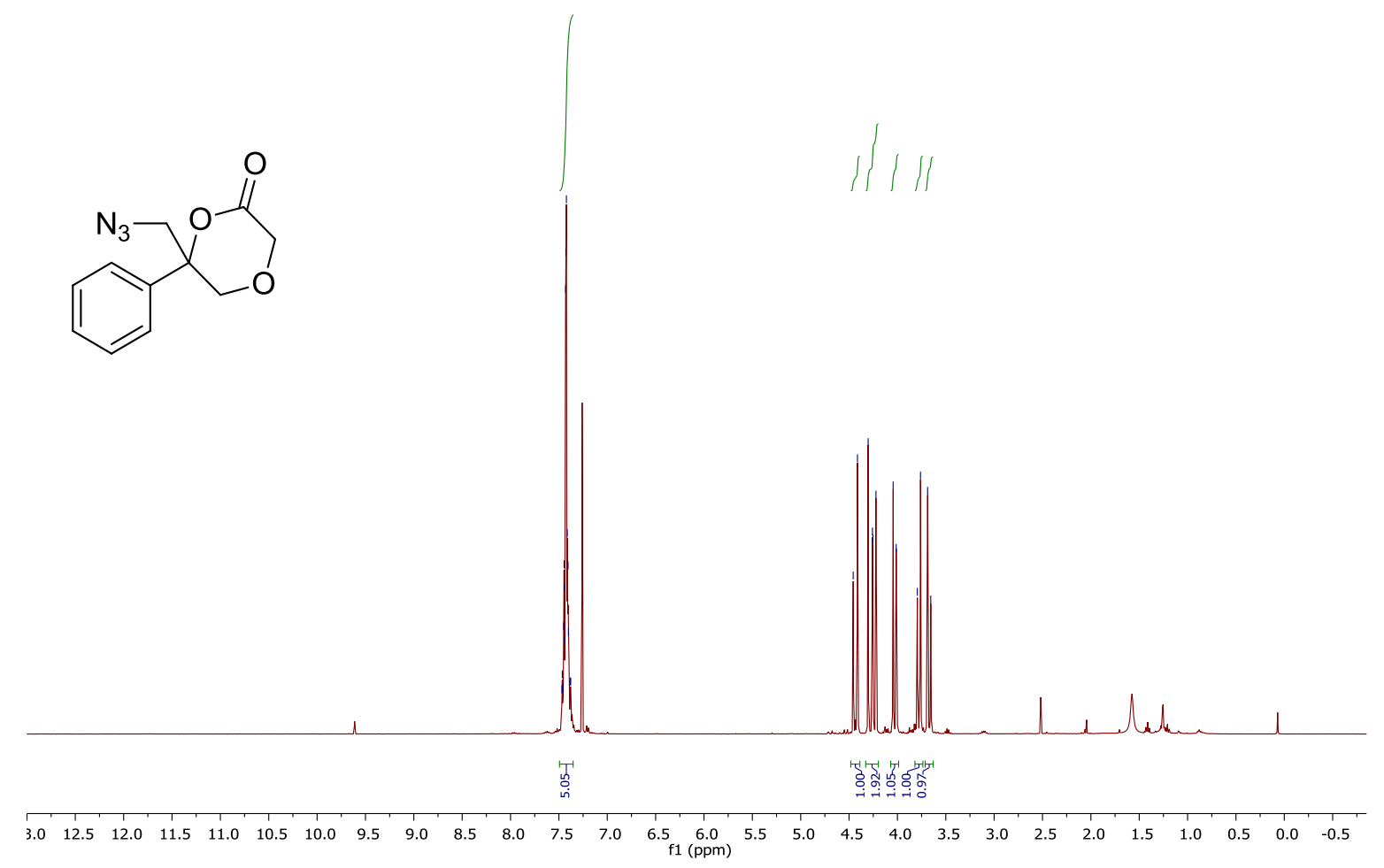

${ }^{13} \mathrm{C}$ NMR (101 MHz, $\mathrm{CDCl}_{3}$ ) of compound 6-(azidomethyl)-6-phenyl-1,4-dioxan-2-one (2q)

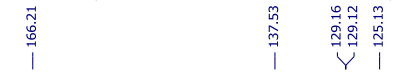<smiles>NCC1(c2ccccc2)COCC(=O)O1</smiles>
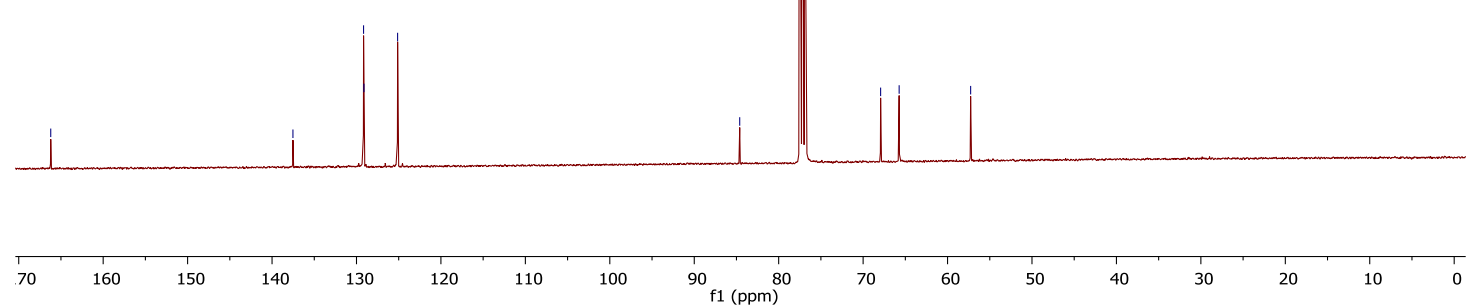
IR of compound 6-(azidomethyl)-6-phenyl-1,4-dioxan-2-one (2q)

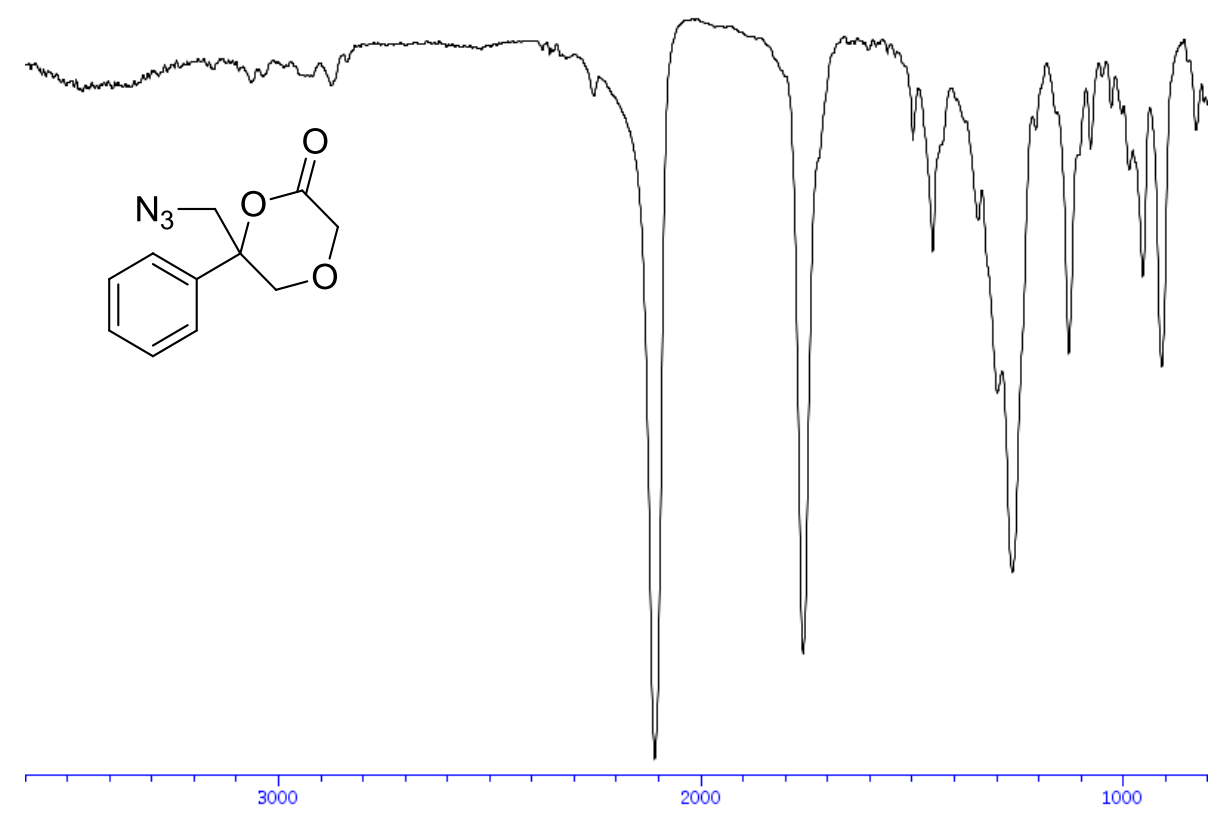


c. Spectra of new compounds for Lewis acid catalyzed aryl migration

${ }^{1}$ H-NMR (400 MHz, $\mathrm{CDCl}_{3}$ ) of compound 5-azido-5-benzyldihydrofuran-2(3H)-one (4a)

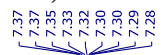

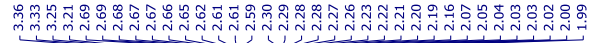<smiles>NC1(Cc2ccccc2)CCC(=O)O1</smiles>
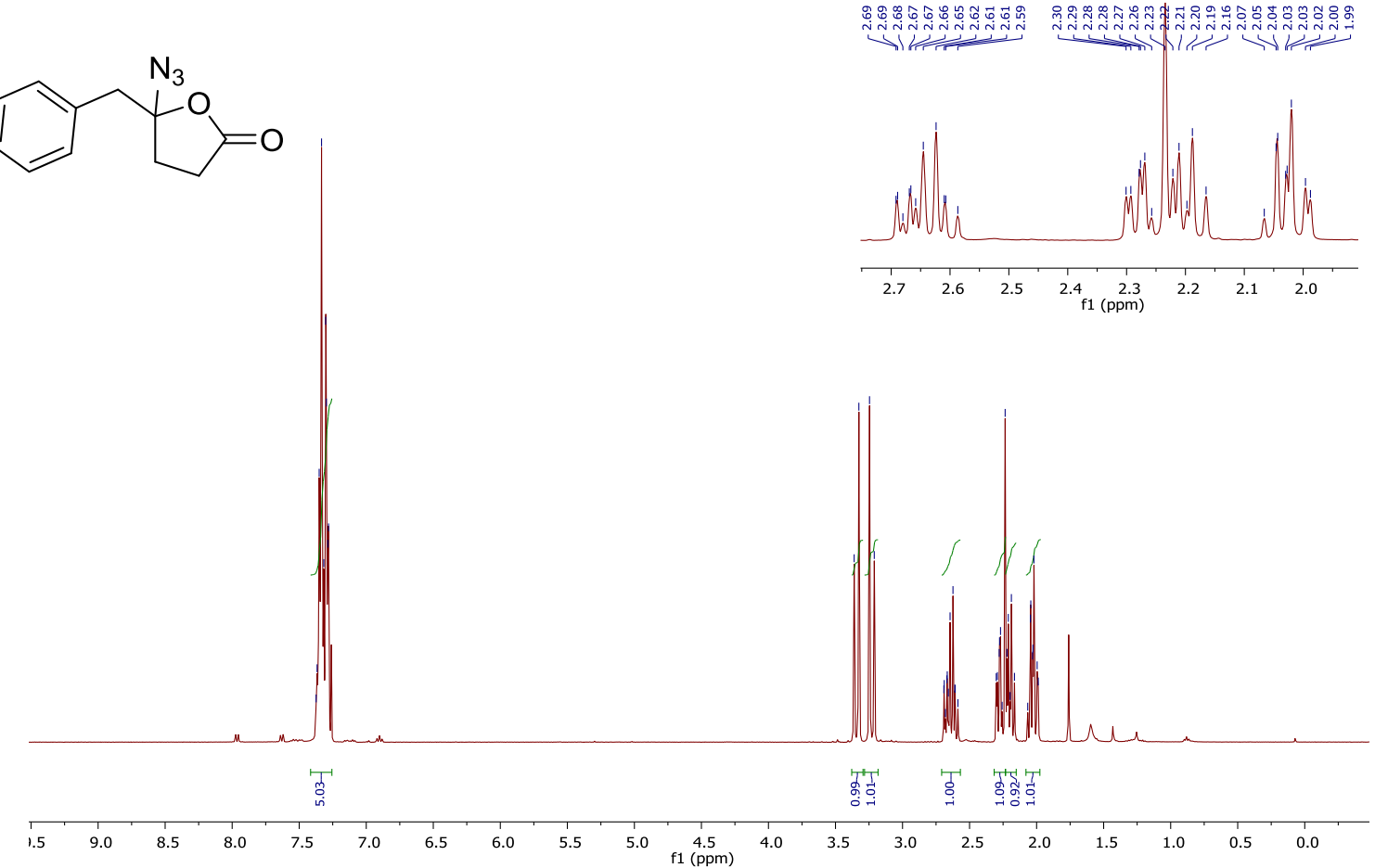

${ }^{13} \mathrm{C}$ NMR (101 MHz, $\left.\mathrm{CDCl}_{3}\right)$ of compound 5-azido-5-benzyldihydrofuran-2(3H)-one (4a)

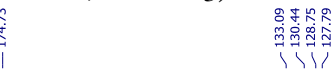
誉<smiles>NC1(Cc2ccccc2)CCC(=O)O1</smiles>
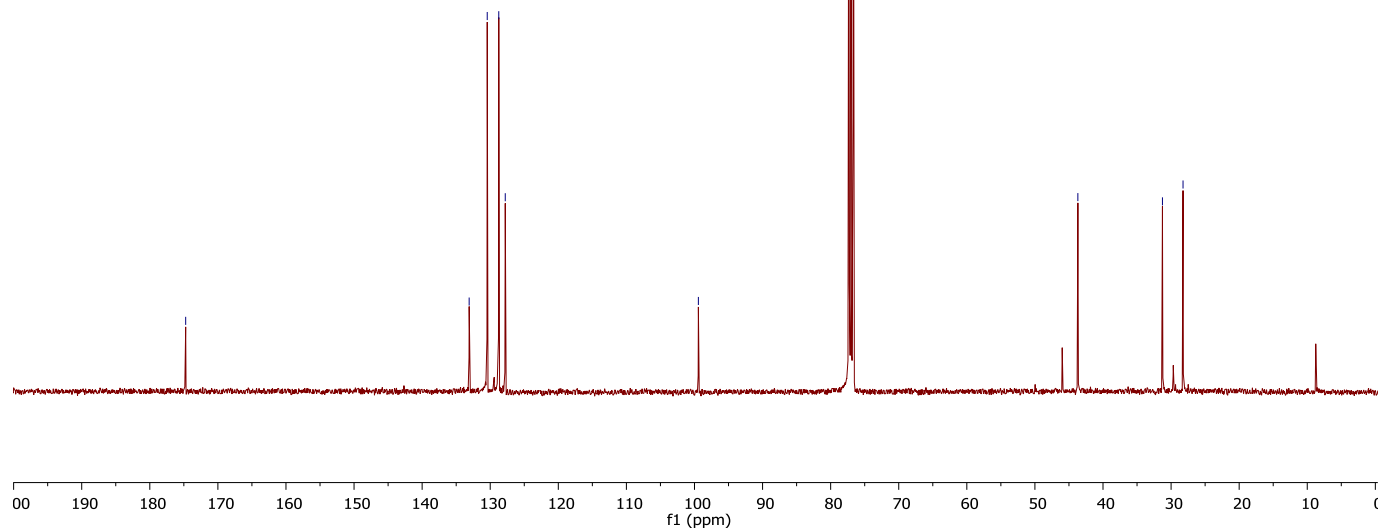

IR of compound 5-azido-5-benzyldihydrofuran-2(3H)-one (4a) 


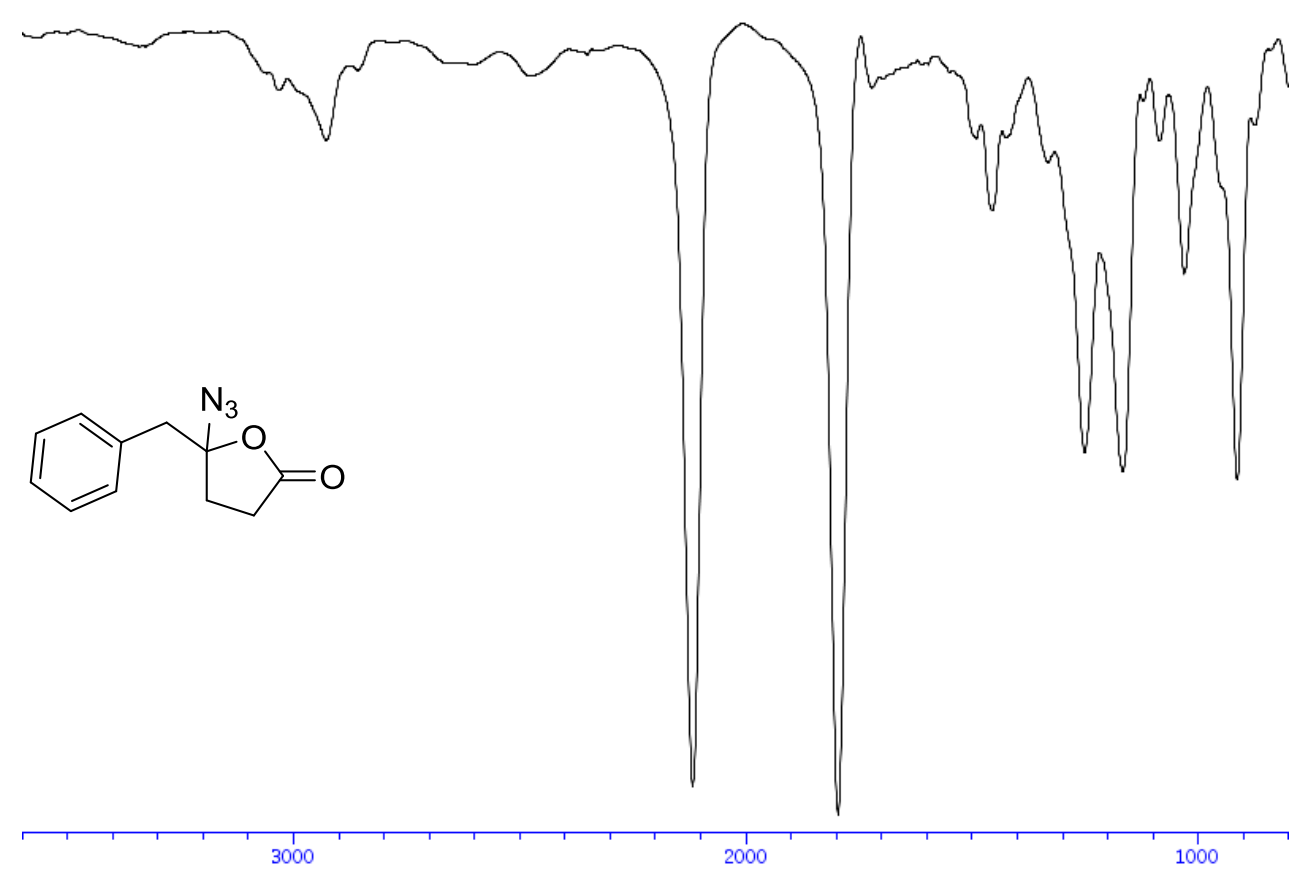

${ }^{1} \mathbf{H}$ NMR $\left(400 \mathrm{MHz}, \mathrm{CDCl}_{3}\right.$ ) of compound 5-azido-5-(4-bromobenzyl)dihydrofuran-2(3H)one (4b)
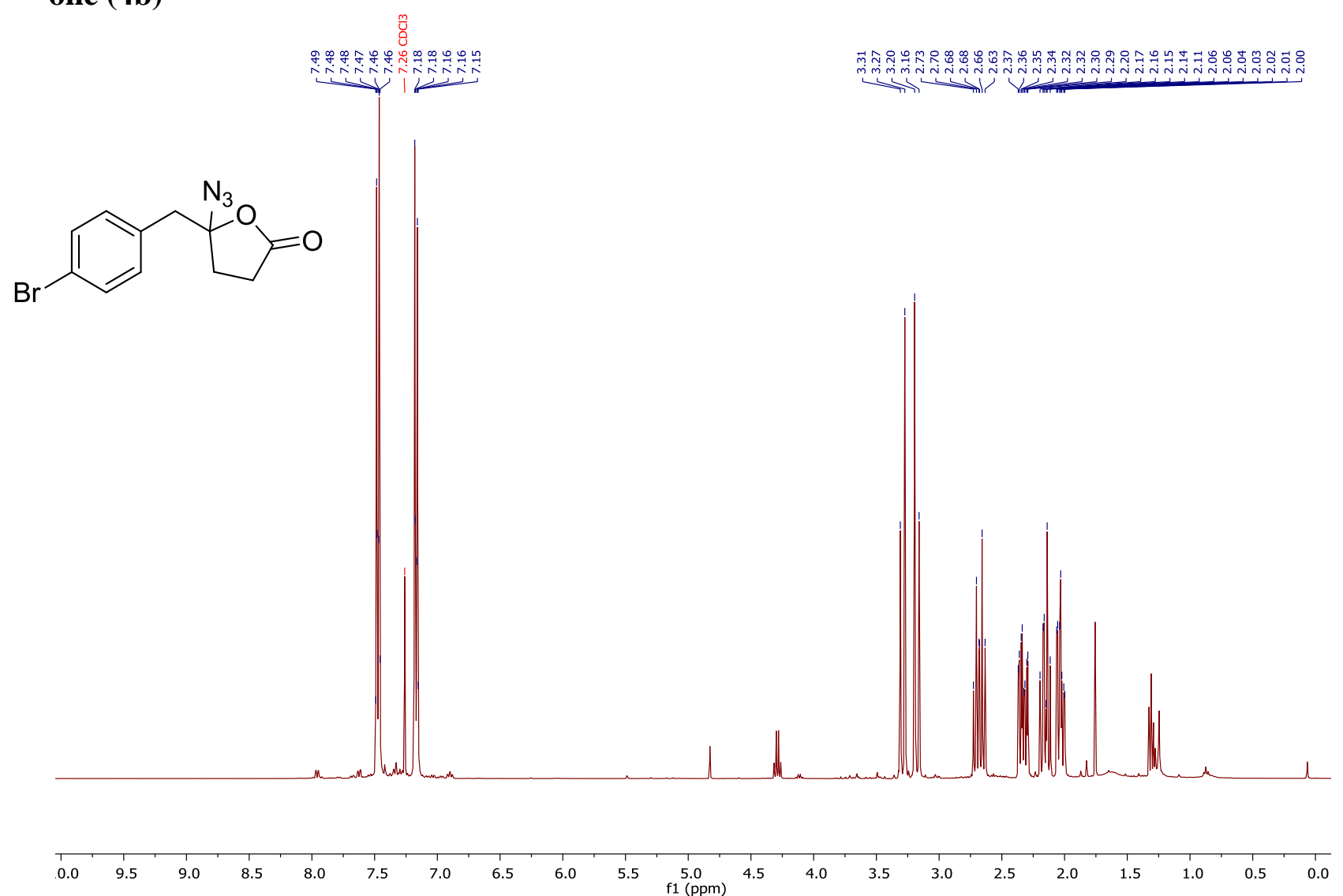
${ }^{13} \mathbf{C}$ NMR $\left(101 \mathrm{MHz}, \mathrm{CDCl}_{3}\right)$ of compound 5-azido-5-(4-bromobenzyl)dihydrofuran-2(3H)one (4b)

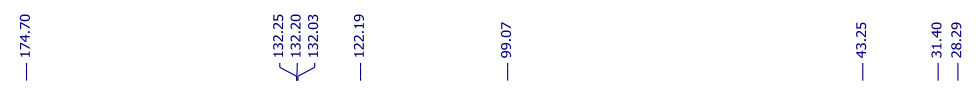<smiles>NC1(Cc2ccc(Br)cc2)CCC(=O)O1</smiles>
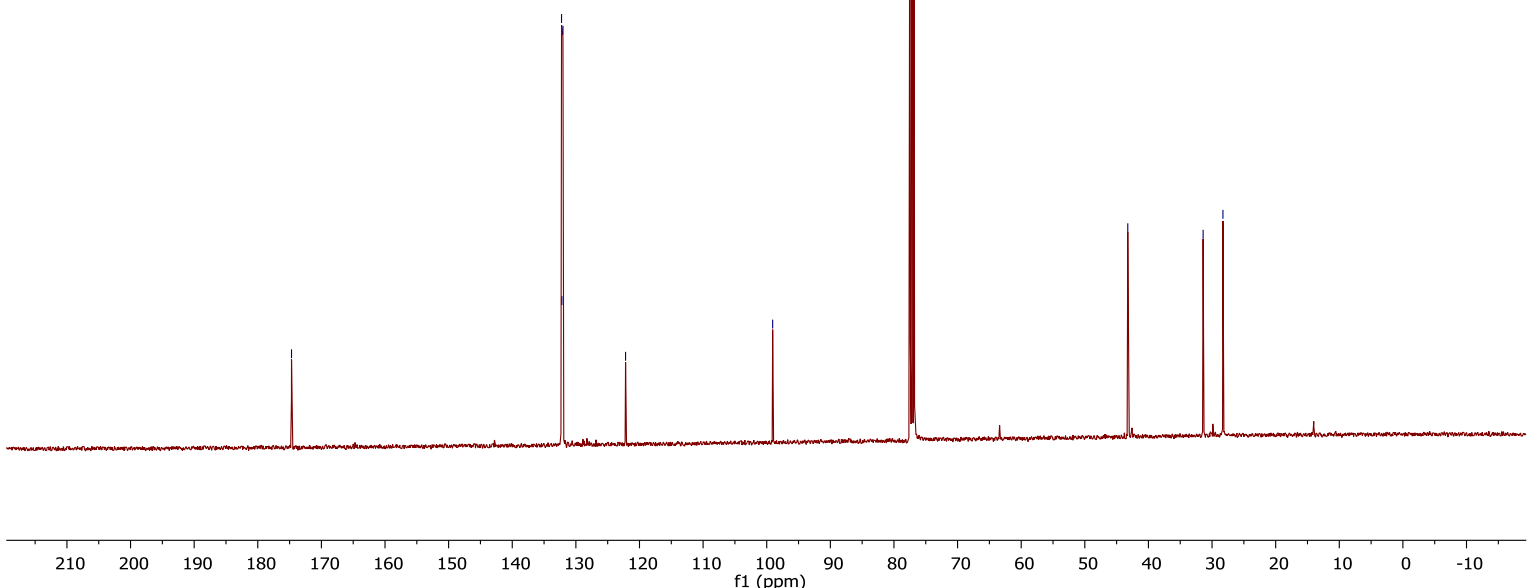

IR of compound 5-azido-5-(4-bromobenzyl)dihydrofuran-2(3H)-one (4b)

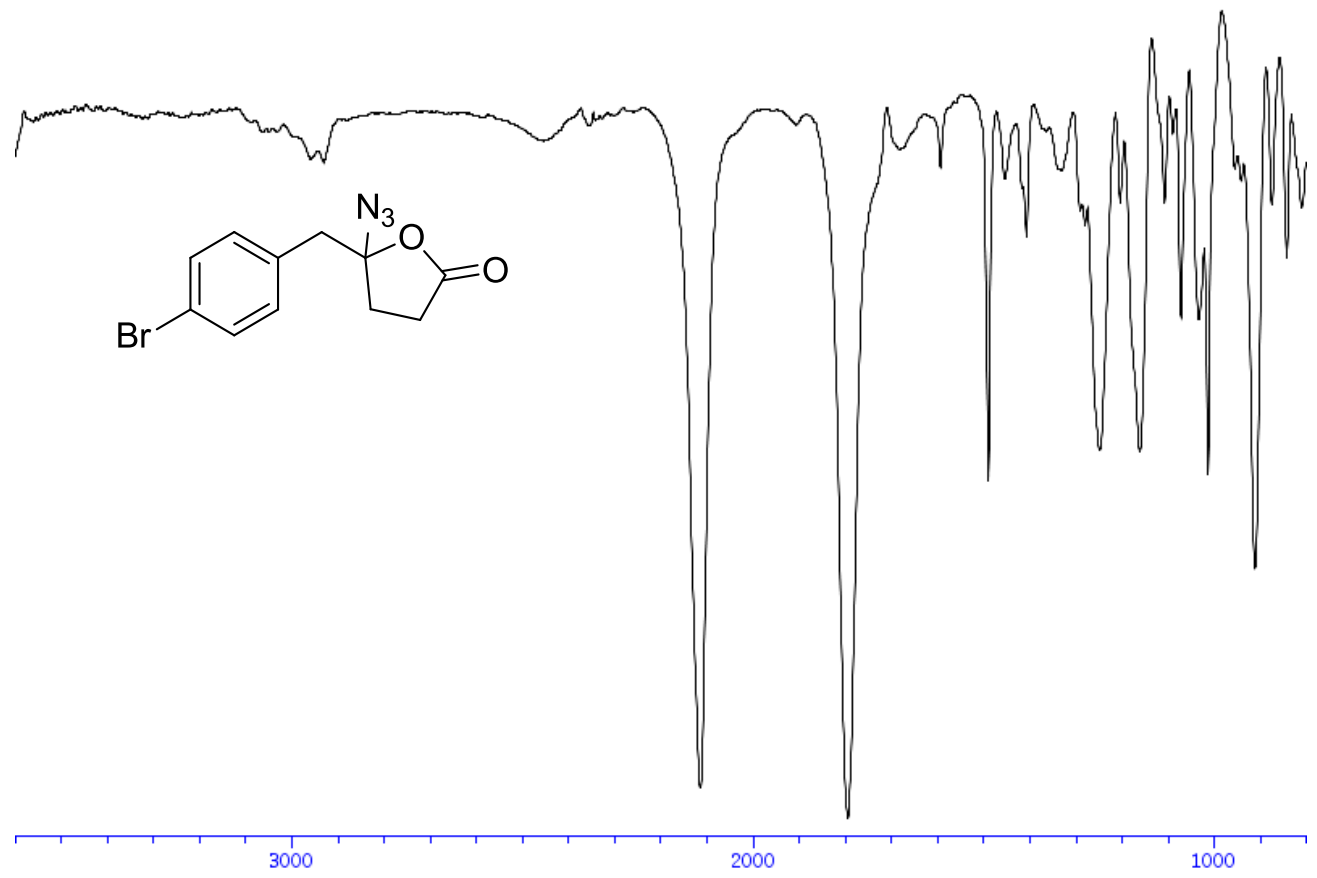


${ }^{1} \mathbf{H}$ NMR (400 MHz, $\mathrm{CDCl}_{3}$ ) of compound 5-azido-5-(4-fluorobenzyl)dihydrofuran-2(3H)-one (4c)

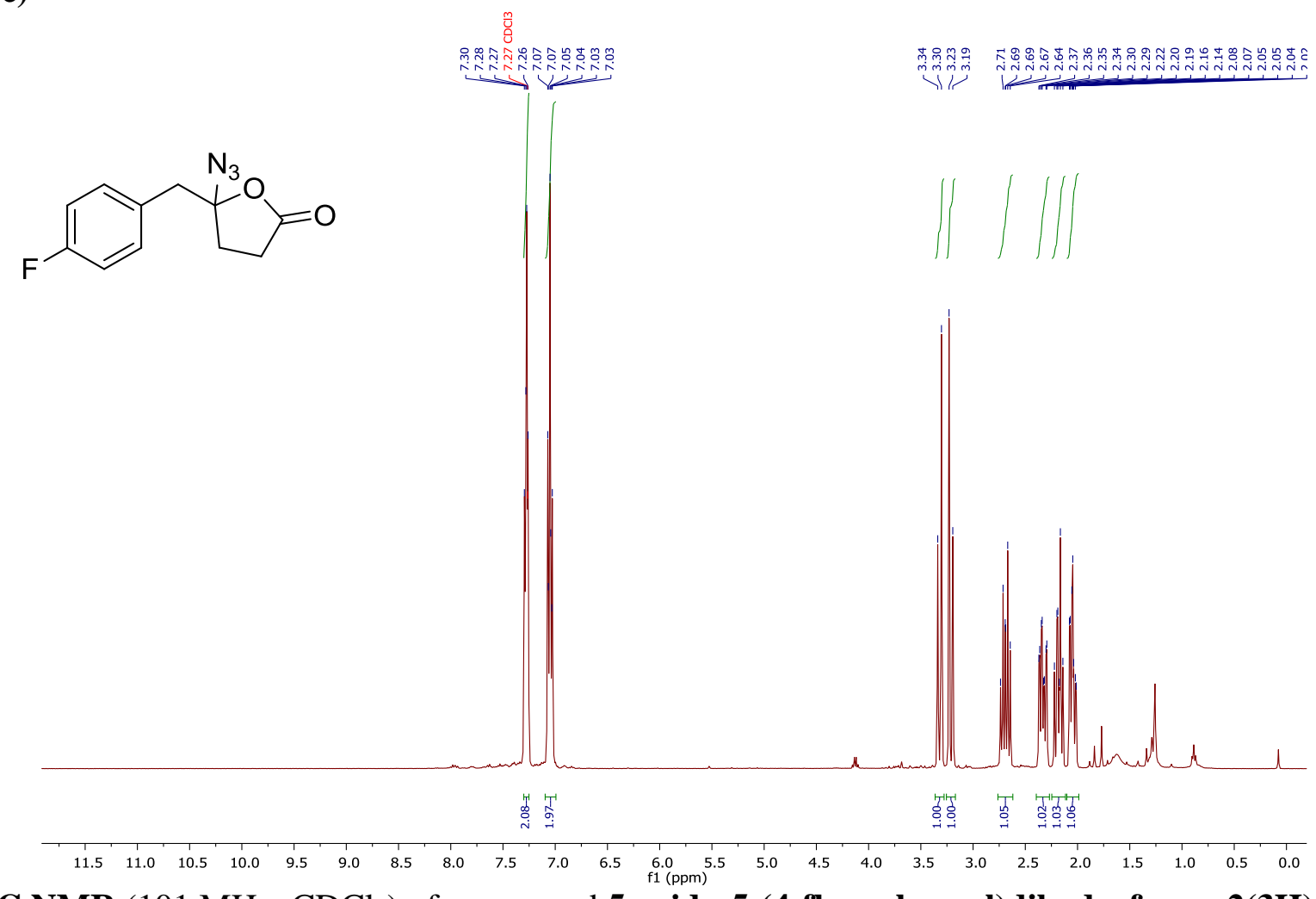

${ }^{13} \mathbf{C ~ N M R ~ ( 1 0 1 ~ M H z , ~} \mathrm{CDCl}_{3}$ ) of compound 5-azido-5-(4-fluorobenzyl)dihydrofuran-2(3H)one (4c)
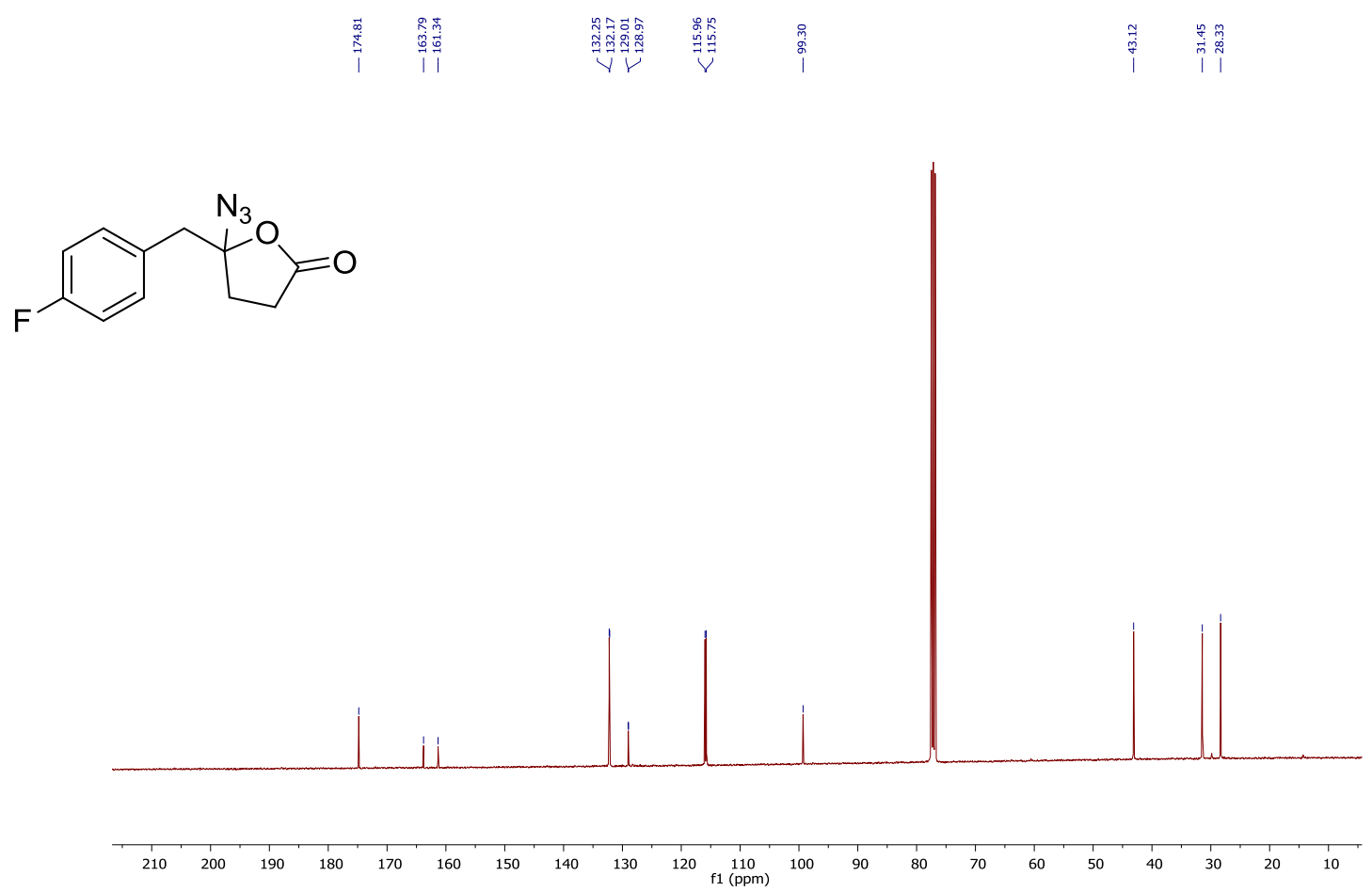
${ }^{19}$ F NMR $\left(376 \mathrm{MHz}, \mathrm{CDCl}_{3}\right)$ of compound 5-azido-5-(4-fluorobenzyl)dihydrofuran-2(3H)-one (4c)
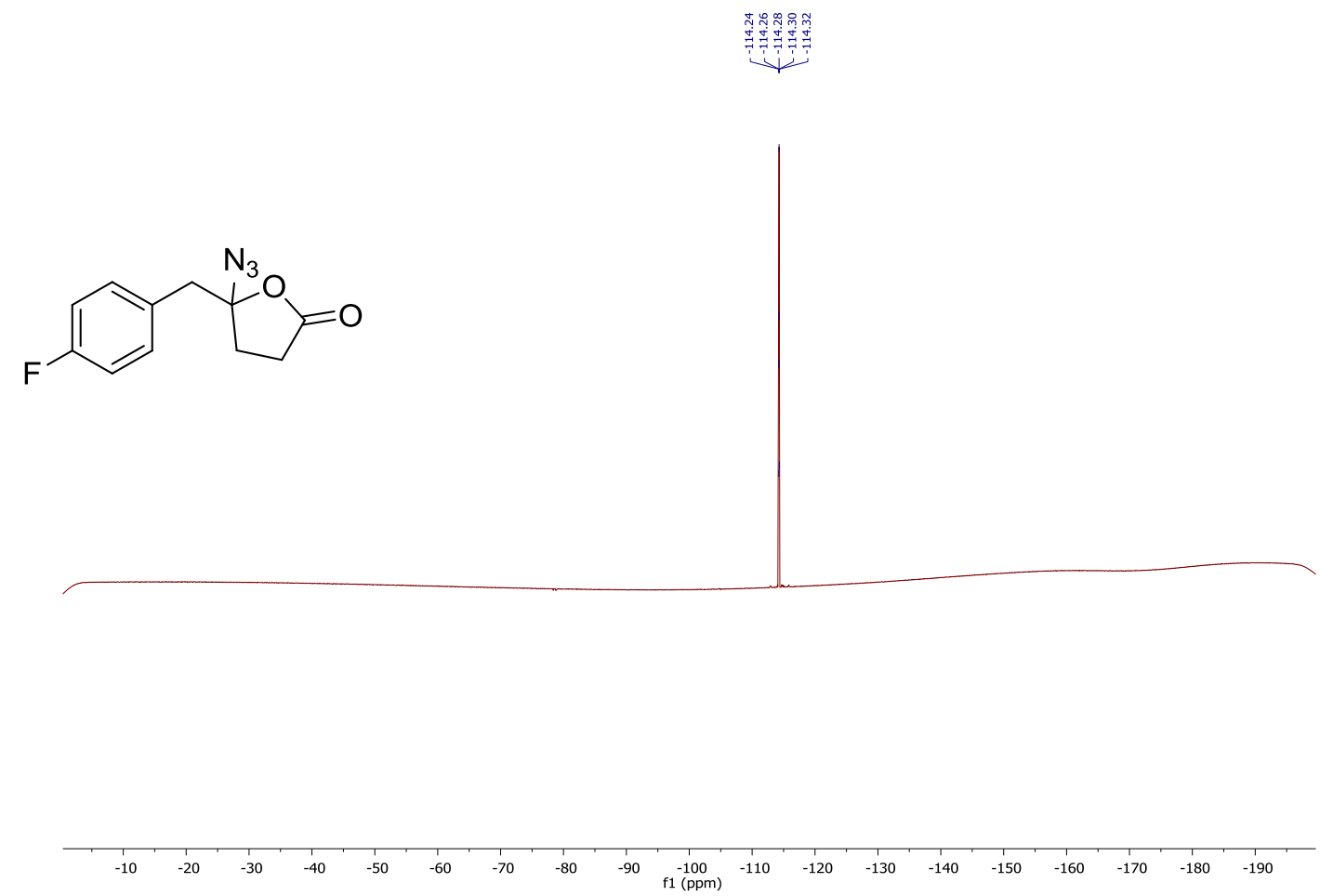

IR of compound 5-azido-5-(4-fluorobenzyl)dihydrofuran-2(3H)-one (4c)

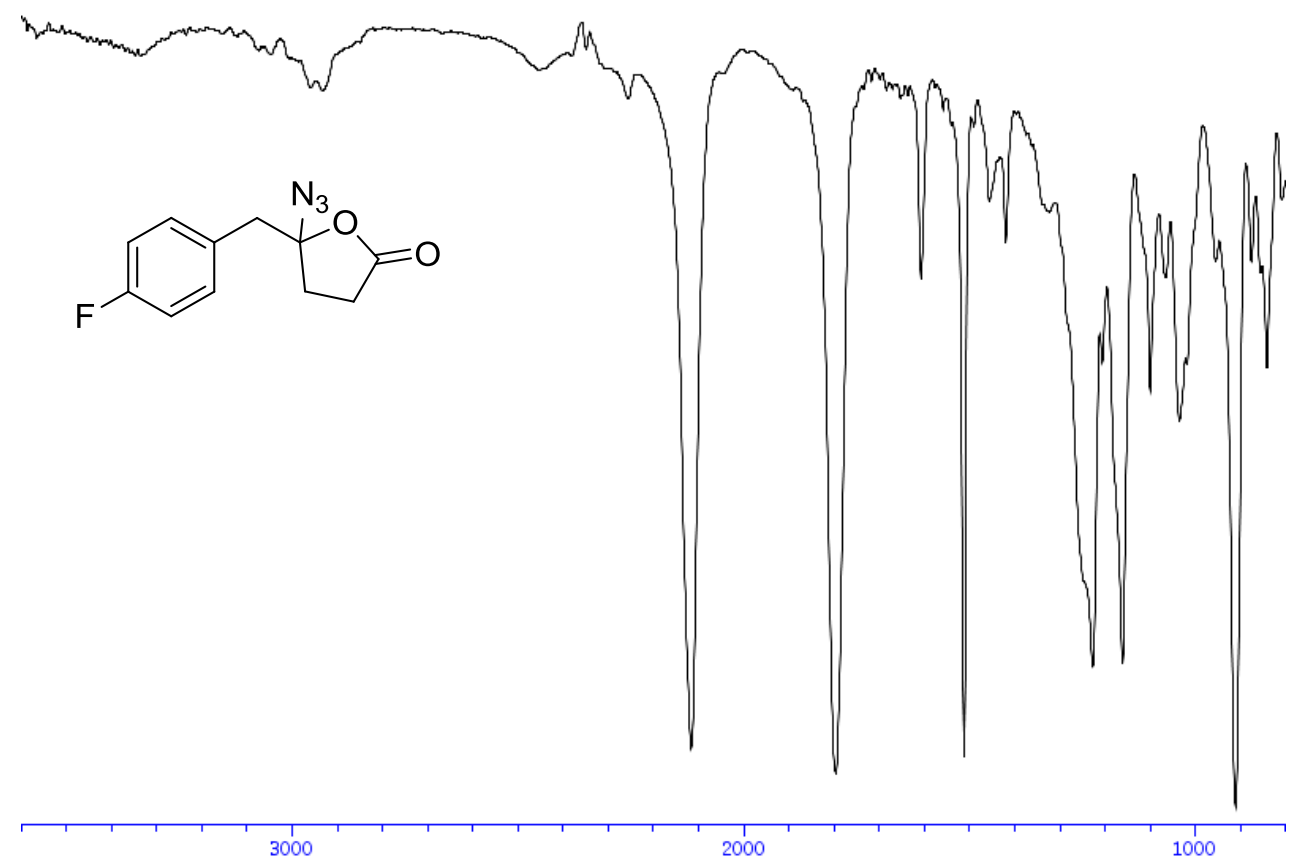


${ }^{\mathbf{1}} \mathbf{H}$ NMR (400 MHz, $\mathrm{CDCl}_{3}$ ) of compound 5-azido-5-(4-chlorobenzyl)dihydrofuran-2(3H)-one (4d)
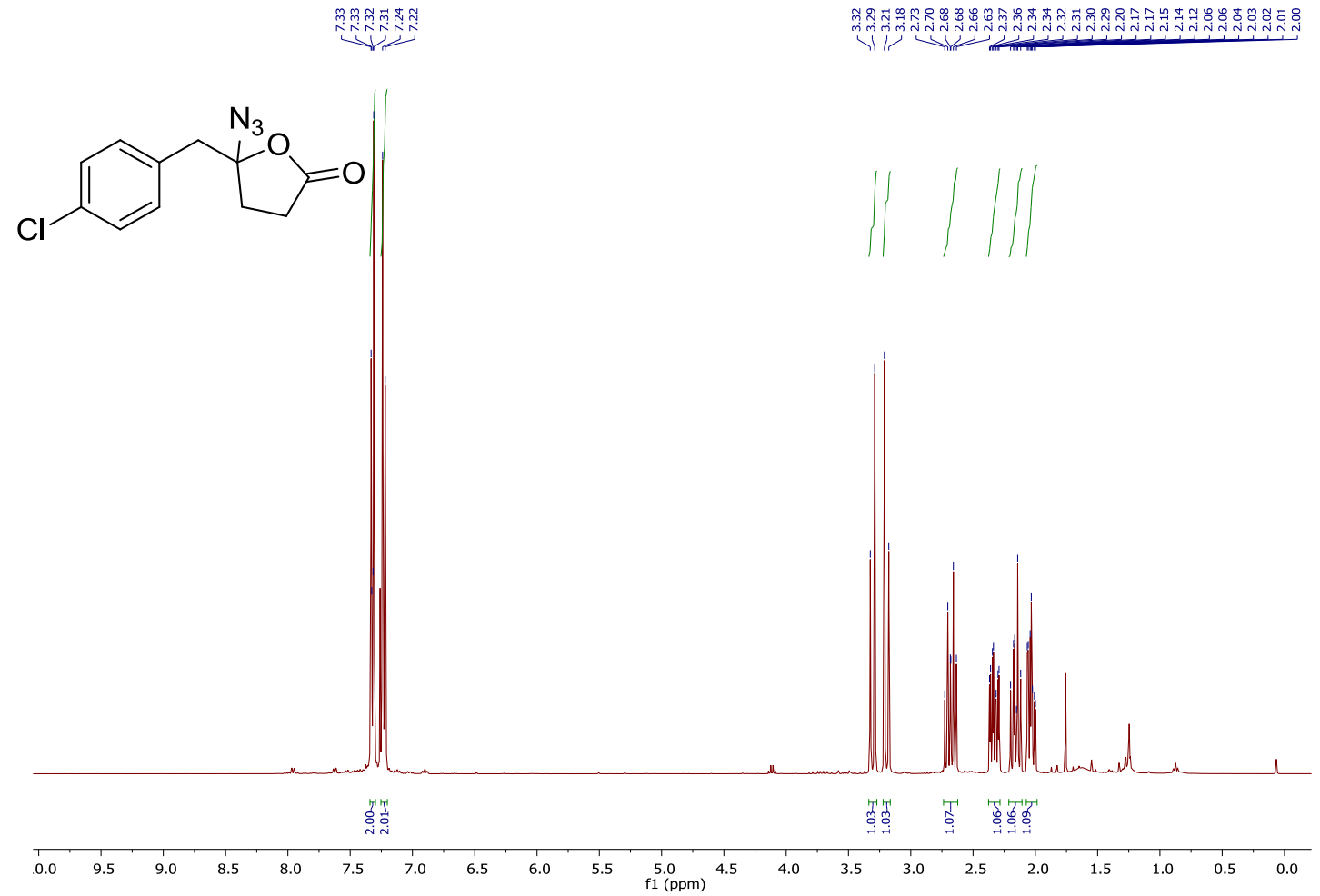

${ }^{13}$ C NMR (101 MHz, $\mathrm{CDCl}_{3}$ ) of compound 5-azido-5-(4-chlorobenzyl)dihydrofuran-2(3H)one (4d)

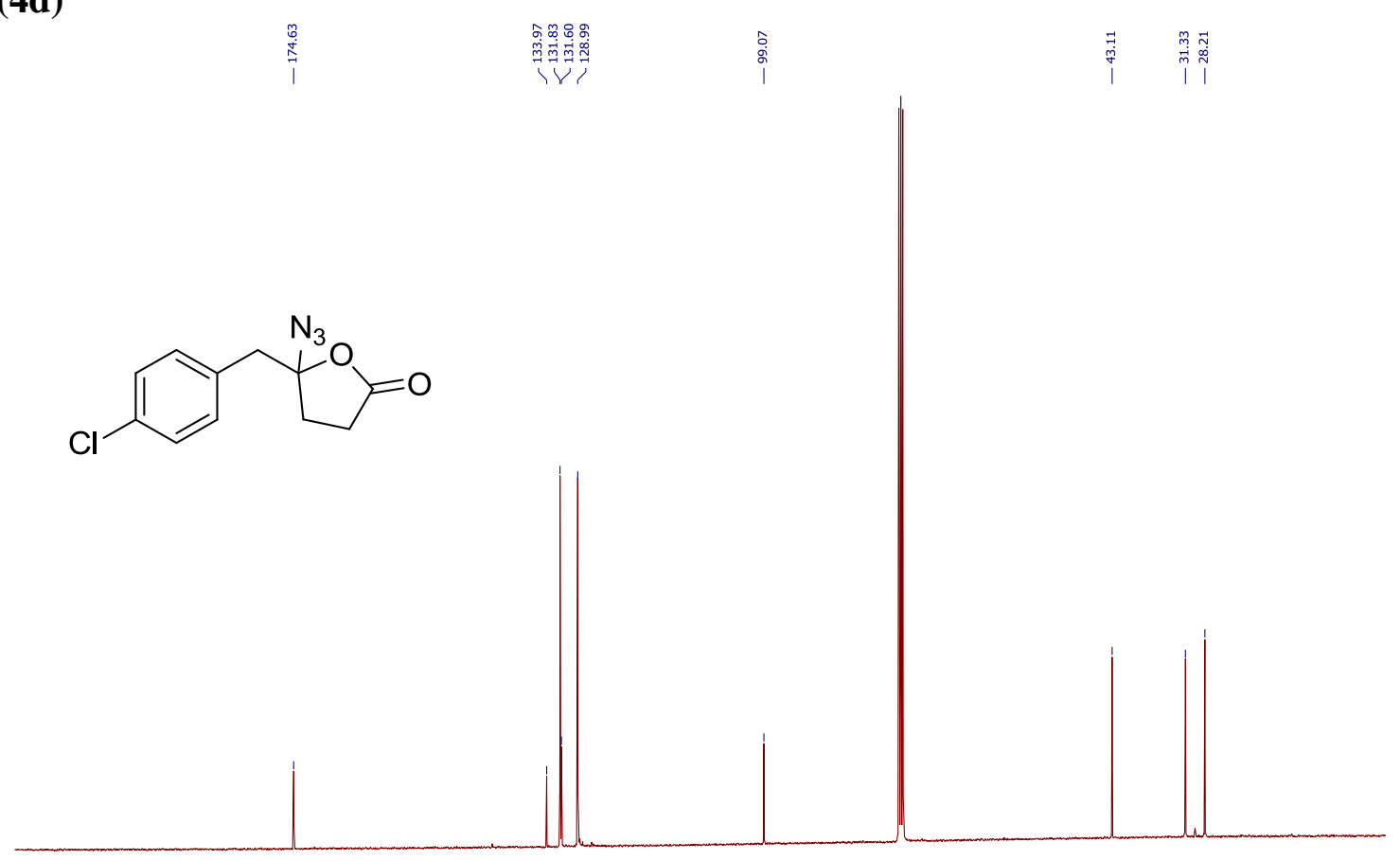

$\begin{array}{llllllllllllllllllllllllll}210 & 200 & 190 & 180 & 170 & 160 & 150 & 140 & 130 & 120 & 110 & 100 & 90 & 80 & 70 & 60 & 50 & 40 & 30 & 20 & 10 & \mathrm{C}\end{array}$ 
IR of compound 5-azido-5-(4-chlorobenzyl)dihydrofuran-2(3H)-one (4d)

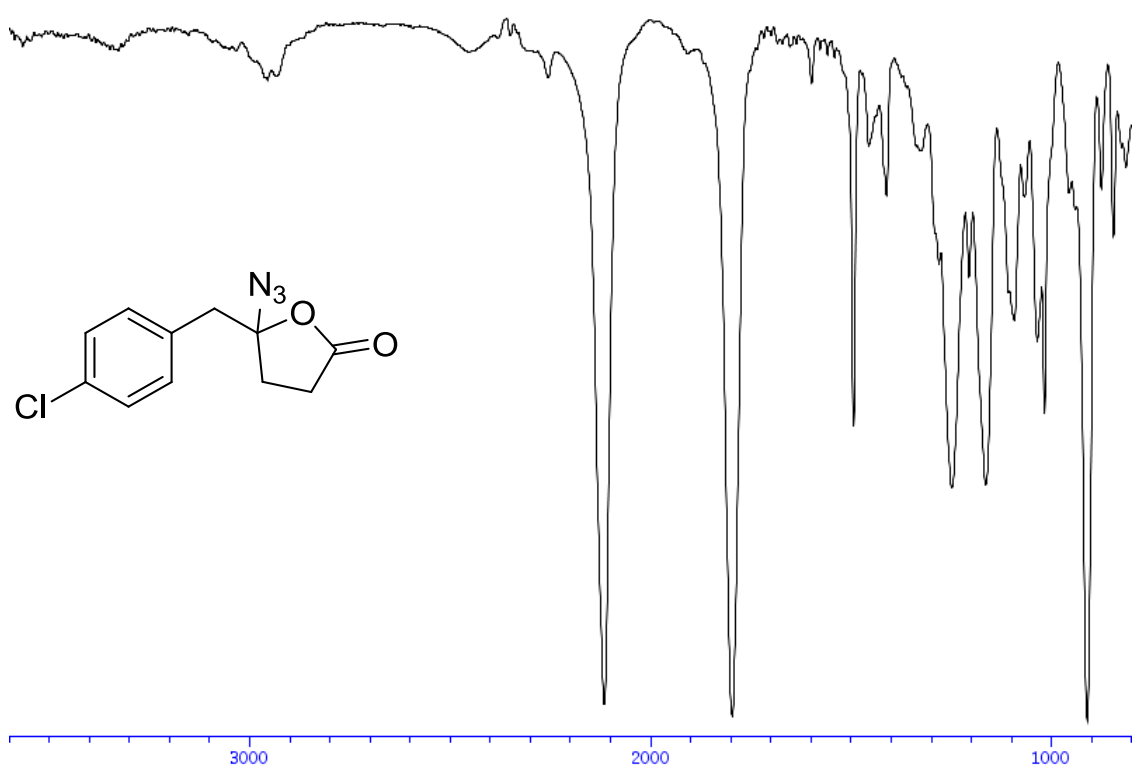

${ }^{1}$ H NMR (400 MHz, $\mathrm{CDCl}_{3}$ ) of compound 5-azido-5-(4-methylbenzyl)dihydrofuran-2(3H)one (4e)

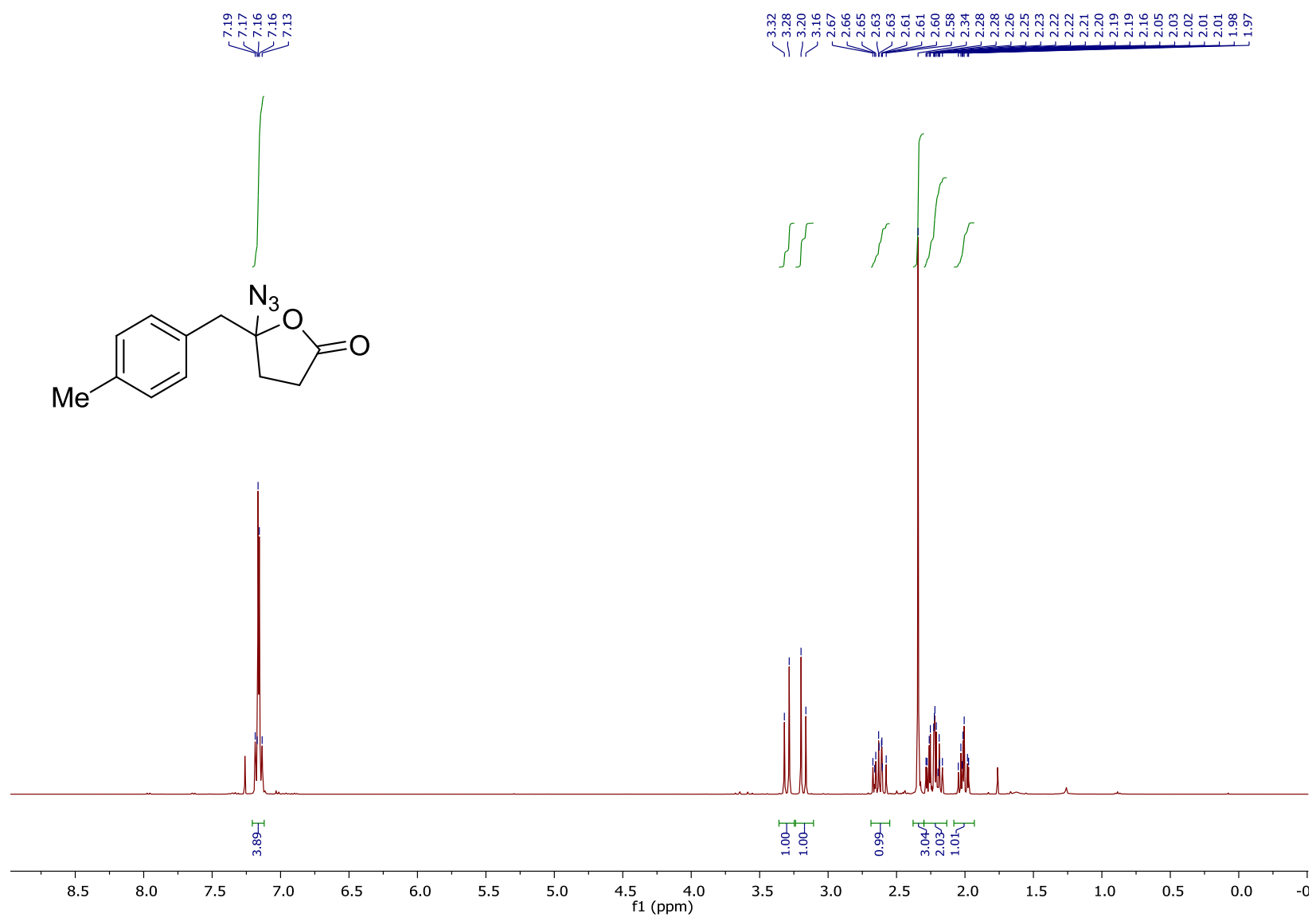


${ }^{13} \mathrm{C}$ NMR (101 MHz, $\mathrm{CDCl}_{3}$ ) of compound 5-azido-5-(4-methylbenzyl)dihydrofuran-2(3H)one (4e)

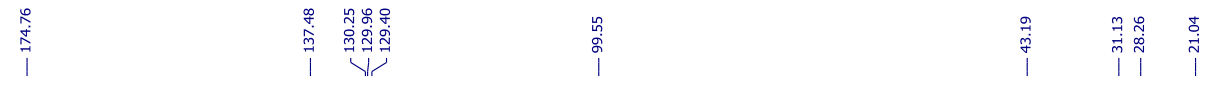<smiles>Cc1ccc(CC2(N)CCC(=O)O2)cc1</smiles>
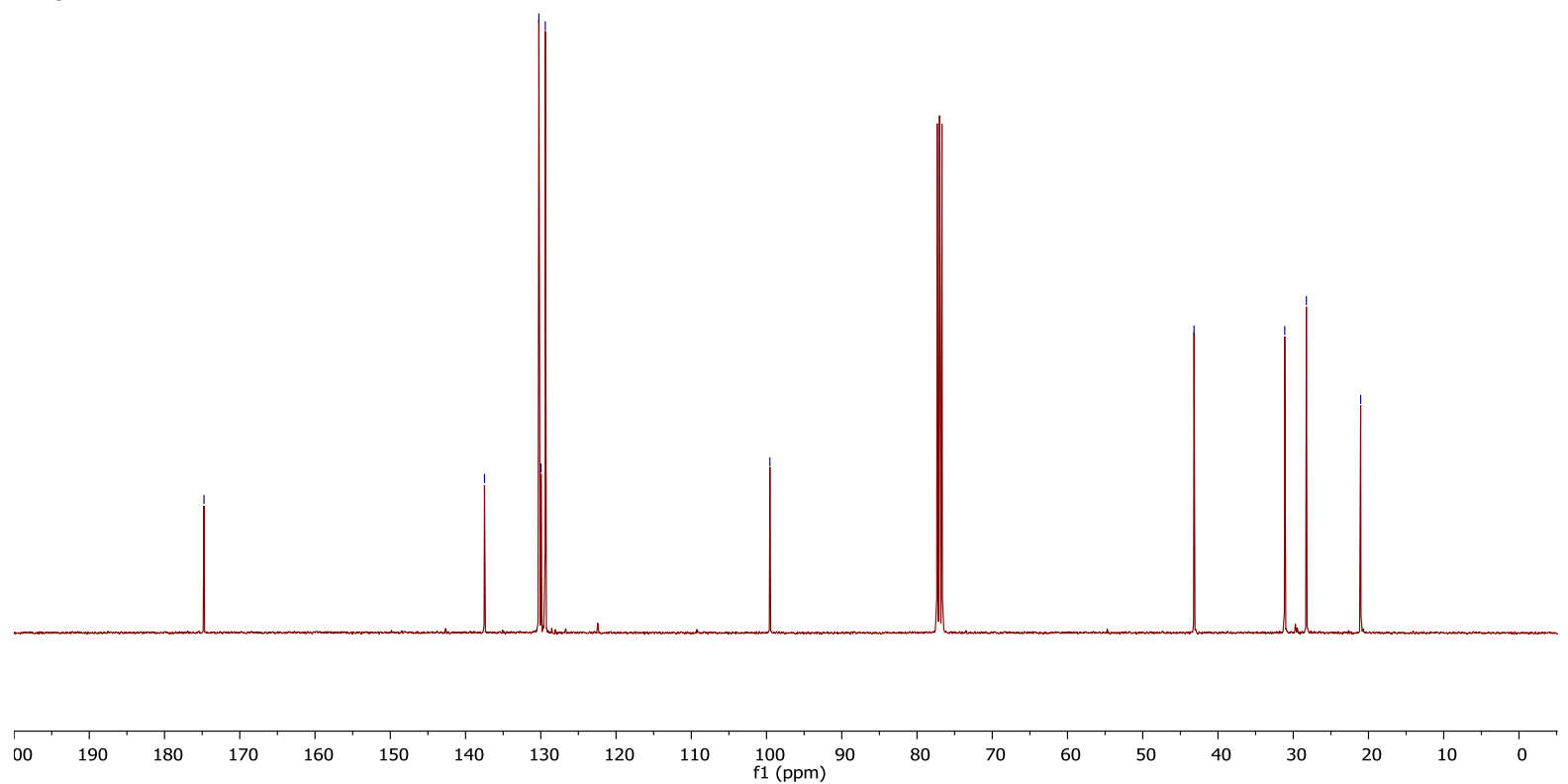

IR of compound 5-azido-5-(4-methylbenzyl)dihydrofuran-2(3H)-one (4e)

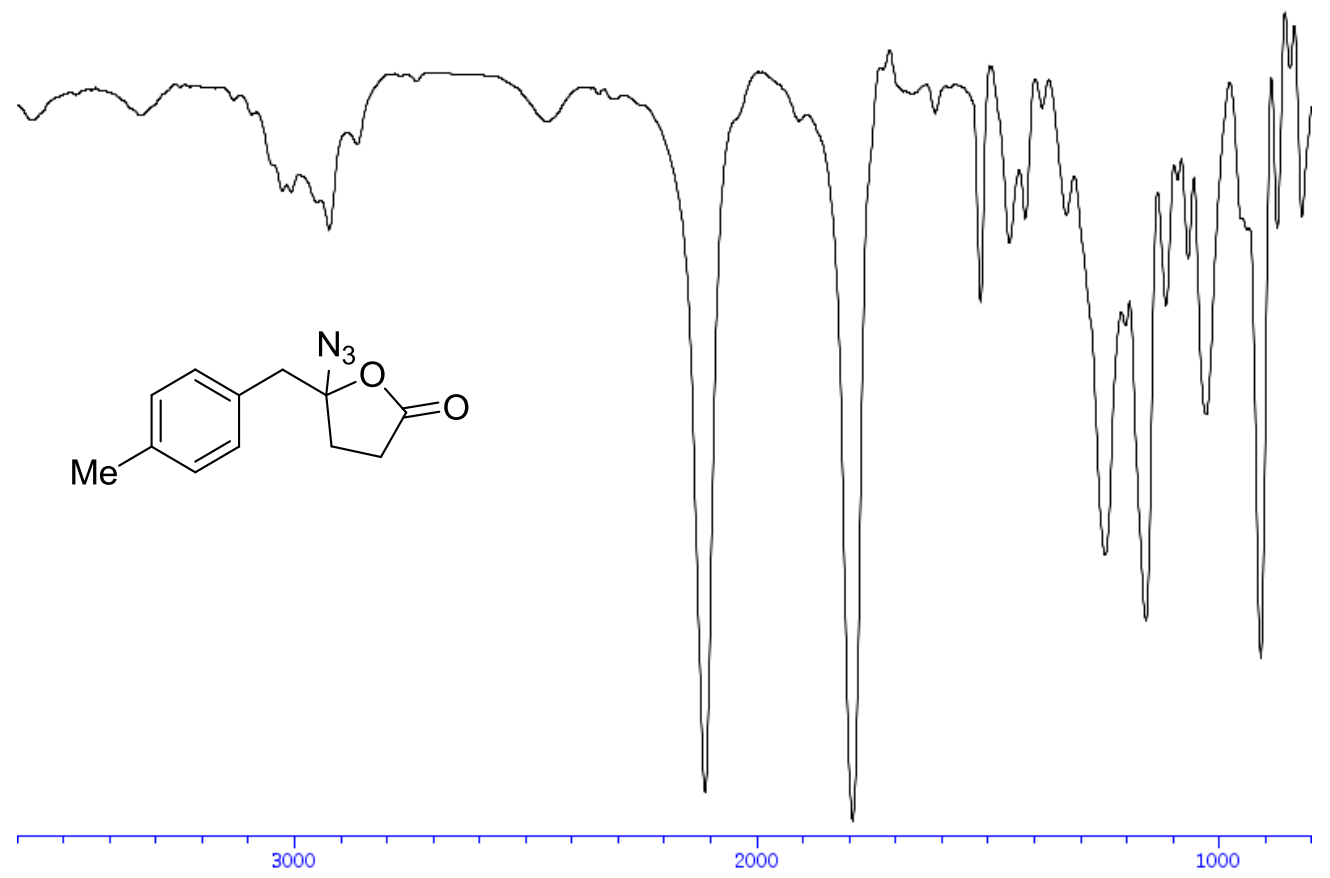


${ }^{1} \mathbf{H}$ NMR (400 MHz, $\mathrm{CDCl}_{3}$ ) of compound 5-azido-5-(2,5-dimethylbenzyl)dihydrofuran2(3H)-one (4f)

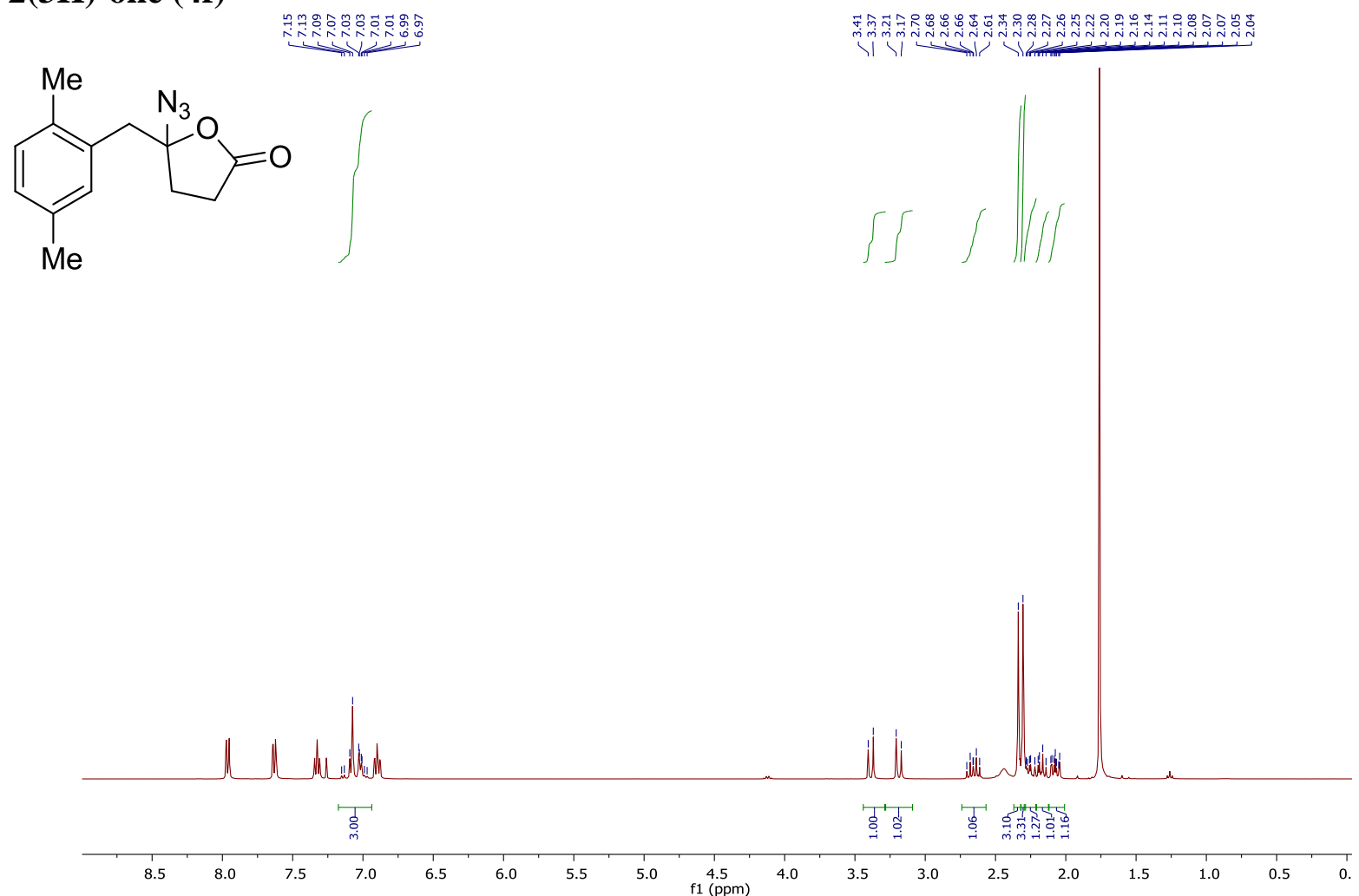

${ }^{1} \mathbf{H}$ NMR (400 MHz, $\mathrm{CDCl}_{3}$ ) of compound 2-(2-iodophenyl)propan-2-ol $\underbrace{4} \underbrace{2}$

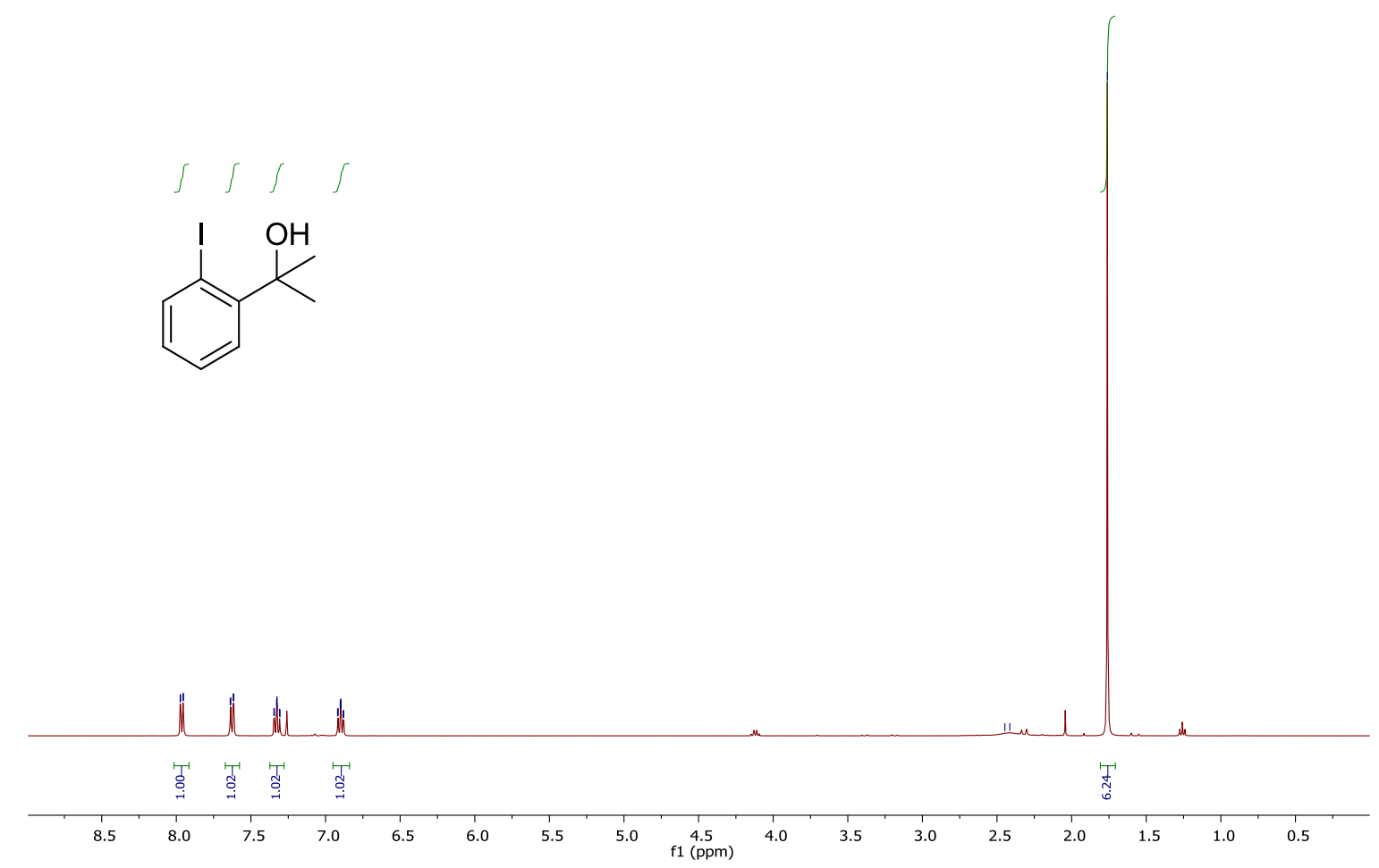


${ }^{13} \mathrm{C}$ NMR (101 MHz, $\mathrm{CDCl}_{3}$ ) of compound 5-azido-5-(2,5-dimethylbenzyl)dihydrofuran2(3H)-one (4f)

交

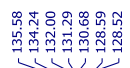

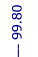

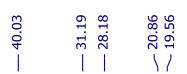

$\underbrace{\mathrm{Me}}_{\mathrm{Me}}=0$
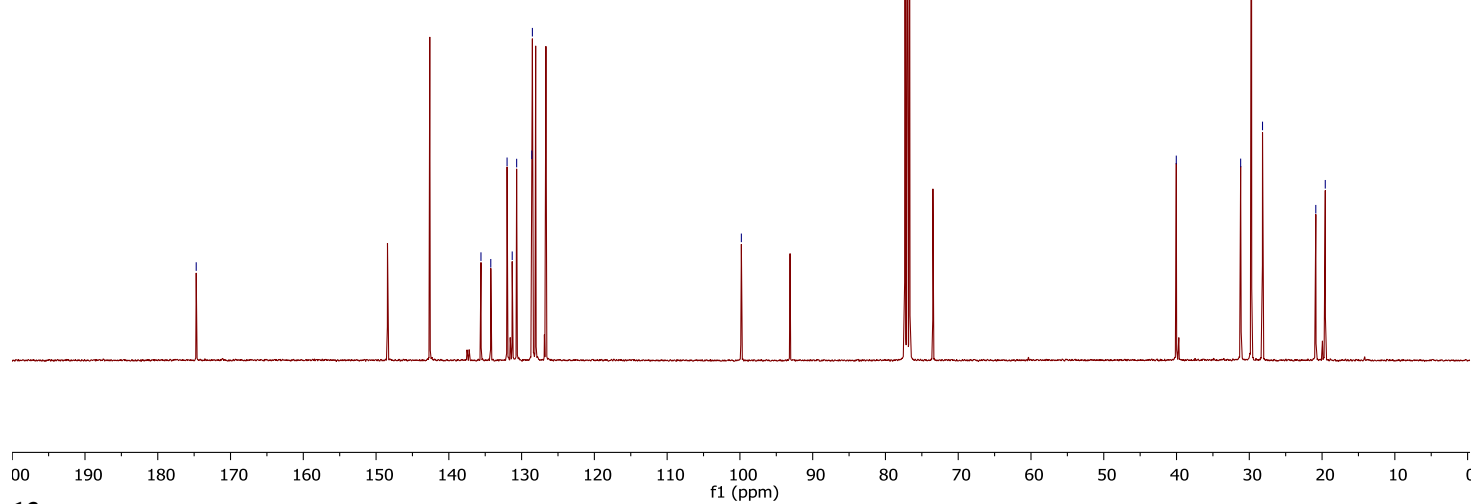

${ }^{13} \mathrm{C}$ NMR (101 MHz, $\mathrm{CDCl}_{3}$ ) of compound 2-(2-iodophenyl)propan-2-ol
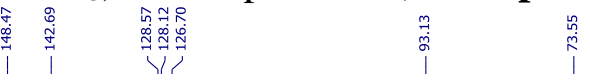<smiles>CC(C)(O)c1ccccc1I</smiles>

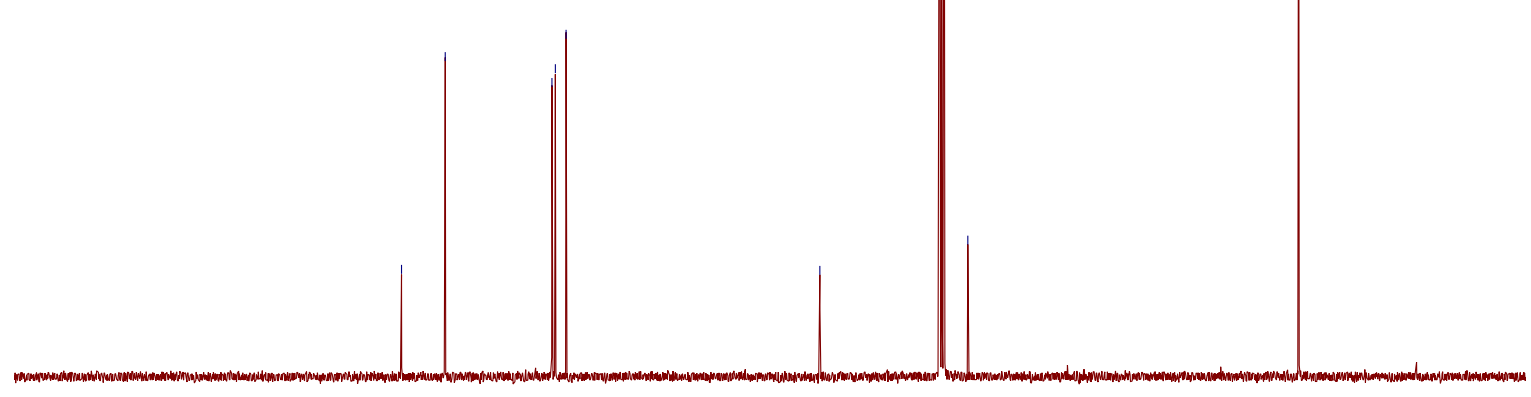

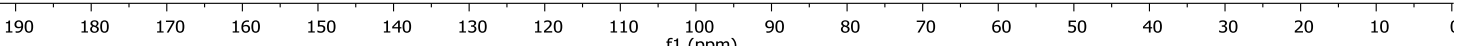


${ }^{1}$ H-NMR (400 MHz, $\mathrm{CDCl}_{3}$ ) of compound 5-azido-5-(thiophen-3-ylmethyl)dihydrofuran2(3H)-one (4g)
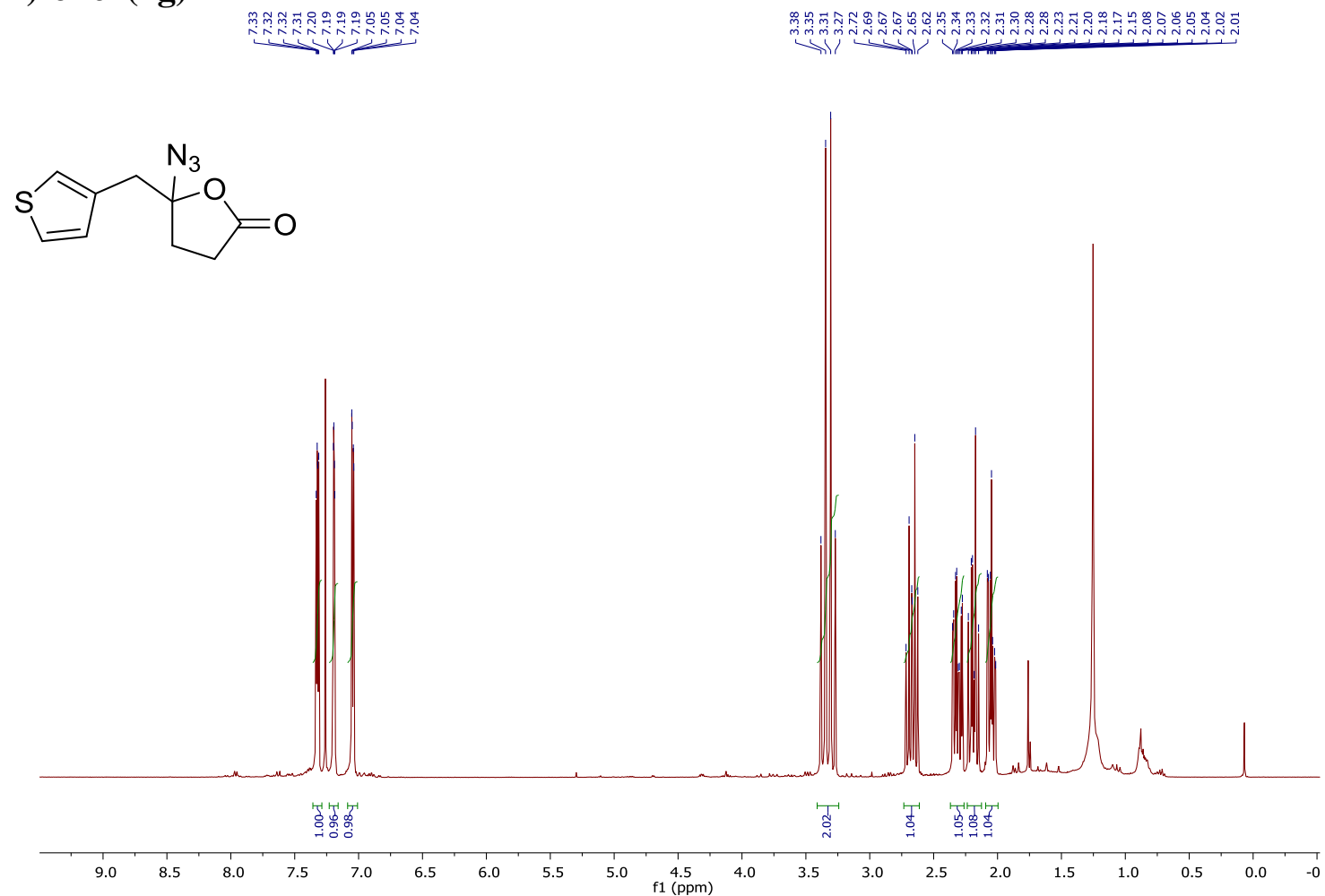

${ }^{13} \mathrm{C}$-NMR $\left(101 \mathrm{MHz}, \mathrm{CDCl}_{3}\right)$ of compound 5-azido-5-(thiophen-3-ylmethyl)dihydrofuran2(3H)-one (4g)
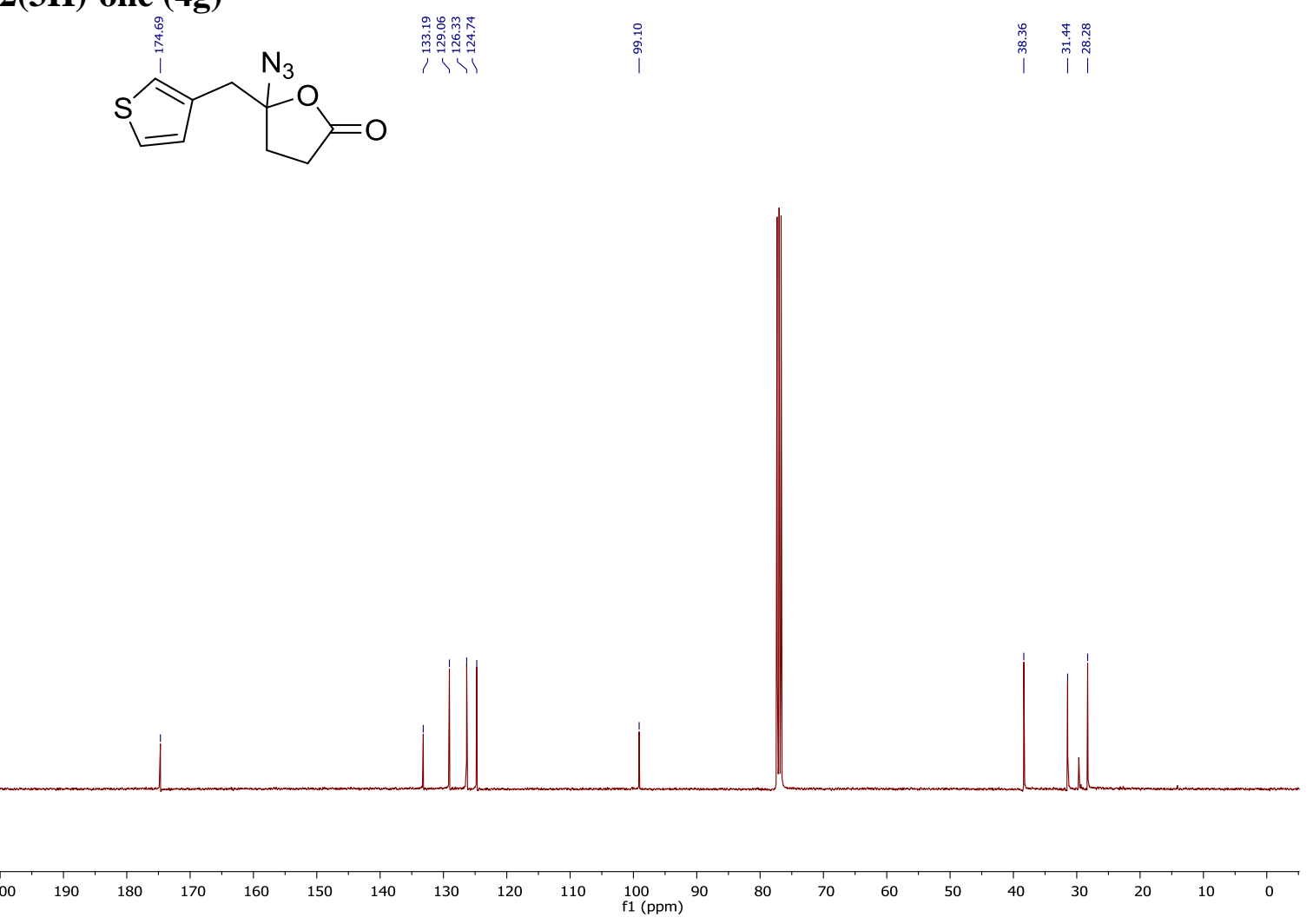
IR of compound 5-azido-5-(thiophen-3-ylmethyl)dihydrofuran-2(3H)-one (4g)

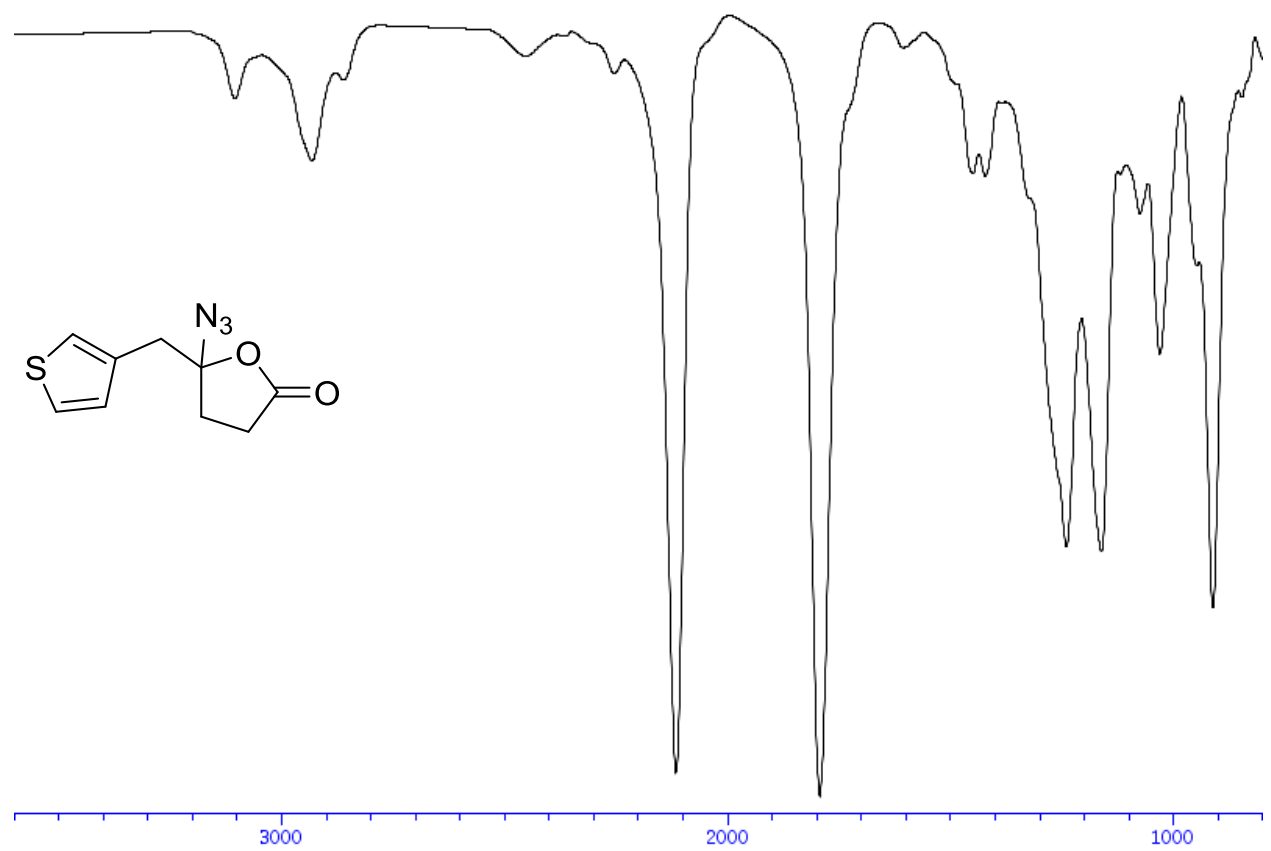

${ }^{\mathbf{1}} \mathbf{H}$ NMR $\left(400 \mathrm{MHz}, \mathrm{CDCl}_{3}\right.$ ) of compound 5-azido-5-benzyl-3,3-dimethyldihydrofuran-2(3H)one (4h)

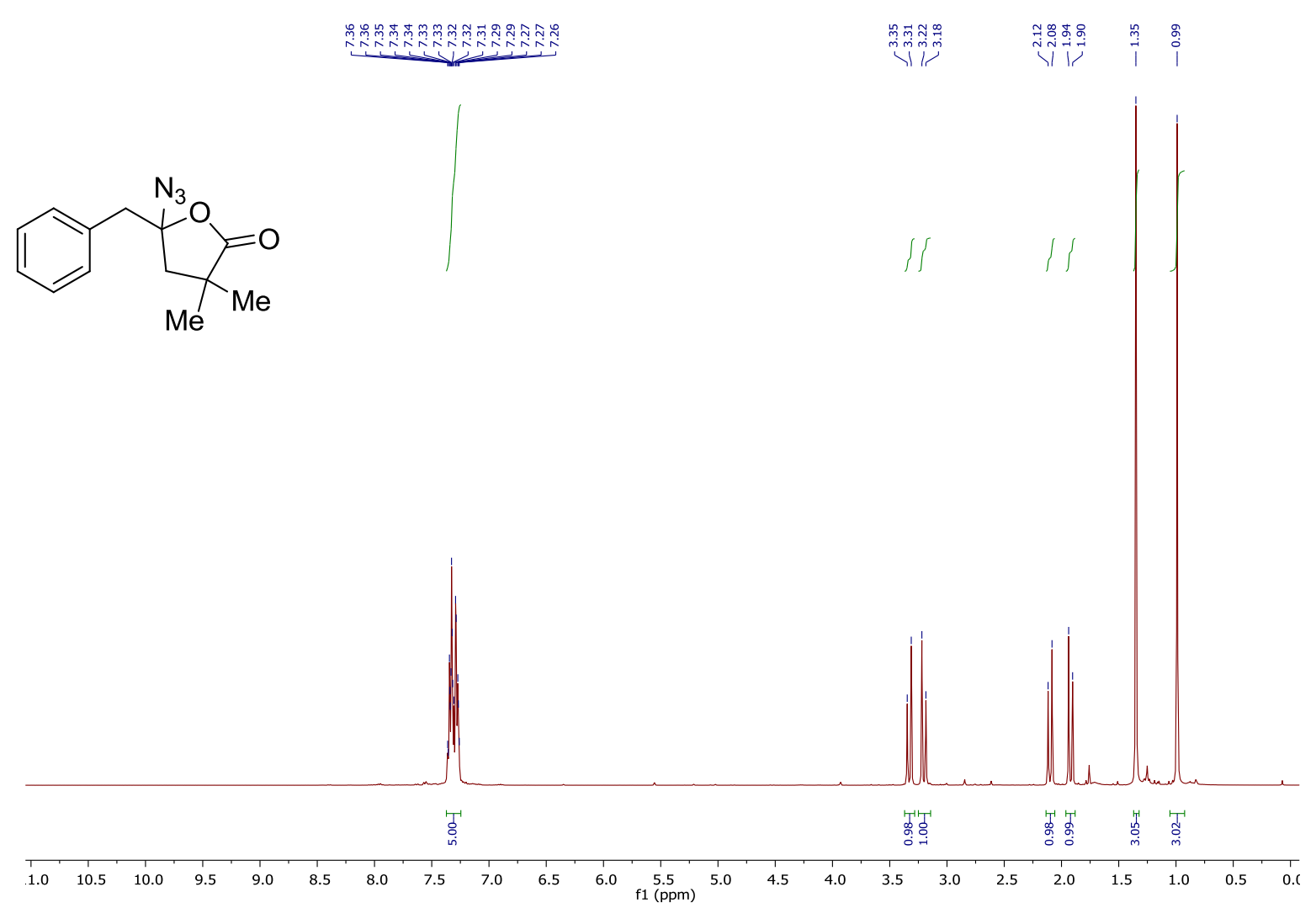


${ }^{13}$ C NMR (101 MHz, $\mathrm{CDCl}_{3}$ ) of compound 5-azido-5-benzyl-3,3-dimethyldihydrofuran2(3H)-one (4h)
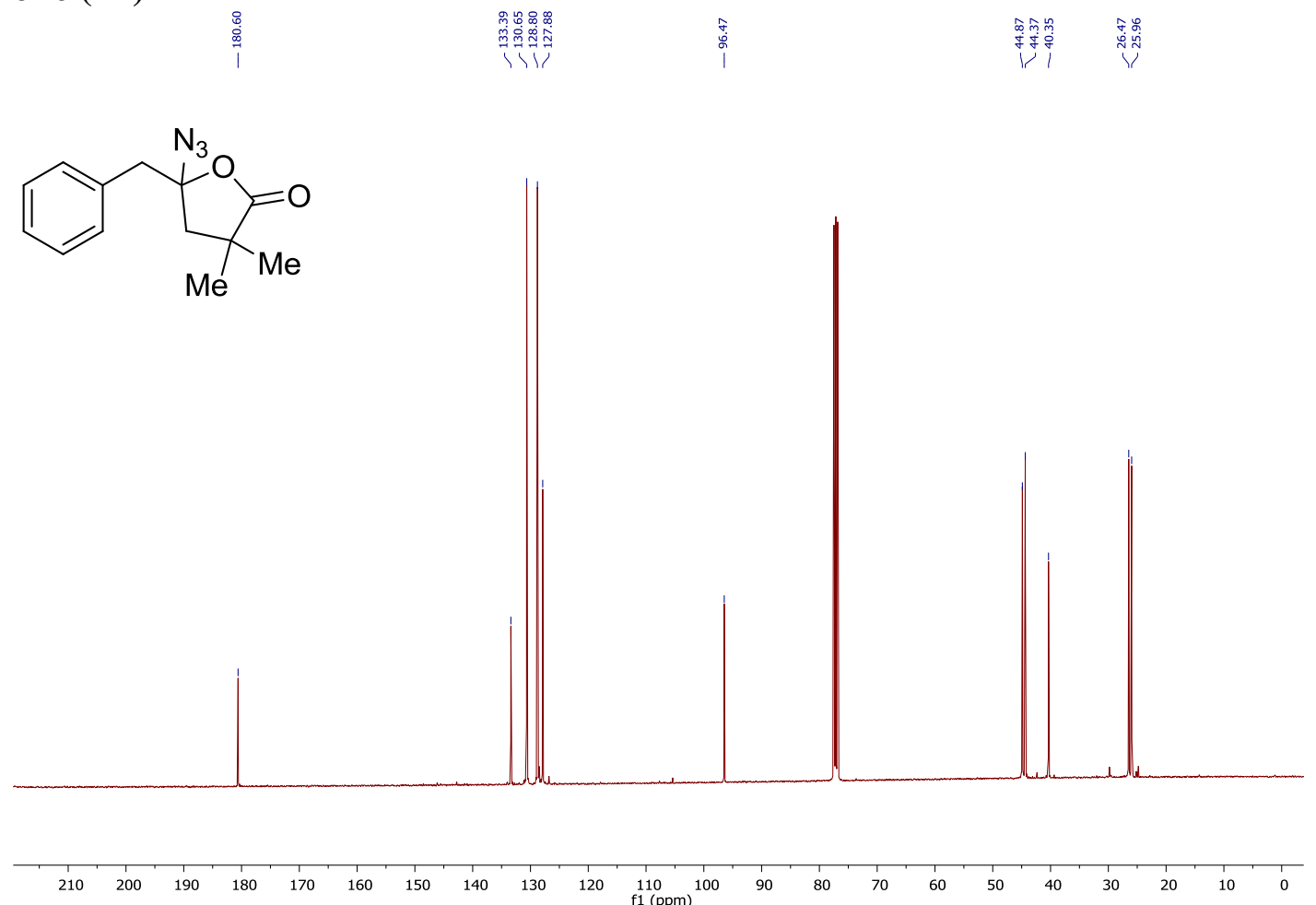

IR of compound 5-azido-5-benzyl-3,3-dimethyldihydrofuran-2(3H)-one (4h)

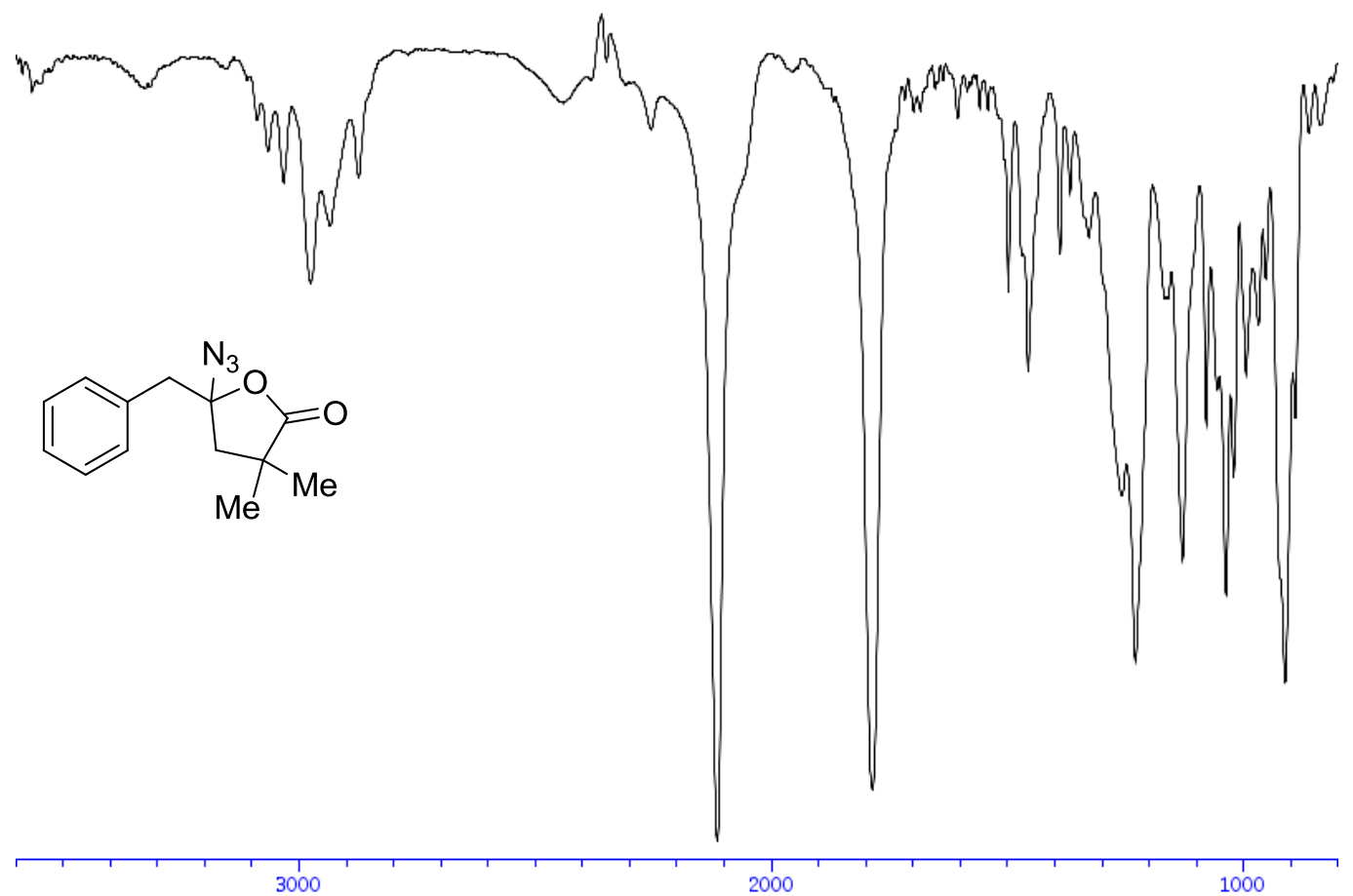


${ }^{\mathbf{1}} \mathbf{H}$-NMR (400 MHz, $\mathrm{CDCl}_{3}$ ) of compound 3-azido-3-benzylisobenzofuran-1(3H)-one (4i)

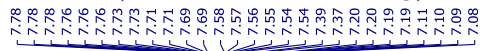
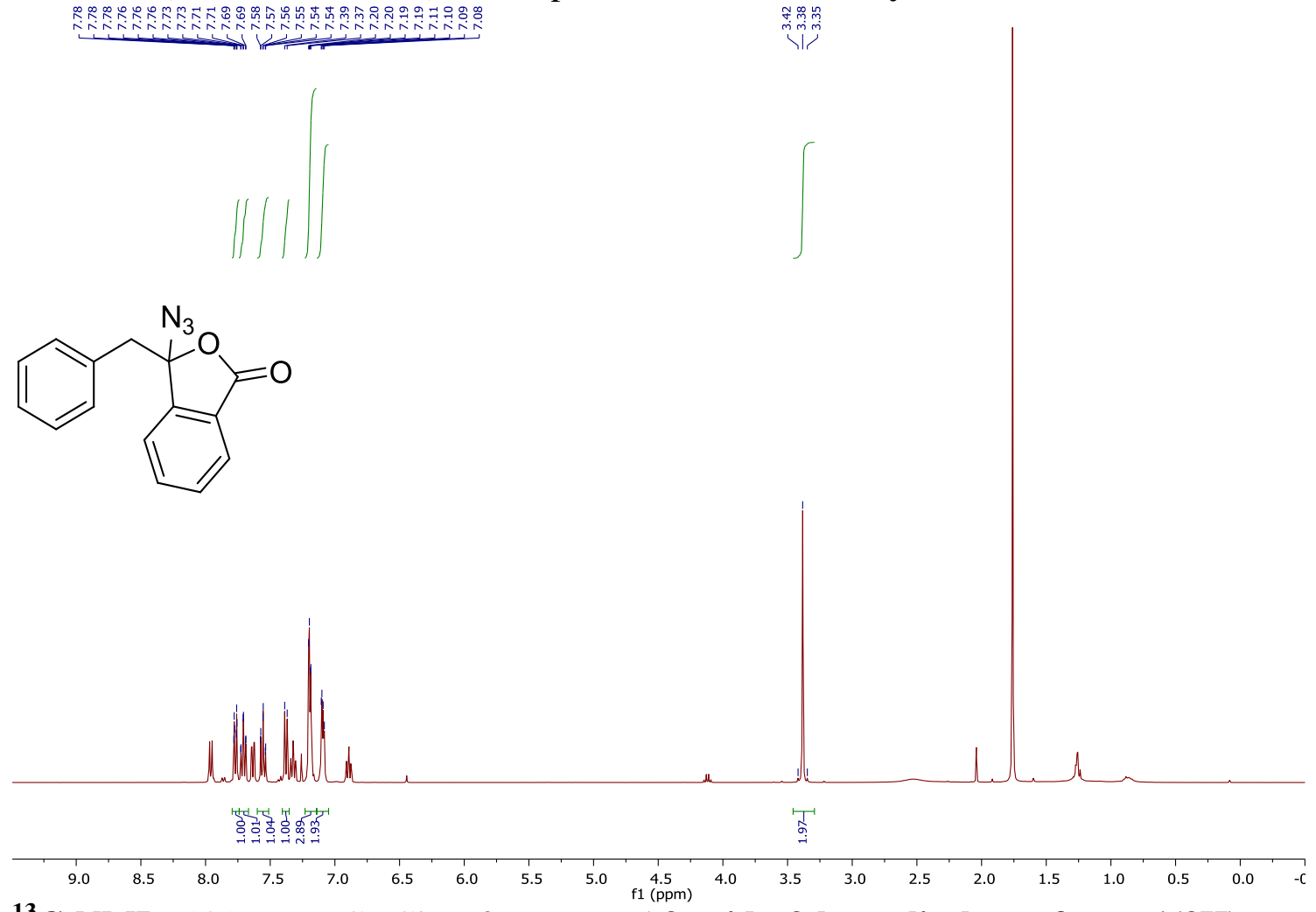

${ }^{13}$ C-NMR (101 MHz, $\mathrm{CDCl}_{3}$ ) of compound 3-azido-3-benzylisobenzofuran-1(3H)-one (4i)

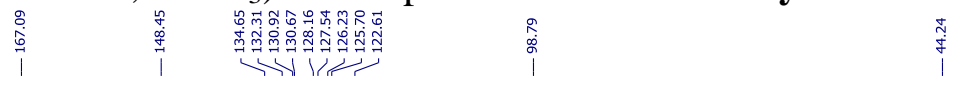<smiles>NC1(Cc2ccccc2)OC(=O)c2ccccc21</smiles>

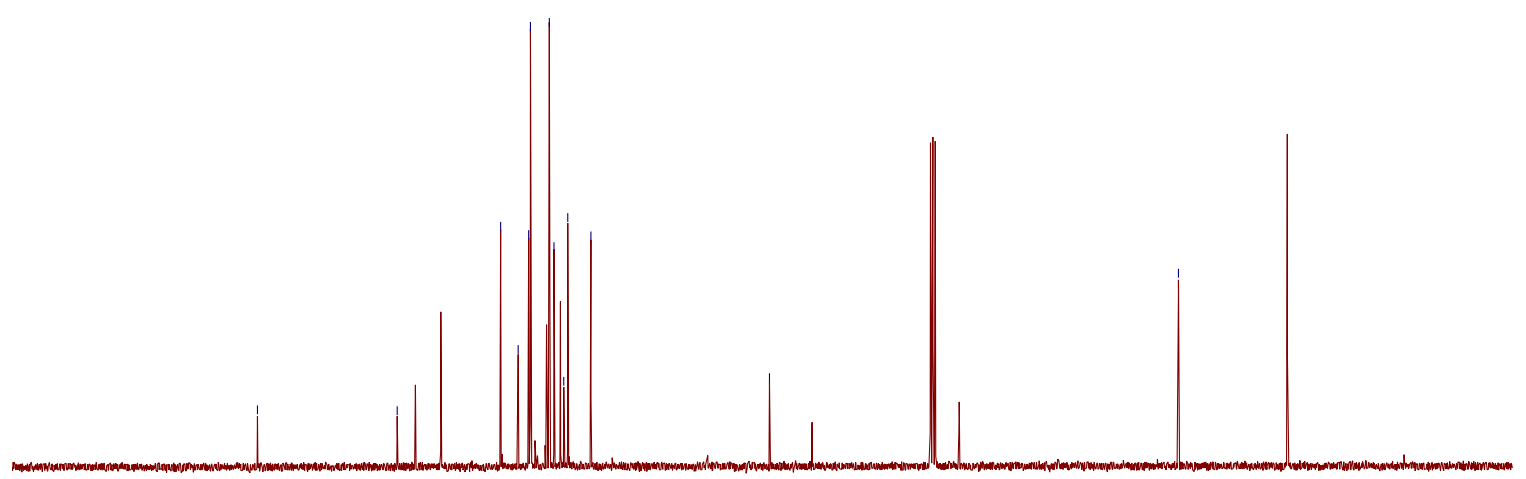

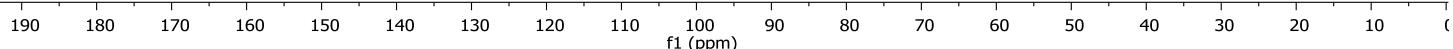


${ }^{1} \mathbf{H}-\mathrm{NMR}\left(400 \mathrm{MHz}, \mathrm{CDCl}_{3}\right.$ ) of compound 3-azido-3-(4-chlorobenzyl)isobenzofuran-1(3H)one $(\mathbf{4 j})$

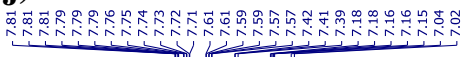

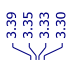<smiles>C=CC(C)C</smiles>
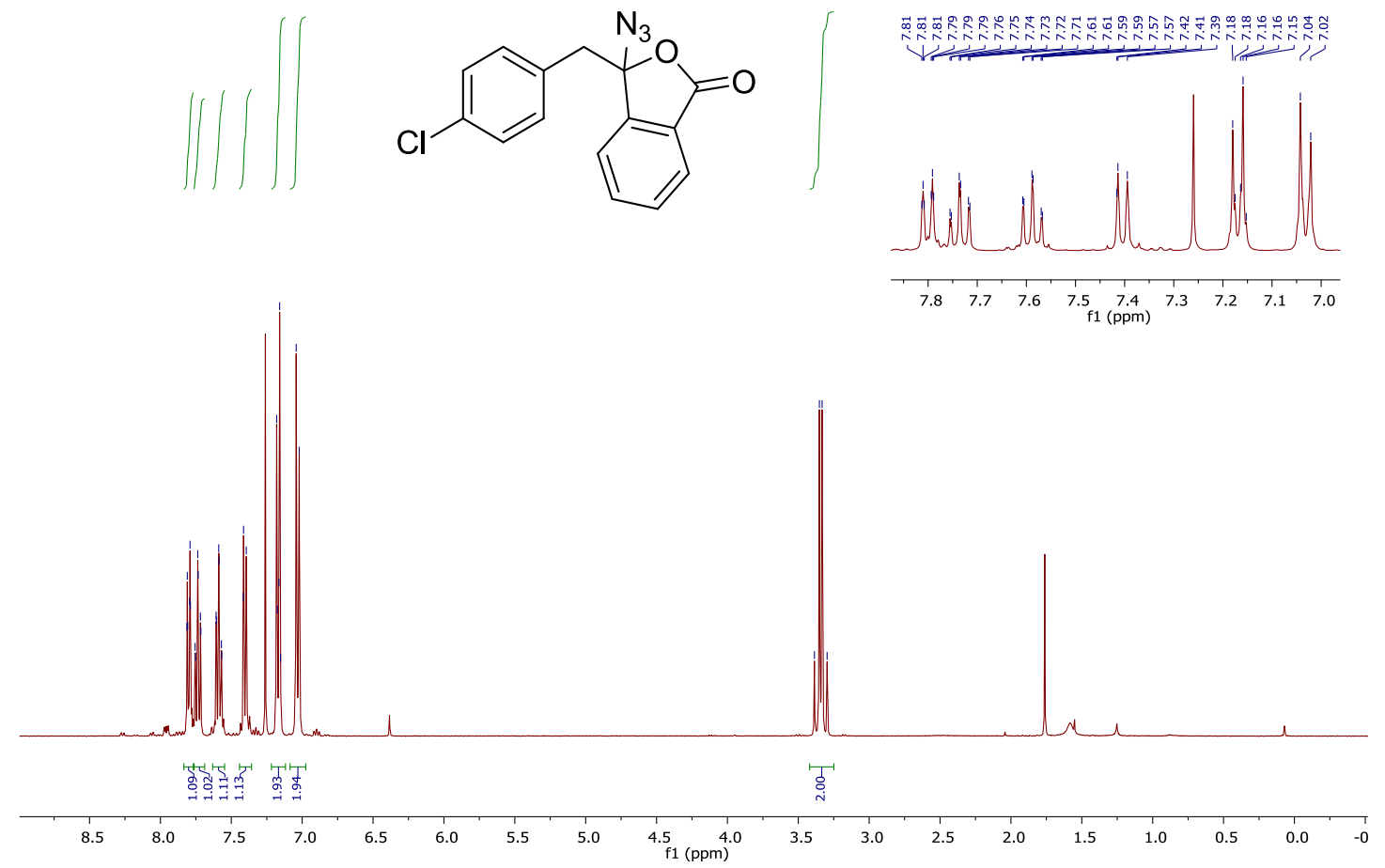

${ }^{13} \mathbf{C}$-NMR (101 MHz, $\mathrm{CDCl}_{3}$ ) of compound 3-azido-3-(4-chlorobenzyl)isobenzofuran-1(3H)one $(\mathbf{4 j})$

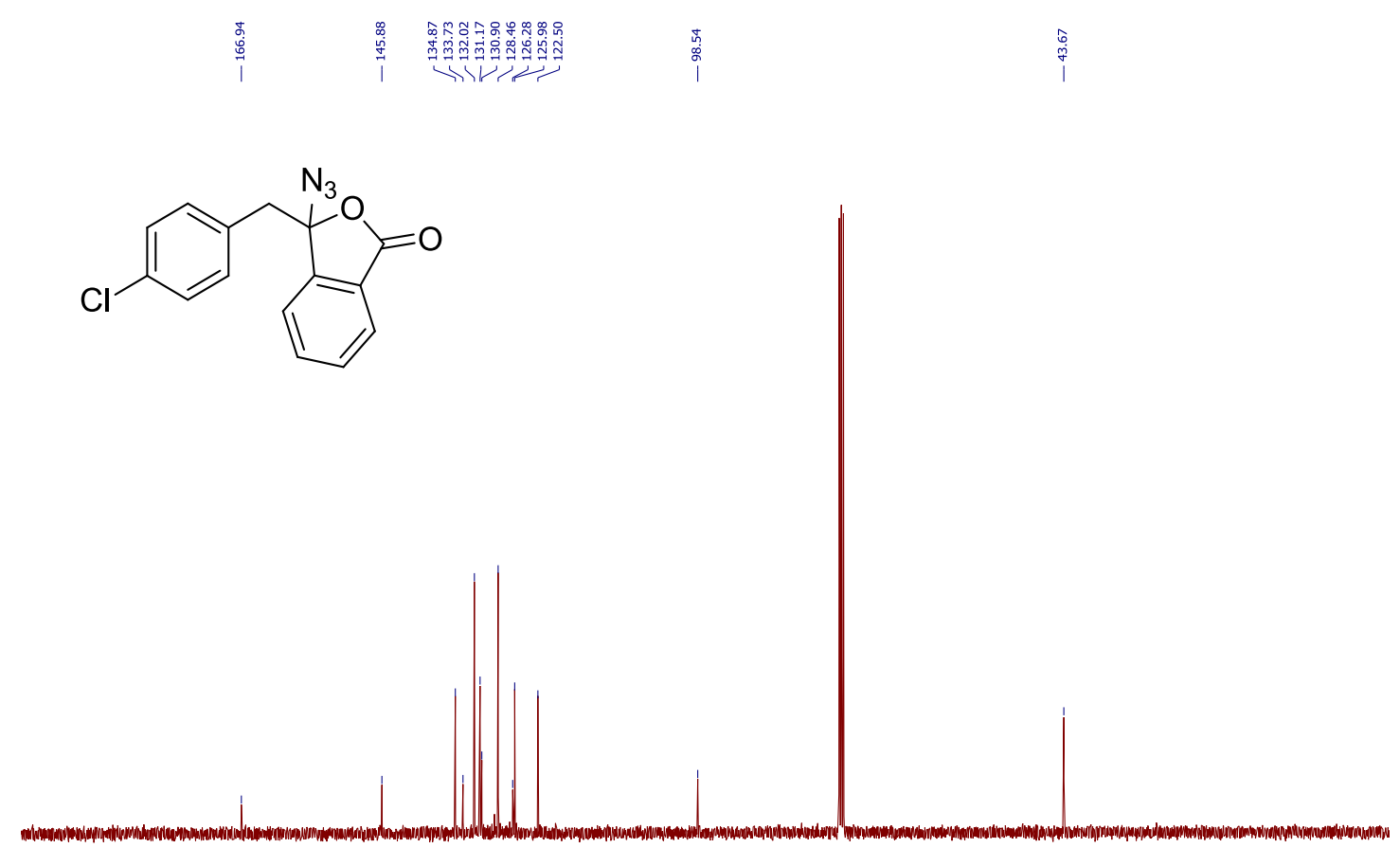


IR of compound 3-azido-3-(4-chlorobenzyl)isobenzofuran-1(3H)-one (4j)

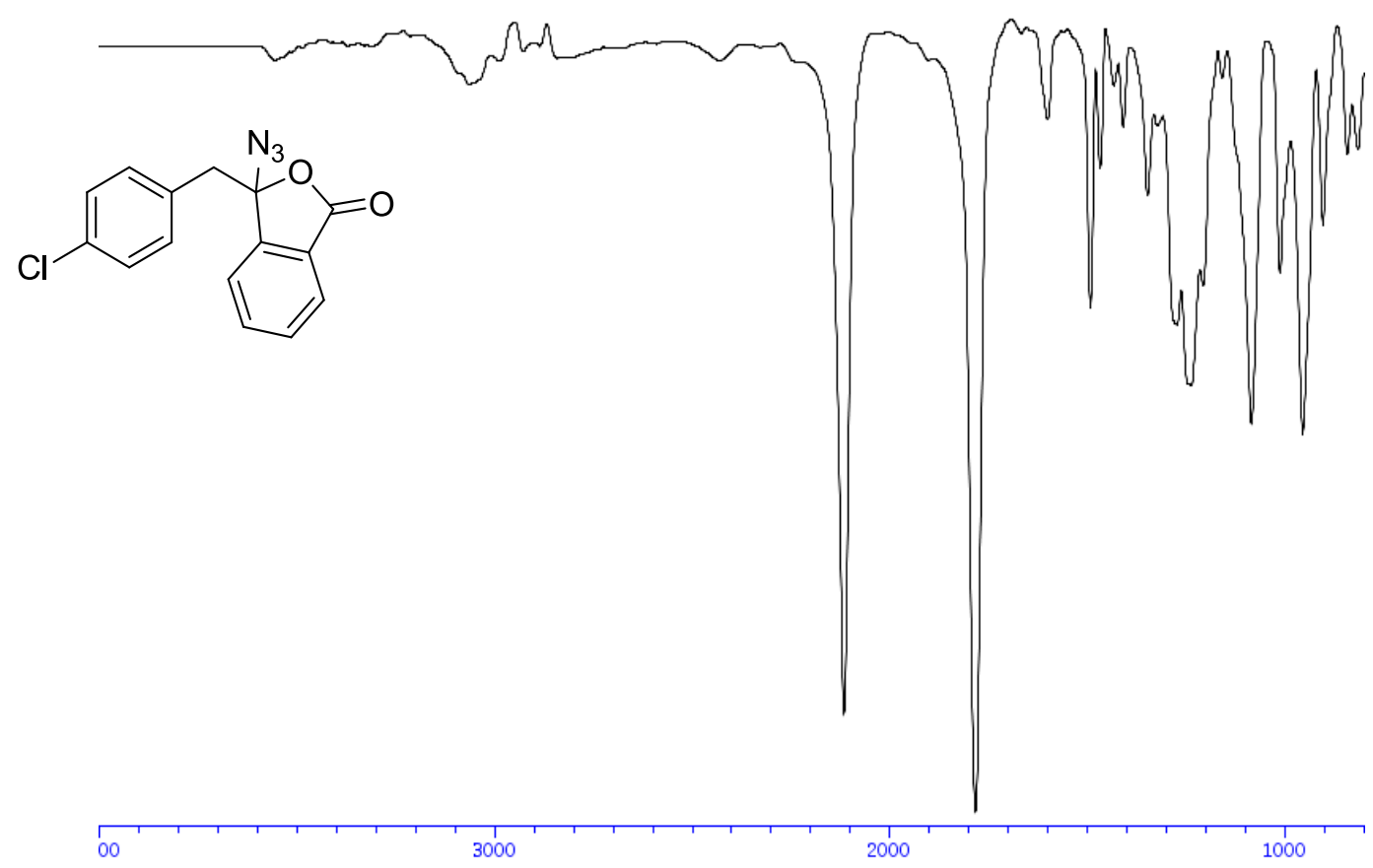

${ }^{1} \mathbf{H}-\mathrm{NMR}\left(400 \mathrm{MHz}, \mathrm{CDCl}_{3}\right.$ ) of compound 3-azido-3-(4-fluorobenzyl)isobenzofuran-1(3H)-

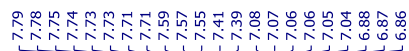
one

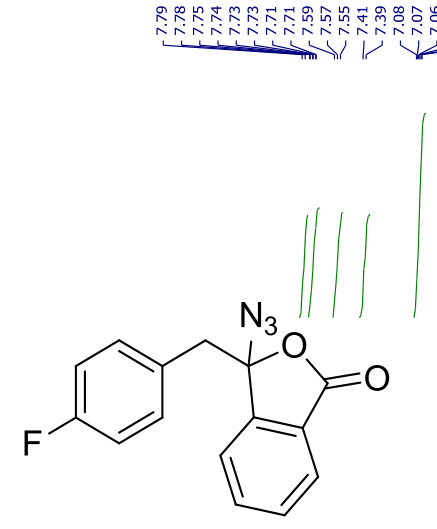

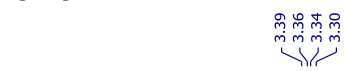

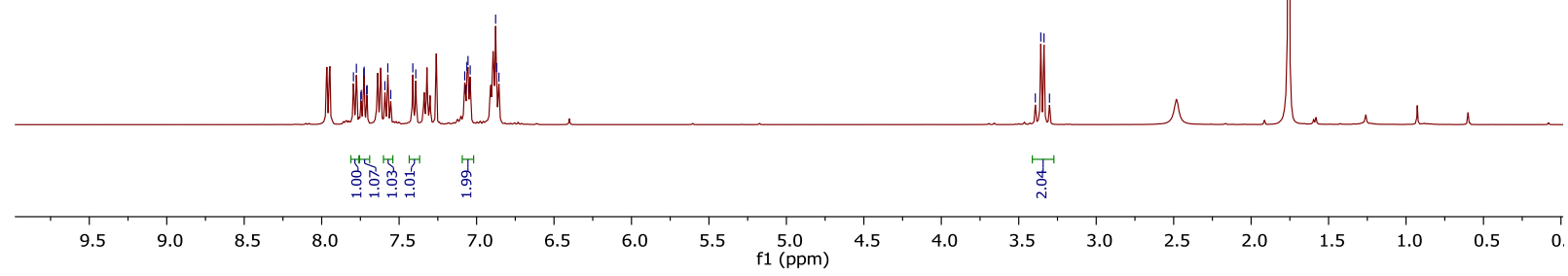


${ }^{13} \mathbf{C}-\mathbf{N M R}\left(101 \mathrm{MHz}, \mathrm{CDCl}_{3}\right)$ of compound 3-azido-3-(4-fluorobenzyl)isobenzofuran-1(3H)one
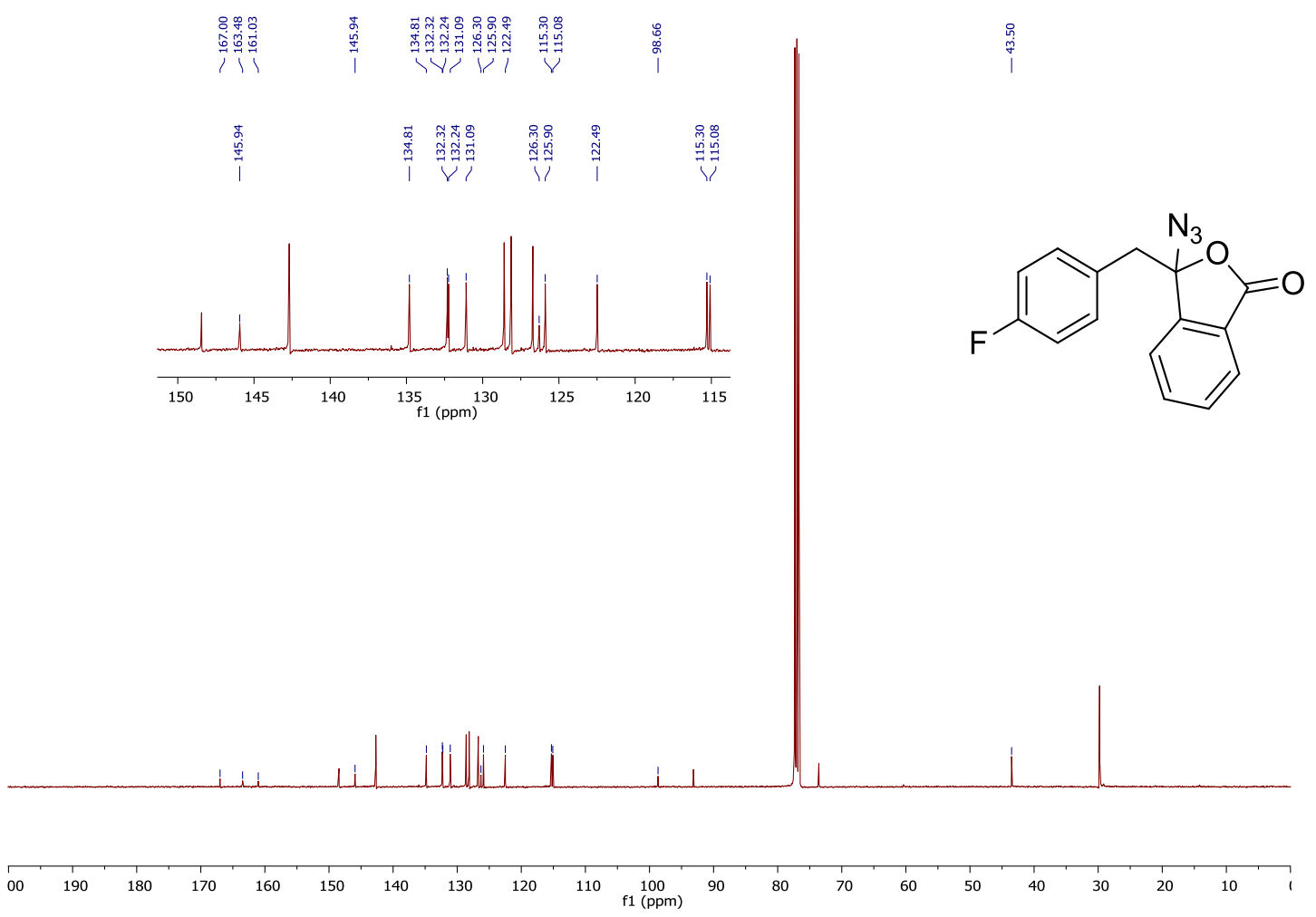

${ }^{19}$ F NMR (376 MHz, $\mathrm{CDCl}_{3}$ ) of compound 3-azido-3-(4-fluorobenzyl)isobenzofuran-1(3H)one<smiles>NC1(Cc2ccc(F)cc2)OC(=O)c2ccccc21</smiles>
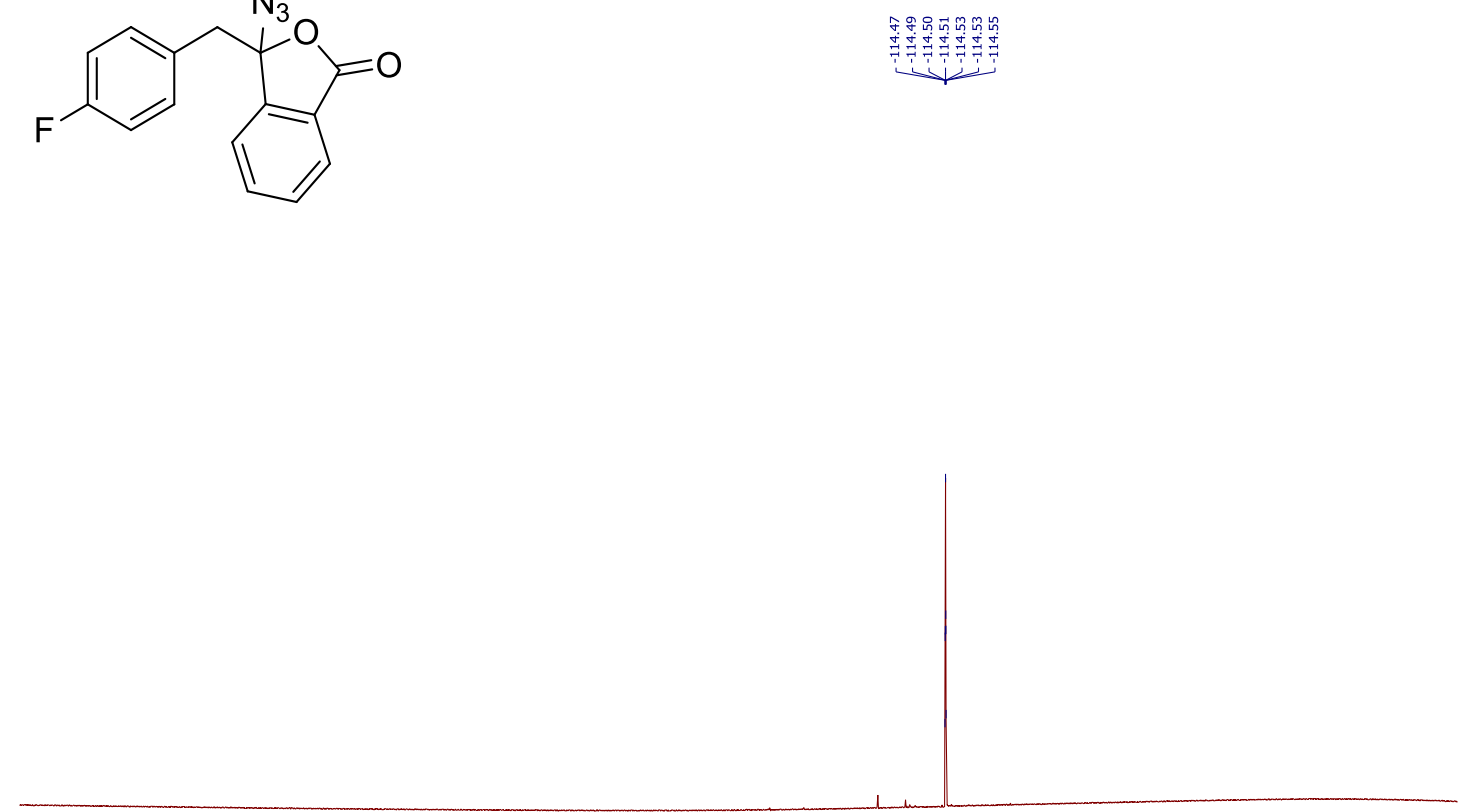


\section{d. spectra of new compounds from the Pd catalysis.}

${ }^{\mathbf{1}} \mathbf{H}-\mathrm{NMR}$ (400 MHz, $\mathrm{CDCl}_{3}$ ) of compound 5-(azidomethyl)-5-(3-phenylpropyl)dihydrofuran2(3H)-one (2s)

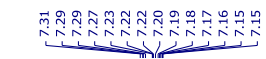

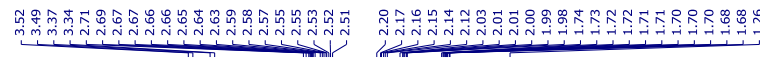
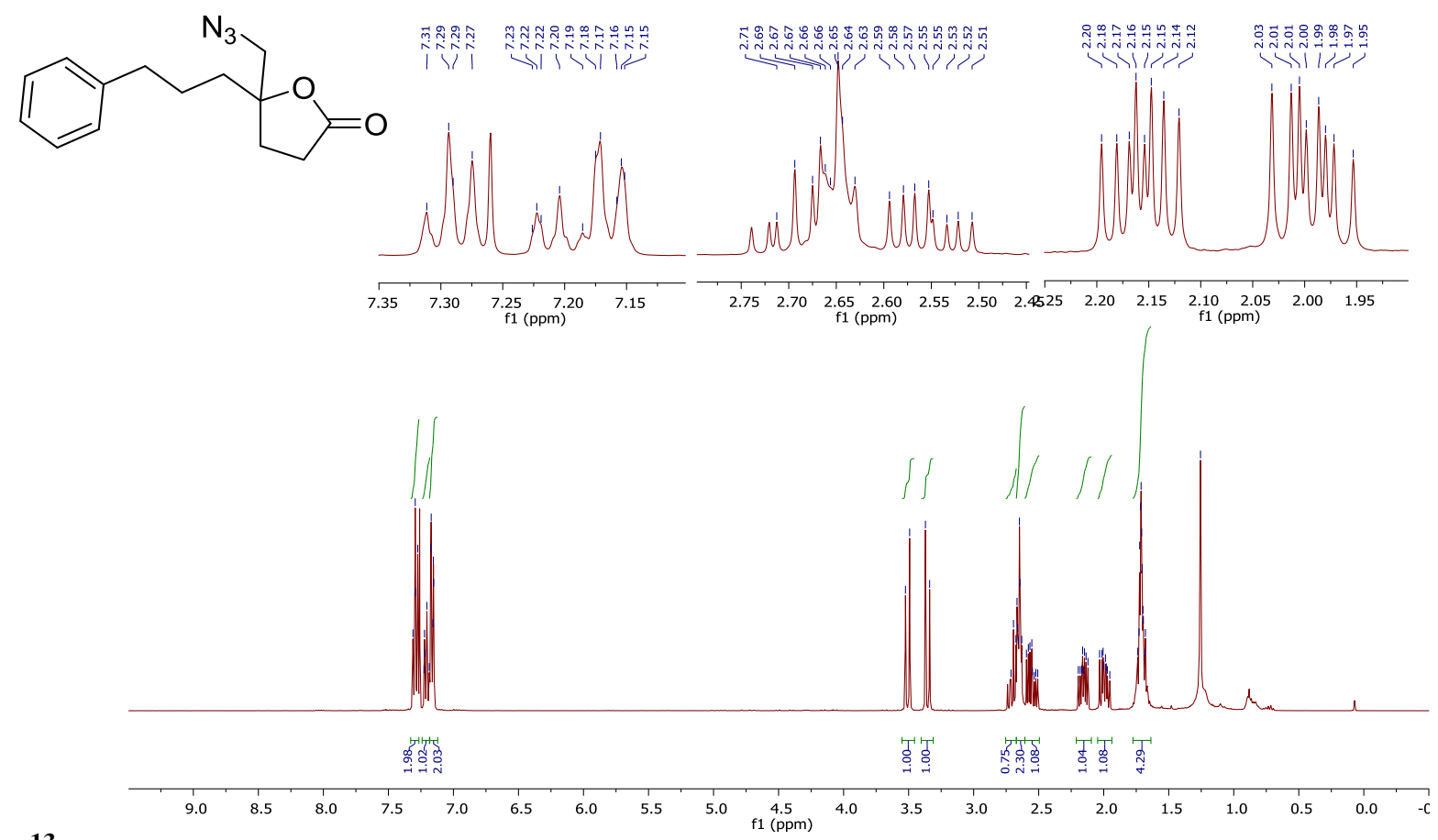

${ }^{13} \mathrm{C}-\mathrm{NMR}\left(101 \mathrm{MHz}, \mathrm{CDCl}_{3}\right)$ of compound 5-(azidomethyl)-5-(3-phenylpropyl)dihydrofuran2(3H)-one (2s)
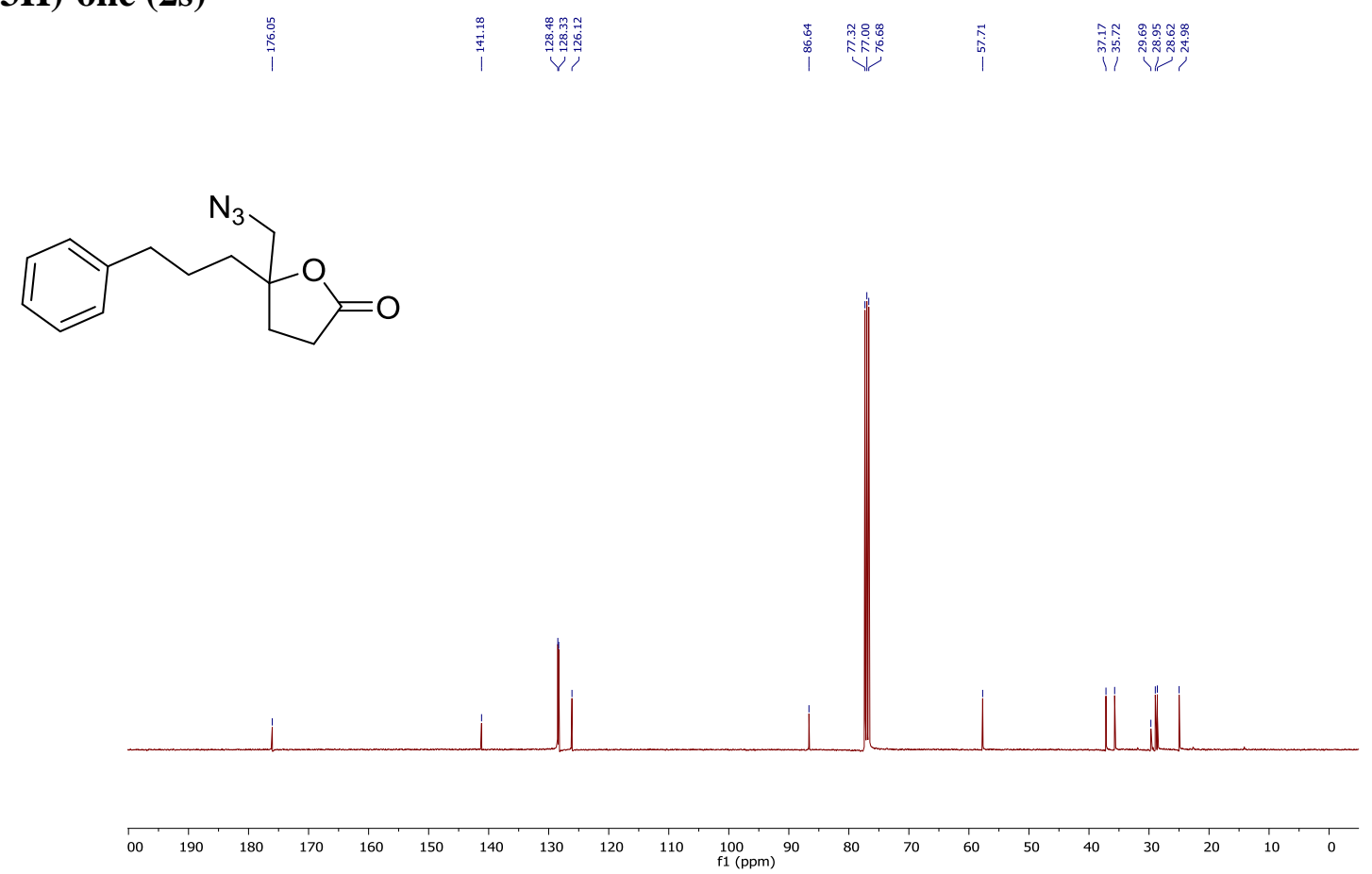
IR of compound 5-(azidomethyl)-5-(3-phenylpropyl)dihydrofuran-2(3H)-one (s)

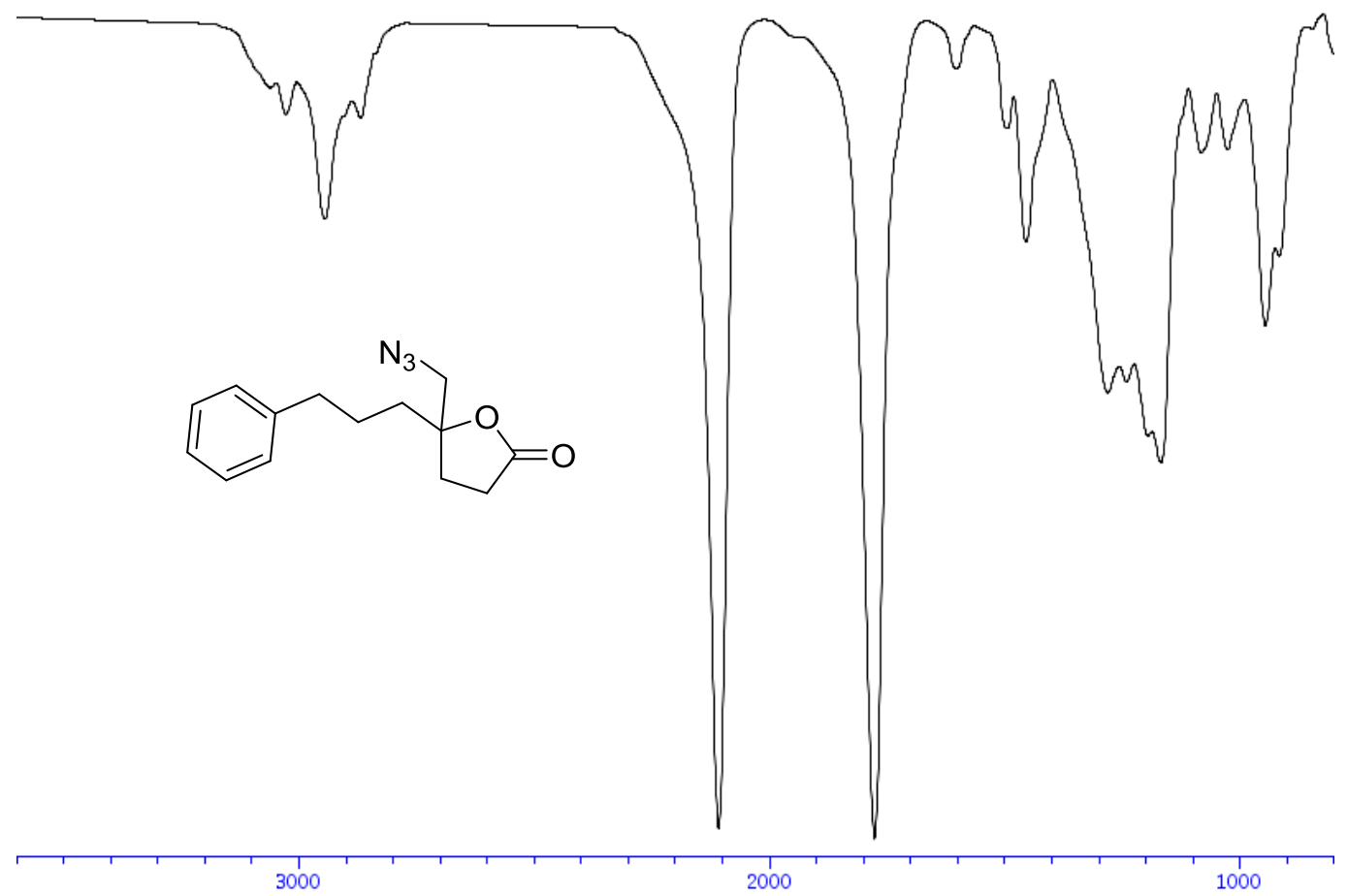

${ }^{\mathbf{1}} \mathbf{H}$ NMR (400 MHz, $\mathrm{CDCl}_{3}$ ) of compound 3-(azidomethyl)-3-methylisobenzofuran-1(3H)-one (2g)

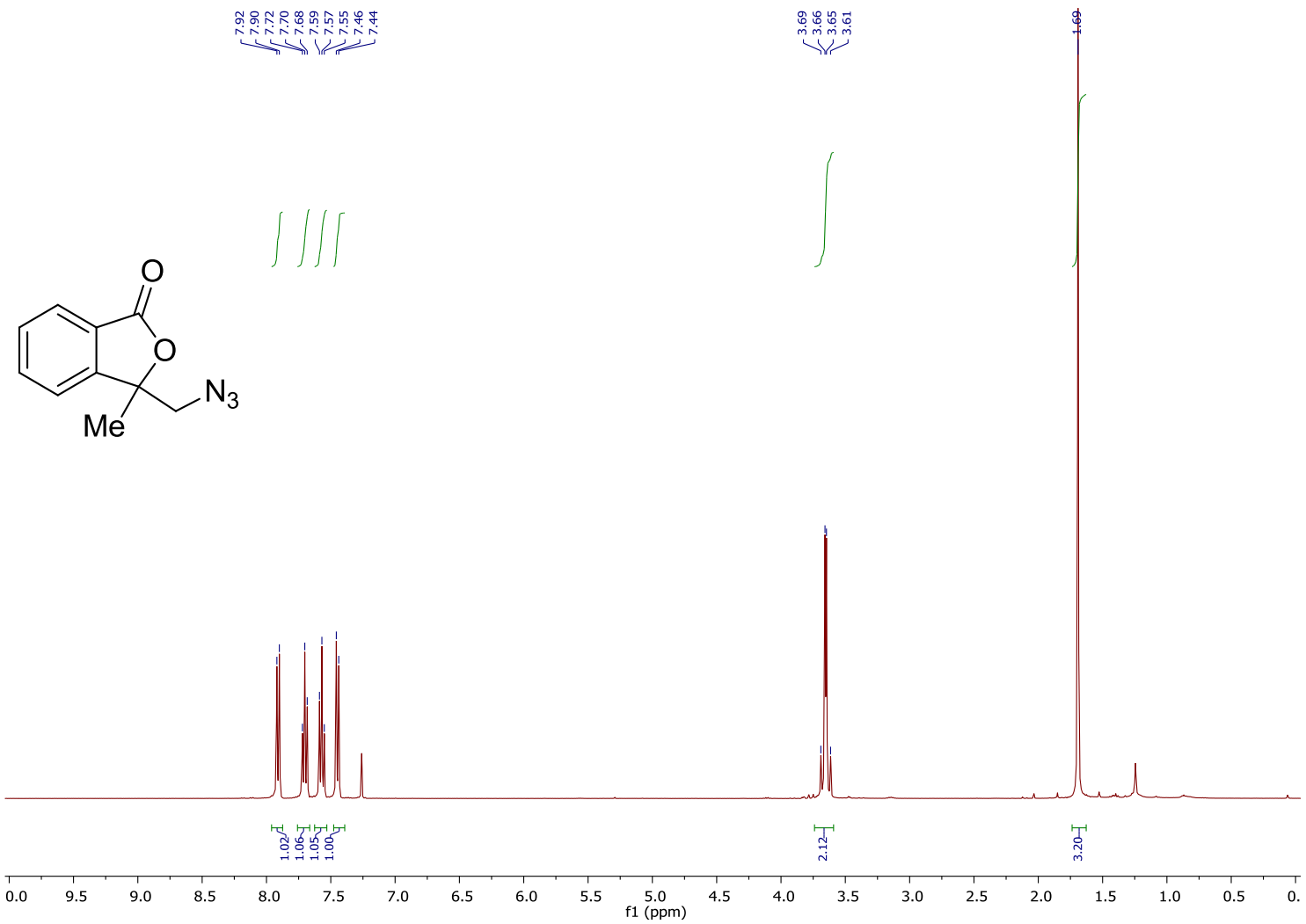


${ }^{13} \mathbf{C}$ NMR (101 MHz, $\left.\mathrm{CDCl}_{3}\right)$ of compound 3-(azidomethyl)-3-methylisobenzofuran-1(3H)one (2g)

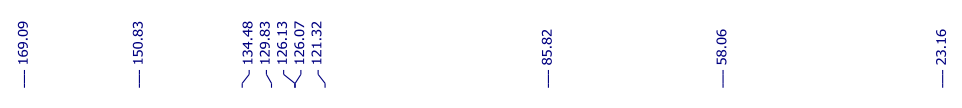<smiles>CC1(CN)OC(=O)c2ccccc21</smiles>
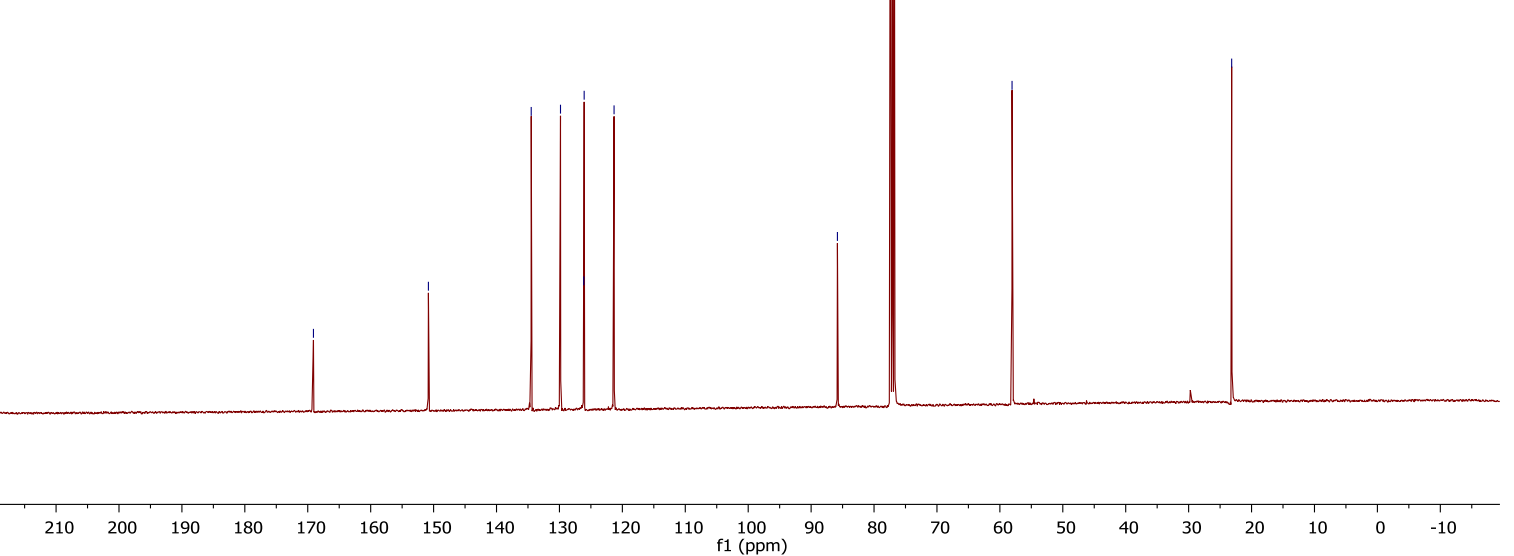

IR of compound 3-(azidomethyl)-3-methylisobenzofuran-1(3H)-one (2g)

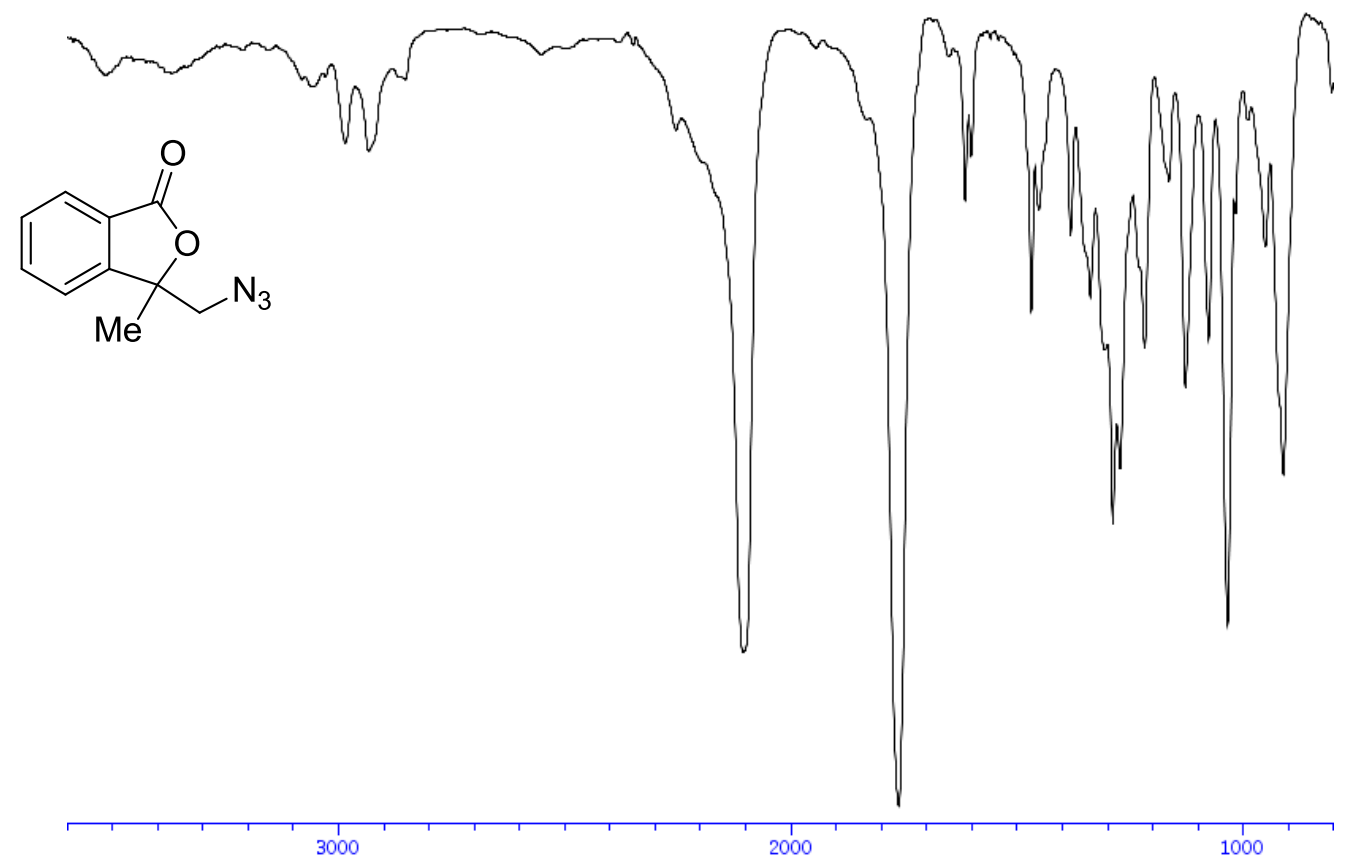


${ }^{\mathbf{1}} \mathbf{H}$-NMR (400 MHz, CDCl3) of compound 3-(azidomethyl)isochroman-1-one (2t)

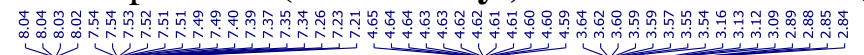<smiles>NCC1Cc2ccccc2C(=O)O1</smiles>
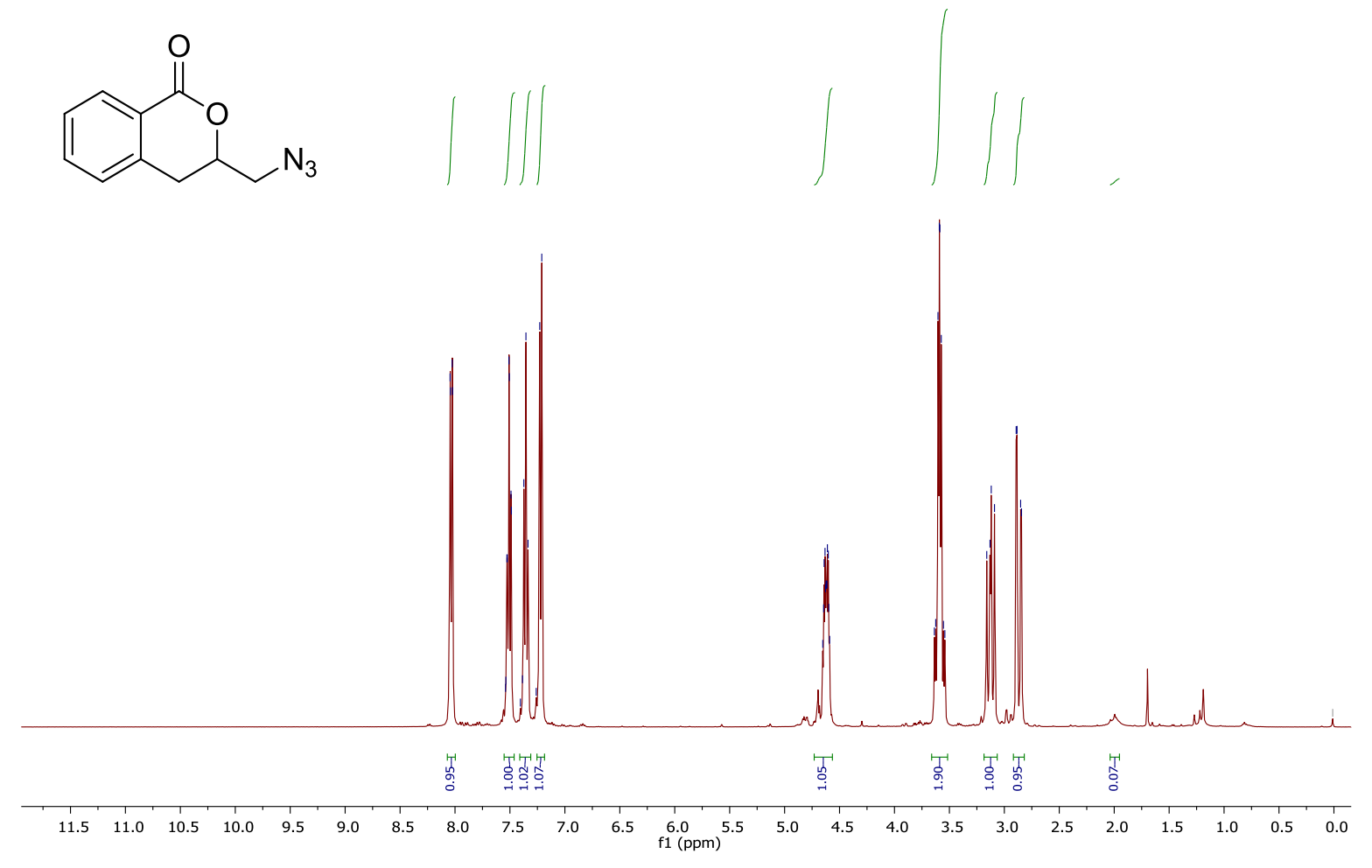

${ }^{13}$ C-NMR (101 MHz, $\mathrm{CDCl}_{3}$ ) of compound 3-(azidomethyl)isochroman-1-one (2t)

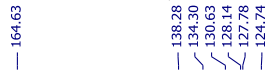<smiles>NCC1Cc2ccccc2C(=O)O1</smiles>

$\begin{array}{lllllllllll}210 & 200 & 190 & 180 & 170 & 160 & 150 & 140 & 130 & 120 & 110 \begin{array}{c}100 \\ \mathrm{f} 1(\mathrm{ppm})\end{array}\end{array}$ 
IR of compound 3-(azidomethyl)isochroman-1-one (2t)

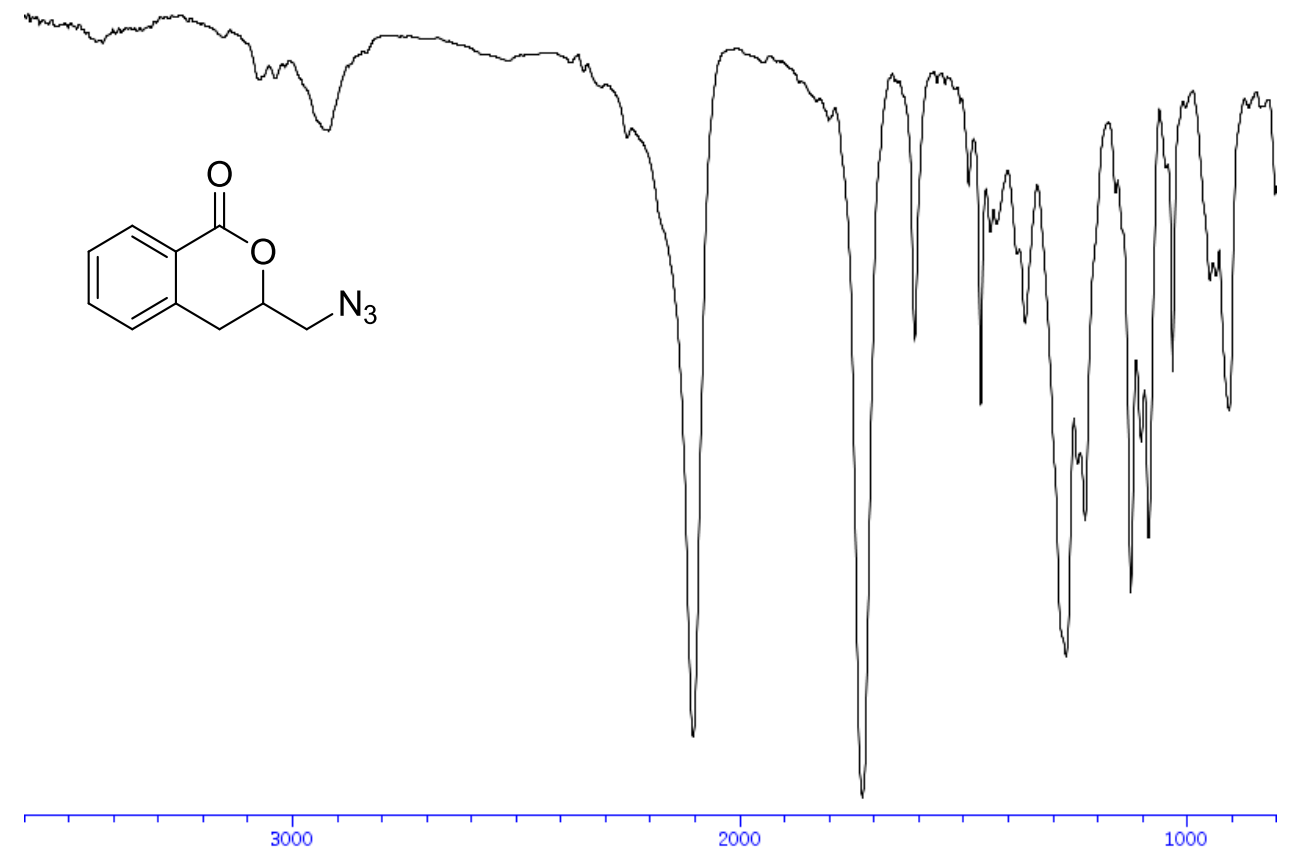

${ }^{1} \mathbf{H}-\mathrm{NMR}$ (400 MHz, CDCl3) of compound 3-(Azidomethyl)-3-methylisochroman-1-one (2u)

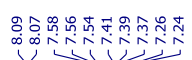<smiles>CC1(CN)Cc2ccccc2C(=O)O1</smiles>

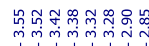

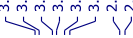
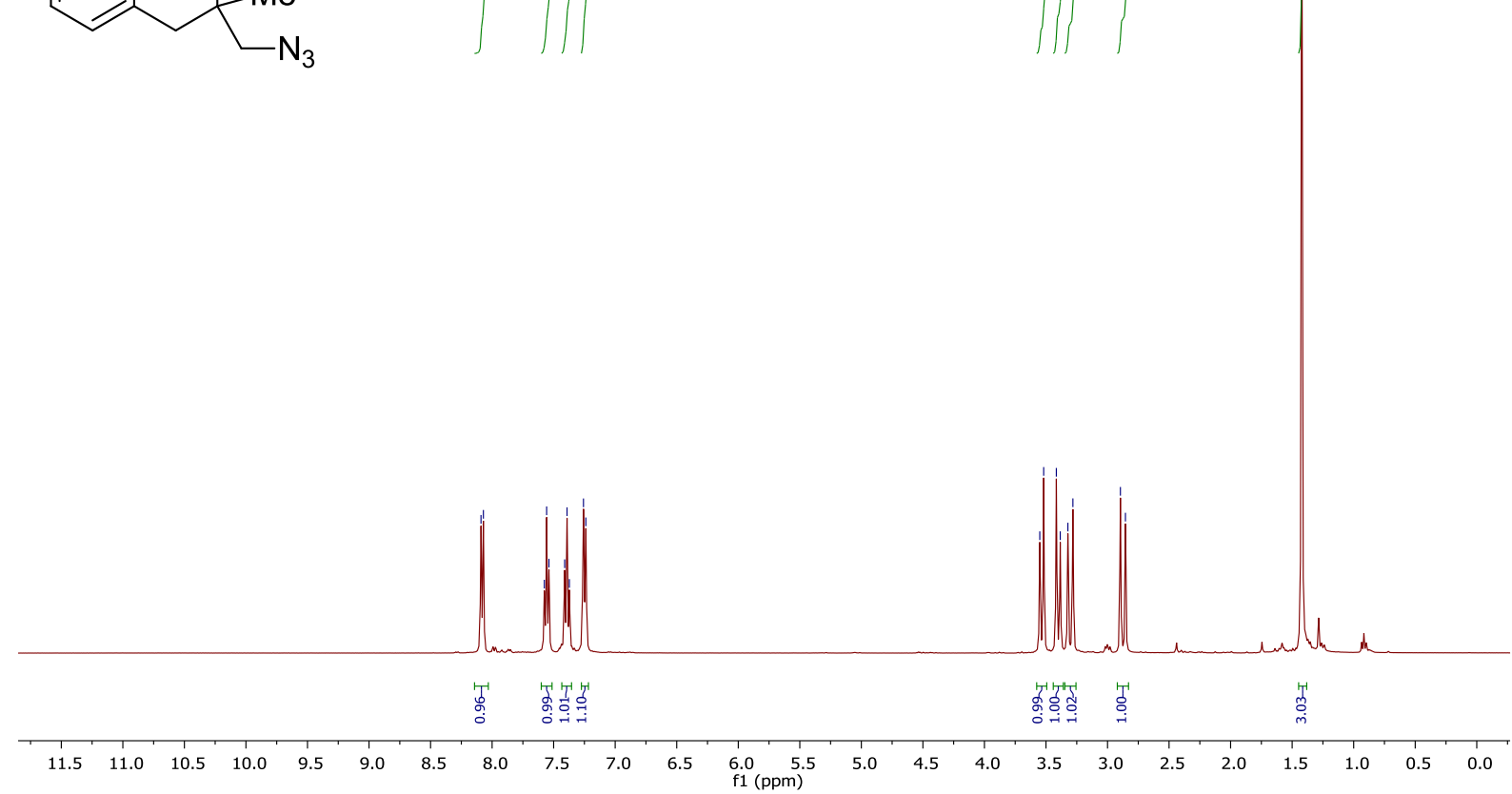
${ }^{\mathbf{1 3}} \mathrm{C}$-NMR (101 MHz, $\mathrm{CDCl}_{3}$ ) of compound 3-(Azidomethyl)-3-methylisochroman-1-one (2u)

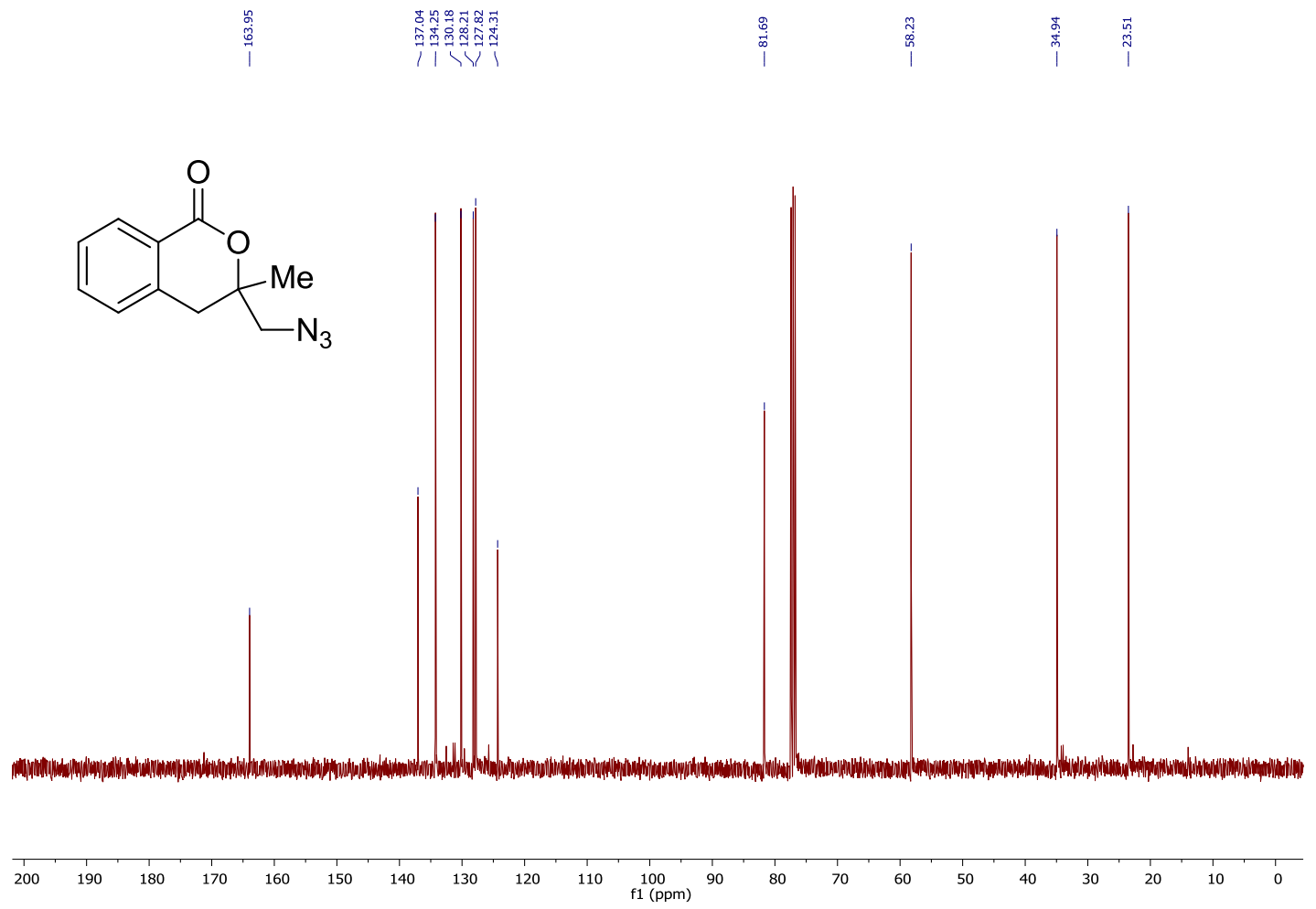

IR of compound 3-(Azidomethyl)-3-methylisochroman-1-one (2u)

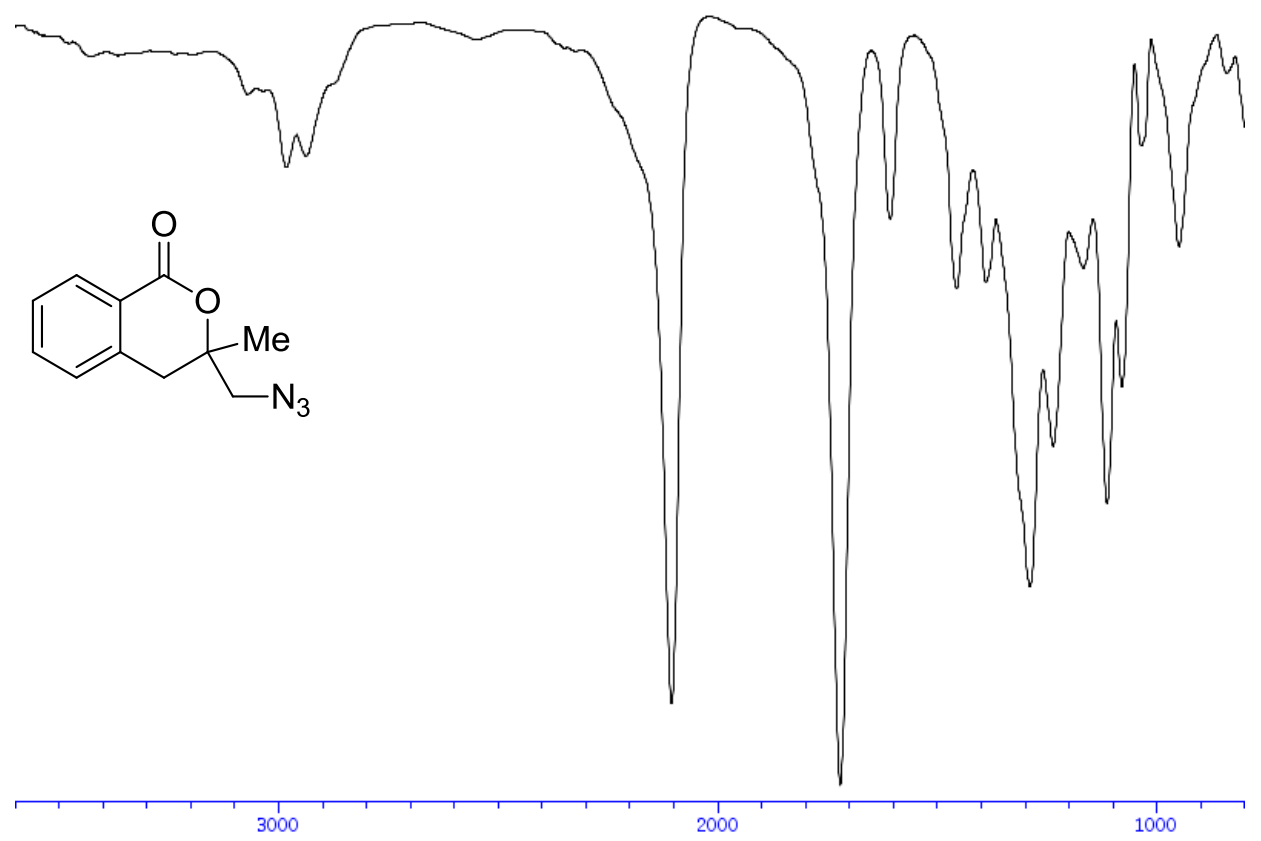


${ }^{\mathbf{1}} \mathbf{H}$-NMR (400 MHz, $\mathrm{CDCl}_{3}$ ) of compound 3-(Azidomethyl)-3((benzyloxy)methyl)isochroman-1-one (2v)<smiles>N#CC1(COCc2ccccc2)Cc2ccccc2C(=O)O1</smiles>
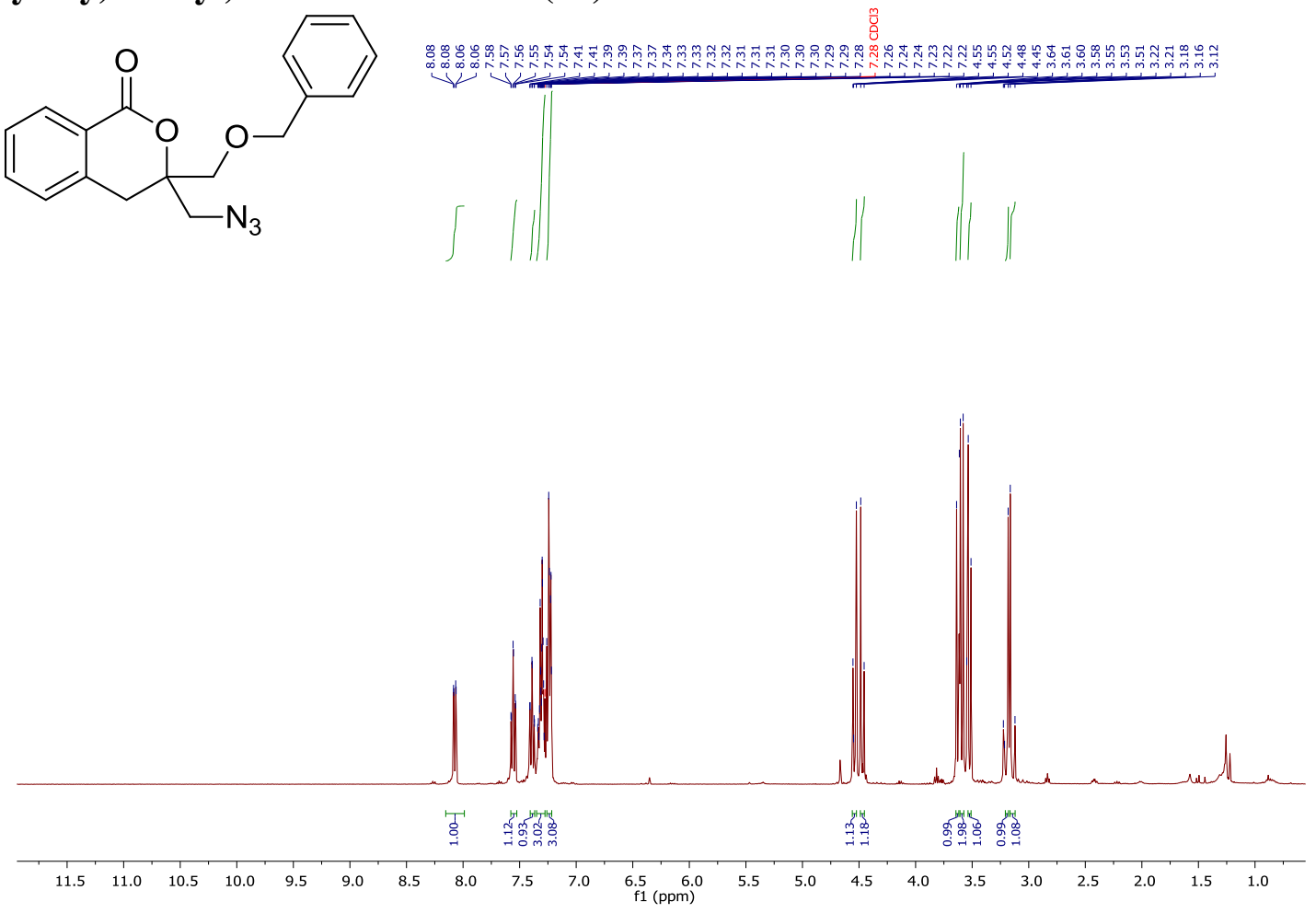

${ }^{13} \mathbf{C}-\mathbf{N M R}\left(101 \mathrm{MHz}, \mathrm{CDCl}_{3}\right)$ of compound 3-(Azidomethyl)-3((benzyloxy)methyl)isochroman-1-one (2v)

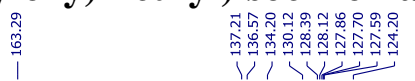<smiles>NCC1(COCc2ccccc2)Cc2ccccc2C(=O)O1</smiles>

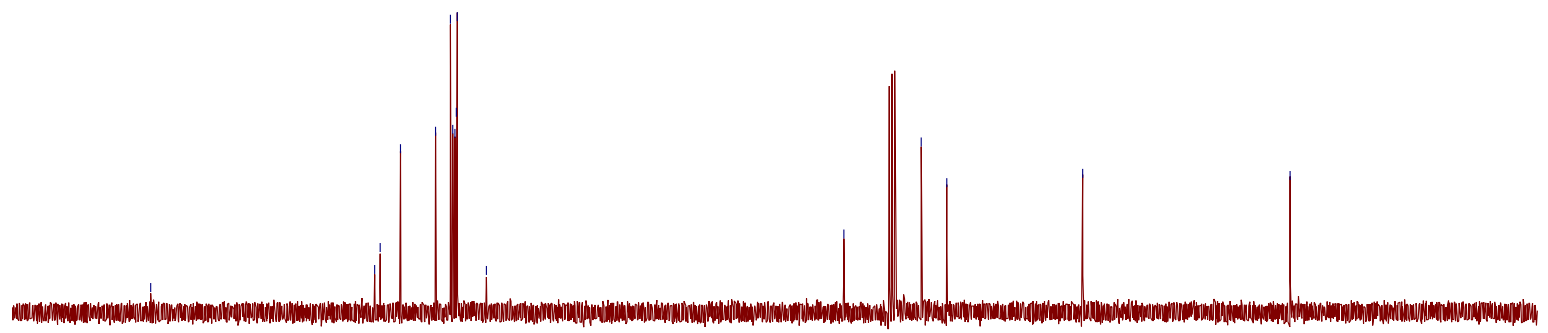

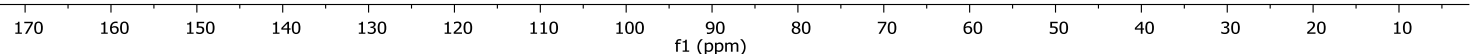


IR of compound 3-(Azidomethyl)-3-((benzyloxy)methyl)isochroman-1-one (XX)

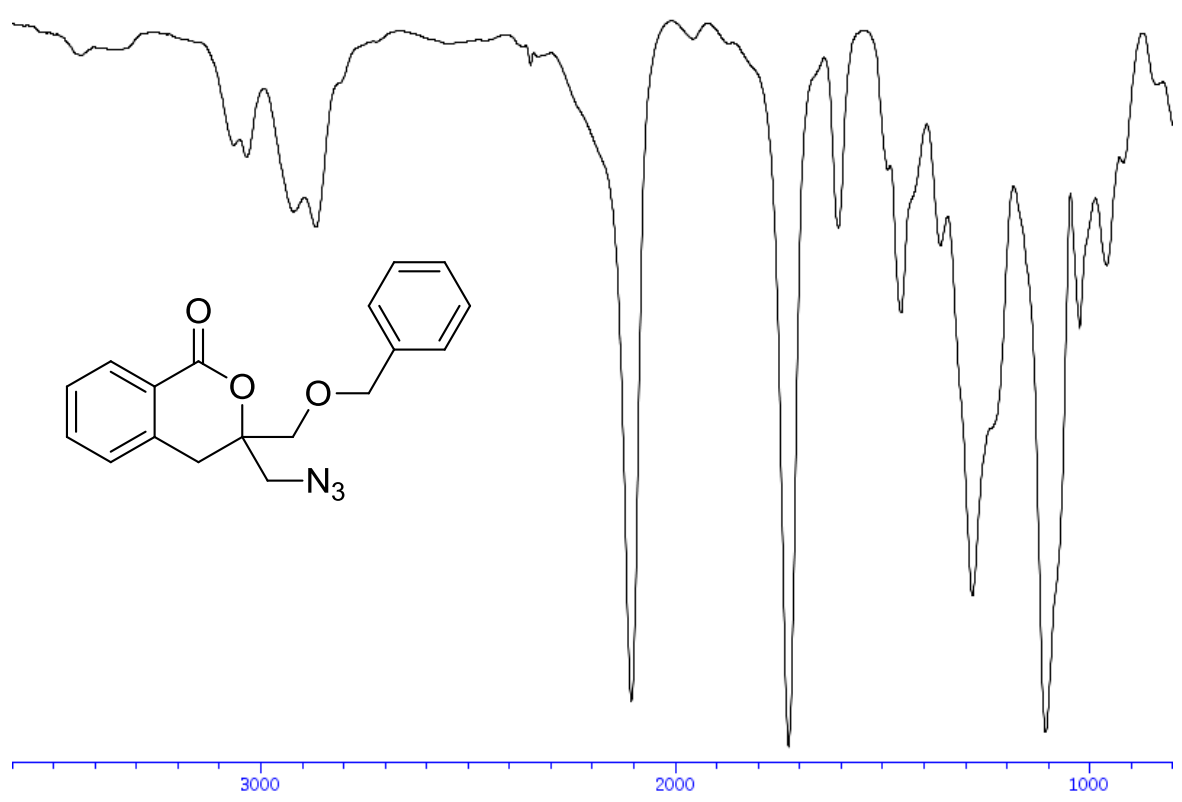




\section{e. Spectra of new compounds from derivatization.}

${ }^{\mathbf{1}} \mathbf{H}-\mathrm{NMR}\left(400 \mathrm{MHz}, \mathrm{CDCl}_{3}\right.$ ) of compound 4-oxo-5-phenylpentanoic acid (6)

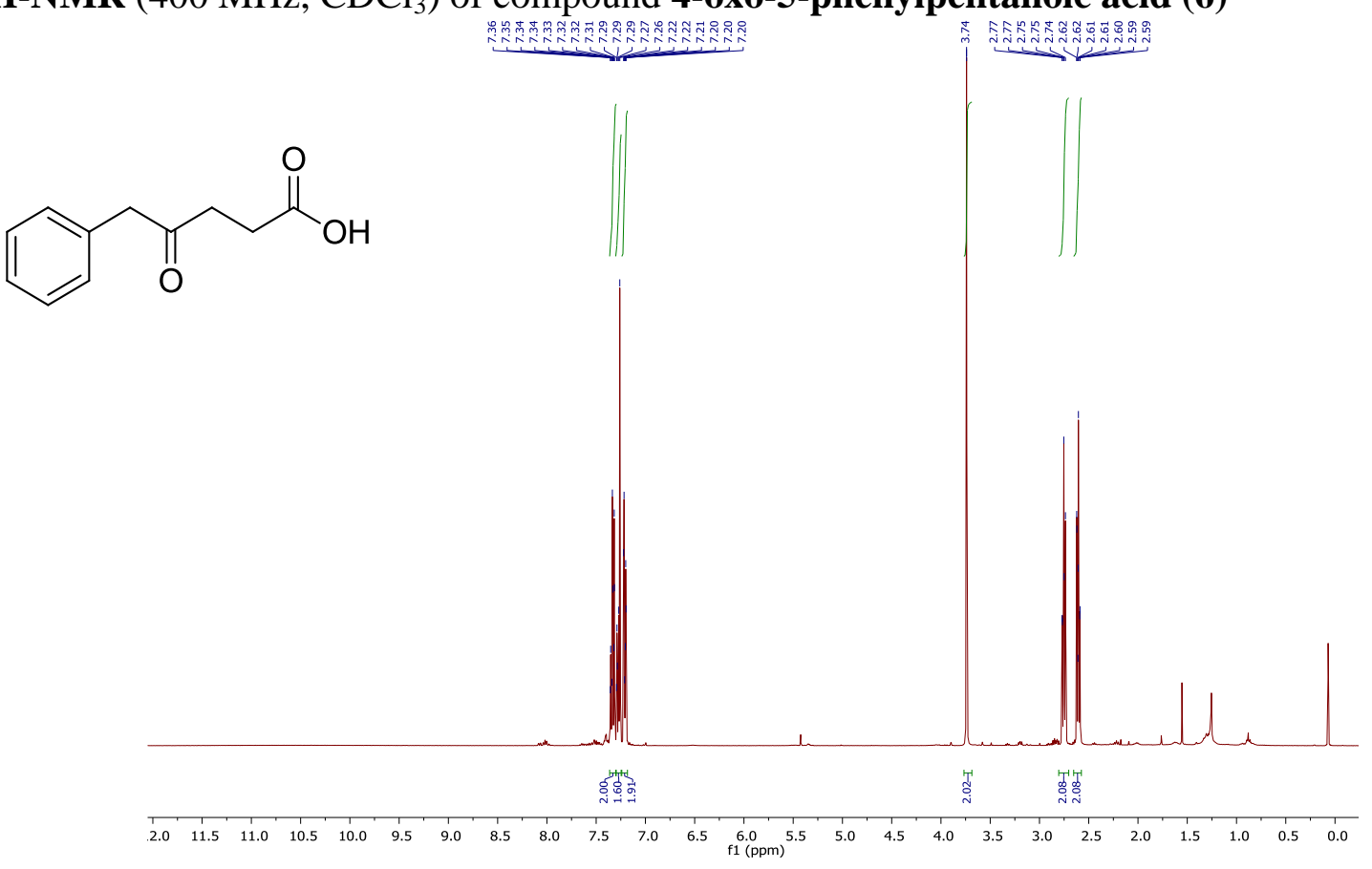

${ }^{13} \mathrm{C}-\mathrm{NMR}\left(101 \mathrm{MHz}, \mathrm{CDCl}_{3}\right)$ of compound 4-oxo-5-phenylpentanoic acid (6)<smiles>[Y][Te][Te]</smiles><smiles>O=C(O)CCC(=O)Cc1ccccc1</smiles>

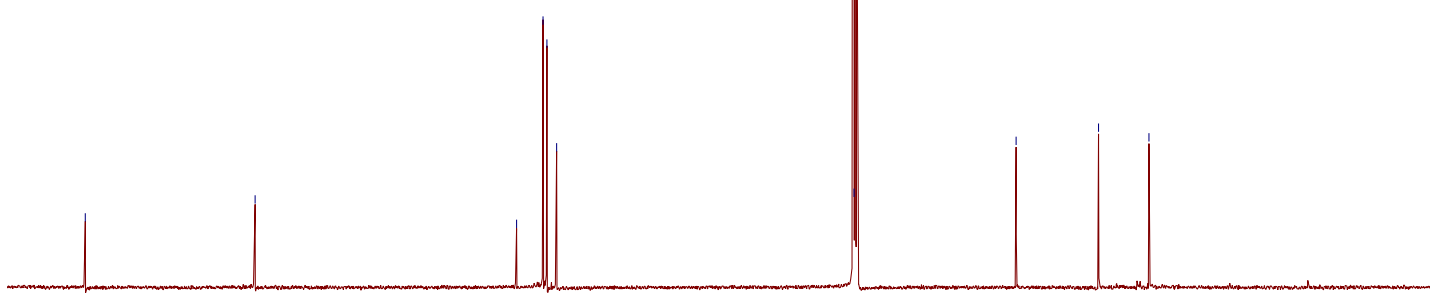

$\begin{array}{lllllllllllllllllllllllllllll}210 & 200 & 190 & 180 & 170 & 160 & 150 & 140 & 130 & 120 & 110 & 100 & 90 & 80 & 70 & 60 & 50 & 40 & 30 & 20 & 10 & 0 & -10 & \end{array}$ 
${ }^{1}$ H-NMR (400 MHz, $\mathrm{CDCl}_{3}$ ) of compound methyl 4-oxo-5-phenylpentanoate (7)

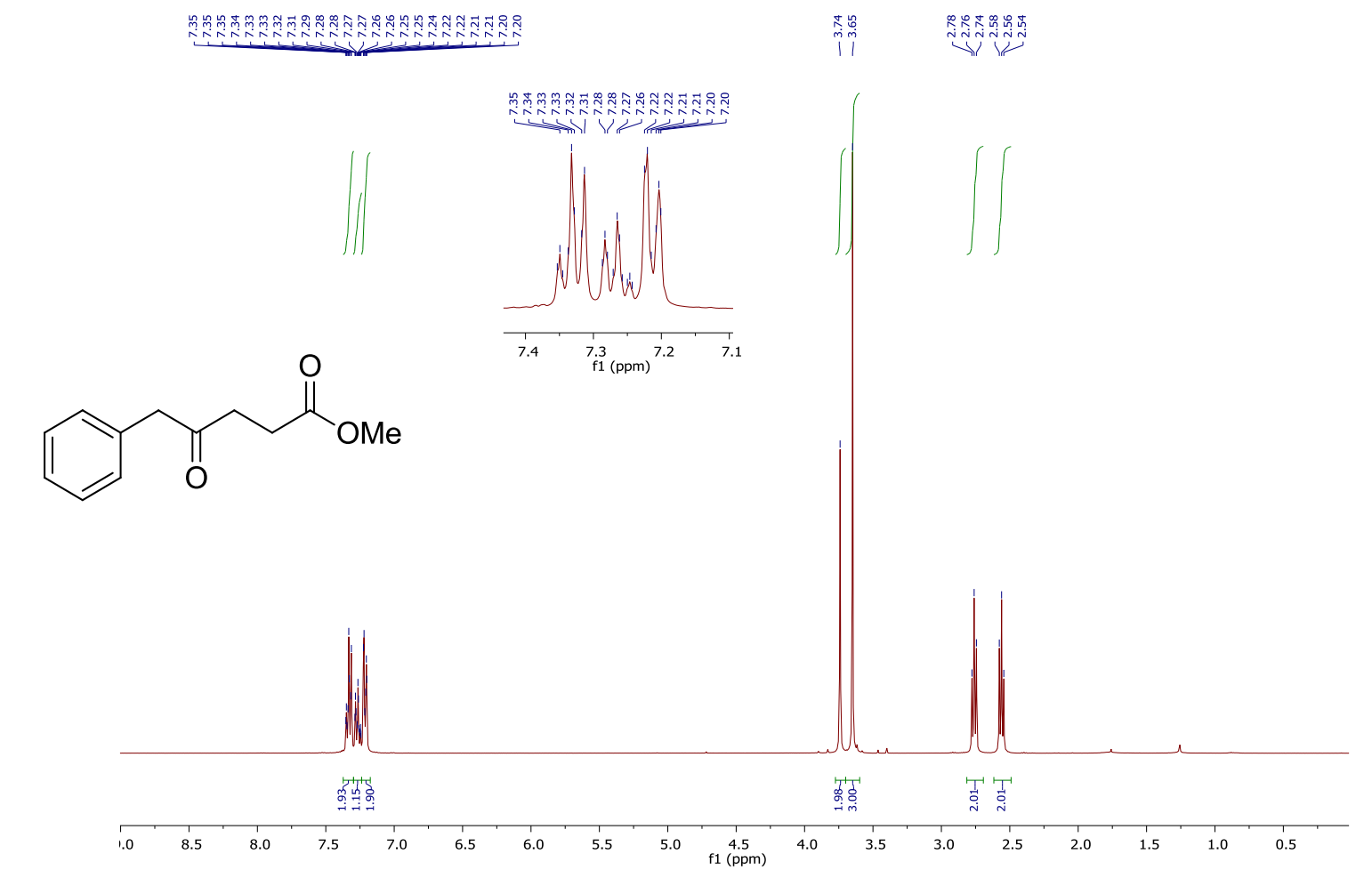

${ }^{13}$ C-NMR (101 MHz, $\mathrm{CDCl}_{3}$ ) of compound methyl 4-oxo-5-phenylpentanoate (7)

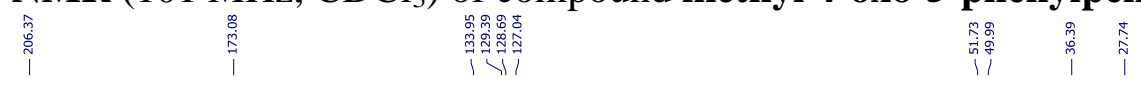<smiles>COC(=O)CCC(=O)Cc1ccccc1</smiles>

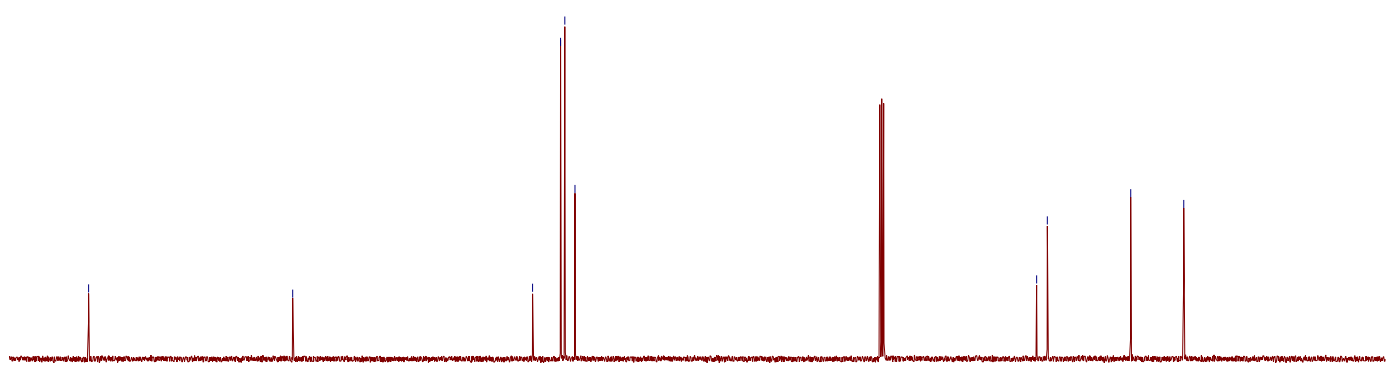


${ }^{1} \mathbf{H}-\mathrm{NMR}\left(400 \mathrm{MHz}, \mathrm{CDCl}_{3}\right.$ ) of compound 3-(4-fluorobenzyl)-3-(4-phenyl-1H-1,2,3-triazol-1yl)isobenzofuran-1(3H)-one (8)

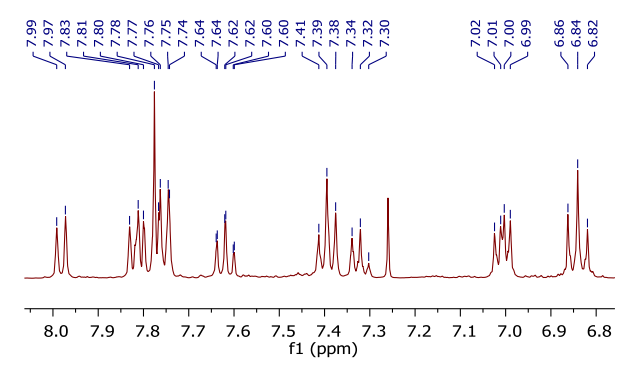<smiles>O=C1OC(Cc2ccc(F)cc2)(n2cc(-c3ccccc3)nn2)c2ccccc21</smiles>
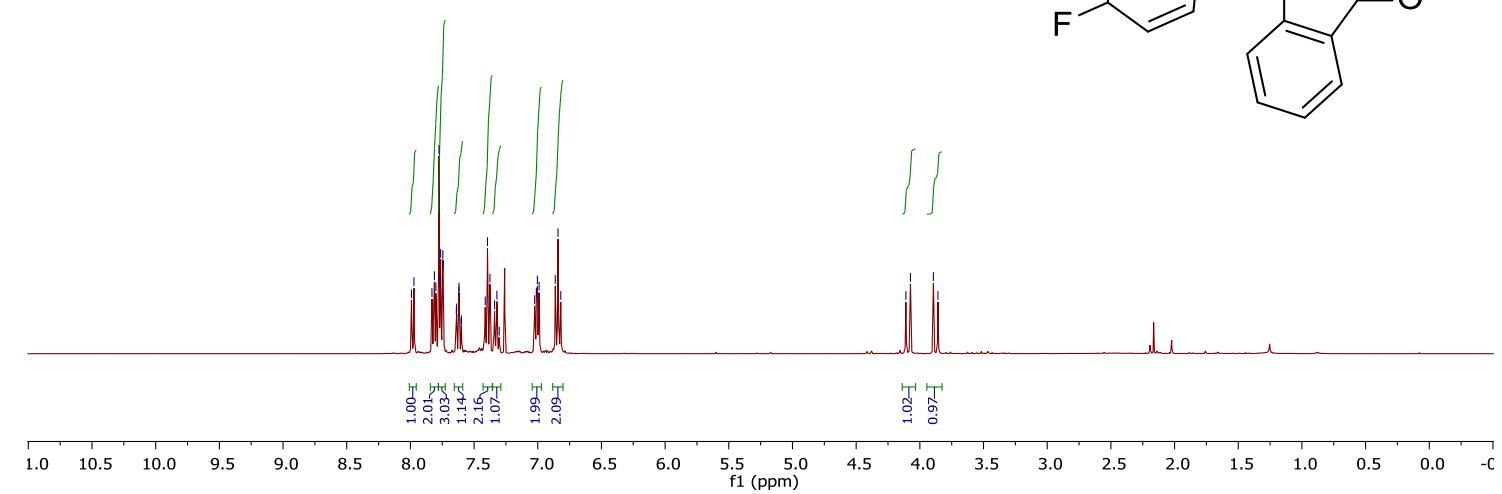

${ }^{13}$ C-NMR (101 MHz, $\mathrm{CDCl}_{3}$ ) of compound 3-(4-fluorobenzyl)-3-(4-phenyl-1H-1,2,3-triazol-1yl)isobenzofuran-1 $(3 \mathrm{H})$-one $(8)$
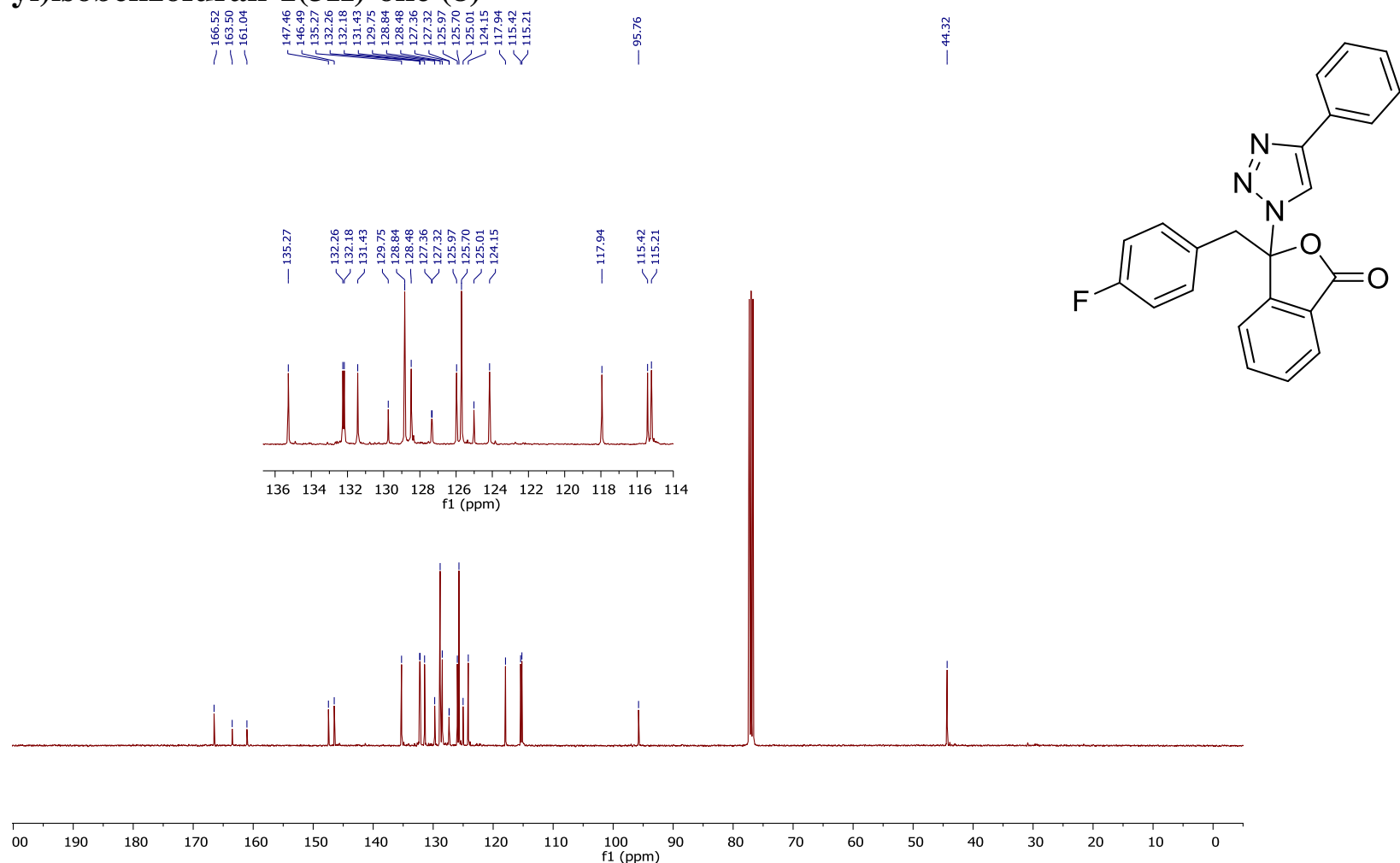
${ }^{19} \mathbf{F}$ NMR $\left(376 \mathrm{MHz}, \mathrm{CDCl}_{3}\right.$ ) of compound 3-(4-fluorobenzyl)-3-(4-phenyl-1H-1,2,3-triazol1-yl)isobenzofuran-1(3H)-one (8)<smiles>O=C1OC(Cc2ccc(F)cc2)(c2ccccc2)c2ccccc21</smiles>
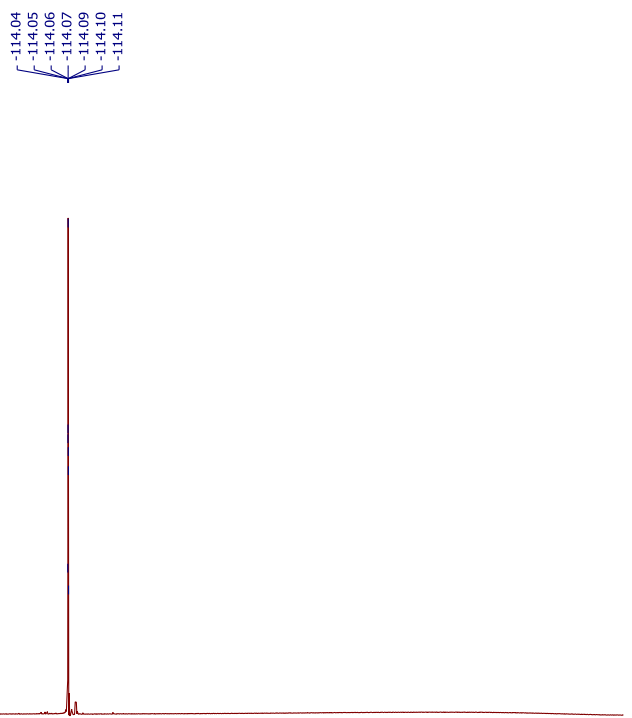

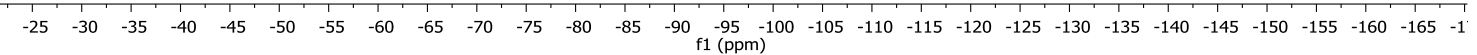

IR of compound 3-(4-fluorobenzyl)-3-(4-phenyl-1H-1,2,3-triazol-1-yl)isobenzofuran-1(3H)one (8)

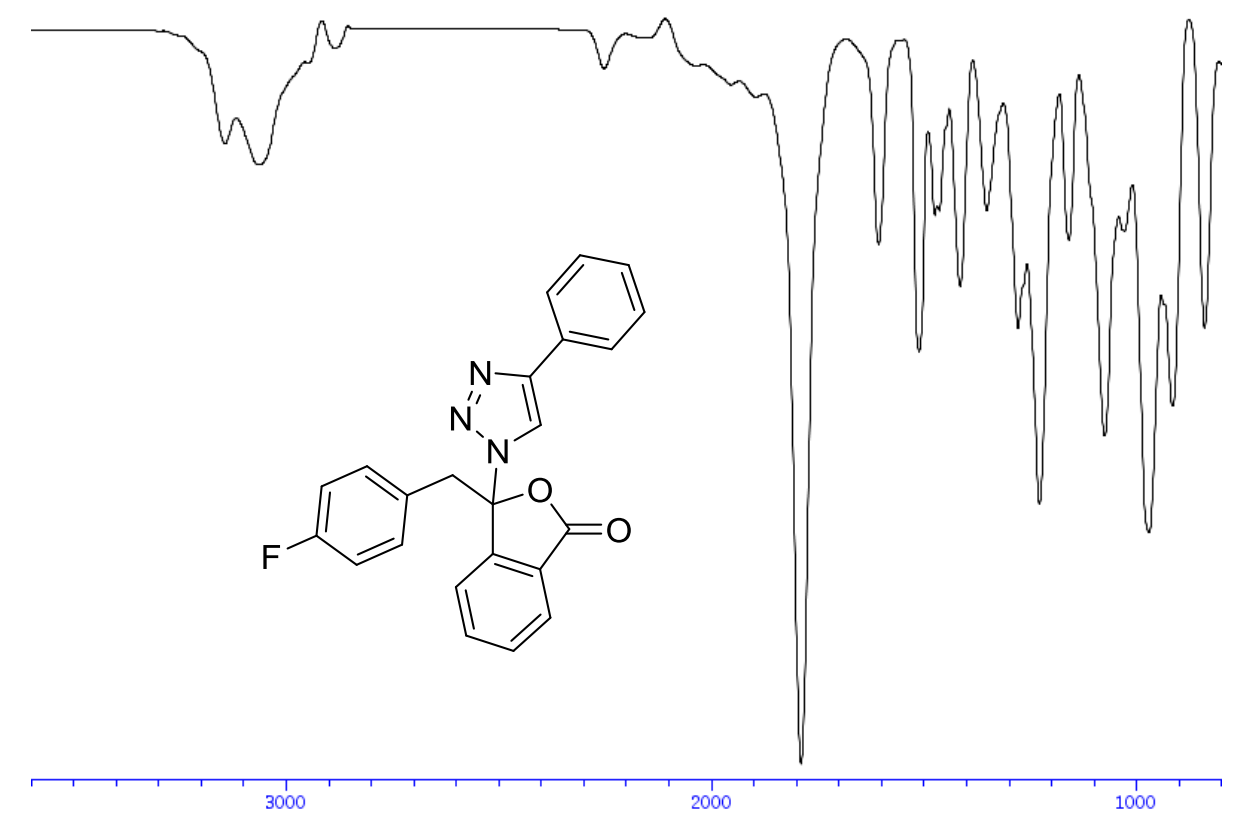


${ }^{1} \mathbf{H}-\mathrm{NMR}(400 \mathrm{MHz}, \mathrm{CDCl} 3)$ of compound 4-((tert-butoxycarbonyl)amino)-5-(4chlorophenyl)pentanoic acid (9)

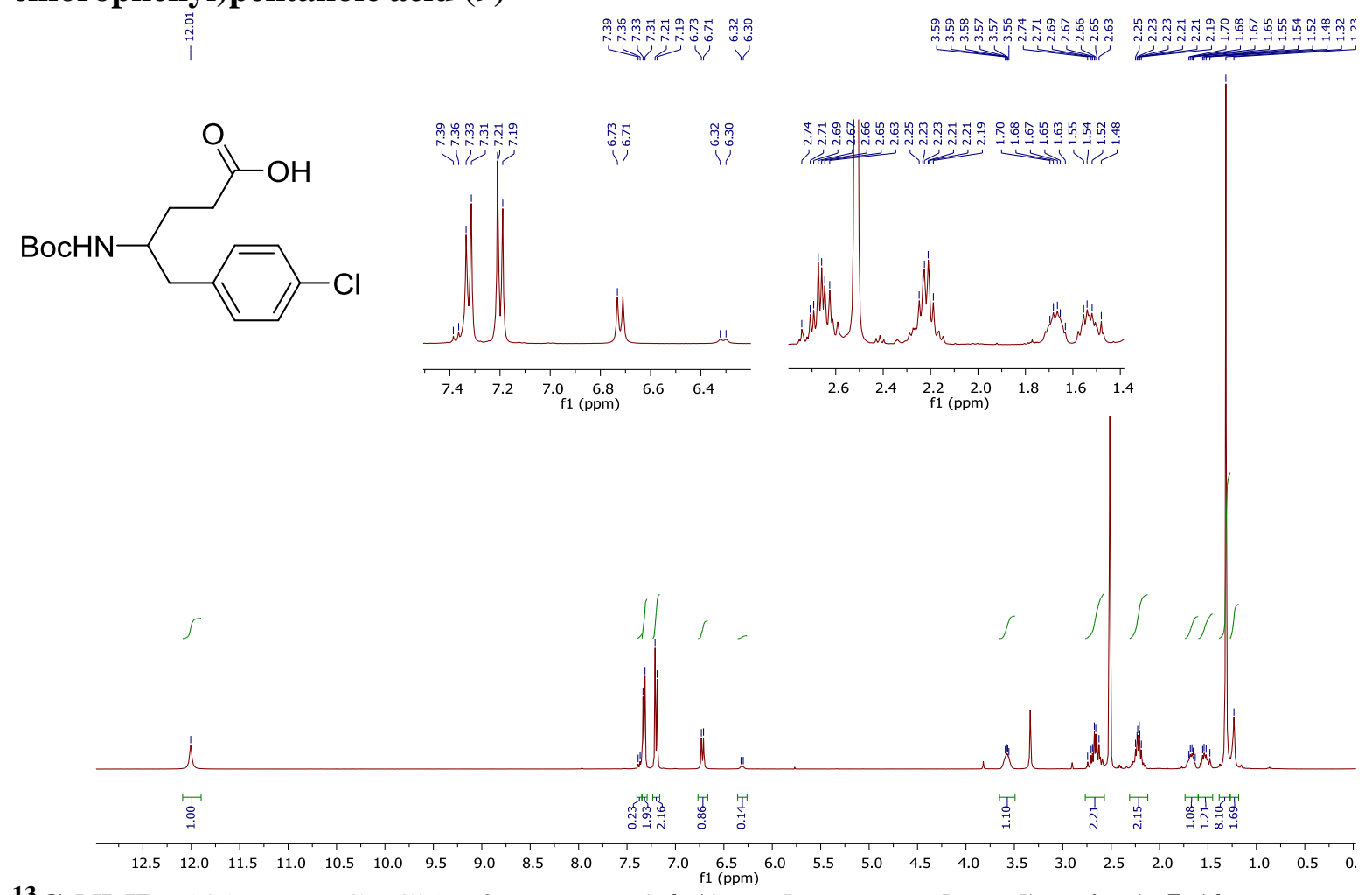

${ }^{13}$ C-NMR (101 MHz, $\mathrm{CDCl}_{3}$ ) of compound 4-((tert-butoxycarbonyl)amino)-5-(4chlorophenyl)pentanoic acid (9)

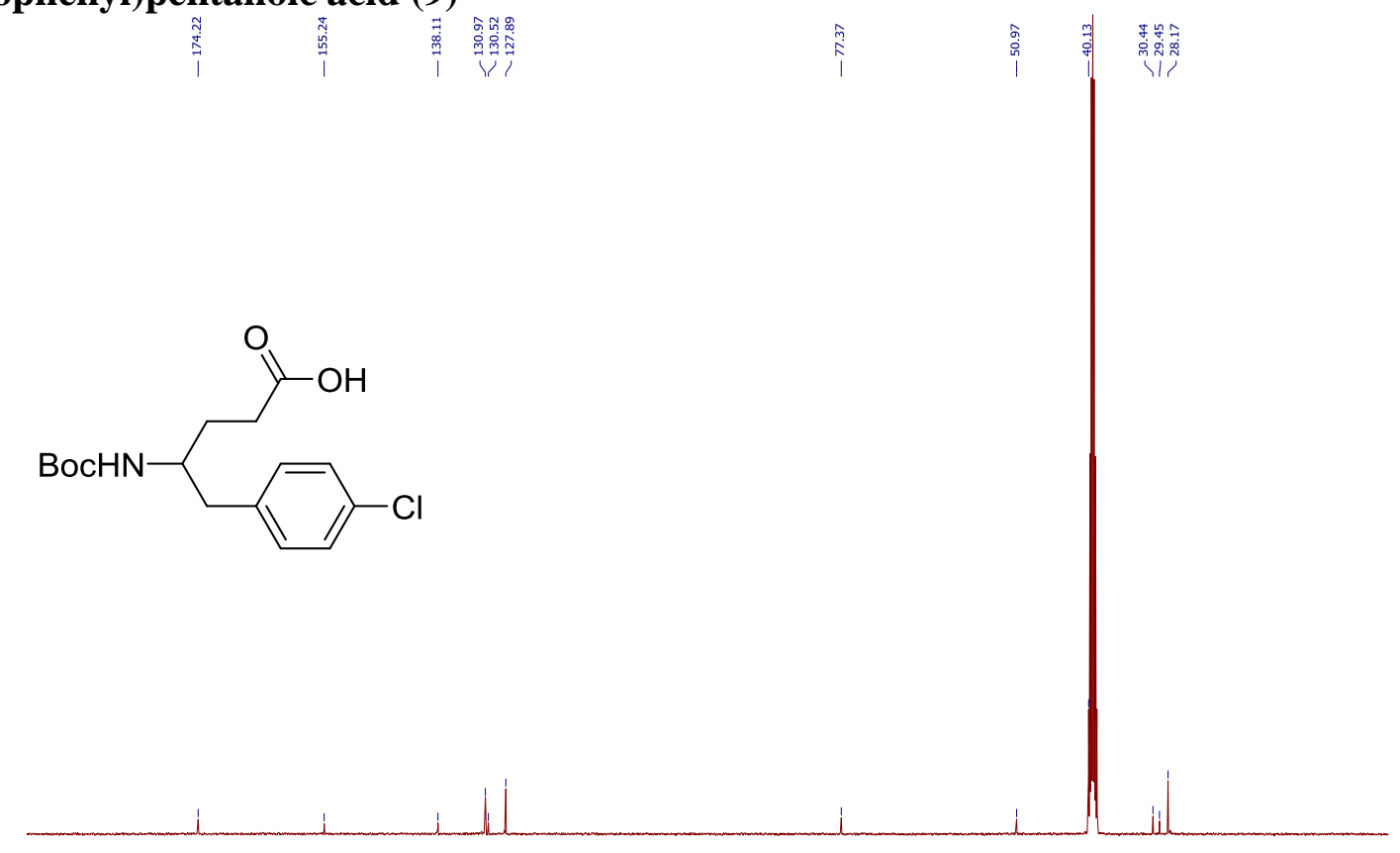

$\begin{array}{llllllllll}190 & 180 & 170 & 160 & 150 & 140 & 130 & 120 & 110 & \underset{f 1(\mathrm{ppm})}{100} 90 \\ & & & & \end{array}$ 
HSQC of compound 4-((tert-butoxycarbonyl)amino)-5-(4-chlorophenyl)pentanoic acid (9)

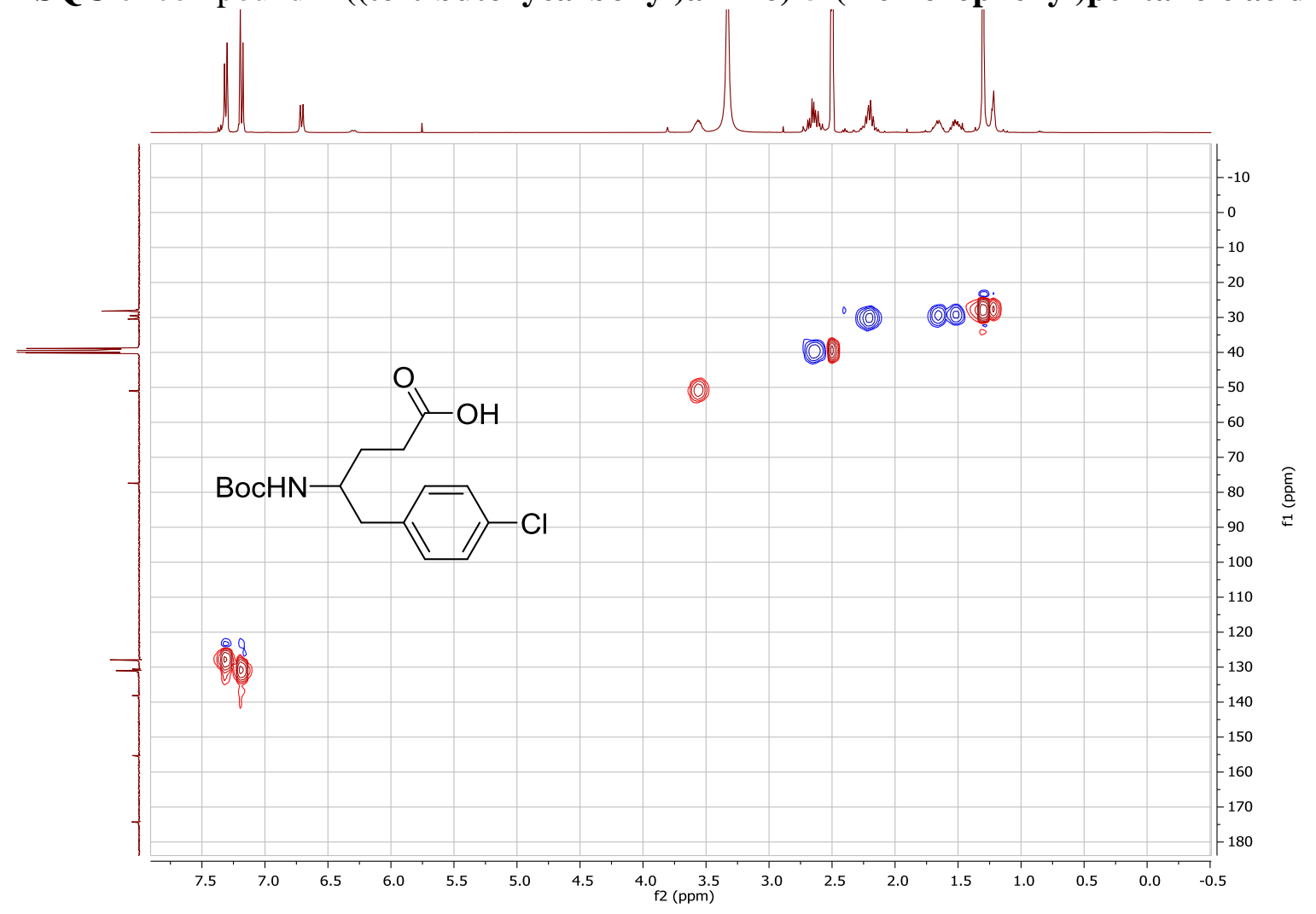

IR of compound 4-((tert-butoxycarbonyl)amino)-5-(4-chlorophenyl)pentanoic acid (9)

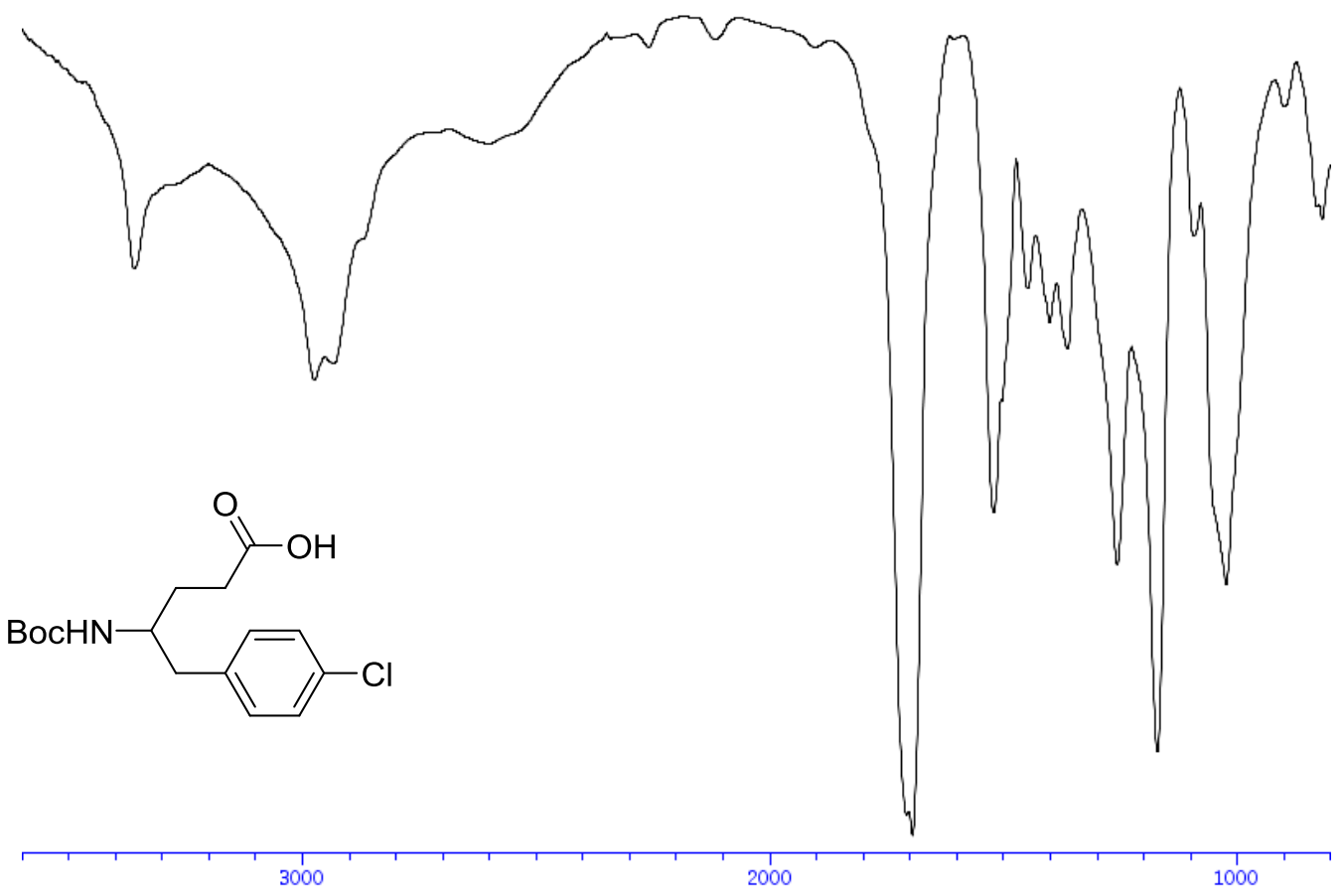


${ }^{1} \mathbf{H}-\mathrm{NMR}\left(400 \mathrm{MHz}, \mathrm{CDCl}_{3}\right.$ ) of compound 3-amino-3-(4-fluorobenzyl)isobenzofuran-1(3H)one (10)

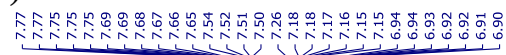
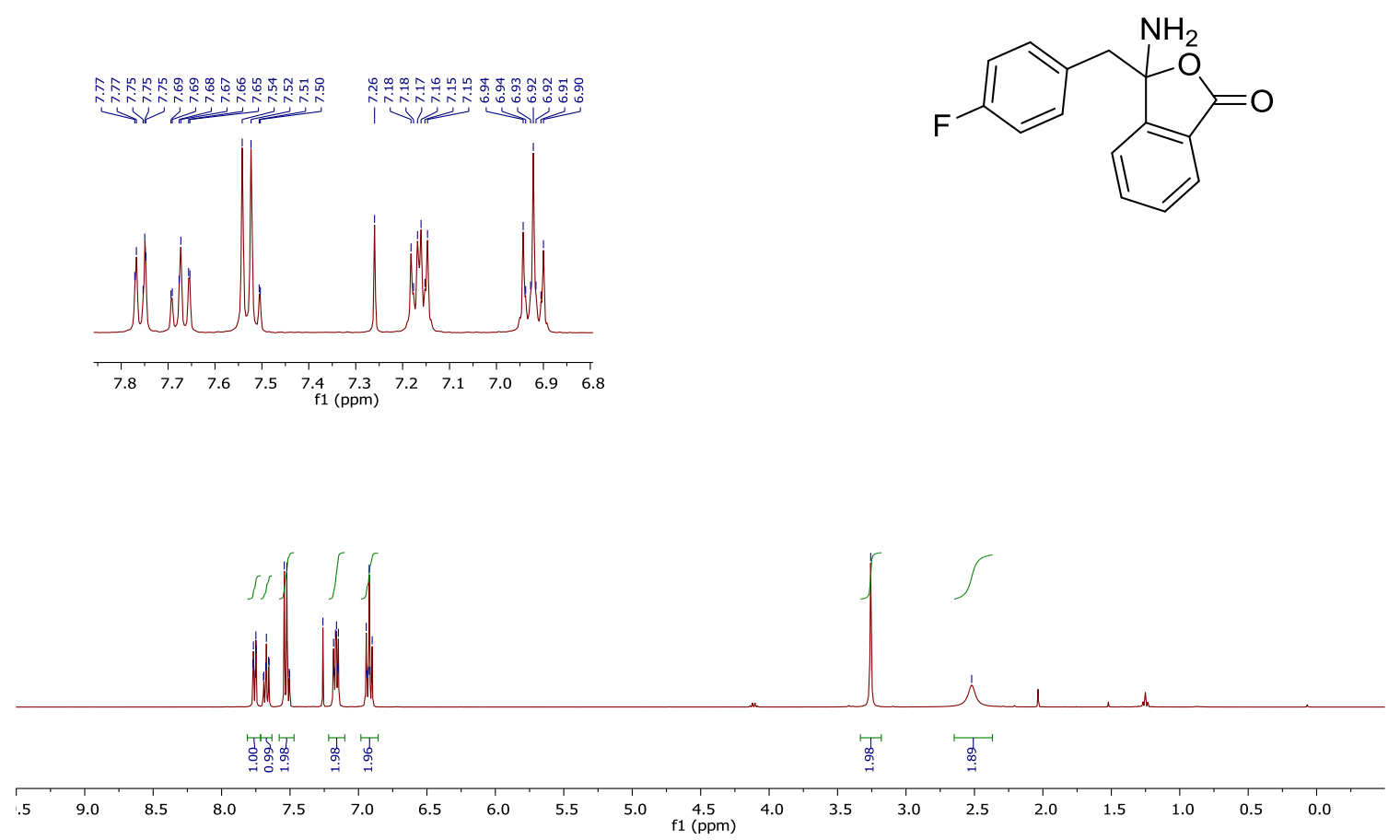

${ }^{13} \mathbf{C}-\mathbf{N M R}\left(101 \mathrm{MHz}, \mathrm{CDCl}_{3}\right.$ ) of compound 3-amino-3-(4-fluorobenzyl)isobenzofuran-1(3H)one (10)
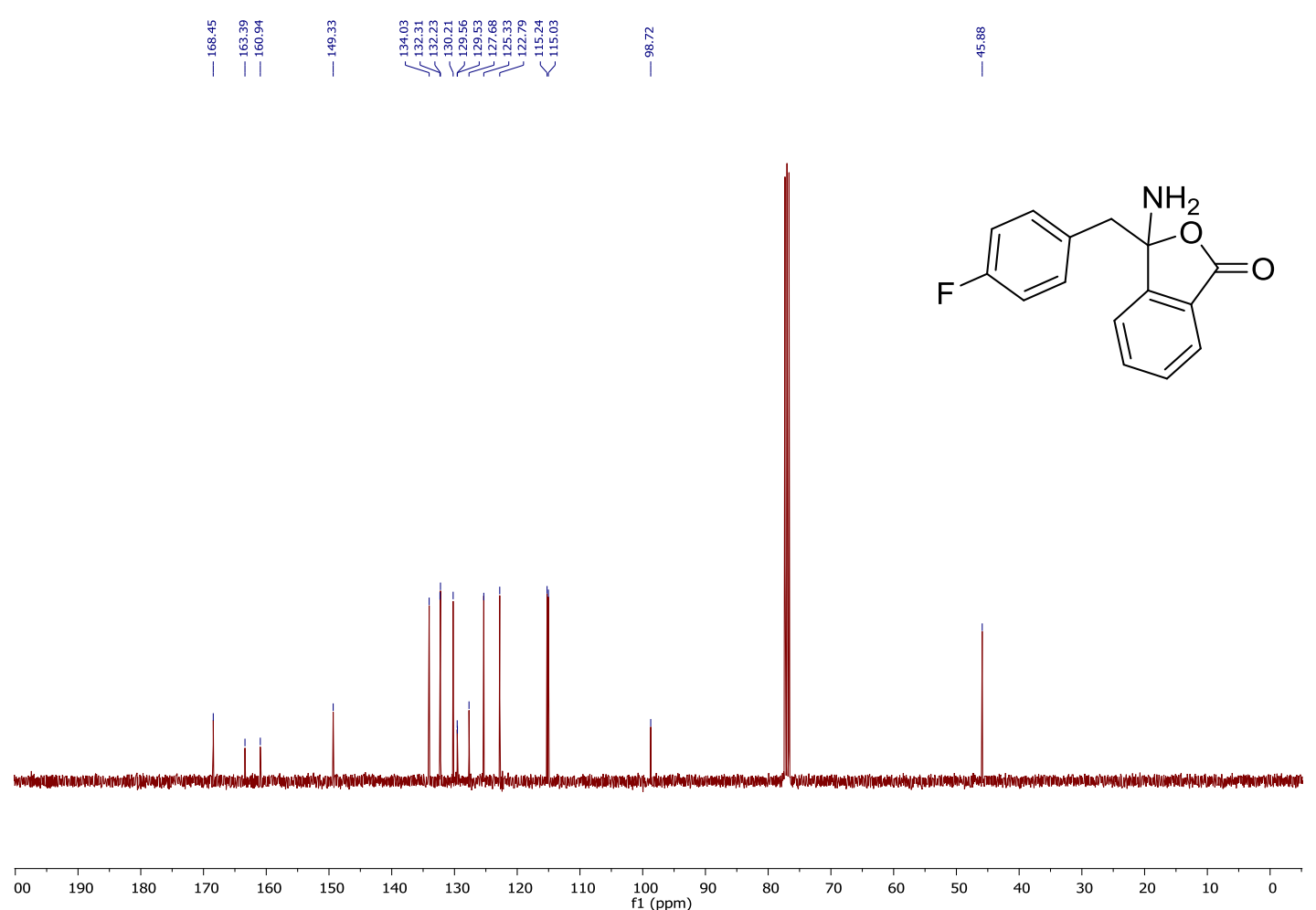
${ }^{19}$ F NMR $\left(376 \mathrm{MHz}, \mathrm{CDCl}_{3}\right)$ of compound 3-amino-3-(4-fluorobenzyl)isobenzofuran-1(3H)one (10)<smiles>NC1(Cc2ccc(F)cc2)OC(=O)c2ccccc21</smiles>

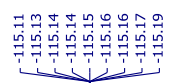

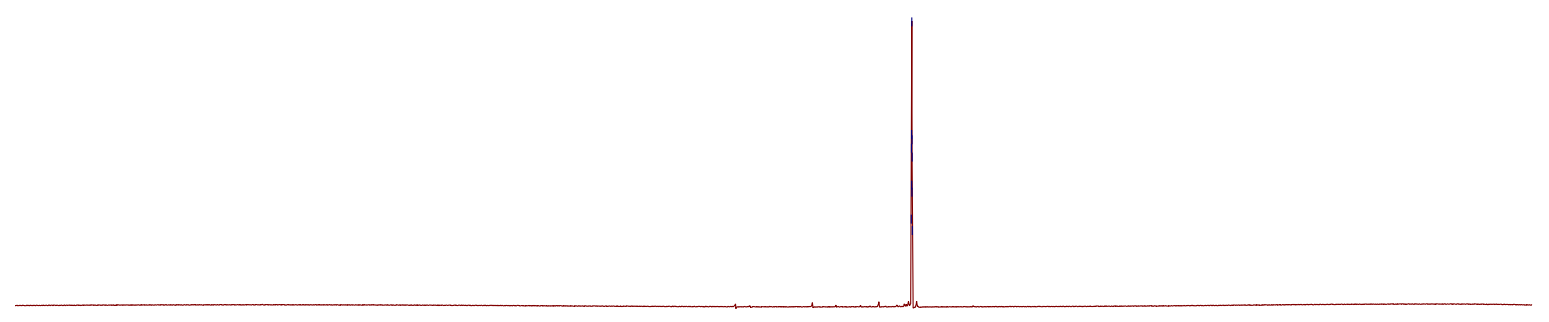

\begin{tabular}{llllllllllllllllllllllll}
\hline & -55 & -60 & -65 & -70 & -75 & -80 & -85 & -90 & -95 & -100 & $\begin{array}{c}1 \\
-105\end{array}$ & -110 & -115 & -120 & -125 & -130 & -135 & -140 & -145 & -150 & -155 & -1
\end{tabular}

IR of compound -amino-3-(4-fluorobenzyl)isobenzofuran-1(3H)-one (10)

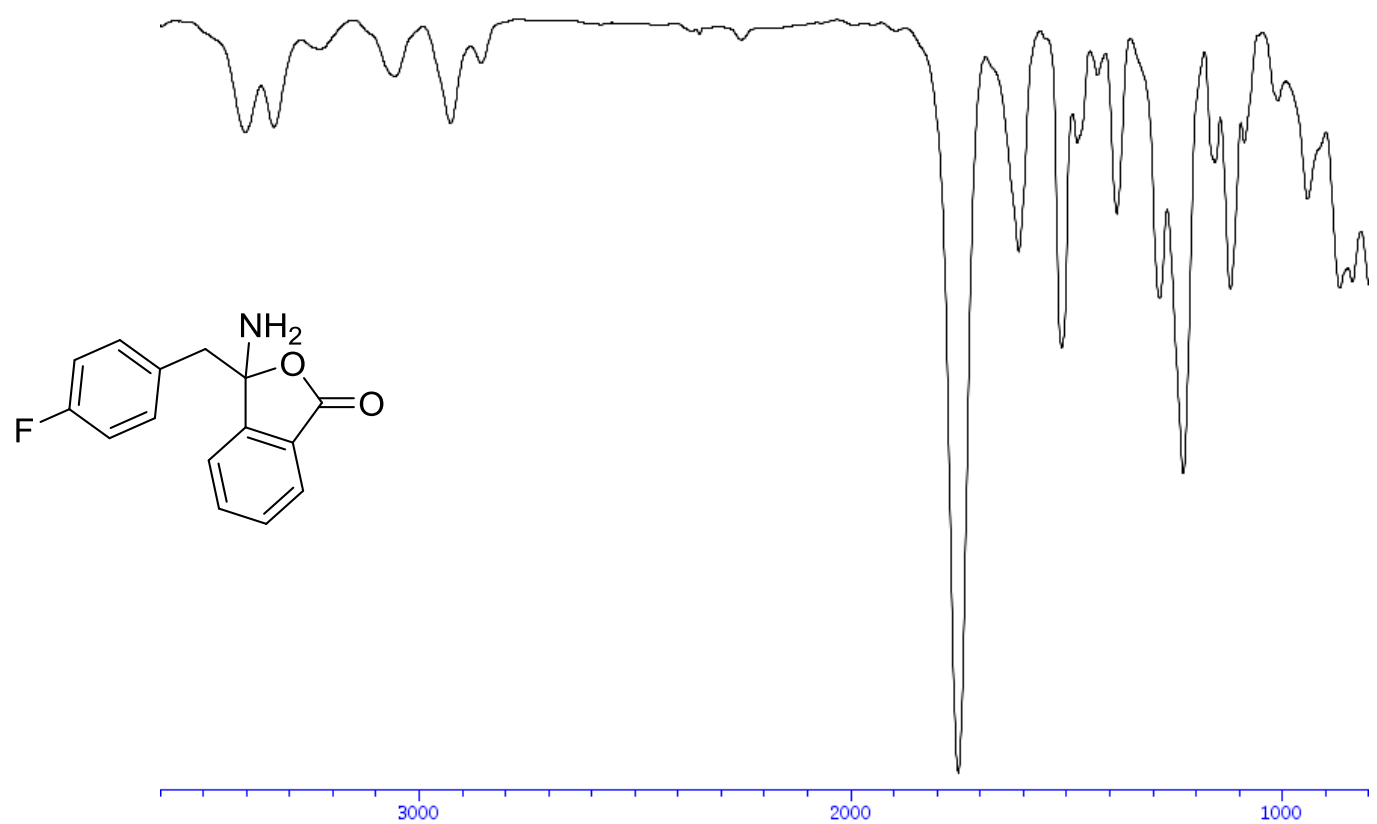




\section{References}

[1] J. P. Brand, J. Charpentier, J. Waser, Angew. Chem. Int. Ed. 2009, 48, 9346-9349.

[2] P. Eisenberger, S. Gischig, A. Togni, Chem. Eur. J. 2006, 12, 2579-2586.

[3] M. V. Vita, J. Waser, Org. Lett. 2013, 15, 3246-3249.

[4] M. V. Vita, J. Waser, Angew. Chem. Int. Ed. 2015, 54, 5290-5292.

[5] M. V. Vita, P. Caramenti, J. Waser, Org. Lett. 2015, 17, 5832-5835.

[6] N. Sakai, S. Horikawa, Y. Ogiwara, RSC Advances 2016, 6, 81763-81766.

[7] J. M. Patrick, A. T. Dafydd, S. Nina, W. R. C. Peter, P. Simon, Letters in Organic Chemistry 2010, 7, 508-510.

[8] S. E. Drewes, D. Douglass, D. G. S. Malissar, G. H. P. Roos, P. T. Kaye, J. Chem. Soc., Perkin Trans. 1 1990, 1507-1511.

[9] J. Miao, H. Ge, Org. Lett. 2013, 15, 2930-2933.

[10] B. N. Hemric, K. Shen, Q. Wang, J. Am. Chem. Soc. 2016, 138, 5813-5816.

[11] L. Zhou, C. K. Tan, X. Jiang, F. Chen, Y.-Y. Yeung, J. Am. Chem. Soc. 2010, 132, 15474-15476.

[12] Z. Ning, R. Jin, J. Ding, L. Gao, Synlett 2009, 2009, 2291-2294.

[13] G. C. Geary, E. G. Hope, A. M. Stuart, Angew. Chem. Int. Ed. 2015, 54, 14911-14914.

[14] C. B. Tripathi, S. Mukherjee, Angew. Chem. Int. Ed. 2013, 52, 8450-8453.

[15] T. Nishikata, Y. Noda, R. Fujimoto, T. Sakashita, J. Am. Chem. Soc. 2013, 135, 1637216375.

[16] T. Mukaiyama, I. Shiina, H. Iwadare, M. Saitoh, T. Nishimura, N. Ohkawa, H. Sakoh, K. Nishimura, Y.-i. Tani, M. Hasegawa, K. Yamada, K. Saitoh, Chem. Eur. J. 1999, 5, 121161.

[17] D. L. Boger, R. J. Mathvink, J. Org. Chem. 1992, 57, 1429-1443.

[18] R. Zhu, S. L. Buchwald, J. Am. Chem. Soc. 2015, 137, 8069-8077.

[19] X. Jiang, C. K. Tan, L. Zhou, Y.-Y. Yeung, Angew. Chem. Int. Ed. 2012, 51, 7771-7775.

[20] K. Murai, T. Matsushita, A. Nakamura, S. Fukushima, M. Shimura, H. Fujioka, Angew. Chem. Int. Ed. 2010, 49, 9174-9177.

[21] B. Schmidt, S. Hauke, Org. Biomol. Chem. 2013, 11, 4194-4206.

[22] K.-T. Yip, D. Yang, Org. Lett. 2011, 13, 2134-2137.

[23] Y. Chen, S. H. Park, C. W. Lee, C. Lee, Chem. Asian J. 2011, 6, 2000-2004.

[24] S. Nicolai, C. Piemontesi, J. Waser, Angew. Chem. Int. Ed. 2011, 50, 4680-4683.

[25] S. Nicolai, S. Erard, D. F. González, J. Waser, Org. Lett. 2010, 12, 384-387.

[26] M. A. Brimble, C. L. Flowers, J. K. Hutchinson, J. E. Robinson, M. Sidford, Tetrahedron 2005, 61, 10036-10047.

[27] M. Bruder, P. L. Haseler, M. Muscarella, W. Lewis, C. J. Moody, J. Org. Chem. 2010, 75, 353-358.

[28] J. E. Aho, E. Salomäki, K. Rissanen, P. M. Pihko, Org. Lett. 2008, 10, 4179-4182.

[29] R. Frei, T. Courant, M. D. Wodrich, J. Waser, Chem. Eur. J. 2015, 21, 2662-2668.

[30] C. Ketterer, B. Wünsch, Eur. J. Org. Chem. 2012, 2012, 2428-2444. 